UNIVERSIDADE DE SÃO PAULO

ESCOLA DE ENGENHARIA DE SÃO CARLOS

PROGRAMA DE PÓS-GRADUAÇÃO EM GEOTECNIA

YNAÊ ALMEIDA FERREIRA

\title{
ANÁLISE NUMÉRICA DA PERFURAÇÃo E CIMENTAÇÃO DE POÇOS DE PETRÓLEO EM EVAPORITOS
}

\author{
VERSÃO CORRIGIDA \\ ORIGINAL SE ENCONTRA DISPONÍVEL NA UNIDADE QUE ALOJA O PROGRAMA
}

São Carlos 



\section{ANÁLISE NUMÉRICA DA PERFURAÇÃO E CIMENTAÇÃO DE POÇOS DE PETRÓLEO EM EVAPORITOS} Dissertação apresentada à Escola de
Engenharia de São Carlos,
Universidade de São Paulo, como
parte dos requisitos para obtenção do
título de Mestre em Ciências,
Programa de Pós-graduação em
Geotecnia.

Área de concentração: Geotecnia

Orientador: Prof. Dr. Tarcísio Barreto Celestino

\section{VERSÃO CORRIGIDA \\ ORIGINAL SE ENCONTRA DISPONÍVEL NA UNIDADE QUE ALOJA O PROGRAMA}

São Carlos

2014 
AUTORIZO A REPRODUÇÃO TOTAL OU PARCIAL DESTE TRABALHO, POR QUALQUER MEIO CONVENCIONAL OU ELETRÔNICO, PARA FINS DE ESTUDO E PESQUISA, DESDE QUE CITADA A FONTE.

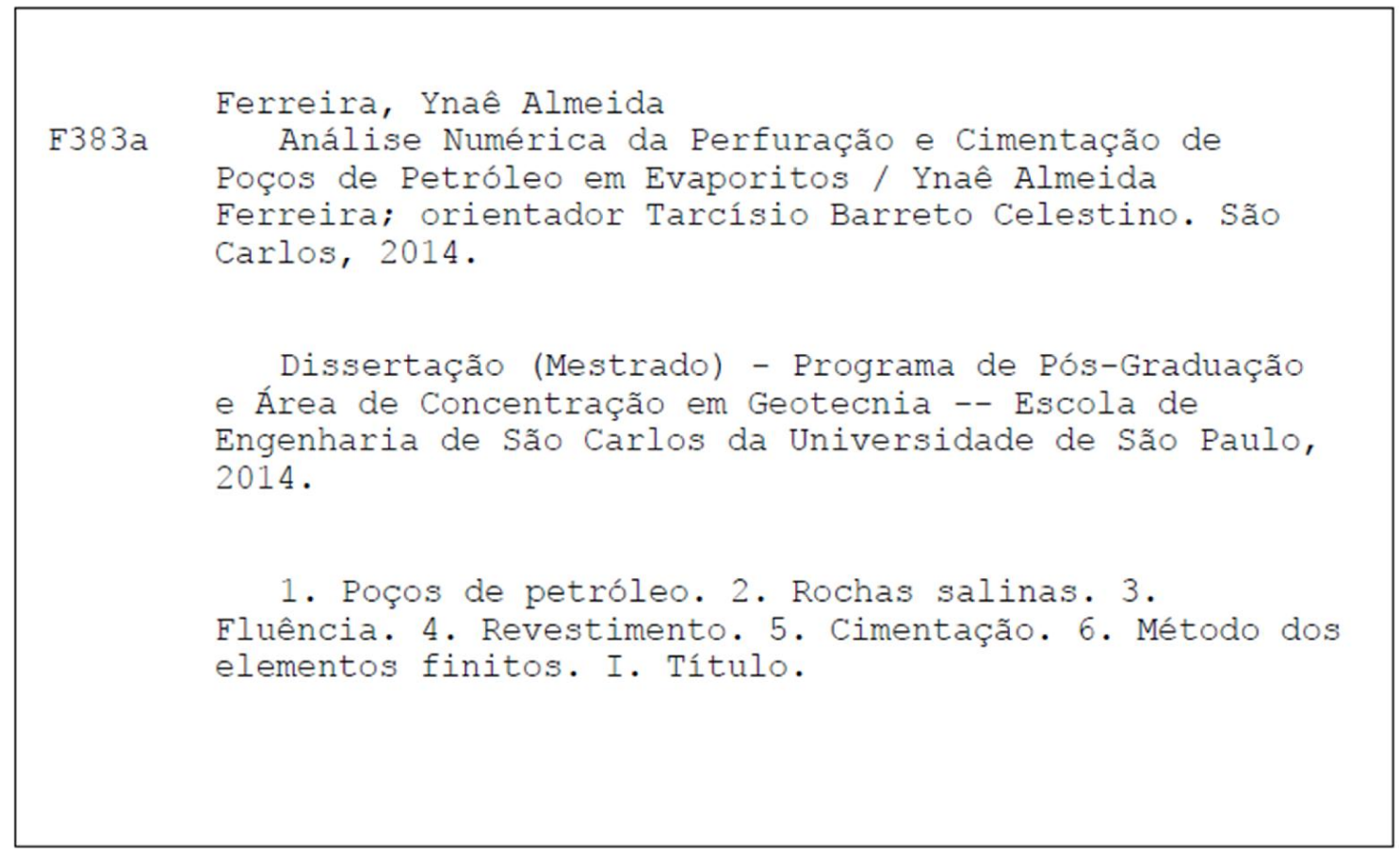




\section{FOLHA DE JULGAMENTO}

Candidata: Engenheira YNAÊ ALMEIDA FERREIRA.

Título da dissertação: "Análise numérica da perfuração e cimentação de poços de petróleo em evaporitos".

Data da defesa: 13/10/2014

Comissão Julgadora:

Prof. Dr. Tarcísio Barreto Celestino (Orientador)

(Escola de Engenharia de São Carlos/EESC)

Prof. Dr. Osvaldo Luis Manzoli

(Universidade Estadual Paulista "Júlio de Mesquita Filho"/UNESP-Bauru)

Prof. Dr. Ricardo Carrazedo

(Escola de Engenharia de São Carlos/EESC)

Coordenador do Programa de Pós-Graduação em Geotecnia:

Prof. Titular Osni José Pejon

Presidente da Comissão de Pós-Graduação:

Prof. Associado Paulo César Lima Segantine
Resultado:

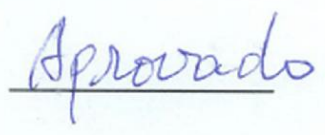

APROVARO

Aprovado 

Dedico ao meu avô Manoel Almeida Pinto (*1918 - 2014 †) por ser meu maior exemplo de como viver bem!

A ele todo meu amor e a certeza de que sua história de vida será propagada por onde quer que eu vá!!!

\section{Saudades meu voinho!!!}





\section{AGRADECIMENTOS}

Primeiramente a Deus todo poderoso por cumprir mais uma de suas promessas em minha vida. "Portanto dEle, por Ele e para Ele são todas as coisas. A Ele seja a glória perpetuamente! Amém. (Romanos 11:36)".

$\grave{A}$ minha amada mãe, por estar comigo em todos os momentos e por ser fonte de amor e paz em minha vida. À ela mais essa conquista e todo amor que eu puder lhe dar.

Aos meus irmãos Cicinho e Júnior, pelo incentivo para que eu sempre chegasse aos meus objetivos. À minha tia Marluce e minha prima Bárbara, pelo apoio e carinho em todos os passos da minha vida.

Ao meu amado noivo Jademilson, por estar sempre ao meu lado, me apoiando e me amando. Obrigada por todo companheirismo e paciência.

À toda minha família, em especial aos meus tios Antônio, Cicinha, Luzineide, Elias, Michelle, Marileide e aos meus primos, que em seu inesgotável apoio me guiaram para mais uma grande conquista.

Ao Prof. Dr. Tarcísio Barreto Celestino, pelos ensinamentos, incentivo e apoio, fundamentais no desenvolvimento desse trabalho.

Ao Prof. Dr. Antônio Airton Bortolucci, pela orientação no Programa de Aperfeiçoamento ao Ensino (PAE) durante a monitoria da disciplina Mecânica das Rochas.

A todos os professores, técnicos e funcionários do departamento de Geotecnia, em especial ao Prof. Dr. Orencio Monje Vilar, por sua supervisão durante o estágio nos laboratórios do departamento em 2010 e por todo incentivo e apoio durante a realização da pesquisa.

A todos os colegas do departamento, em especial Isabela Monici, Camila Almeida, Lígia Sampaio, Maria Paula, Juliana Jovanini e aos amigos do Laboratório de Mecânica das Rochas, Patrícia Saavedra, Paola Arab, Gian Franco, Fernando Jamal e 
nosso técnico Benedito.

Aos pesquisadores que mesmo à distância contribuíram com a realização desse trabalho, Cagri Mollamahmutoglu da University of Texas at Dallas e Giovanny Diaz da Pontificia Universidad Católica de Valparaíso.

A todos os amigos da Primeira Igreja Batista de São Carlos, em especial ao Pastor Jarbas e irmã Lucy, Marcelo e Amanda Eler, Danilo e Juliana Eler, Débora, Simei, Leo Christino, Leo Medrano, Leo Peres, Bruno Colosi, Olibário Neto, Daniel Lima, Daniel Araújo, Henrique e Aline, Egnaldo, Jarbinhas e Martinha, Roberta e João, Naiara, Noeli, Meirielly e Fernando Zuher.

Aos professores e amigos do Centro de Tecnologia (CTEC) da Universidade Federal de Alagoas e do antigo Centro Federal de Educação Tecnológica de Alagoas CEFET/AL (atual Instituto Federal de Alagoas - IF/AL), em especial ao Heleno Pontes, Débora Assis, Ketson Roberto, Emerson Acácio, Gregório Ferreira, Maria Helynne, Eliúdes, Luana Barbosa, Karoline Mendonça, Cirlaine e Daniel Hugo.

À Escola de Engenharia de São Carlos da Universidade de São Paulo, pela bolsa concedida durante a participação no Programa de Aperfeiçoamento ao Ensino $(P A E)$.

Ao CNPq, pelo apoio financeiro.

$\grave{A}$ todas as pessoas, que colaboraram de forma direta ou indireta para que esse trabalho tenha sido realizado, ofereço um enorme agradecimento. 
"Minha vida é andar por esse pais Pra ver se um dia descanso féliz

Guardando as recordaçōes

Das terras onde passei

Andando pelos sertoes

Edos amigos que lá deixei

Chuva e sol

Poeira e carvão

Longe de casa

Sigo o roteiro

Mais uma estação

Ea alegria no coração..."

Luiz Gonzaga 



\section{RESUMO}

FERREIRA, Y. A. Análise numérica da perfuração e cimentação de poços de petróleo em evaporitos. 2014. 187 f. Dissertação (Mestrado) - Escola de Engenharia de São Carlos, Universidade de São Paulo, São Carlos, 2014.

Os hidrocarbonetos são encontrados sob alta pressão em rochas porosas, denominadas rochas reservatório. A camada pré-sal apresenta rochas reservatório cobertas por uma camada impermeável de sal de grande espessura. Ocorrências de estruturas salinas são favoráveis para o aprisionamento dos hidrocarbonetos e aumentam a probabilidade de sucesso na prospecção de óleo e gás, pois são excelentes rochas capeadoras, de porosidade e permeabilidade praticamente nulas. As rochas salinas apresentam deformação lenta e contínua quando submetidas a tensões constantes, fenômeno conhecido como fluência. Durante a perfuração de poços através de espessas camadas de sal podem ocorrer problemas operacionais, como o aprisionamento da coluna de perfuração e o colapso do poço. Ainda, a fluência pode levar ao colapso os revestimentos de um poço de petróleo revestido. Estes contratempos geram grandes desafios e criam oportunidades de evolução na indústria do petróleo. Neste contexto, este trabalho consiste na análise numérica da escavação de poços em rochas salinas para exploração de petróleo, com o estudo do comportamento geomecânico do sal utilizando o programa de elementos finitos Abaqus ${ }^{\circledR}$. O efeito da fluência do sal durante e após a perfuração e cimentação dos poços foi verificado utilizando diferentes pesos de fluido de perfuração, simulado como não penetrante. Análises dos deslocamentos, deformações e tensões na parede do poço e em sua vizinhança foram realizadas por meio de análises de deformação plana e análises axissimétricas. Após a instalação do revestimento e cimentação do poço que engloba tanto o processo de endurecimento do cimento, quanto a resposta de fluência da camada de sal, pôde-se analisar os deslocamentos, deformações e o comportamento das tensões na fronteira sal-cimento, evitando possíveis intervenções em poços que acarretam perdas econômicas. Sendo assim, este estudo auxilia no monitoramento e controle do fechamento de poços de petróleo em evaporito, após a escavação e cimentação do poço, evitando os diversos problemas decorrentes do comportamento de fluência do sal.

Palavras-chave: Poços de petróleo. Rochas salinas. Fluência. Revestimento. Cimentação. Método dos elementos finitos. 



\begin{abstract}
FERREIRA, Y. A. Numerical analysis of petroleum well drilling and cementing in evaporite. 2014. 187 f. MSc. Thesis - São Carlos Engineering School, University of São Paulo, São Carlos, 2014.

Hydrocarbons are found under high pressure in porous rocks, called reservoir rocks. The presalt layer shows reservoir rock covered by an impermeable salt thick layer. Occurrences of salt structures are favorable for trapping of hydrocarbons and increase the probability of success in oil and gas prospecting. They are excellent cap rocks with porosity and permeability practically nil. Salt rock present creep when subjected to continuous and constant stress. During well drilling through thick salt layers operational problems may occur like the imprisonment of the drill string and the collapse of the well. Also, creep may cause the collapse of the well casing. These setbacks create great challenges and opportunities for the evolution of the oil industry. In this context, this work proposes the numerical analysis of well excavation in salt rock for oil exploration with the study of the geomechanical behavior of salt using a finite element method (FEM) software Abaqus ${ }^{\circledR}$. The effect of salt creep during and after drilling and cementing of wells was verified using different weights of the drilling fluid assumed to be non-penetrable with respect to the wellbore formation. Analysis of displacements, strains and stresses on the face of the wellbore and into the salt formation were performed with plane strain and axisymmetric techniques. After installation of the well casing, cementing is simulated encompassing cement hardening as well as salt creep. It was possible to analyze displacements, strains and the behavior of the stress interactions between the existing boundary cement-salt formation, avoiding possible unnecessary workover operations that cause economical losses. Thus, this study assists in the control and monitoring of closing oil wells in evaporite, after excavation and cementing the well, avoiding many problems stemming from the behavior creep of salt.
\end{abstract}

Keywords: Oil well. Evaporite. Creep. Casing. Cementing. Finite elements method. 



\section{LISTA DE FIGURAS}

Figura 2-1 - Camada evaporítica, sem escala informada. 42

Figura 2-2 - Estilos de intrusão do sal: (a) Passiva - nenhum problema de espaço; (b) Ativa - espaço criado por diápiro; (c) Reativa - espaço criado por extensão........ 44

Figura 2-3 - Relações entre rochas geradoras, reservatório e selantes. ............................. 45

Figura 2-4 - Depósitos globais de sais indicados pelas áreas brancas. ............................. 46

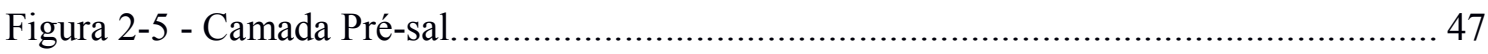

Figura 2-6 - Formação do petróleo do pré-sal no Brasil: (a) Supercontinente Gondwana; (b) Grandes lagos originados do afastamento das placas tectônicas; (c) Invasão de água salgada do mar; (d) Configuração adequada para a formação de campos de petróleo e; (e) Formação completa do Atlântico Sul e bacias brasileiras.

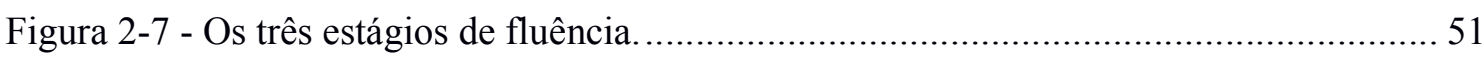

Figura 2-8 - Ensaio de fluência de um material viscoso: comportamento típico................... 52

Figura 2-9 - Modelos Básicos: (a) Modelo de Hooke; e (b) Modelo de Newton.................... 59

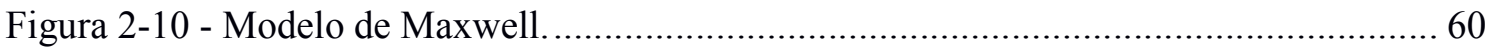

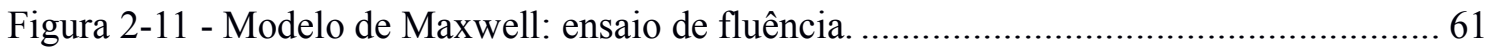

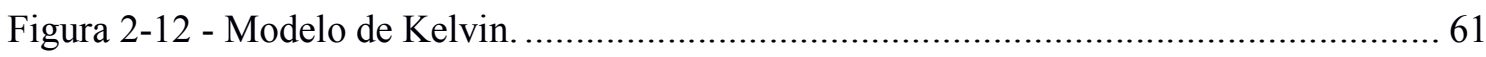

Figura 2-13 - Modelo de Kelvin: ensaio de fluência. ................................................... 63

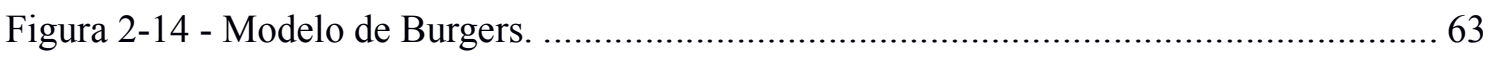

Figura 2-15 - Modelo de Burgers: ensaio de fluência................................................... 65

Figura 2-16 - Plataformas (da esquerda para direita): fixa, autoelevável,

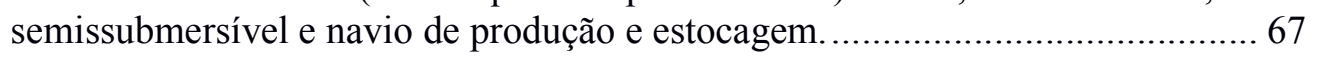

Figura 2-17 - Modelo esquemático: representação da seção transversal de um poço, mostrando o preenchimento do espaço anular com cimento. ............................. 70

Figura 2-18 - Esquema do revestimento de poços de petróleo....................................... 72

Figura 2-19 - Objetivos da cimentação primária........................................................ 74

Figura 2-20 - Esquema ilustrativo de poço com falha na cimentação................................ 75

Figura 2-21 - Perfuração em rochas salinas: possíveis problemas. ..................................... 79 
Figura 2-22 - Alargamento excessivo na parede do poço devido à dissolução do sal. ............ 80

Figura 2-23 - Batentes formados ao longo da perfuração devido à dissolução da halita......... 81

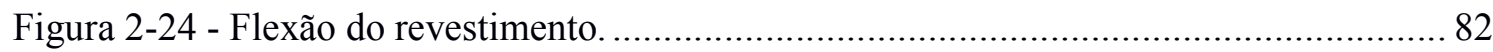

Figura 2-25 - Carregamento não linear no revestimento causado pelo movimento do sal...... 82

Figura 3-1 - Perfil geológico analisado, fora de escala................................................. 90

Figura 3-2 - Representação da seção analisada: (a) modelo plano de deformação em laranja, sem escala. As dimensões não cotadas são infinitas de acordo com a indicação das setas para baixo e para cima; (b) modelo axissimétrico em

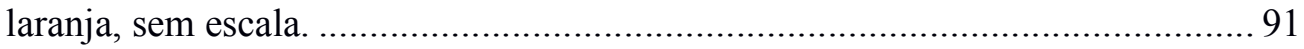

Figura 3-3 - Representação da geometria e das condições de contorno, sem escala.............. 94

Figura 3-4 - Tensões ao redor do furo circular - solução de Kirsch. .................................. 98

Figura 3-5 - Solução elástica: Kirsch (1898) versus Abaqus ${ }^{\circledR}$ : tamanho de malha $10 \mathrm{x}$

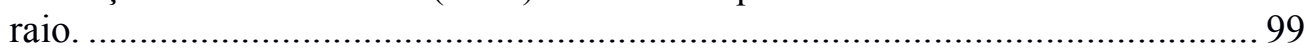

Figura 3-6 - Solução elástica: Kirsch (1898) versus Abaqus®: tamanho de malha 20 x

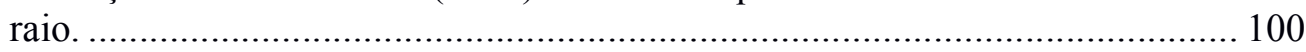

Figura 3-7 - Solução elástica: Kirsch (1898) versus Abaqus®: tamanho de malha 35 x

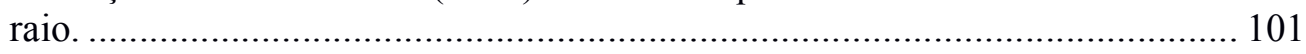

Figura 3-8 - Solução elástica: Bradley (1979) versus Abaqus ${ }^{\circledR}$ : tamanho de malha $10 \mathrm{x}$

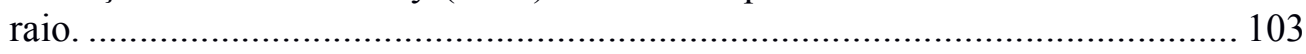

Figura 3-9 - Solução elástica: Bradley (1979) versus Abaqus®: tamanho de malha $20 \mathrm{x}$ raio.

Figura 3-10 - Solução elástica: Bradley (1979) versus Abaqus ${ }^{\circledR}$ : tamanho de malha $35 \mathrm{x}$ raio.

Figura 3-11 - Vista geral da malha de elementos finitos utilizada na simulação numérica da perfuração do poço.

Figura 3-12 - Detalhe da região próxima ao poço em destaque na Figura 3-11, com a representação do nó de análise na parede do poço. 106

Figura 3-13 - Fechamento do poço para os diferentes pesos do fluido de perfuração em um período de 30 dias.

Figura 3-14 - Fechamento do poço para os diferentes pesos do fluido de perfuração em um período de 1 dia.

Figura 3-15 - Deslocamento radial ao redor do poço para os diferentes pesos do fluido de perfuração em um período de 30 dias. 109 
Figura 3-16 - Fechamento do poço para os diferentes pesos do fluido de perfuração considerando: solução elástica, solução elástica e fluência em 1 dia e em 30 dias.

Figura 3-17 - Deslocamento em metros no sentido do eixo 1 após o período de um mês de fluência: (a) vista geral dos deslocamentos; (b) zoom na região ao redor do poço.

Figura 3-18 - Deformações radiais na parede do poço em um período de 30 dias, para os diferentes pesos do fluido de perfuração.

Figura 3-19 - Deformações radiais na parede do poço em um período de 1 dia, para os diferentes pesos do fluido de perfuração.

Figura 3-20 - Deformação radial para os diferentes pesos do fluido de perfuração considerando: solução elástica, solução elástica e fluência em 1 dia e em 30 dias.

Figura 3-21 - Deformações no sentido do eixo 1 após o período de um mês de fluência: (a) vista geral das deformações; (b) zoom na região ao redor do poço. Para obter os valores em porcentagem, deve-se multiplicar os resultados apresentados pelo Abaqus ${ }^{\circledR}$ por 100 .

Figura 3-22 - Tensões ao redor do poço considerando apenas a solução elástica, para os diferentes pesos do fluido de perfuração.

Figura 3-23 - Tensões ao redor do poço em um período de 1 dia de fluência, para os diferentes pesos do fluido de perfuração.

Figura 3-24 - Tensões ao redor do poço em um período de 30 dias de fluência, para os diferentes pesos do fluido de perfuração.

Figura 3-25 - Tensões radiais ao redor do poço em kPa após a etapa geostática.

Figura 3-26 - Tensões radiais ao redor do poço em kPa após um período de um mês de fluência.

Figura 3-27 - Detalhe da região próxima ao poço em destaque na Figura 3-26, com a representação das tensões radiais em $\mathrm{kPa}$, após um período de um mês de fluência.

Figura 3-28 - Representação das condições de contorno, sem escala.

Figura 3-29 - Estágios para a escavação do poço de petróleo em evaporito.

Figura 3-30 - Dimensões analisadas para o modelo axissimétrico, sem escala: (a) Modelo 1; (b) Modelo 2; (c) Modelo 3 e; (d) Modelo 4

Figura 3-31 - Análise das dimensões para o modelo axissimétrico. 124

Figura 3-32 - Análise do refinamento para o modelo axissimétrico. 126 
Figura 3-33 - Gráfico comparativo dos deslocamentos radiais obtidos pela solução

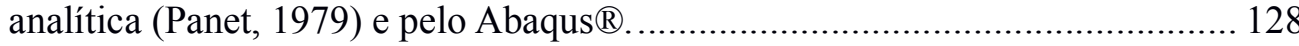

Figura 3-34 - Malha de elementos finitos utilizada na simulação numérica: (a) vista geral da malha; (b) detalhe da região a ser escavada, já com a realização da escavação do primeiro estágio (2 metros); (c) destaque em um nó de análise na parede do poço no meio do sexto estágio de escavação.

Figura 3-35 - Fechamento do poço para os diferentes pesos do fluido de perfuração em um período de 30 dias após a última escavação.

Figura 3-36 - Fechamento do poço para os diferentes pesos do fluido de perfuração em um período de 1 dia após a última escavação.

Figura 3-37 - Fechamento do poço para os diferentes pesos do fluido de perfuração considerando: solução elástica, solução elástica e fluência em 1 dia e em 30 dias, após a última escavação.

Figura 3-38 - Deslocamento em metros no sentido do eixo 1 depois de 30 dias: (a) vista geral dos deslocamentos; (b) zoom na região ao redor do poço próxima a cota 6011 abaixo do nível do mar.

Figura 3-39 - Deformações radiais na parede do poço em um período de 30 dias após a última escavação, para os diferentes pesos do fluido de perfuração.

Figura 3-40 - Deformações radiais na parede do poço em um período de um dia após a última escavação, para os diferentes pesos do fluido de perfuração.

Figura 3-41 - Deformação radial considerando: solução elástica, solução elástica e fluência em 1 dia e em 30 dias após a última escavação, para os diferentes pesos do fluido de perfuração.

Figura 3-42 - Deformações no sentido do eixo 1 em um período de 30 dias após a última escavação: (a) vista geral das deformações; (b) zoom na região ao redor do poço próxima a cota 6011 abaixo do nível do mar. Para obter os valores em porcentagem, deve-se multiplicar os resultados apresentados pelo Abaqus ${ }^{\circledR}$ por 100 .

Figura 3-43 - Tensões radiais ao redor do poço utilizando os diferentes pesos do fluido de perfuração em um período de fluência de 30 dias após a última escavação.

Figura 3-44 - Tensões radiais ao redor do poço utilizando os pesos de fluido de 9 ppg e 13 ppg, em um período de fluência de 30 dias após a última escavação.

Figura 3-45 - Tensões tangenciais ao redor do poço utilizando os diferentes pesos do fluido de perfuração.

Figura 3-46 - Tensões radiais ao redor do poço em $\mathrm{kPa}$ em um período de 30 dias após a última escavação: (a) vista geral das tensões radiais; (b) zoom na região ao redor do poço próxima a cota 6011 abaixo do nível do mar. 
Figura 4-1 - Representação da geometria com revestimento e cimento, com as condições de contorno, sem escala.

Figura 4-2 - Malha de elementos finitos utilizada na simulação numérica: (a) vista geral da malha; (b) detalhe da região próxima ao poço, com as malhas do revestimento e cimento.

Figura 4-3 - Etapa geostática, sem escala.

Figura 4-4 - Etapa elástica e fluência do sal, sem escala.

Figura 4-5 - Instalação do revestimento e pressão do fluido de perfuração $\left(P_{w}\right)$ na parede do poço, nas partes externa e interna do revestimento, sem escala.

Figura 4-6 - Revestimento com aplicação da pressão do fluido de cimento $\left(P_{w c}\right)$ na parede do poço, nas partes externa e interna do revestimento, sem escala.

Figura 4-7 - Revestimento com aplicação da pressão do fluido de cimento $\left(P_{w c}\right)$ na parede do poço e na parte externa do revestimento. Aplicação da pressão do fluido de perfuração $\left(P_{w}\right)$ na parte interna do revestimento, sem escala.

Figura 4-8 - Ativação da malha de cimento, com a continuidade da aplicação da pressão do fluido de perfuração $\left(P_{w}\right)$ na parte interna do revestimento, sem escala........ 155

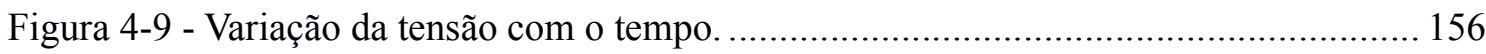

Figura 4-10 - Variação do módulo de elasticidade com o tempo. ....................................... 157

Figura 4-11 - Representação do nó de análise na parede do poço..................................... 158

Figura 4-12 - Deslocamento radial na parede do poço em um período de um mês de fluência após a escavação, para um fluido de perfuração com peso de 9 ppg - etapa 3.

Figura 4-13 - Deslocamento radial na parede do poço em um período de um dia de fluência após a escavação, para um fluido de perfuração com peso de 9 ppg - etapa 3.

Figura 4-14 - Deslocamento radial na parede do poço em um período de 11 dias com o cimento líquido, cimento de rigidez infinita e rigidez intermediária, para um fluido de perfuração com peso de 9 ppg.

Figura 4-15 - Deslocamento radial na parede do poço em um período de 11 dias de endurecimento do cimento com aumento da rigidez no tempo, com e sem a correta consideração das tensões (seguindo a Tabela 4-4). Análise da aplicação do cimento na fase líquida. Fluido de perfuração com peso de 9 ppg.

Figura 4-16 - Deslocamento radial na parede do poço em um período de 11 dias de endurecimento do cimento com aumento da rigidez no tempo, para um fluido de perfuração com peso de 11 ppg (seguindo a Tabela 4-4). 
Figura 4-17 - Deslocamento radial na parede do poço em um período de 11 dias de endurecimento do cimento com aumento da rigidez no tempo, para um fluido de perfuração com peso de 13 ppg (seguindo a Tabela 4-4).

Figura 4-18 - Deslocamento em metros no sentido do eixo 1 em um período de um mês de fluência após a escavação (etapa 3 ).

Figura 4-19 - Deslocamento em metros no sentido do eixo 1 após a instalação do revestimento e aplicação do cimento em estado líquido (etapa 6). .................... 165

Figura 4-20 - Deslocamento em metros no sentido do eixo 1 após o processo de endurecimento do cimento (etapa 27) ......................................................... 166

Figura 4-21 - Deformações radiais na parede do poço em um período de um mês de fluência após a escavação (etapa 3) e após o completo processo de endurecimento do cimento (etapa 27), para os diferentes pesos do fluido de perfuração.

Figura 4-22 - Deformações radiais na parede do poço: (a) em um período de um mês de fluência após a escavação - etapa 3 e; (b) após o completo processo de endurecimento do cimento - etapa 27. Para obter os valores em porcentagem, deve-se multiplicar os resultados apresentados pelo Abaqus ${ }^{\circledR}$ por 100 .

Figura 4-23 - Tensões ao redor do poço em um período de 30 dias de fluência após a escavação, para um peso de fluido de perfuração de $13 \mathrm{ppg}$.

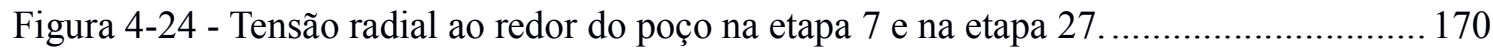

Figura 4-25 - Tensão tangencial ao redor do poço na etapa 7 e na etapa $27 \ldots \ldots \ldots \ldots \ldots \ldots \ldots \ldots . . . . .170$

Figura 4-26 - Tensão de von Mises no revestimento.

Figura 4-27 - Seção transversal de um tudo de revestimento submetido às pressões interna e externa.

Figura 4-28 - Detalhe da pressão do fluido de perfuração aplicada ao revestimento na etapa 4.

Figura 4-29 - Solução analítica versus Abaqus ${ }^{\circledR}$ : etapa $4-p_{i}=P_{w}=90,9 \mathrm{MPa} ; p_{e}=P_{w}=$ 90,9 MPa.

Figura 4-30 - Detalhe da pressão do fluido de cimento aplicada ao revestimento na etapa 5 .

Figura 4-31 - Solução analítica versus Abaqus ${ }^{\circledR}$ : etapa $5-p_{i}=P_{w c}=111,5 \mathrm{MPa} ; p_{e}=$ $P_{w c}=111,5 \mathrm{MPa}$.

Figura 4-32 - Detalhe das pressões dos fluidos de perfuração e cimento aplicadas ao revestimento na etapa 6 . 
Figura 4-33 - Solução analítica versus Abaqus ${ }^{\circledR}$ : etapa $6-p_{i}=P_{w}=90,9 \mathrm{MPa} ; p_{e}=P_{w c}$ $=111,5 \mathrm{MPa}$. 



\section{LISTA DE TABELAS}

Tabela 2-1 - Os minerais salinos............................................................................. 43

Tabela 2-2 - Densidade média de alguns minerais evaporíticos..................................... 44

Tabela 2-3 - Algumas das principais acumulações de petróleo descobertas no pré-sal da Bacia de Santos................................................................................... 47

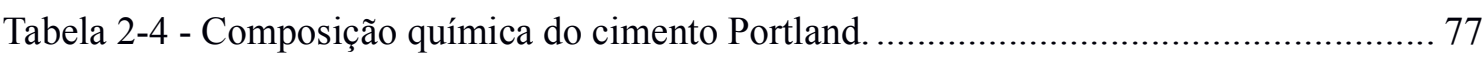

Tabela 3-1 - Cálculo das tensões de sobrecarga até $6000 \mathrm{~m}$ abaixo do nível do mar............. 92

Tabela 3-2- Pressões do fluido de perfuração na profundidade de estudo de $6000 \mathrm{~m}$

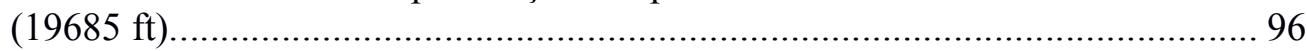

Tabela 3-3 - Modelos analisados para a definição do tamanho do domínio do problema. ..... 97

Tabela 3-4 - Refinamento do modelo axissimétrico..................................................... 125

Tabela 4-1 - Características dos estratos para o estudo de caso até a profundidade de $6000 \mathrm{~m}$ abaixo do nível do mar. ............................................................... 146

Tabela 4-2 - Parâmetros elásticos e constantes empíricas do sal.................................... 146

Tabela 4-3 - Parâmetros elasto-plásticos do revestimento. ............................................. 147

Tabela 4-4 - Propriedades elásticas do cimento dependentes do tempo. ........................... 147

Tabela 4-5 - Pressões do fluido de perfuração $\left(P_{w}\right)$ na profundidade de estudo de 6000

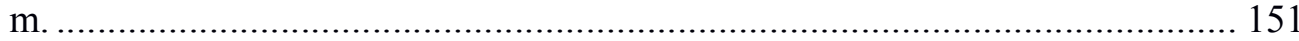





\section{LISTA DE ABREVIATURAS E SIGLAS}

2D

API

BOP

CAX4

CPE3

CPE4

FEM

ppg
Bidimensional

American Petroleum Institute

Blowout Preventer

Elemento contínuo, axissimétrico, quadrilateral bilinear, com 4 nós

Elemento contínuo, plano deformado, triangular linear, com 3 nós

Elemento contínuo, plano deformado, quadrilateral bilinear, com 4 nós

Finite Element Method

Pounds Per Gallon 



\section{LISTA DE SÍMBOLOS}

\begin{tabular}{|c|c|}
\hline$\varepsilon$ & Deformação \\
\hline$t$ & Tempo \\
\hline$\dot{\varepsilon}$ & Taxa de deformação ou fluência \\
\hline$d \varepsilon$ & Variação de deformação \\
\hline$d t$ & Intervalo de tempo \\
\hline$\varepsilon_{0}$ & Deformação elástica instantânea \\
\hline$\dot{\varepsilon}_{0}$ & Taxa de deformação de referência \\
\hline$\sigma$ & Tensão desviadora \\
\hline$\sigma_{1}$ & Tensão desviadora de referência \\
\hline$G$ & Módulo de cisalhamento \\
\hline$R$ & Constante universal dos gases \\
\hline$T$ & Temperatura absoluta \\
\hline$T_{0}$ & Temperatura de referência \\
\hline$A$ & Constante \\
\hline$n$ & Expoente de tensão \\
\hline$H$ & Função Heaviside \\
\hline$Q$ & Energia de ativação \\
\hline$B$ & Constante \\
\hline$q$ & Constante \\
\hline$K, a, b, c$ e $j$ & Constantes empíricas \\
\hline$E$ & Módulo de elasticidade \\
\hline$\eta$ & Coeficiente de viscosidade \\
\hline$\sigma^{e}$ & Tensão no elemento de mola \\
\hline$\sigma^{v}$ & Tensão no amortecedor \\
\hline$\varepsilon^{e}$ & Deformação no elemento de mola \\
\hline$\varepsilon^{v}$ & Deformação no amortecedor \\
\hline$\dot{\sigma}$ & Taxa de tensão \\
\hline$E_{1}$ & Módulo de elasticidade do elemen \\
\hline
\end{tabular}




\begin{tabular}{|c|c|}
\hline$E_{2}$ & Módulo de elasticidade do elemento 2 \\
\hline$\eta_{1}$ & Coeficiente de viscosidade do elemento 1 \\
\hline$\eta_{2}$ & Coeficiente de viscosidade do elemento 2 \\
\hline$\ddot{\varepsilon}$ & Derivada segunda da deformação \\
\hline$m$ & Constante definida em função da temperatura \\
\hline$\sigma_{v}$ & Tensão de sobrecarga \\
\hline$\rho$ & Massa específica \\
\hline$g$ & Aceleração da gravidade \\
\hline$D$ & Profundidade de estudo \\
\hline$z$ & Profundidade \\
\hline$d z$ & Variação da profundidade \\
\hline$\sigma_{h}$ & Tensão horizontal \\
\hline$K_{0}$ & Coeficiente de empuxo em repouso \\
\hline$v$ & Coeficiente de Poisson \\
\hline$\sigma_{r}$ & Tensão normal efetiva na direção radial \\
\hline$\sigma_{\theta}$ & Tensão normal efetiva na direção tangencial \\
\hline$\sigma_{1}$ & Tensão in situ na direção 1 \\
\hline$\sigma_{2}$ & Tensão in situ na direção 2 \\
\hline$R$ & Raio do poço \\
\hline$r$ & Distância a partir do eixo do poço \\
\hline$\theta$ & Ângulo medido no sentido anti-horário do plano 1-2 a partir do eixo 1 \\
\hline$P_{w}$ & Pressão do fluido de perfuração \\
\hline$\gamma$ & Peso específico \\
\hline$Z$ & Distância à frente da escavação \\
\hline$P_{w c}$ & Pressão do fluido de cimento \\
\hline$u_{r}$ & Deslocamento radial \\
\hline$d \sigma$ & Variação de tensão \\
\hline$D(t)$ & Matriz de elasticidade \\
\hline$\varepsilon_{t_{1}, t_{2}}$ & Deformação acumulada no intervalo de tempo entre $t_{1}$ e $t_{2}$ \\
\hline$p_{i}$ & Pressão do fluido na região interna do revestimento \\
\hline$p_{e}$ & Pressão do fluido na região externa do revestimento \\
\hline
\end{tabular}


Raio interno do revestimento

$r_{0}$

Raio externo do revestimento 



\section{SUMÁRIO}

1 INTRODUÇÃ

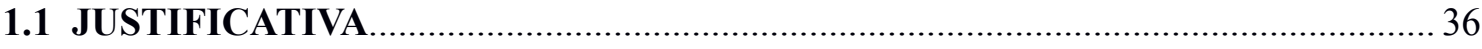

1.2 OBJETIVOS

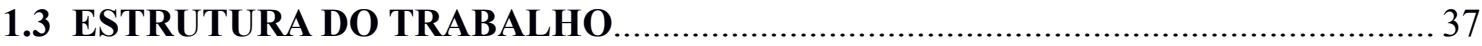

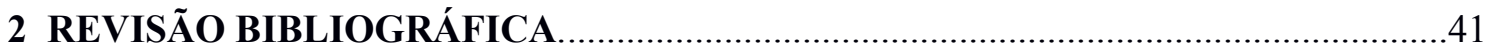

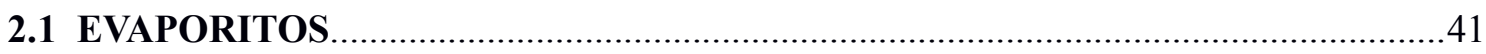

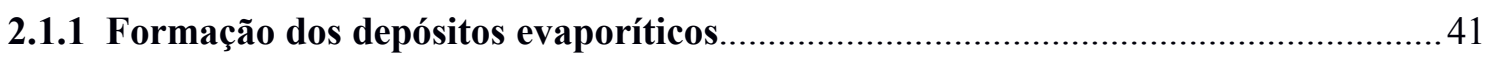

2.1.2 Relação dos evaporitos com o petróleo................................................................. 45

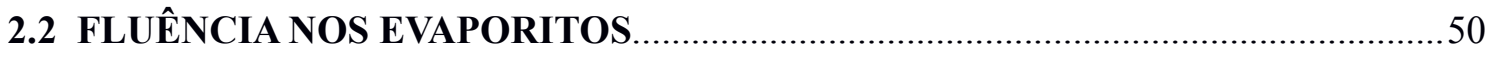

2.2.1 Estágios de comportamento de fluência.................................................................51

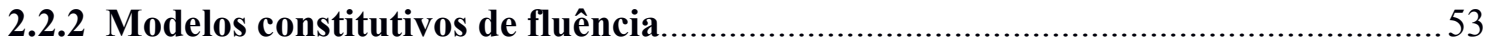

2.2.2.1 Leis associadas a processos físicos.......................................................................... 53

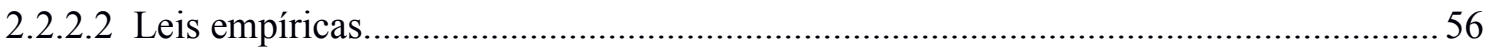

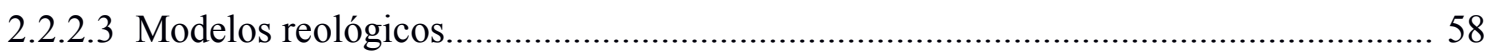

2.3 PERFURAÇÃO DE POÇOS DE PETRÓLEO EM ZONAS SALINAS.......................65

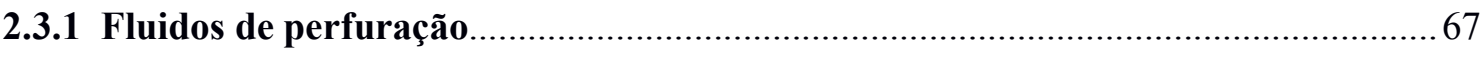

2.3.2 Etapas de revestimento e cimentação.......................................................................69

2.3.2.1 Revestimento....................................................................................................70

2.3.2.2 Cimentação ......................................................................................................73

2.3.3 Problemas na perfuração em evaporitos................................................................ 78

3 MODELAGEM NUMÉRICA DA PERFURAÇÃO DE UM POÇO EM

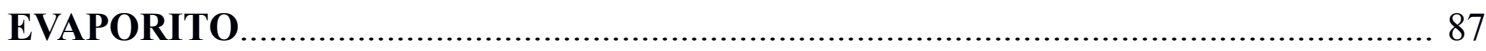

3.1 EQUAÇÕES CONSTITUTIVAS DE FLUÊNCIA NO ABAQUS®......................... 88

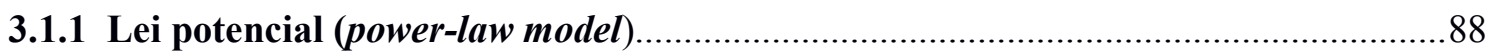

3.1.2 Lei seno-hiperbólica (hyperbolic-sine law model) ………………………………....... 89

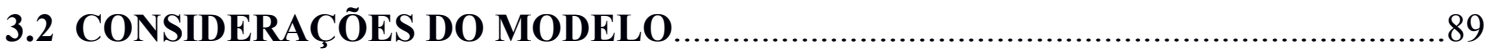

3.3 MODELO PLANO DE DEFORMAÇÃO DO POÇO...............................................93

3.3.1 Dimensões do modelo e validação do programa abaqus ${ }^{\circledR}$......................................... 96

3.3.1.1 Solução de Kirsch.................................................................................................... 97

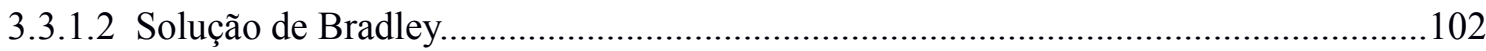

3.3.2 Resultados e discussões da simulação do poço de petróleo em evaporito ……….... 105 


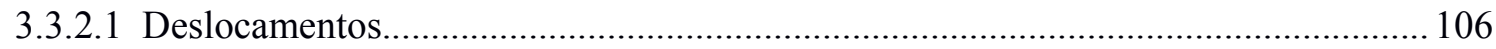

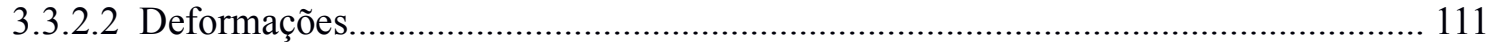

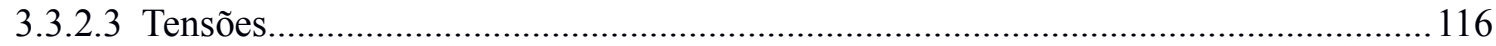

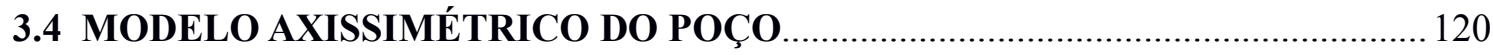

3.4.1 Análise das dimensões e refinamento do modelo............................................. 123

3.4.2 Resultados e discussões da simulação do poço de petróleo em evaporito.............. 128

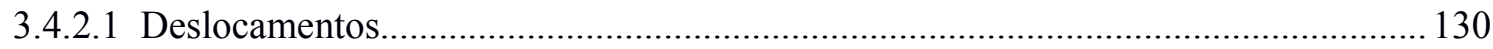

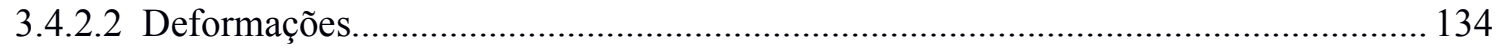

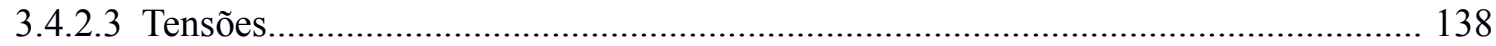

4 REVESTIMENTO E CIMENTAÇÃO DE UM POÇO DE PETRÓLEO EM

EVAPORITO

4.1 CONSIDERAÇÕES DO MODELO COM REVESTIMENTO E

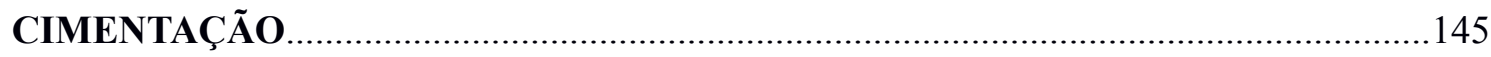

4.2 ETAPAS DA SIMULAÇÃO DA PERFURAÇÃO, REVESTIMENTO E

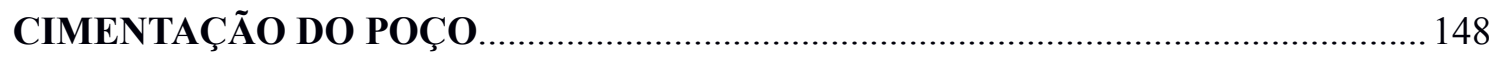

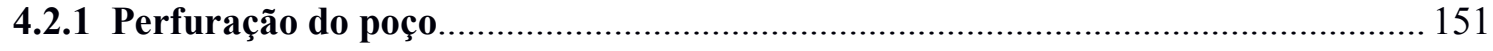

4.2.2 Revestimento e aplicação do cimento no estado líquido.......................................153

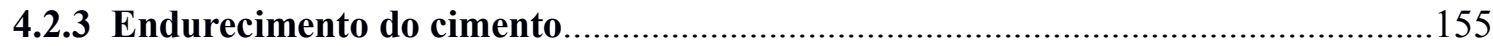

4.3 RESULTADOS E DISCUSSÕES DA PERFURAÇÃO, REVESTIMENTO E CIMENTAÇÃO DO POÇO DE PETRÓLEO EM EVAPORITO.................................. 157

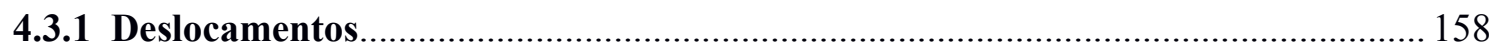

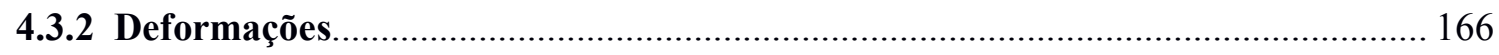

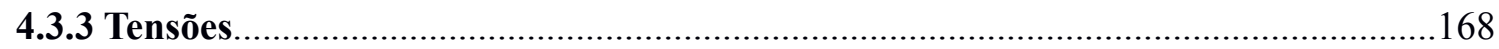

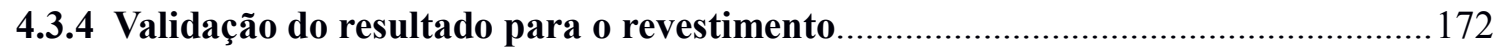

5 CONCLUSÕES E SUGESTÕES DE TRABALHOS FUTUROS..............................179

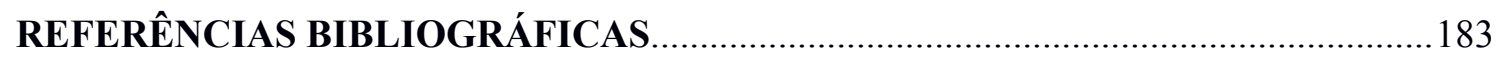




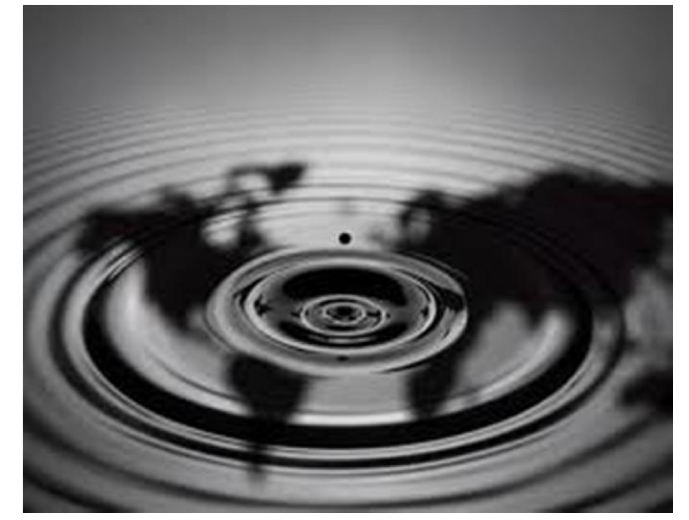

Capítulo 1

INTRODUÇÃO 


\section{INTRODUÇÃ̃O}

Os hidrocarbonetos são encontrados sob alta pressão em rochas porosas, denominadas rochas reservatório. Para localizar o petróleo ou gás em uma bacia sedimentar, os especialistas firmam-se no conhecimento de que o petróleo aloja-se em uma estrutura localizada na parte mais alta de um compartimento de rocha porosa, estando isolada por camadas impermeáveis, denominadas de rochas selantes ou capeadoras (MILANI et al., 2000).

$\mathrm{Na}$ camada pré-sal, encontram-se rochas reservatório cobertas por uma camada impermeável de sal com grande espessura. A principal razão para o estudo dos evaporitos se deve ao fato de que as estruturas salinas estão relacionadas ao aprisionamento de hidrocarbonetos devido a algumas propriedades, como porosidade e permeabilidade praticamente nulas, o que faz do sal excelente rocha capeadora. Muitas reservas de petróleo do mundo estão associadas a estruturas salinas (FARMER et al., 1996).

Entretanto, apesar de o sal apresentar propriedades peculiares que facilitam o aprisionamento dos hidrocarbonetos, o sal também apresenta características indesejáveis à perfuração. Alguns evaporitos apresentam grande plasticidade, deformando-se intensamente após a broca ultrapassá-los. Esta deformação imediata soma-se à deformação ao longo do tempo, fenômeno denominado por fluência ou creep. A fluência, em alguns casos, pode ser mais expressiva que a deformação imediata, e pode acarretar no fechamento rápido do poço em volta da coluna de perfuração, podendo prendê-la. Ainda, a fluência pode levar ao colapso os revestimentos de um poço de petróleo revestido.

A formação dos depósitos evaporíticos brasileiros está relacionada com a separação continental, a qual deu origem a golfos, anteriores à separação total, ao longo de toda costa atual. Isso resultou na restrição do fluxo de água do mar, que associado a condições ambientais como evaporação, clima seco e quente, foram favoráveis à formação destes depósitos no litoral brasileiro (CHRISTANTE, 2009). As descobertas de petróleo abaixo destes depósitos, localizados em profundidades de até 7000 metros, sendo que a espessura destas camadas salinas pode chegar a 3000 metros, geram desafios para a indústria de petróleo e gás.

Após a perfuração dos poços de petróleo, o revestimento é instalado com a finalidade de impedir o colapso das paredes do poço e fornecer um isolamento hidráulico, impedindo a passagem de fluidos para as formações. Geralmente, o espaço anular entre a coluna de revestimento e as paredes do poço é preenchido com cimento, garantindo a sua segurança. $\mathrm{O}$ 
processo de cimentação é uma das etapas mais importantes da perfuração, tendo grande impacto sobre a produtividade do poço, pois quando mal realizada pode causar até a perda do mesmo.

Estudos relacionados às propriedades das rochas salinas e a sua perfuração vêm sendo realizados, bem como os estudos do revestimento de poços e propriedades da pasta de cimento. Giambastiani (2005) utilizou diversas técnicas diretas e indiretas para analisar os possíveis mecanismos físicos de fluência em rochas sulfáticas, em condições de carregamento uniaxial e temperatura ambiente. Weatherby, Munson e Argüello (1996) utilizaram resultados de simulações numéricas e ensaios físicos para o estudo dos problemas decorrentes da fluência do sal para a construção de depósitos subterrâneo de lixo nuclear.

\subsection{JUSTIFICATIVA}

Como dito anteriormente, os sais apresentam algumas características indesejáveis à perfuração. Suas propriedades mecânicas são influenciadas pelas condições de temperatura e pressão a que estão submetidos. As formações salinas são encontradas em grandes profundidades, e consequentemente, sob altas condições de tensão de confinamento e temperatura. Desta forma, as deformações plásticas e taxas de deformação são agravadas ao longo do tempo.

A descoberta de reservas de petróleo em campos cada vez mais profundos, seguido dos problemas decorrentes dos complexos cenários em que são encontrados, torna a sua extração um desafio. Segundo Farmer et al. (1996), considerações especiais, desde a seleção de fluidos de perfuração até a implementação de programas de revestimento e cimentação, são necessários para produzir poços de longa duração.

Nesse sentido, é interessante a busca por soluções que melhorem a estratégia de perfuração do poço, proporcionando a escolha adequada do fluido de perfuração a ser utilizado, a correta instalação do revestimento e cimentação do poço que evite a propagação da fluência do sal, possibilitando a execução de projetos mais seguros e econômicos.

\subsection{OBJETIVOS}

O objetivo deste trabalho é estudar as rochas salinas, suas principais características e sua relação com o petróleo. Ainda, pretende-se realizar um estudo numérico do 
comportamento geomecânico do sal em poços de petróleo, utilizando o software comercial de elementos finitos Abaqus ${ }^{\circledR}$. Analisa-se o efeito da fluência do sal durante e após a perfuração e cimentação dos poços, para diferentes pesos de fluido de perfuração, avaliando o comportamento dos deslocamentos, deformações e tensões nas fronteiras sal-cimento.

A geração de modelos mais fiéis, que representem a deformação da rocha salina no processo de perfuração dos poços, possibilita que os furos sejam mais bem produzidos, evitando custos muito elevados e até mesmo a perda dos poços.

\subsection{ESTRUTURA DO TRABALHO}

Este trabalho está organizado em cinco capítulos, incluindo esta introdução que caracteriza o Capítulo 1 e as referências bibliográficas. Nesta seção é realizada uma síntese de cada capítulo.

No Capítulo 2 é apresentada uma revisão bibliográfica abordando alguns conceitos relacionados aos evaporitos, sua formação, características e relação com a exploração do petróleo. Em seguida, é abordado o conceito de fluência nos evaporitos, seus estágios e seus modelos constitutivos (empíricos, físicos e reológicos). Ainda, destacam-se as etapas para a construção de poços de petróleo em zonas salinas, como a perfuração e os tipos de fluido de perfuração, revestimento e cimentação do poço. Também, são citados os problemas que podem ocorrer devido à perfuração em evaporitos.

No Capítulo 3 são realizadas modelagens numéricas no Abaqus ${ }^{\circledR}$ com a utilização da análise plana de deformação e análise axissimétrica para avaliar o comportamento do sal ao ser perfurado. Inicialmente são explicadas as equações constitutivas de fluência utilizadas pelo Abaqus ${ }^{\circledR}$. Em seguida, são apresentadas as considerações de cada modelo, plano e axissimétrico, com suas condições de contorno e parâmetros utilizados nas formulações baseados em Botelho (2008). Ainda, é realizado um estudo para a definição das dimensões da geometria e refinamento da malha, o qual é validado com o emprego das equações elásticas de Kirsch (1898) e Bradley (1979) para a análise de deformação plana e Panet (1979) para a análise axissimétrica. Por fim, são apresentados os resultados dos deslocamentos, deformações e tensões decorrentes da perfuração do poço de petróleo em evaporito, utilizando diferentes pesos do fluido de perfuração.

O Capítulo 4 apresenta a simulação das etapas de revestimento e cimentação do poço de petróleo em evaporito, levando em consideração o modelo plano de deformação 
apresentado no Capítulo 3, sendo esta a principal contribuição aos estudos de Botelho (2008). Realiza-se a modelagem do processo de endurecimento do cimento ao longo do tempo. São apresentadas as análises de deslocamento e deformação na parede do poço e a tensão no revestimento, cimento e sal durante o aumento progressivo de rigidez do cimento. Além disso, é realizada a verificação do comportamento do revestimento quando aplicadas as pressões do fluido de cimento e do fluido de perfuração, comparando a solução numérica com a solução analítica.

Finalmente, o Capítulo 5 apresenta as conclusões deste estudo e algumas sugestões para trabalhos futuros relacionados com o tema. Após este capítulo são listadas as referências bibliográficas citadas no trabalho. 


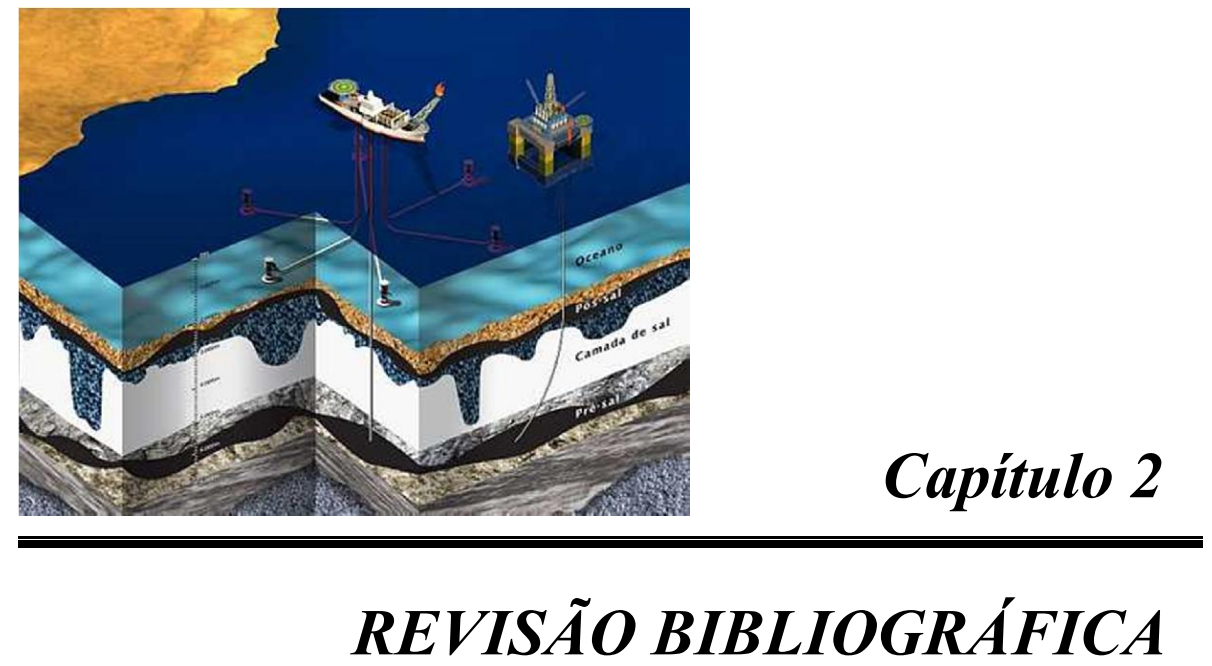




\section{REVISÃO BIBLIOGRÁFICA}

\subsection{EVAPORITOS}

Os evaporitos ou rochas salinas são rochas sedimentares que geralmente se formam em ambientes de sedimentação de baixo aporte de materiais terrígenos, submetidos a elevada taxa de evaporação, que permite a cristalização e precipitação dos sais contidos em meios aquosos. Assim, os evaporitos podem ser formados nos locais em que a taxa de evaporação da massa de água é maior do que o influxo total de água, deixando um resíduo mineral concentrado (SCHREIBER; EL TABAKH, 2000)..

Inicialmente os estudos sobre rochas evaporíticas possuíam uma abordagem basicamente química. O italiano Usiglio foi um dos primeiros a observar a evaporação da água do mar em laboratório em 1849, demonstrando pela primeira vez que uma série de minerais se precipitavam em uma determinada ordem durante a evaporação de um volume de água salgada (FREITAS, 2006). Segundo Silva, Schreiber e Santos (2000), os estudos sobre esta rocha, tornaram-se nos anos 60 do século XX um estudo mais geológico e sedimentológico, com análise das rochas sedimentares e a sua formação. A principal razão dessa mudança foi a descoberta de faciologias evaporíticas costeiras na Costa Trucial do Golfo da Pérsia (CURTIS et al., 1963). Com estes estudos, foi possível obter modelos de fácies e sequências deposicionais que passaram a ser utilizados na geologia do petróleo.

O conhecimento atual sobre os evaporitos deixa clara a sua importância sob o ponto de vista econômico, visto que o cloreto de sódio ou sal de cozinha, como é popularmente conhecido, é um dos minerais evaporíticos de maior importância para o ser humano. Ainda, os evaporitos costumam estar associados a grandes acumulações petrolíferas, exercendo importante função como rocha selante do reservatório de petróleo.

\subsubsection{Formação dos depósitos evaporíticos}

Os depósitos evaporíticos são formados por diversos minerais resultantes de evaporação intensa. Tais depósitos podem ser de origem continental ou marinha em que haja aporte periódico de água salgada. Em muitas regiões do mundo é possível encontrar depósitos evaporíticos em ambientes onde a razão de evaporação excede a razão de precipitação ou 
outra chegada de água. Ainda, outro fator importante é a discreta contribuição sedimentar de terrígenos de fora da bacia (SILVA; SCHREIBER; SANTOS, 2000). A Figura 2-1 apresenta uma camada evaporítica em um depósito no Chipre, ilha no leste do mar Mediterrâneo ao sul da Turquia (BOTELHO, 2008).

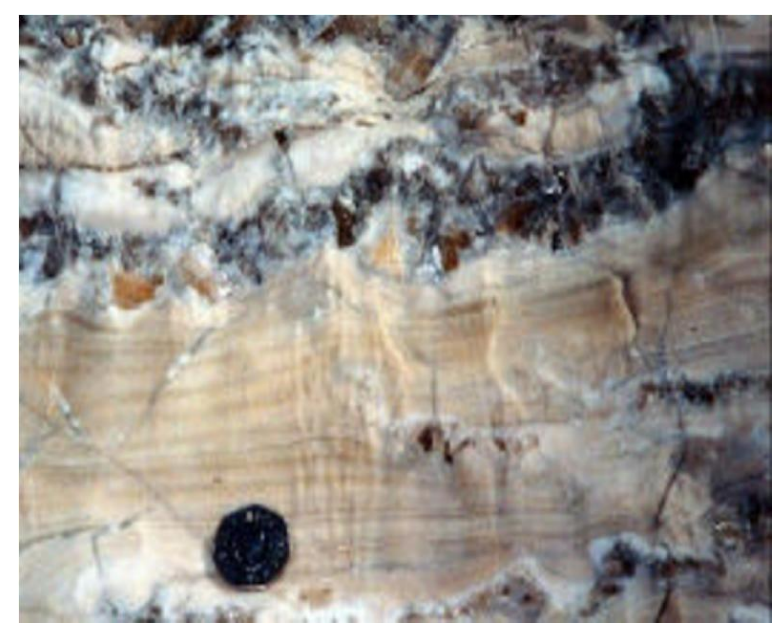

Figura 2-1 - Camada evaporítica, sem escala informada. Fonte: Botelho (2008).

Os três fatores críticos que controlam a formação dos minerais evaporíticos e seu acúmulo são: a baixa umidade relativa do ar, a temperatura e o conteúdo iônico inicial (e suas relações). Isto independe se o ambiente de formação é de caráter continental ou marinho (SCHREIBER; EL TABAKH, 2000). A formação de evaporitos marinhos requer estado de extrema restrição de circulação de águas marinhas oferecidas por condições geomorfológicas, estruturais ou mesmo orgânicas (recifes), aliada aos fatores que possibilitem a evaporação (MELO; CARVALHO; PINTO, 2008). Em ambientes não marinhos, a formação se dá no interior dos continentes, como por exemplo, lagunas e lagos salgados isolados, importantes para a formação de camadas espessas de sais em sequências lacustres (MOHRIAK; SZATMAN; ANJOS, 2008).

A intensa evaporação da água em bacias restritas resulta no aumento da concentração dos íons, formando uma solução salina concentrada (salmoura). Cada vez que a concentração destes íons ultrapassa sua solubilidade na água, estes são precipitados, gerando depósitos evaporíticos formados por diversos minerais. Segundo Silva, Schreiber e Santos (2000), os tipos de sais complexos e as respectivas salinidades da salmoura variam de acordo com a temperatura ou com os níveis de matéria orgânica presentes na salmoura.

Apesar de os depósitos evaporíticos se originarem da água do mar, eles exibem grande 
variedade em suas composições, decorrentes das diferentes solubilidades dos componentes originais da água do mar e das condições ambientais durante o processo de precipitação destes componentes. De acordo com Silva, Schreiber e Santos (2000), a química da água do mar é dominada pelos íons $\mathrm{Na}^{+}$e $\mathrm{Cl}^{-}$, e quantidades menores de $\mathrm{SO}_{4}{ }^{2-}, \mathrm{Mg}^{2+}, \mathrm{Ca}^{2+}, \mathrm{K}^{1+}, \mathrm{CO}_{3}{ }^{2-}$ e $\mathrm{HCO}_{3}{ }^{1-}$.

Ao iniciar a evaporação, os componentes mais solúveis permanecem dissolvidos, enquanto que os menos solúveis precipitam. Desta forma, a deposição de camadas salinas segue uma ordem definida, ocorrendo do menos solúvel para o mais solúvel. De acordo com Mohriak; Szatman e Anjos (2008), o primeiro mineral a precipitar é o carbonato (como exemplo temos a calcita), seguido do sulfato (anidrita ou gipso). Após a precipitação destes minerais, precipitam-se em ordem a halita, silvita, carnalita, bischofita e taquidrita. Estes últimos são chamados de cloretos ou sais solúveis. Estes minerais estão representados na Tabela 2-1.

Tabela 2-1 - Os minerais salinos.

\begin{tabular}{ccc}
\hline MINERAL & FÓRMULA & SOLUBILIDADE \\
\hline Calcita & $\mathrm{CaCO}_{3}$ & Pouco solúvel \\
Anidrita & $\mathrm{CaSO}_{4}$ & Pouco solúvel \\
Gipsita & $\mathrm{CaSO}_{4} \cdot 2 \mathrm{H}_{2} \mathrm{O}$ & Pouco solúvel \\
Halita & $\mathrm{NaCl}$ & Solúvel \\
Silvita & $\mathrm{KCl}$ & Solúvel \\
Carnalita & $\mathrm{KMgCl}_{3} \cdot 6 \mathrm{H}_{2} \mathrm{O}$ & Solúvel \\
Bischofita & $\mathrm{MgCl}_{2} \cdot 6 \mathrm{H}_{2} \mathrm{O}$ & Solúvel \\
Taquidrita & $\mathrm{CaCl}_{2} \cdot 2 \mathrm{MgCl}_{2} \cdot 12 \mathrm{H}_{2} \mathrm{O}$ & Solúvel \\
\hline
\end{tabular}

Fonte: Modificada de Warren (2006).

Os evaporitos apresentam baixa resistência mecânica e sofrem deformação contínua. Ainda, são praticamente incompressíveis e a sua densidade praticamente constante, independente da profundidade. No entanto, os sedimentos que sobrepõem os evaporitos, quando em maiores profundidades, adquirem uma maior densidade, tornando-se mais denso que o sal e provocando uma situação de instabilidade (FARMER et al., 1996). Devido a esta diferença de densidades e às características do sal é que ele encontra facilidade para se movimentar lateralmente e verticalmente, formando estruturas salíferas ou halocinéticas, como os domos salinos. A Tabela 2-2 informa os valores de densidade dos diferentes minerais 
evaporíticos.

Tabela 2-2 - Densidade média de alguns minerais evaporíticos.

\begin{tabular}{cc}
\hline MINERAL & DENSIDADE DO GRÃO $\left(\mathrm{g} / \mathrm{cm}^{3}\right)$ \\
\hline Anidrita & 2,94 \\
Calcita & 2,72 \\
Gipsita & 2,32 \\
Halita & 2,16 \\
Silvita & 1,98 \\
Taquidrita & 1,67 \\
Bischofita & 1,60 \\
Carnalita & 1,60 \\
\hline
\end{tabular}

Fonte: Modificada de Haas Júnior et al. (1981).

De acordo com Farmer et al. (1996), quando as camadas sobrejacentes oferecem pouca resistência à movimentação do sal, como é o caso do Golfo do México, o sal pode ascender e muitas vezes arrastar camadas encaixantes, criando domos característicos, almofadas e cunhas que encaixam nas camadas sedimentares acima (Figura 2-2a). Caso as rochas sobrejacentes não resistam ao encaixamento, o sal abaixo pode se deslocar empurrando as camadas, levantando-as e criando falhas radiais durante o processo (Figura 2-2b). Se as condições tectônicas forem adequadas, o falhamento extensional na camada rígida pode abrir caminho para a ascensão do sal (Figura 2-2c). As estruturas salinas, como o domo, servem de armadilha ou trapa para o armazenamento do petróleo.

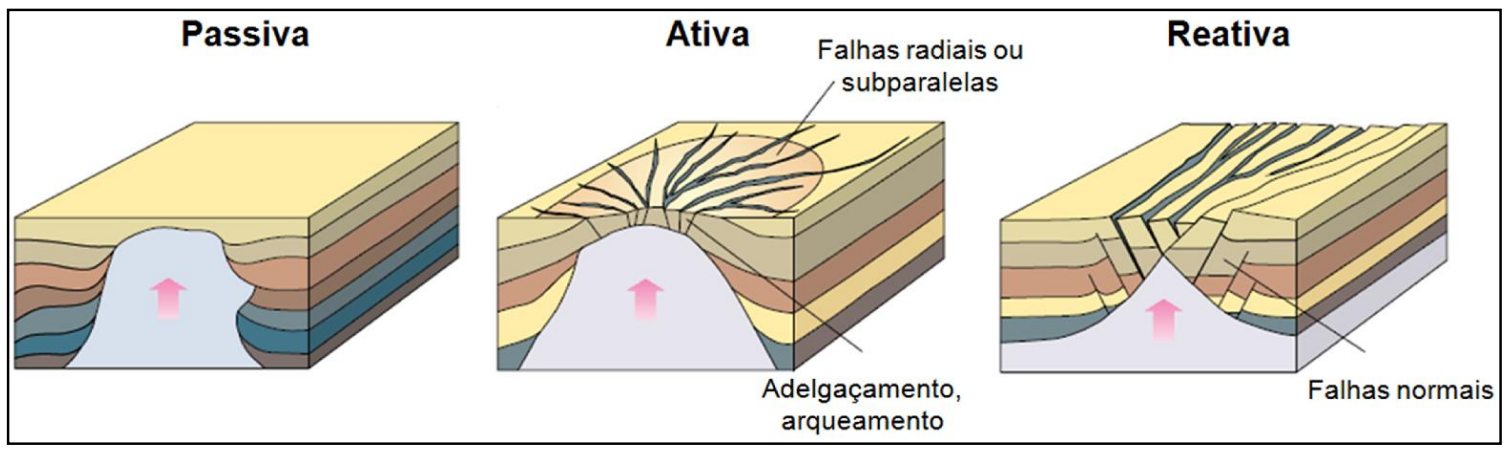

(a)

(b)

(c)

Figura 2-2 - Estilos de intrusão do sal: (a) Passiva - nenhum problema de espaço; (b) Ativa - espaço criado por diápiro; (c) Reativa - espaço criado por extensão.

Fonte: Modificada de Farmer et al. (1996). 


\subsubsection{Relação dos evaporitos com o petróleo}

O petróleo é composto por uma mistura complexa de hidrocarbonetos e quantidades variáveis de não-hidrocarbonetos (THOMAS et al., 2004). Para a ocorrência de petróleo em quantidade significativa em uma bacia sedimentar, é necessária a existência de um grande volume de matéria orgânica de qualidade adequada acumulada. Esta matéria orgânica se concentra em certas rochas sedimentares, denominadas de geradoras, as quais ao serem submetidas a adequadas condições de temperatura e pressão podem gerar petróleo (MILANI et al., 2000).

Uma acumulação de petróleo em uma bacia sedimentar requer a associação de uma série de fatores. Entre eles, cita-se a presença de uma rocha geradora e condições temporais adequadas, além da existência da rocha reservatório com porosidade e permeabilidade necessária à acumulação e produção do petróleo. Ainda, é necessária a presença de condições favoráveis à migração do petróleo da rocha geradora até a rocha reservatório, bem como a existência de uma rocha impermeável que retenha o fluxo do petróleo. A esta rocha impermeável, denomina-se rocha selante ou capeadora (THOMAS et al., 2004). Segundo Milani et al. (2000), todos esses fatores devem ser originados e desenvolvidos em uma escala de tempo adequado para a formação de acumulações de petróleo. Sendo assim, a ausência de apenas um desses fatores inviabiliza a formação de uma jazida petrolífera (Figura 2-3).

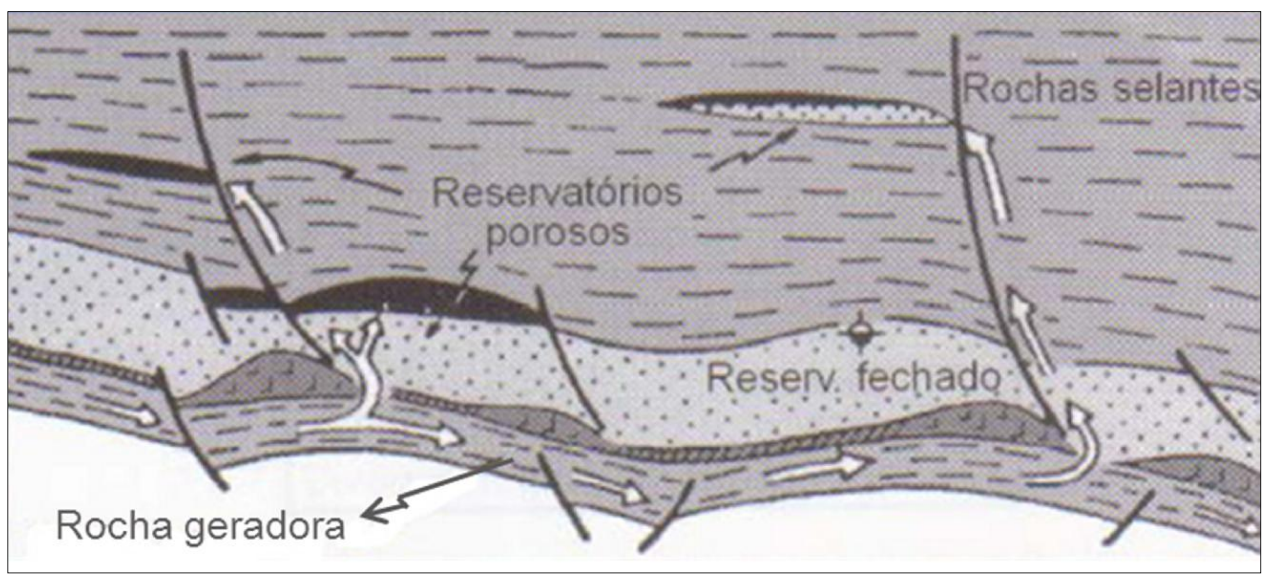

Figura 2-3 - Relações entre rochas geradoras, reservatório e selantes. Fonte: Thomas et al. (2004).

Os evaporitos solúveis são praticamente impermeáveis, sendo uma característica importante para a indústria do petróleo na medida em que o sal ajuda a criar estruturas 
selantes de hidrocarbonetos, propiciando o seu acúmulo. Além do acúmulo de hidrocarbonetos, a característica selante destas rochas torna seu uso interessante para o estoque de gás e lixos atômicos em cavernas salinas. Essas aplicações, junto à descoberta de reservas de petróleo, tornaram o estudo do comportamento dessas rochas importante devido aos altos investimentos das indústrias envolvidas.

É possível encontrar os evaporitos em várias bacias de hidrocarbonetos ao redor do mundo (Figura 2-4). Existem depósitos significativos nas águas profundas do Golfo do México e em regiões offshore do oeste da África, no Brasil, no Sul do Mar do Norte e Oriente Médio (BOTELHO, 2008).

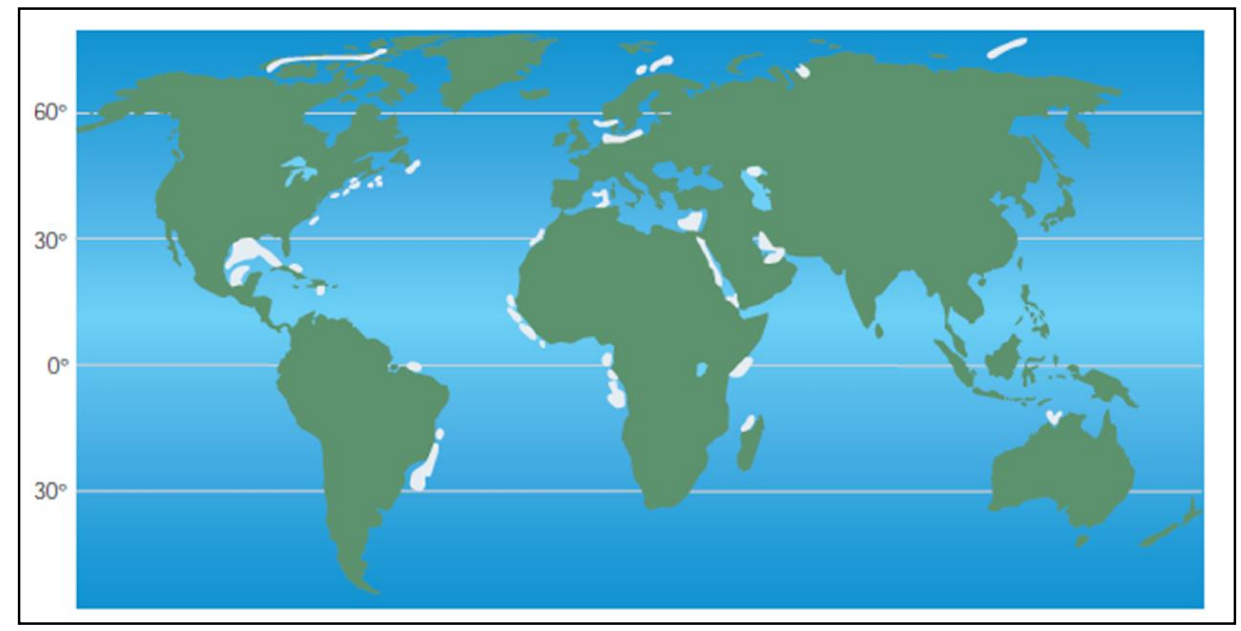

Figura 2-4 - Depósitos globais de sais indicados pelas áreas brancas. Fonte: Farmer et al. (1996).

$\mathrm{Na}$ camada pré-sal, encontram-se rochas reservatórios cobertas por uma camada impermeável de sal com grande espessura. Deste modo, as rochas geradoras foram depositadas antes da camada de sal. Segundo a Petrobras, a profundidade total dessas rochas, dada pela distância entre a superfície do mar e os reservatórios de petróleo abaixo da camada de sal, pode chegar a mais de 7 mil metros (Figura 2-5). Ainda, a espessura das camadas salinas, em certas áreas da costa, atinge até 2000 metros, com uma lâmina d'água de 2000 a 2500 metros. 


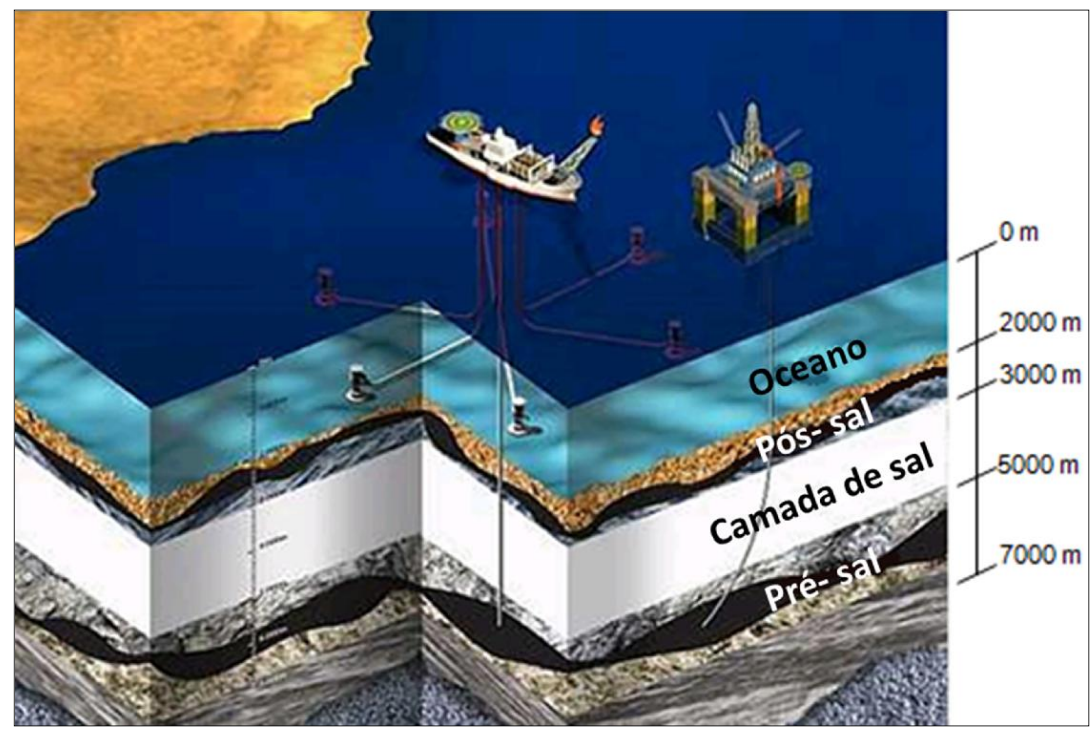

Figura 2-5 - Camada Pré-sal.

Fonte: Modificada de Petrobras (2009).

Recentemente, as maiores descobertas de petróleo, no Brasil, foram realizadas pela Petrobras. Os reservatórios do pré-sal apresentam volumes de petróleo bastante significativos, de alta qualidade e alto valor de mercado. A principal zona de ocorrência de evaporitos no Brasil situa-se na Costa Leste, desde Santos até Sergipe-Alagoas, e as maiores extensões de evaporitos se encontram na Bacia de Santos (BENGALY, 2003). A Tabela 2-3 mostra os valores das profundidades do reservatório e a lâmina d'água de algumas das principais acumulações de petróleo descobertas no pré-sal da Bacia de Santos entre os anos de 2006 a 2012.

Tabela 2-3 - Algumas das principais acumulações de petróleo descobertas no pré-sal da Bacia de Santos.

\begin{tabular}{cccc}
\hline Área / Poço & Data & $\begin{array}{c}\text { Profundidade do poço ou do } \\
\text { reservatório (metros) }\end{array}$ & $\begin{array}{c}\text { Lâmina d'água } \\
\text { (metros) }\end{array}$ \\
\hline Tupi (atual Lula) & $09 / 2006$ & 5200 & 2126 \\
Caramba & $12 / 2007$ & 5350 & 2234 \\
Bem-te-vi & $05 / 2008$ & 6773 & 2139 \\
Iracema & $06 / 2009$ & 5000 & 2210 \\
Biguá & $11 / 2011$ & 5380 & 2180 \\
Carioca Norte & $10 / 2012$ & 5576 & 2152 \\
\hline
\end{tabular}

Fonte: Modificada de Morais (2013). 
Um conjunto de fatores climáticos e geológicos acomodou de forma aleatória o petróleo e o gás que estão abaixo da camada de sal sob águas profundas e distantes da costa. A formação do petróleo do pré-sal no Brasil ocorreu no período do Cretáceo, há mais ou menos 130 milhões de anos quando a América do Sul e a África formavam um só bloco, o supercontinente Gondwana. Com o movimento das placas tectônicas uma fissura foi aberta entre o que hoje são as costas brasileira e africana. Essa fenda foi drenando os cursos d'água das redondezas que somadas com as águas da chuva, formaram-se enormes lagos, nos quais os fitoplânctons encontraram condições adequadas para viverem e se reproduzirem ao longo de alguns milhões de anos, período suficiente para acumular grande quantidade de matéria orgânica morta no fundo do lago (CHRISTANTE, 2009).

As placas tectônicas continuaram a se afastar e a fenda continuou a crescer, aumentando a largura e profundidade dos lagos, até o ponto em que águas oceânicas começaram a invadir a região. Carbonato de cálcio e magnésio foram excretados por cianobactérias que habitaram o local, formando rochas carbonáticas microbianas. As águas salgadas continuaram a invadir a região. Todo este processo, associado a condições ambientais como volume original, clima seco e quente, evaporação, foram favoráveis para formação de depósitos evaporíticos no litoral brasileiro. Com a formação completa do Atlântico Sul, tudo foi parar a vários quilômetros de profundidade, em uma configuração adequada para a formação de campos de petróleo (CHRISTANTE, 2009). Assim, a rocha geradora foi formada da combinação da matéria orgânica depositada no fundo do antigo lago com a argila, que com o passar do tempo e em condições favoráveis, formaram os hidrocarbonetos. As rochas carbonáticas microbianas, altamente porosas, são locais propícios ao armazenamento destes hidrocarbonetos. Por fim, a espessa camada de sal manteve o óleo e o gás armazenados na rocha reservatório. A Figura 2-6, representa o processo para a formação dos evaporitos na costa brasileira.

A camada de sal também existe em outras regiões, mesmo em terra, como por exemplo no município de Carmópolis, em Sergipe. Mesmo o petróleo da bacia de Campos, extraído desde os anos de 1970, tem origem em camadas abaixo do sal. São hidrocarbonetos que escaparam para as rochas superiores, calcários e arenitos, por meio de rasgos existentes na camada de sal, em áreas sob mar mais raso, onde a camada é mais fina. Desta forma, a maior parte do petróleo extraído no Brasil tem origem nos lagos antigos que precederam o Atlântico Sul (OLIVEIRA, 2008). 


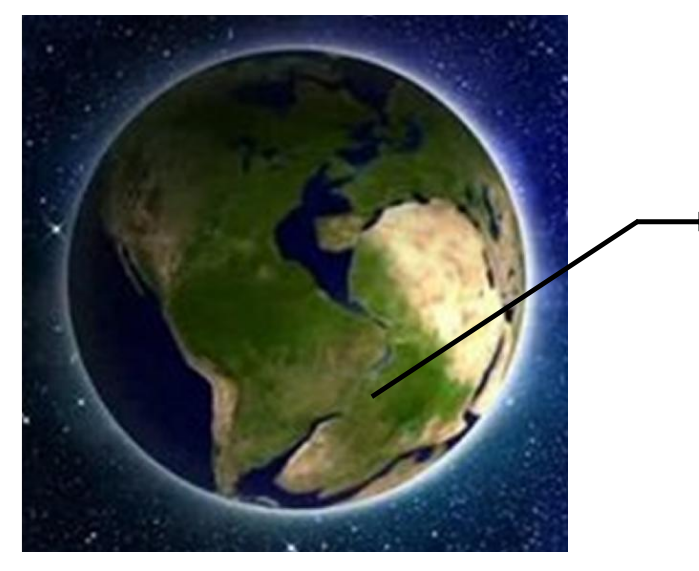

(a)

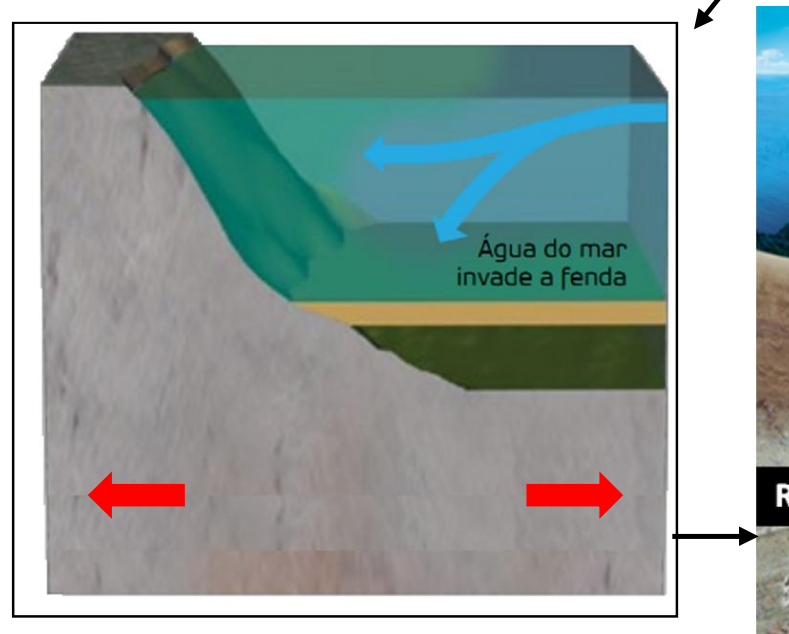

(c)
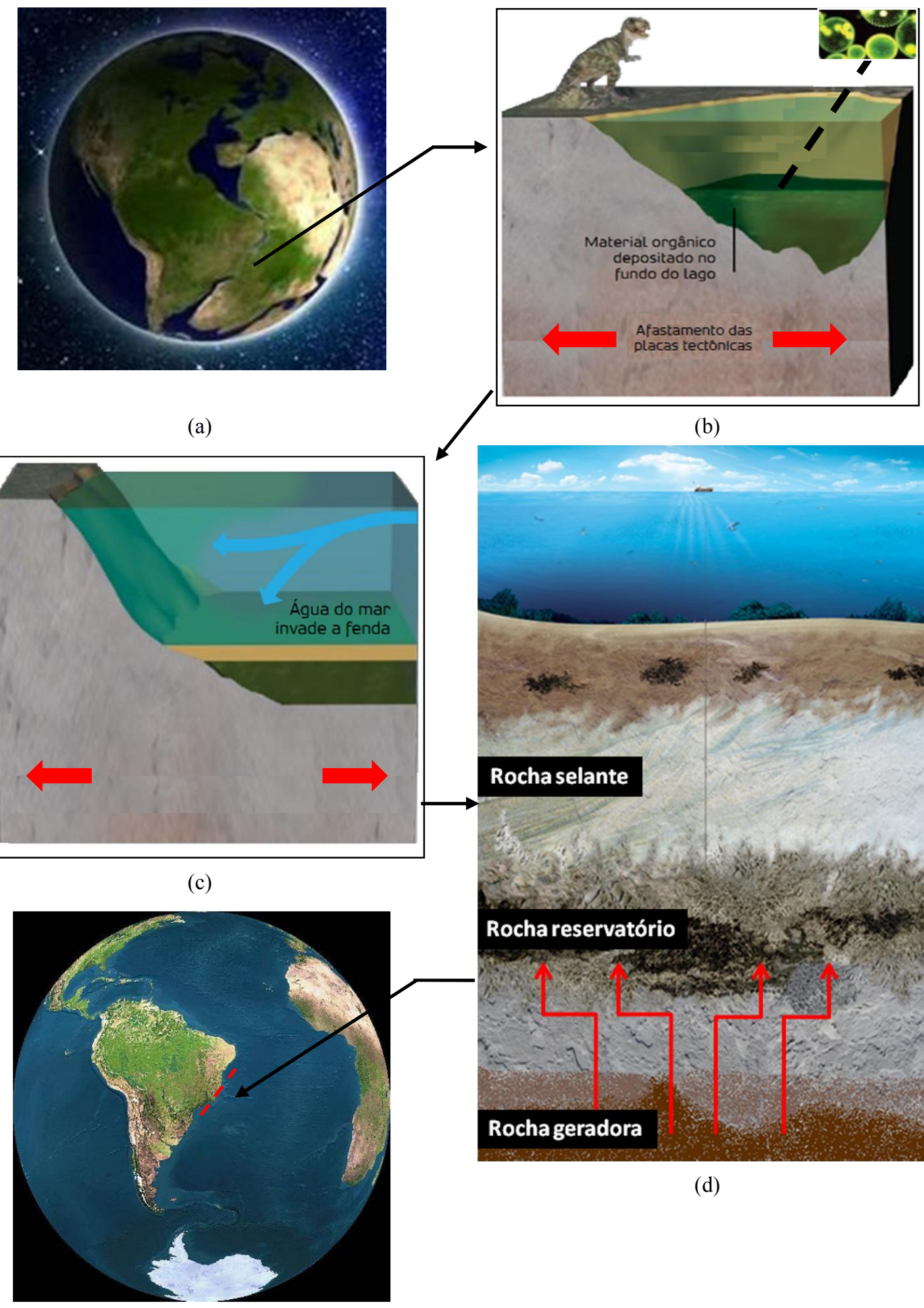

(b)

\section{Rocha selante}

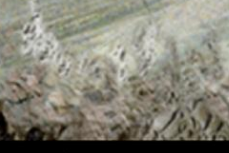

Rocha reservatório

(e)

Figura 2-6 - Formação do petróleo do pré-sal no Brasil: (a) Supercontinente Gondwana; (b) Grandes lagos originados do afastamento das placas tectônicas; (c) Invasão de água salgada do mar; (d) Configuração adequada para a formação de campos de petróleo e; (e) Formação completa do Atlântico Sul e bacias brasileiras.

Fonte: Modificada de Christante (2009). 


\subsection{FLUÊNCIA NOS EVAPORITOS}

Os fenômenos de fluência e plasticidade foram conhecidos, inicialmente, através do estudo do comportamento dos metais. Baseados nestes estudos, modelos físicos e matemáticos que tratam da fluência foram desenvolvidos e são utilizados até hoje. Outros materiais apresentam o mesmo tipo de comportamento de deformação lenta dependente do tempo, como os materiais poliméricos, betuminosos, plásticos, os concretos submetidos a altas temperaturas e os evaporitos. Em função dos resultados experimentais, os modelos baseados nos metais têm sido adaptados aos diversos materiais (GRAVINA, 1997).

A fluência ou creep é, portanto, uma deformação lenta e progressiva dependente do tempo, que pode ocorrer em materiais submetidos a tensão constante (FJAR et al., 2008). Geralmente é descrita em termos de taxa ou velocidade de deformação, dada pela Equação 2$1:$

$$
\dot{\varepsilon}=\frac{d \varepsilon}{d t},
$$

onde:

$\dot{\varepsilon}$ é a taxa de deformação ou fluência;

$d \varepsilon$ é a variação de deformação; e

$d t$ é o intervalo de tempo.

O sal é um material geológico não usual que ao ser submetido a tensões constantes, apresenta deformações significativas em função do tempo, das condições de carregamento e das propriedades físicas. Ou seja, o sal apresenta comportamento de fluência pronunciada, sendo esta a principal diferença das demais rochas sedimentares (POIATE JÚNIOR; COSTA; FALCÃO, 2006).

Em evaporitos, a fluência é de grande interesse aos geotécnicos devido à perfuração de poços de petróleo em águas ultraprofundas, construções de túneis para acesso a minas, cavernas subterrâneas para estocagem e eliminação de lixo radioativo, e até túneis para finalidades civis. Esse comportamento de fluência nos evaporitos e sua velocidade são influenciados pelas características de viscosidade do material, tensões atuantes, espessura da camada, tempo e a temperatura de exposição, composição mineralógica, teor de água e presença de impurezas (BOTELHO, 2008). 


\subsubsection{Estágios de comportamento de fluência}

A conceituação física da fluência é dividida em duas áreas de pesquisa, no âmbito do micro e do macrocomportamento (GRAVINA, 1997). No campo do microcomportamento, a ruptura da estrutura cristalina de um corpo sólido acontece da evolução de deformações plásticas localizadas. A fluência é, sob este ponto de vista, a evolução com o tempo dessas deformações plásticas. No campo do macrocomportamento, a fluência pode ser explicada por três estágios de comportamento, através da evolução das deformações com o tempo (fluência primária, secundária e terciária). A Figura 2-7 exibe as curvas deformação-tempo e taxa de deformação-tempo, caracterizadas em laboratório por um ensaio de fluência sobre um corpo de prova com características viscoelásticas.

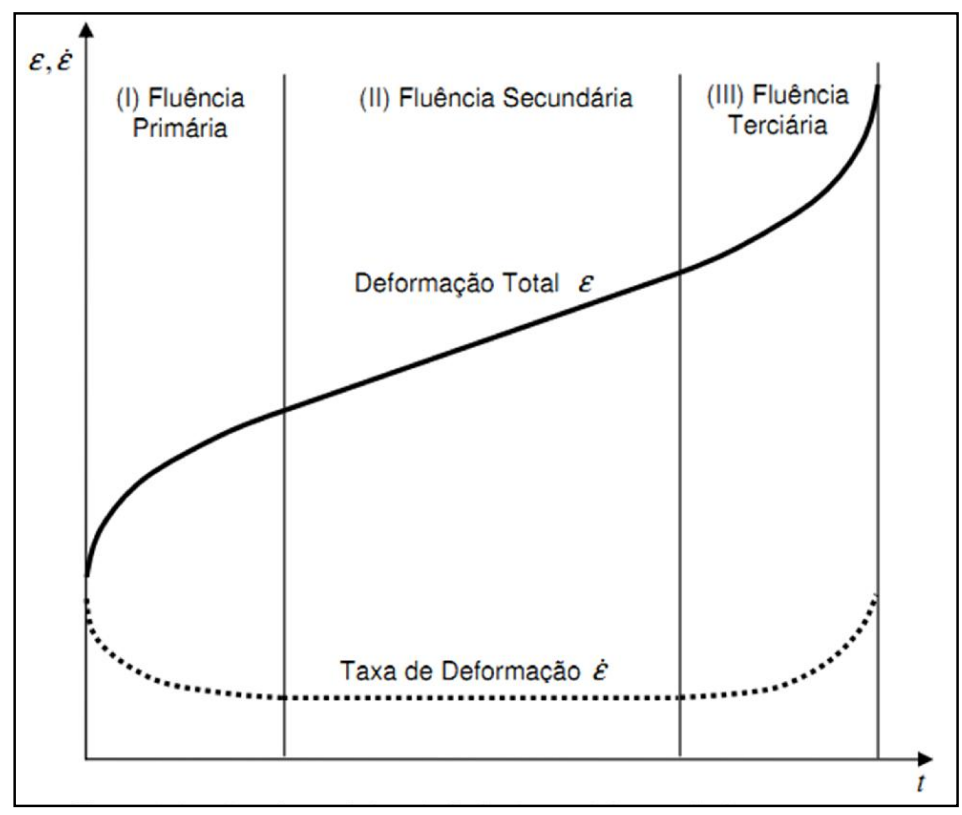

Figura 2-7 - Os três estágios de fluência. Fonte: Costi (2006).

Imediatamente após a aplicação de uma carga constante sobre o material, resulta uma deformação elástica instantânea $\left(\varepsilon_{0}\right)$ (JEREMIC, 1994). Essa deformação inicial evolui para o primeiro estágio chamado de transiente ou fluência primária. Este estágio é caracterizado pela diminuição da velocidade de deformação. Se nesta fase a tensão é reduzida repentinamente a zero, a deformação, eventualmente, reduz a zero também, não restando deformação permanente (FJAR et al., 2008). De acordo com Borges (2008), em rochas evaporíticas a deformação é irreversível, com exceção da halita e gipsita, em que a remoção 
da tensão na fase de fluência primária resulta na reversão da deformação, sem causar danos à sua textura.

O segundo estágio chamado de estacionário ou fluência secundária apresenta como característica principal a constância da velocidade de deformação, logo após a fluência primária (GRAVINA, 1997). A fase secundária é dominante no regime de fluência, nela as deformações ocorridas não são recuperadas totalmente. Ou seja, se a tensão aplicada é reduzida a zero, durante esta fase, a deformação não desaparecerá completamente, resultando uma deformação permanente (FJAR et al., 2008).

A fluência terciária ocorre logo após a fluência secundária em que há um aumento na taxa de deformação do corpo sólido, conduzindo-o rapidamente à ruptura.

O comportamento de fluência de uma rocha depende da magnitude da tensão aplicada e da temperatura. Para tensões baixas ou moderadas, o material pode estabilizar após um período de fluência transiente. Para tensões elevadas, o material pode passar rapidamente por todas as três fases de deformação e, finalmente romper. Ainda, o processo de fluência geralmente acelera com o aumento da temperatura (FJAR et al., 2008). Desta forma, quanto maior a tensão e a temperatura atuantes no material, maiores serão as taxas de deformação por fluência (COSTA, 1984; FJAR et al., 2008; JASTRZEBSKI, 1976).

Outro fenômeno característico em regime de fluência se refere à recuperação das deformações. A Figura 2-8 mostra esse comportamento.

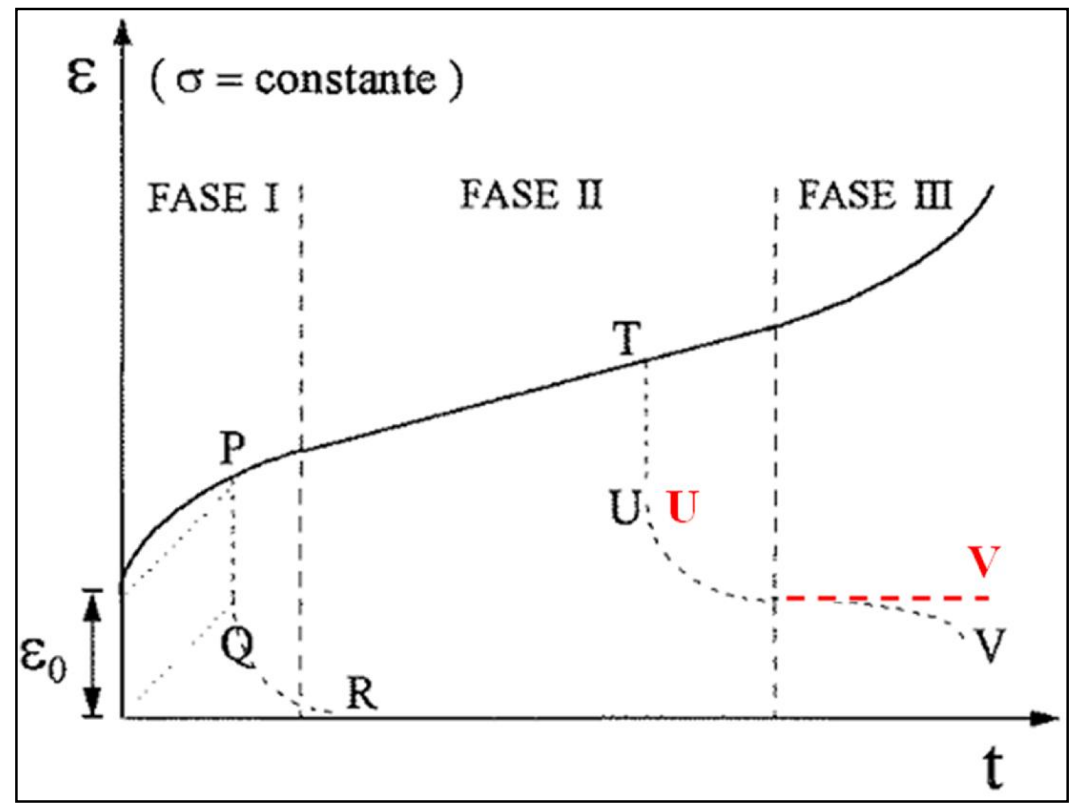

Figura 2-8 - Ensaio de fluência de um material viscoso: comportamento típico. Fonte: Corrigido de Gravina (1997). 
Costa (1984) e Jeremic (1994) afirmam que o corpo sólido irá recuperar sua configuração original e irá seguir a trajetória $\mathrm{PQR}$, caso a tensão seja repentinamente reduzida a zero durante a fase de fluência primária. O trecho PQ refere-se à restauração decorrente da deformação elástica instantânea e o trecho QR representa uma recuperação lenta que tende assintoticamente a zero. Neste trecho, ocorre a recuperação da configuração original do corpo de prova, não restando deformações permanentes.

$\mathrm{Na}$ fase de fluência secundária, a redução súbita do nível de tensões a zero terá como resultado uma recuperação elástica imediata, representada pelo trecho $\mathrm{TU}$, seguida de uma recuperação lenta (trecho UV em vermelho). A recuperação de deformações do trecho UV (em vermelho) tende assintoticamente para uma deformação permanente. O trecho UV foi modificado de Gravina (1997) na Figura 2-8, pois como explicado anteriormente, este trecho tende assintoticamente a um valor residual, e não com aceleração, como mostrado por Gravina (trecho UV em preto).

\subsubsection{Modelos constitutivos de fluência}

Os modelos constitutivos de fluência são utilizados na descrição do comportamento mecânico de alguns materiais, tendo sido inicialmente utilizado nos estudos de metais e posteriormente adaptados para a mecânica das rochas. Segundo Gravina (1997), qualquer relação entre quantidades que envolva o estado de tensões e o estado de deformações em um corpo, incluindo ou não suas derivadas no tempo, é denominada de equação constitutiva. Para o sucesso de um projeto, um dos aspectos mais importantes é a escolha do modelo que melhor represente o comportamento mecânico do material que se pretende analisar. Os modelos constitutivos de fluência podem ser divididos em três grandes grupos: físicos, empíricos e reológicos.

\subsubsection{Leis associadas a processos físicos}

As equações de fluência baseadas em mecanismos físicos representam o comportamento das rochas salinas fundamentado em mecanismos de interação por meio de intervalos de tensões, de taxa de deformação, de estado de deformação, de temperatura e de microestrutura (CAVALCANTE, 2012). 
A partir do início da década de 90, as leis constitutivas de fluência, baseadas em mecanismos físicos, passaram a ser recomendadas na literatura técnica internacional, por representarem o comportamento intrínseco do material (FRAYNE; MRAZ, 1991; MUNSON; DEVRIES, 1991).

Os estudos, com base em processos físicos, fundamentam-se nos três mecanismos predominantes no comportamento de fluência dos materiais: "dislocation climb", "dislocation glide" e um mecanismo indefinido.

\section{Mecanismo "dislocation climb"}

O "dislocation climb" é o mecanismo controlado pelo fenômeno de ativação térmica. $\mathrm{O}$ aumento da temperatura de um corpo sólido ocasiona aumento na oscilação de seus átomos em torno de uma posição de equilíbrio e ocorre a redistribuição molecular da estrutura do material, provocando aumento na capacidade de fluência. Ou seja, a velocidade de fluência é diretamente dependente da temperatura.

Para Munson e Devries (1991), a fluência é controlada pelo "dislocation climb" nos casos em que a temperatura está no intervalo de moderada a alta e o material está sujeito a um baixo regime de tensão desviadora, sendo apresentada na Equação 2-2:

$$
\dot{\varepsilon}=A_{1} \cdot\left(\frac{\sigma}{G}\right)^{n_{1}} \cdot e^{\left(\frac{-Q_{1}}{R T}\right)}
$$

em que:

$\dot{\varepsilon}$ é a taxa de deformação de fluência no regime permanente;

$A_{1}$ é uma constante;

$\sigma$ é a tensão desviadora;

$G$ é o módulo de cisalhamento;

$Q_{1}$ é a energia de ativação;

$R$ é a constante universal dos gases;

$T$ é a temperatura absoluta; e

$n_{1}$ é o expoente de tensão. 


\section{Mecanismo "dislocation glide"}

$\mathrm{O}$ "dislocation glide" controla a fluência estacionária quando o corpo está submetido a altos níveis de tensões. Este mecanismo pode ser representado por uma lei seno-hiperbólica do nível de tensão desviadora aliado a fatores de ativação térmica (MUNSON \& DEVRIES, 1991), como mostra a Equação 2-3:

$$
\dot{\varepsilon}=H \cdot\left(B_{1} e^{\frac{-Q_{1}}{R T}}+B_{2} e^{\frac{-Q_{2}}{R T}}\right) \cdot \sinh \left(\frac{q\left(\sigma-\sigma_{0}\right)}{G}\right)
$$

onde:

$H$ é a função Heaviside;

$\sigma_{0}$ é a tensão desviadora de referência;

$Q_{1}$ e $Q_{2}$ são energias de ativações;

$B_{1}, B_{2}$ e $q$ são constantes.

\section{Mecanismo Indefinido}

Denomina-se mecanismo indefinido pelo fato de não estar associado a nenhum modelo micromecânico, sendo definido empiricamente por ensaios de laboratório, apresentando a mesma forma do mecanismo "dislocation climb". Este mecanismo controla a fluência quando o evaporito está sujeito a baixas temperaturas e baixo regime de tensão.

$$
\dot{\varepsilon}=A_{2} \cdot\left(\frac{\sigma}{G}\right)^{n_{2}} \cdot e^{\left(\frac{-Q_{2}}{R T}\right)}
$$

em que:

$A_{2}$ é uma constante;

$G$ é o módulo de cisalhamento; e

$n_{2}$ é o expoente de tensão.

\section{Duplo Mecanismo de Deformação}

Atualmente existe uma tendência para utilização da lei física de duplo mecanismo de deformação, onde se inclui os mecanismo de fluência "dislocation glide" e mecanismo 
indefinido. Ela se baseia no microcomportamento da estrutura submetida a diferentes condições de temperatura e tensão. Costa, Gonçalves e Amaral (1997), Costa, Poiate Júnior e Falcão (2005) e Poiate Júnior, Costa e Falcão (2006) apresentam a lei física de duplo mecanismo de deformação para a análise de um evaporito com um comportamento elástico/visco-elástico, dada pela Equação 2-5:

$$
\dot{\varepsilon}=\dot{\varepsilon}_{0} \cdot\left(\frac{\sigma}{\sigma_{0}}\right)^{n} \cdot e^{\left(\frac{Q}{R T_{0}}-\frac{Q}{R T}\right)},
$$

sendo:

$\dot{\varepsilon}_{0}$ é a taxa de deformação de referência no regime permanente;

$Q$ é a energia de ativação;

n é o expoente de tensão; e

$T_{0}$ é a temperatura de referência.

\subsubsection{Leis empíricas}

Os modelos empíricos de fluência consistem em equações matemáticas ajustadas para atender o comportamento de um determinado material. Como as equações empíricas normalmente são provenientes do estudo dos metais, a sua utilização na representação do comportamento das rochas necessita de um ajuste das constantes empíricas em função de resultados experimentais. As equações empíricas são subdivididas de acordo com a função matemática governante em: potencial, logarítmica e exponencial.

\section{Lei Potencial}

A equação que representa a lei empírica potencial, utilizada usualmente para representar a fluência primária dos metais, é escrita como:

$$
\varepsilon=B t^{M}, \quad 0<M<1
$$

onde $B$ e $M$ são constantes empíricas determinadas experimentalmente.

A constante $B$ depende de algumas condições particulares do ensaio, como tensão e temperatura. Desta forma, a equação que representa o comportamento de fluência em rochas 
evaporíticas, desenvolvida por Lomenick (1971), pode ser escrita da seguinte forma:

$$
\varepsilon=K \sigma^{c} T^{b} t^{a}
$$

onde:

$\varepsilon$ é a deformação transiente de fluência;

$t$ é o tempo;

$K, a, b$ e $c$ são constantes empíricas.

Esta equação é a mais utilizada na engenharia para a representação do comportamento no estágio transiente de fluência das rochas salinas. Apesar de apresentar explicitamente a temperatura e a tensão, admite apenas tensões e temperaturas constantes.

\section{Lei Logarítmica}

A lei empírica logarítmica também é utilizada na representação da fluência primária dos metais. Sua equação é dada por:

$$
\varepsilon=B \ln (t)
$$

onde $B$ é uma constante empírica determinada experimentalmente. Essa constante depende de algumas condições particulares do ensaio, como tensão e temperatura.

A Equação 2-8 pode ser escrita apresentando a tensão e temperatura de forma explícita, representando a fluência primária das rochas como:

$$
\varepsilon=K \sigma^{c} \ln (t) T^{a}
$$

A Equação 2-9 também admite apenas tensões e temperaturas constantes. A desvantagem desta lei é que a velocidade de deformação tornar-se infinita à medida que a variável tempo $t$ tende a zero (GRAVINA, 1997). Para contornar esse problema, algumas modificações podem ser realizadas na Equação 2-8:

$$
\varepsilon=K \ln (1+B t)
$$

sendo B uma constante obtida experimentalmente.

A lei logarítmica apresenta bons resultados a baixas temperaturas e curtos períodos de tempo. 


\section{Lei Exponencial}

Da mesma forma que as demais leis empíricas apresentadas, a equação que representa a lei empírica exponencial relaciona a fluência primária à tensão, temperatura e tempo, e pode ser escrita como:

$$
\varepsilon=K \sigma^{c} t^{b} e^{\frac{j}{T}}
$$

onde $K, b, c$ e $j$ são constantes empíricas.

Essa lei geralmente é utilizada para modelar o comportamento de fluência dos evaporitos em temperaturas elevadas.

\subsubsection{Modelos Reológicos}

Os modelos reológicos são idealizados para representar de forma macroscópica o comportamento mecânico dos corpos sólidos em termos de tensão, deformação e tempo. Esses modelos podem simular as tensões e deformações de materiais viscoelásticos sob carregamento uniaxial.

De acordo com Gravina (1997), um grande inconveniente dos modelos reológicos é o fato de o efeito da temperatura não aparecer explicitamente em suas equações constitutivas, visto que a fluência de um material viscoelástico é afetada pela temperatura a que é submetido. Desta forma, torna-se necessário considerar a influência da temperatura na fluência dos materiais, incorporando esses efeitos nos parâmetros dos modelos (constantes da mola e de amortecimento).

As seções a seguir apresentam diversos modelos reológicos que podem ser encontrados na literatura (BOTELHO, 2008; GIAMBASTIANI, 2005; GRAVINA, 1997; OLIVEIRA, 2004).

\section{Modelos Básicos}

São dois os modelos que simulam o comportamento mecânico unidimensional dos materiais viscoelásticos de uma forma bastante simples: o sólido elástico linear e o líquido viscoso newtoniano.

O comportamento sólido elástico linear pode ser representado por um elemento de mola (Figura 2-9a) que segue a lei de Hooke. Sua relação constitutiva é dada pela Equação 2- 
12, de modo que a tensão resultante da aplicação da força em um determinado material é diretamente proporcional à sua deformação:

$$
\sigma=E \varepsilon
$$

onde $\sigma$ é a tensão, $E$ é o módulo de elasticidade do material (módulo de Young) que corresponde à constante elástica da mola e $\varepsilon$ é a deformação. Para um material elástico, caso a tensão seja removida, a deformação é totalmente reversível.

O comportamento viscoso linear é apresentado de forma similar ao anterior, utilizando um sistema de amortecedor, como mostra a Figura 2-9b. O elemento amortecedor representa a fluência e sob tensão se deforma gradualmente ao longo do tempo (viscosidade). Caso a tensão seja retirada, a deformação não é revertida. Nesse tipo de material a taxa de deformação ( $\dot{\varepsilon}$ ) é função da tensão $(\sigma)$ e pode ser escrita da seguinte forma:

$$
\sigma=\eta \cdot \dot{\varepsilon}
$$

sendo $\eta$ o coeficiente de viscosidade ou constante de amortecimento do material.

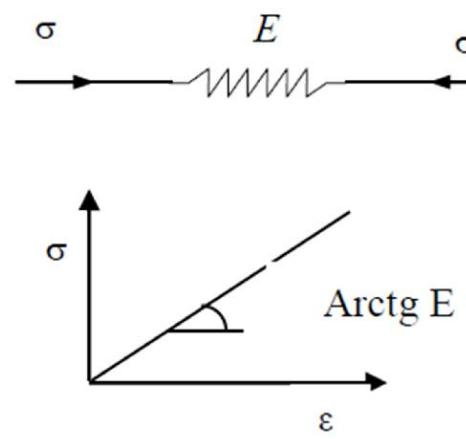

(a)
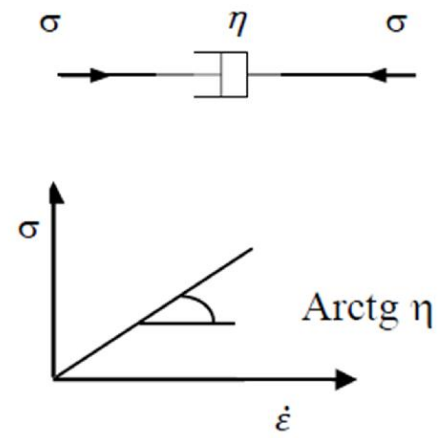

(b)

Figura 2-9 - Modelos Básicos: (a) Modelo de Hooke; e (b) Modelo de Newton. Fonte: Modificada de Cavalcante (2012).

A combinação e a associação desses modelos básicos de mola e de amortecedor formam outros modelos que melhor se ajustam às curvas experimentais dos materiais sujeitos à fluência, tais como os Modelos de Maxwell, de Kelvin e de Burgers.

\section{Modelo de Maxwell}

O modelo de Maxwell é constituído pela associação em série de um elemento de mola e um elemento amortecedor, conforme mostra a Figura 2-10. Nesse tipo de arranjo (em série), 
a tensão $(\sigma)$ é a mesma em ambos os elementos do modelo, e a deformação total $(\varepsilon)$ corresponde à soma das deformações de cada elemento.

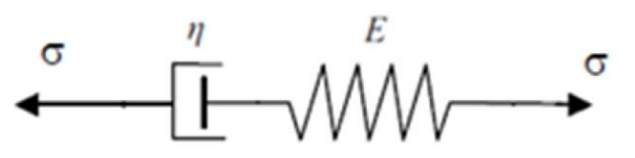

Figura 2-10 - Modelo de Maxwell.

Fonte: Modificada de Oliveira (2004).

As equações constitutivas dos elementos de mola e amortecedor foram apresentadas nos Modelos Básicos. Para a obtenção da equação constitutiva do modelo de Maxwell, devese relacionar a tensão aplicada à deformação total. Percebe-se que:

$$
\sigma=\sigma^{e}=\sigma^{v}
$$

onde, $\sigma^{e}$ e $\sigma^{v}$ correspondem às tensões nos elementos de mola e amortecedor, respectivamente, e $\sigma$ corresponde a tensão total do modelo.

Ainda:

$$
\varepsilon=\varepsilon^{e}+\varepsilon^{v}
$$

sendo, $\varepsilon$ a deformação total, $\varepsilon^{e}$ e $\varepsilon^{v}$ as parcelas de deformação do elemento de mola e do amortecedor, respectivamente.

Derivando a Equação 2-15 em relação ao tempo, tem-se:

$$
\dot{\varepsilon}=\frac{\dot{\sigma}}{E}+\frac{\sigma}{\eta}
$$

A solução da Equação 2-16 considerando $\sigma=\sigma_{0}$ e $\mathrm{t}=\mathrm{t}_{0}$ como condições iniciais, é dada pela equação de uma reta (Equação 2-17), admitindo deformação nula em $t=t_{0}$ a uma aplicação de tensão constante:

$$
\varepsilon(t)=\frac{\sigma_{0}}{E}+\frac{\sigma_{0}}{\eta} t
$$


Na Equação 2-17, a deformação elástica inicial é dada por $\frac{\sigma_{0}}{E}$ e a evolução da deformação com o tempo devido à fluência é dada por $\frac{\sigma_{0}}{\eta} t$. A Figura 2-11 ilustra esta situação.

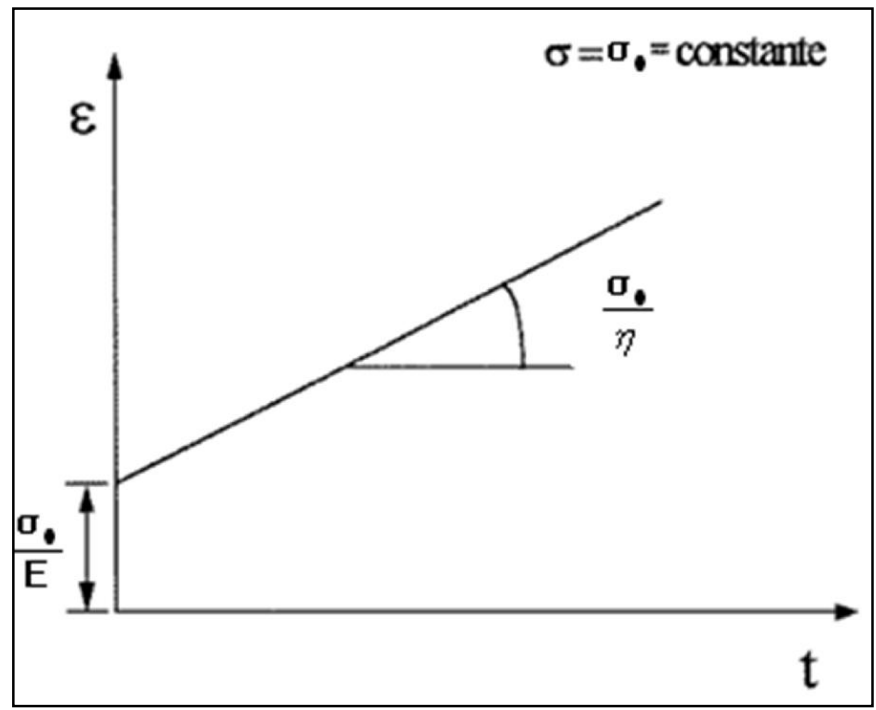

Figura 2-11 - Modelo de Maxwell: ensaio de fluência. Fonte: Modificada de Gravina (1997).

O modelo de Maxwell apresenta algumas restrições para representar situações reais. Este modelo mostra a deformação crescendo linearmente com o tempo, a partir de uma deformação elástica instantânea. O modelo não representa a fluência primária, representando apenas a fluência secundária.

\section{Modelo de Kelvin}

O modelo de Kelvin é formado pela associação de um elemento de mola e de amortecedor, ligados em paralelo (Figura 2-12).

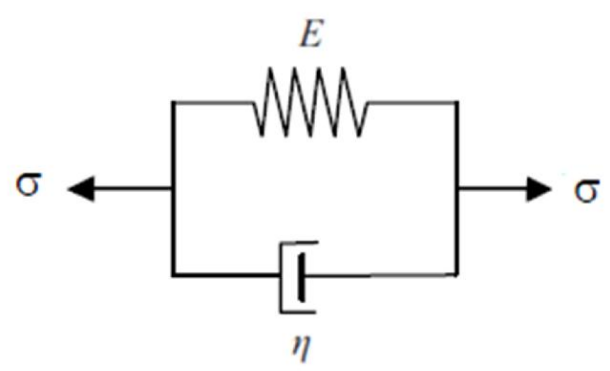


As equações constitutivas dos elementos de mola e amortecedor foram apresentadas nos Modelos Básicos. Como os elementos são conectados em paralelo, as relações de tensões e deformações são dadas por:

$$
\sigma=\sigma^{e}+\sigma^{v}
$$

em que, a tensão total $(\sigma)$ é a soma da tensão de cada elemento ( $\sigma^{e}$ e $\left.\sigma^{v}\right)$.

A Equação de compatibilidade impõe mesma deformação em ambos os elementos:

$$
\varepsilon=\varepsilon^{e}=\varepsilon^{v}
$$

onde, $\varepsilon$ é a deformação total e a mesma em ambos os elementos ( $\varepsilon^{e}$ e $\varepsilon^{v}$ ).

Utilizando as equações 2-12, 2-13, 2-18 e 2-19, obtém-se a equação constitutiva do modelo de Kelvin:

$$
\sigma(t)=E \varepsilon(t)+\eta \dot{\varepsilon}(t)
$$

Resolvendo a Equação 2-20 para tensão constante $\left(\sigma_{0}\right)$, tem-se:

$$
\varepsilon(t)=\frac{\sigma_{0}}{E}\left(1-e^{\frac{-E}{\eta} t}\right)
$$

A representação da fluência primária é apresentada na Figura 2-13, onde a taxa de deformação tende a zero com o tempo, pois a curva em questão é assíntota com a horizontal em um valor de deformação $\frac{\sigma_{0}}{E}$. 


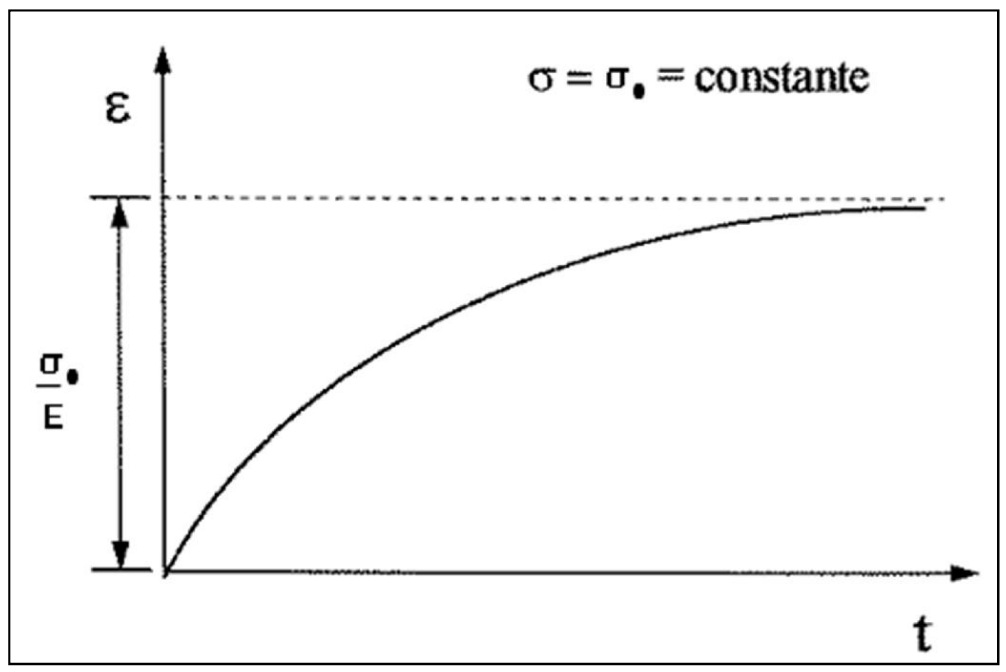

Figura 2-13 - Modelo de Kelvin: ensaio de fluência. Fonte: Modificada de Gravina (1997).

O modelo de Kelvin, assim como o modelo de Maxwell, apresenta limitações quanto à análise do comportamento de materiais viscoelásticos. O modelo não representa a fluência secundária, nem a deformação elástica inicial.

\section{Modelo de Burgers}

O modelo de Burgers ou modelo de quatro parâmetros consiste na associação em série do modelo de Kelvin com o modelo de Maxwell, sendo um modelo composto de quatro parâmetros (Figura 2-14).

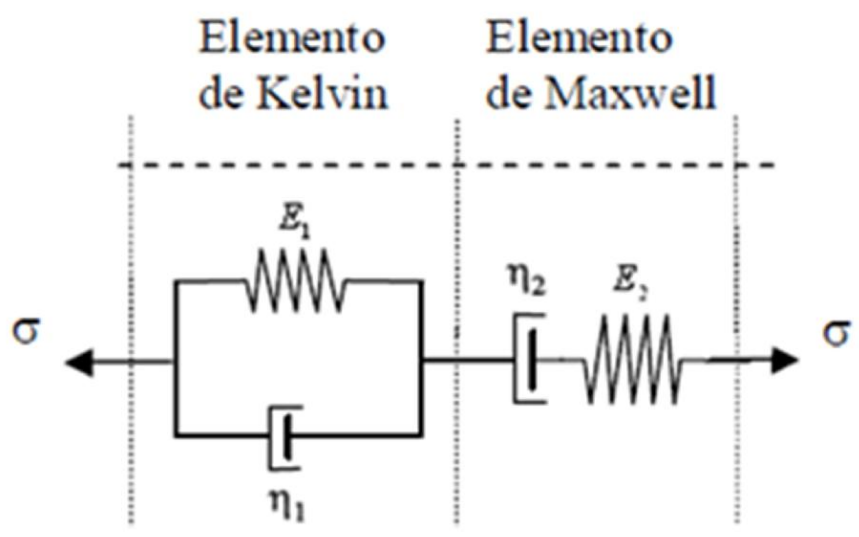

Figura 2-14 - Modelo de Burgers.

Fonte: Modificada de Oliveira (2004). 
A deformação total do sistema do modelo de Burgers é obtida através da soma das deformações dos modelos de Maxwell e Kelvin (Equação 2-22), enquanto que a tensão atuante é igual nos dois elementos (Equação 2-23).

$$
\begin{aligned}
& \varepsilon=\varepsilon_{1}+\varepsilon_{2} \\
& \sigma=\sigma_{1}=\sigma_{2}
\end{aligned}
$$

Substituindo as equações constitutivas de Maxwell (Equação 2-16) e de Kelvin (Equação 2-20), na Equação 2-23 e, fazendo uso da Equação 2-22, obtém-se a equação constitutiva do modelo de Burgers:

$$
\eta_{1} \ddot{\varepsilon}+E_{1} \dot{\varepsilon}=\left(\frac{\eta_{1}}{E_{2}}\right) \ddot{\sigma}+\left(1+\frac{E_{1}}{E_{2}}+\frac{\eta_{1}}{\eta_{2}}\right) \dot{\sigma}+\left(\frac{E_{1}}{\eta_{2}}\right) \sigma
$$

onde, $\eta_{1}$ e $E_{1}$ são constantes referentes aos elementos do modelo de Kelvin, enquanto que $\eta_{2}$ e $E_{2}$ são constantes referentes aos elementos do modelo de Maxwell.

A partir da condição de tensão constante no tempo, com $\sigma(t)=\sigma_{0}$, a equação diferencial pode ser escrita como:

$$
\eta_{1} \ddot{\varepsilon}+E_{1} \dot{\varepsilon}=\left(\frac{E_{1}}{\eta_{2}}\right) \sigma_{0}
$$

Resolvendo a equação diferencial (Equação 2-25), tem-se:

$$
\varepsilon(t)=\frac{\sigma_{0}}{E_{2}}+\frac{\sigma_{0}}{E_{1}}\left(1-e^{\frac{-E_{1} t}{\eta_{1}}}\right)+\frac{\sigma_{0}}{\eta_{2}} t
$$

O comportamento de fluência do material que obedece ao modelo de Burgers é apresentado na Figura 2-15. Este modelo consegue reproduzir a deformação elástica instantânea, a deformação na fase de fluência primária e fluência secundária com velocidade de deformação constante. 


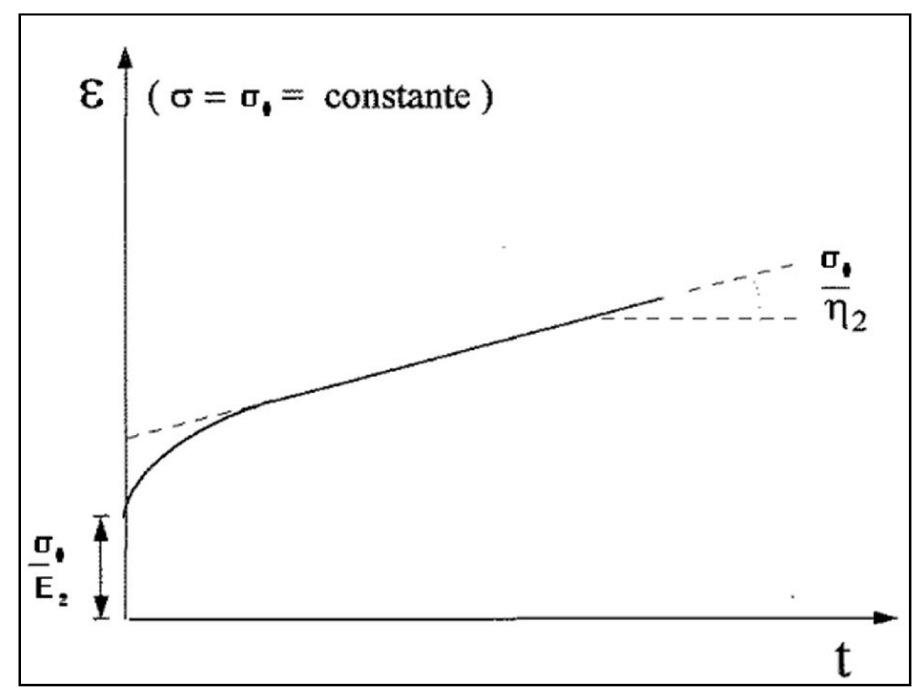

Figura 2-15 - Modelo de Burgers: ensaio de fluência. Fonte: Modificada de Gravina (1997).

De acordo com Costa (1984), o modelo de Burgers, entre os modelos reológicos apresentados, é o que melhor se adaptou às curvas experimentais obtidas em ensaios de laboratório com corpo de prova de evaporitos.

\subsection{PERFURAÇÃO DE POÇOS DE PETRÓLEO EM ZONAS SALINAS}

A presença de rochas evaporíticas em uma determinada área destinada à exploração de petróleo é um fator que aumenta as chances de sucesso exploratório, devido às condições propícias para geração e trapeamento de hidrocarbonetos. Apesar de apresentar excelente característica como rocha selante, devido à sua porosidade e permeabilidade desprezíveis, a presença desses evaporitos pode gerar graves problemas operacionais, se não forem adotados procedimentos específicos para a perfuração da camada de sal.

Além da baixa porosidade e permeabilidade, os evaporitos possuem outras propriedades que os tornam especiais, quando comparados com outros sedimentos, como por exemplo, são solúveis em água, são praticamente incompressíveis, apresentam alta condutividade térmica (fazendo com que o gradiente de temperatura numa seção de sal seja menor do que o da formação acima e abaixo dela) e possuem boa resistência à fratura. Ainda, são praticamente impermeáveis, o que indica que em uma seção homogênea não se espera perda de circulação (POIATE JÚNIOR, 2012). 
A indústria petrolífera precisa tornar cada vez mais rentável o processo de extração do petróleo e gás, reduzindo os custos na perfuração de poços e aumentando a qualidade da análise das informações obtidas antes, durante e após a perfuração e, desta forma, projetar de maneira mais eficiente a perfuração dos poços, evitando aprisionamento da coluna de perfuração e a instabilidade do maciço que podem interromper a produção, gerando prejuízos que não serão recuperados (FREITAS, 2007).

A perfuração de poços de petróleo através de camadas de sal ou a perfuração próxima a estruturas salíferas vem sendo realizada em diversas partes do mundo: Mar do Norte, Golfo do México, Mar Vermelho, Golfo Pérsico, Oeste da África e Brasil (ALVES et al. 2009; BELTRÃO et al. 2009; MARCUSSO et al., 2009).

O poço de petróleo é o elo de ligação entre a rocha reservatório e a superfície. Antes de perfurar um poço de petróleo, deve-se realizar investigações por métodos geológicos e geofísicos, visando a identificar uma área favorável à acumulação de petróleo e indicar o local mais propício para a perfuração. Define-se então o local exato da perfuração, além de qual equipamento deverá ser utilizado, em função da profundidade do poço para alcançar a rocha reservatório.

O principal objetivo da perfuração é atingir os reservatórios de interesse, com o mínimo de comprometimento de suas propriedades permoporosas, de forma a construir um conduto cilíndrico que possibilite a execução da sequência operacional prevista até a conclusão do poço, para a extração de petróleo e gás.

A perfuração de um poço de petróleo é realizada por uma sonda, uma grande estrutura que contém diversos equipamentos responsáveis pela elevação do óleo. Durante a perfuração é necessária a concentração de grande quantidade de energia na broca existente na extremidade de uma coluna de perfuração, a qual consiste de comandos (tubos de paredes espessas) e tubos de perfuração (tubo de paredes finas). Essa energia é transferida às rochas em forma de rotação e peso aplicados sobre a broca, possibilitando a sua ruptura e desagregação em forma de cascalhos, que são removidos do fundo do poço e carreados até a superfície pelo fluxo do fluido de perfuração. Este fluido é injetado por bombas para o interior da coluna de perfuração através da cabeça de injeção e retorna à superfície percorrendo o espaço anular formado pelas paredes do poço e a coluna (THOMAS et al., 2004). Ao atingir determinada profundidade, a coluna de perfuração é retirada do poço e uma coluna de revestimento de aço, com diâmetro inferior ao da broca, é descida ao poço. O espaço anular entre os tubos de revestimento e as paredes do poço é cimentado com a finalidade de isolar as rochas atravessadas, possibilitando o avanço da perfuração com segurança. Após a finalização 
destas etapas, a coluna de perfuração, tendo em sua extremidade uma nova broca com diâmetro inferior ao revestimento, é descida no poço para prosseguir a perfuração (THOMAS et al., 2004). Desta forma, o poço é perfurado em diversas fases, com diferentes diâmetros de broca. Cada fase é finalizada com a descida de uma coluna de revestimento e sua cimentação.

No Brasil, as atividades de perfuração, completação (conjunto de serviços efetuados no poço desde o momento em que a broca atinge a base da zona produtora de produção) e manutenção de poços de petróleo offshore são realizadas por sondas instaladas sobre plataformas fixas, plataformas autoeleváveis, semissubmersíveis ou navios sonda (Figura 216). Para regiões de águas ultraprofundas são utilizadas as plataformas semissubmersíveis ou navios sonda.

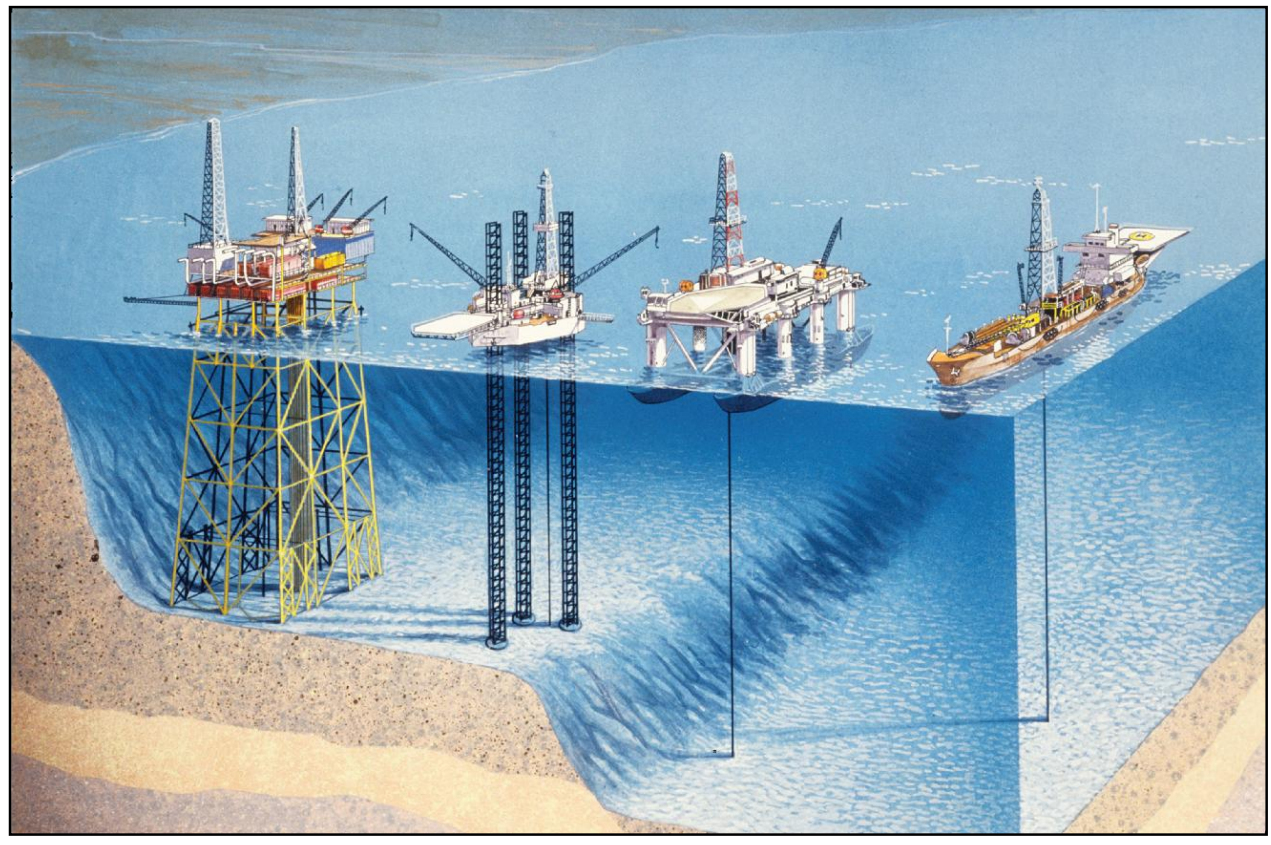

Figura 2-16 - Plataformas (da esquerda para direita): fixa, autoelevável, semissubmersível e navio de produção e estocagem.

Fonte: Morais (2013).

\subsubsection{Fluidos de perfuração}

Os fluidos de perfuração são definidos como fluidos circundantes utilizados em sistemas de perfuração, com o objetivo de proporcionar as condições necessárias na operação (CHILINGARIAN; VORABUTR, 1981). Para Darley e Gray (1988), a conclusão com êxito de um poço de petróleo e seu custo são dependes das propriedades do fluido de perfuração. O custo do próprio líquido de perfuração é relativamente pequeno, mas a escolha das 
propriedades do fluido durante a perfuração influencia profundamente os custos totais. Por exemplo, o número de dias necessários para perfurar a profundidade total depende da taxa de penetração, na prevenção de atrasos causados pelo aprisionamento do tubo de perfuração, da perda de circulação, todos influenciados pelas propriedades do fluido de perfuração.

De acordo com Thomas et al. (2004), os fluidos de perfuração são misturas complexas de produtos químicos sólidos e líquidos, e, por vezes, até gases. Do ponto de vista químico, eles podem assumir aspectos de suspensão, dispersão coloidal ou emulsão, dependendo do estado físico dos componentes. Do ponto de vista físico, os fluidos de perfuração assumem comportamentos de fluidos não Newtonianos, ou seja, a relação entre a tensão de cisalhamento e a taxa de deformação não é constante (MACHADO, 2002).

Diversos fatores afetam os fluidos de perfuração durante a construção do poço, como por exemplo, as variações de profundidade, interação com a formação rochosa do poço, variações de pressão e de temperatura. Desta forma, além de o fluido de perfuração realizar suas funções primordiais, deve ainda apresentar características adequadas para que possa ser utilizado nas diversas formações, garantindo uma perfuração rápida e segura. São elas: ser estável quimicamente, resfriar e limpar a broca, reduzir o atrito entre a coluna de perfuração e o revestimento, manter os sólidos em suspensão quando é parada a circulação do fluido, reduzir a perda do filtrado para as formações, promover a estabilização das paredes do poço, apresentar baixo grau de corrosão e abrasão em relação à coluna de perfuração e a outros equipamentos da coluna de perfuração, além de não ser prejudicial à formação, às pessoas e ao meio ambiente (CHILINGARIAN; VORABUTR, 1981; DARLEY; GRAY, 1988; THOMAS et al.,2004).

Alguns problemas podem ocorrer associados ao tipo de fluido utilizado, como a perda de fluido para a formação, arrombamento do poço pela dissolução dos sais e fechamento do poço. Existem basicamente dois tipos de fluidos recomendados para perfurar formações salinas, que são os fluidos à base de água saturada $(\mathrm{NaCl})$ e os fluidos não aquosos ou sintéticos.

De acordo com Poiate Júnior (2012), os fluidos à base de água saturada são bastante empregados na perfuração de pequenos intervalos salinos, tendo sido muito utilizado na década de 80. Este tipo de fluido apresenta algumas vantagens, como o baixo custo, formulação simples, boa estabilidade reológica e uma facilidade de descarte. Como desvantagens do seu uso, pode-se citar o aumento da solubilidade com a temperatura, não impedem a dissolução de outros sais, possuem elevado potencial de corrosão e difícil logística devido à necessidade de grandes quantidades de sal para atingir a saturação. 
Os fluidos não aquosos ou sintéticos correspondem a fluidos à base de n-parafina ou uma base sintética, como éster, por exemplo. São os mais empregados pelas companhias de petróleo para perfurar espessas camadas de sal (POIATE JÚNIOR, 2012). Como vantagens do uso desse tipo de fluido, tem-se a maior estabilidade térmica, elevada lubricidade, a redução do alargamento do poço e boa estabilidade reológica. Como desvantagens, os fluidos sintéticos apresentam um custo elevado, limitação na utilização de produtos para combater perda de circulação, dificuldade quanto ao descarte (não é permitido que seja feito no mar) e requisito de secador de cascalhos a fim de atender a Legislação Ambiental, em que o fluido agregado aos cascalhos não excedam 6,9\%.

Nos anos de 1990 houve o ressurgimento do interesse em novos produtos e sistemas para fluidos de perfuração, devido aos regulamentos ambientais dirigidos a restringir a presença de materiais tóxicos e não biodegradáveis. Por isso foram formulados os fluidos sintéticos, visto que os fluidos base óleo apresentam alto grau de poluição (CAENN; CHILLINGAR, 1996).

De forma geral, os principais fatores que determinam a escolha de um fluido de perfuração são os tipos de formações a serem perfuradas, a faixa de temperatura, resistência, permeabilidade e poropressão exibida pela formação, qualidade da água e considerações ecológicas e ambientais.

Os diversos evaporitos apresentam diferentes composições químicas, e consequentemente, diferentes solubilidades. Essa característica dificulta a formulação de um fluido que possa impedir as dissoluções. Nesse caso, os fluidos sintético são mais vantajosos, visto que por não terem água livre, não interferem na solubilidade dos sais atravessados, enquanto que os fluidos à base água proporcionam maior dissolução. A literatura demonstra que a maioria das companhias de petróleo apresenta o fluido sintético como o de melhor desempenho (POIATE JÚNIOR, 2012).

\subsubsection{Etapas de revestimento e cimentação}

Sempre houve a preocupação em revestir poços terrestres para proteger suas paredes. Com o passar dos anos esse revestimento evoluiu desde rudimentares alvenarias, adotadas na antiguidade, passando pelas proteções de madeira, tubos de ferro fundido usados até algumas décadas atrás, até chegar ao atual revestimento de tubos de aço especial. O revestimento constitui uma das parcelas mais significativas do custo da perfuração de um poço de petróleo, 
sendo de $15 \%$ a $20 \%$ no mar, podendo chegar a 50\% na terra (THOMAS et al.,2004).

Após a instalação do revestimento, geralmente o espaço anular entre a coluna de revestimento e as paredes do poço é preenchido com cimento (Figura 2-17), de forma a fixar a tubulação e evitar que haja migração de fluidos entre as diversas zonas permeáveis atravessadas pelo poço, por trás do revestimento. Segundo Vlachou e Piau (1997), a cimentação consiste em uma das operações mais importantes realizadas em um poço de petróleo.

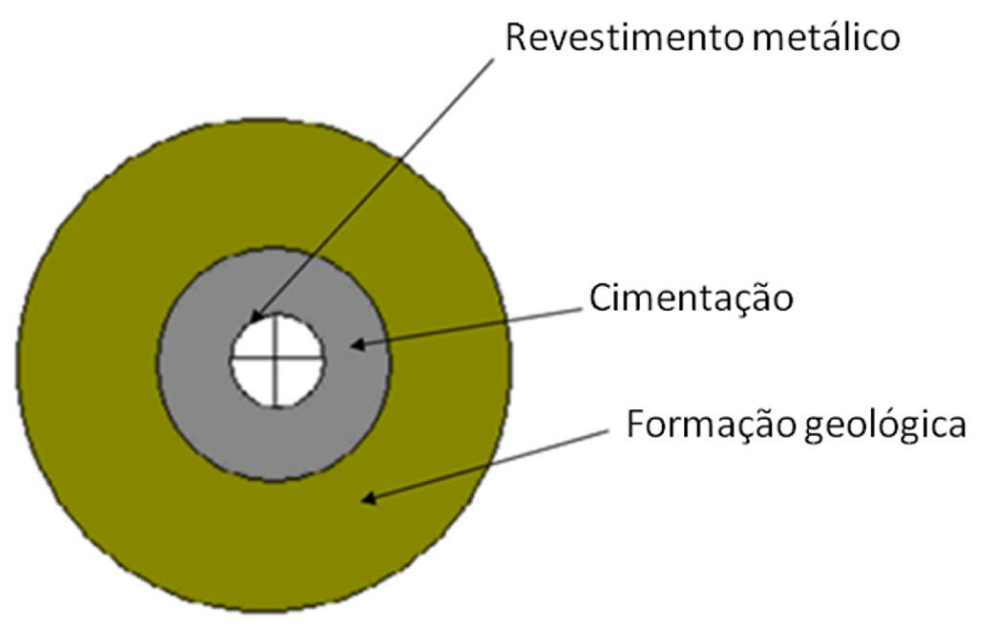

Figura 2-17 - Modelo esquemático: representação da seção transversal de um poço, mostrando o preenchimento Fonte: Freitas (2007). do espaço anular com cimento.

\subsubsection{Revestimento}

O revestimento possui várias funções importantes na etapa de perfuração e completação do poço, como impedir o colapso das paredes do poço e isolar o poço da passagem de fluidos para as formações, minimizando danos ao ambiente (BOURGOYNE JÚNIOR et al., 1986). Desta forma, revestido com as colunas de revestimento, o poço poderá produzir sem riscos na profundidade desejada.

O API (American Petroleum Institute) padronizou procedimentos industriais e operacionais para a fabricação e manuseio de tubos de revestimento, os quais foram internacionalmente aceitos pela indústria de produção de petróleo. O API fornece boletins sobre o desempenho mínimo recomendado. Seu código de série consiste em uma letra seguida por um número, o qual designa a resistência de escoamento mínimo do aço em milhares de psi, como por exemplo para o aço H-40 sua resistência de escoamento mínimo é de 40000 psi 
(276 MPa), enquanto que para o aço P-110 a resistência de escoamento mínimo é de 110000 psi (758 MPa) (BOURGOYNE JÚNIOR et al., 1986). Segundo Thomas et al. (2004), as recomendações e padronizações do API são utilizados no Brasil, embora alguns produtos e procedimentos "não API" também sejam adotados.

A perfuração de um poço de petróleo é realizada em fases, conforme as características das zonas a serem perfuradas e da profundidade final prevista. De acordo com Thomas et al. (2004), o número de fases de um poço é de três ou quatro, podendo chegar a oito, em certos casos. A conclusão de cada fase ocorre com a descida do revestimento e sua cimentação.

O início de poço é a sequência de operações realizadas para assentamento do revestimento condutor, a perfuração da fase seguinte e o assentamento e cimentação do revestimento de superfície. A principal função deste conjunto é conferir a rigidez estrutural ao sistema de cabeça do poço para suportar os esforços transferidos durante a construção do poço pelo conjunto riser e BOP (Blowout Preventer). O riser é um tubo, geralmente constituído de aço, que faz a ligação entre o poço de petróleo, no solo marinho, e as plataformas ou navios, na superfície. No interior do riser passa a coluna de perfuração. O BOP é um equipamento de segurança formado por um conjunto de válvulas que permite fechar o poço evitando acidentes.

A classificação das colunas de revestimento é apresentada por Thomas et al. (2004). O revestimento condutor é a primeira parte perfurada do poço e apresenta maior diâmetro e menor profundidade (10 a 50 metros), com a finalidade de sustentar sedimentos superficiais não consolidados. Esse assentamento se dá por cravação, por jateamento (no mar) ou por cimentação em poço perfurado, com diâmetros típicos de 30", 20" e 13 3/8". Em sequência, tem-se o revestimento de superfície com comprimento variando na faixa de $100 \mathrm{~m}$ a $600 \mathrm{~m}$, o qual visa a proteger os horizontes superficiais de água e previnir desmoronamento de formações inconsolidadas. Ainda serve como base de apoio dos equipamentos de segurança na cabeça do poço, sendo cimentada em toda a sua extensão para evitar flambagem devido ao grande peso dos equipamenteos e dos revestimentos, tendo como diâmetros típicos 20", 18 5/8", 16", 13 3/8", 10 3/4" e $95 / 8$ ".

A finalidade do revestimento intermediário é o de isolar e proteger zonas de alta ou baixa pressão, zonas de perda de circulação, formações desmoronáveis, formações portadoras de fluidos corrosivos ou contaminantes de lama. Sua profundidade de assentamento varia de $1000 \mathrm{~m}$ a $4000 \mathrm{~m}$, sendo cimentado apenas na parte inferior ou, em alguns casos, em um trecho intermediário, e sustentado na superfície por cunhas apropriadas, apoiadas no sistema de cabeça de poço. Tem-se como diâmetros típicos para este revestimento: 13 3/8", 9 5/8" e 
7". Já o revestimento de produção, como o próprio nome indica, é descido com a finalidade de permitir a produção do poço, tendo como diâmetros típicos 9 5/8", 7" e 5 1/2". Tem-se ainda o liner que é uma coluna curta de revestimento, que é descida e cimentada no poço, visando apenas a cobrir a parte inferior deste, com diâmetros típicos de 13 3/8", 9 5/8", 7" e 5 1/2. Sua parte superior fica ancorada um pouco acima da extremidade inferior do revestimento anterior e é independente do sistema de cabeça do poço. Sua versatibilidade e rapidez de operação têm feito seu uso crescente. Quando limitações técnicas ou operacionais exigirem proteção do revestimento anterior, utiliza-se uma completação para a coluna de liner até a superfície, chamada de tie back.

As fases de perfuração e seus revestimentos estão apresentados na Figura 2-18.

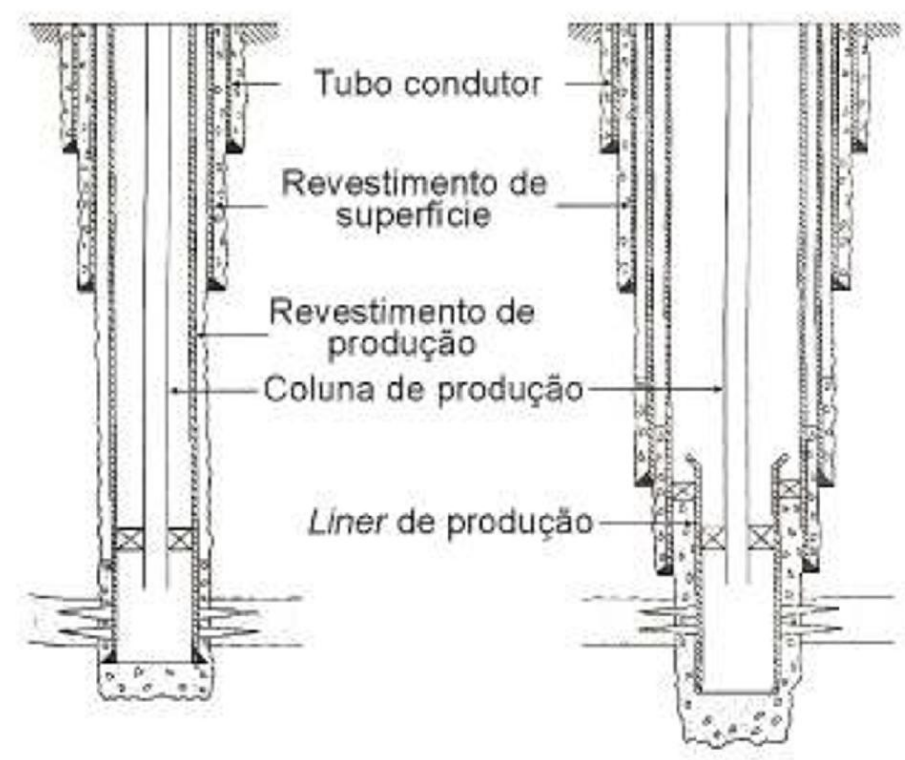

Figura 2-18 - Esquema do revestimento de poços de petróleo.

Fonte: Thomas et al. (2004).

Ao dimensionar uma coluna de revestimento, diversos parâmetros são críticos para o projeto, como: volume de gás que deve ser considerado como tendo invadido o poço, pressão de poros e de fratura da formação a ser perfurada, tipo de fluido que ficará no anular do revestimento e em seu interior, conhecimento prévio sobre as características da área a ser perfurada, possibilidade de perda de circulação, variações de inclinação do poço, posição do topo do cimento e presença de fluidos corrosivos nas formações (THOMAS et al., 2004). 


\subsubsection{Cimentação}

Como já visto anteriormente, a cada etapa de perfuração e descida do revestimento é realizada a operação de cimentação para fixar e isolar o revestimento da formação, protegendo-o contra corrosão e cargas dinâmicas decorrentes de operações no seu interior. A cimentação no espaço anular é realizada mediante bombeio de pasta de cimento, que é deslocada através da própria tubulação de revestimento. Após o endurecimento da pasta, o cimento deve ficar fortemente aderido à superfície externa do revestimento e à parede do poço, nos intervalos previamente definidos (THOMAS et al., 2004).

Existem dois tipos principais de cimentação: a cimentação primária e a cimentação secundária.

\section{Cimentação Primária}

Cimentação primária é o processo de colocação de cimento no espaço anular entre o revestimento e as formações expostas. Desde a sua criação em 1903, o principal objetivo da cimentação primária sempre foi o de fornecer isolamento hidráulico aos poços, garantindo um perfeito controle da origem (ou destino) dos fluidos produzidos (ou injetados). Para atingir este objetivo, um vedante hidráulico deve ser obtido entre o revestimento e o cimento, e entre o cimento e às formações, enquanto que, ao mesmo tempo, evita os canais de fluido na bainha de cimento, como mostrado na Figura 2-19 (NELSON, 1990). Este requisito torna a operação de cimentação primária a mais importante realizada em um poço. 


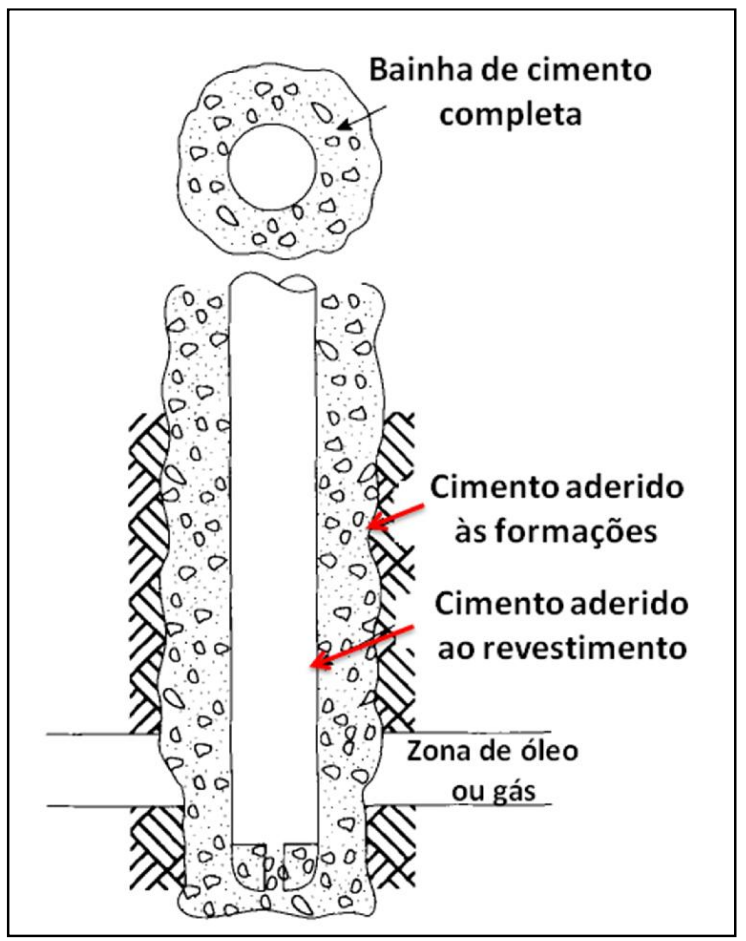

Figura 2-19 - Objetivos da cimentação primária. Fonte: Modificada de Nelson (1990).

Sem o isolamento hidráulico completo em um poço, o mesmo nunca atingirá o seu potencial pleno. O trabalho de reparar uma cimentação defeituosa pode causar danos irreparáveis à formação, além da possibilidade da perda de reservas e taxas de produção mais baixas (NELSON, 1990). A cimentação secundária é realizada quando ocorrem falhas na cimentação primária. Os erros de cimentação podem ocorrer por fatores como densidade incorreta da pasta de cimento, fluxo de gás ascendente, entrada de gás na coluna de pasta, contração volumétrica e aderência insuficiente. Para avaliar a qualidade da cimentação são utilizado perfis acústicos, os quais medem a aderência do cimento ao revestimento e à formação (THOMAS et al., 2004). A Figura 2-20 mostra um esquema onde se observa falha na cimentação. 


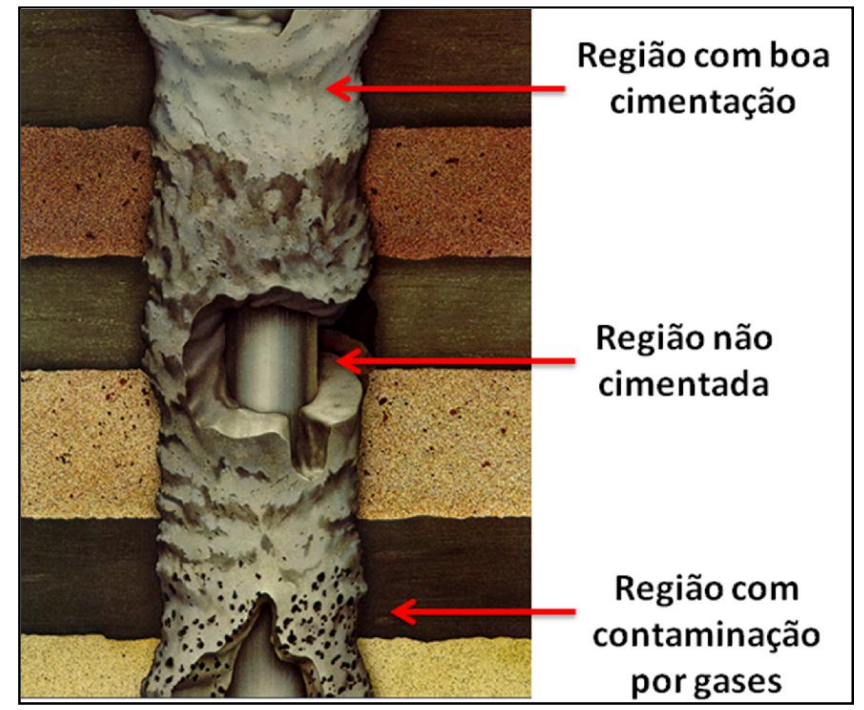

Figura 2-20 - Esquema ilustrativo de poço com falha na cimentação. Fonte: Modificada de Thomas et al. (2004).

\section{Cimentação Secundária}

São assim denominadas as demais operações de cimentação realizadas no poço, excetuando-se a cimentação primária. Destina-se a corrigir falhas ocorridas na cimentação primária, quando necessário. As operações secundárias são classificadas como: recimentação, compressão de cimento ou squeeze e tampão de cimento (THOMAS et al., 2004).

\section{a) Recimentação}

Quando o cimento não alcança a altura desejada no anular, efetua-se uma recimentação, fazendo-se circular pasta de cimento por trás do revestimento, através de canhoneios, que consistem em perfurações realizadas no revestimento.

b) Compressão de cimento ou squeeze

Consiste na injeção forçada de pasta de cimento sob pressão, visando corrigir localmente a cimentação primária, sanar vazamento no revestimento ou impedir a produção de água por zonas atravessadas.

c) Tampões de cimento

Esse processo consiste no bombeio de determinado volume de pasta, que cobre um determinado trecho do poço. Esses tampões localizam-se no interior da tubulação de 
revestimento, impedindo sua comunicação com trechos mais profundos do poço. O seu objetivo é isolar alguma zona de interesse particular, sendo empregados em alguns casos específicos, como na perda de circulação de produção de petróleo por motivo desconhecido, abandono definitivo ou temporário do poço e operações de desvio de poços.

\section{O cimento}

Os cimentos são essencialmente produzidos a partir de mistura de calcário e argila. $\mathrm{O}$ cimento Portland resulta da moagem do clínquer, obtido pelo cozimento até fusão incipiente da mistura de calcário e argila convenientemente dosada e homogeneizada, à qual é adicionada pequena quantidade de sulfato de cálcio (THOMAS et al., 2004).

O cimento Portland é um importante material para a construção civil. Ele também é bastante utilizado nas operações de cimentação de poços de petróleo. As condições a que os cimentos Portland são expostos em um poço de petróleo diferem significativamente daquelas encontrados nas condições ambientes durante as operações de construção. Desta forma, são fabricados cimentos Portland especiais para o uso em cimentação de poços de petróleo. $\mathrm{O}$ cimento Portland é o exemplo mais comum de um cimento hidráulico que se caracteriza pelo processo de pega e endurecimento ao reagir com a água. Esse conjunto de reações é chamado de hidratação e forma produtos que, com o tempo, originam uma massa firme e resistente, a pasta de cimento endurecida (NELSON, 1990). A pega se refere a mudança do estado fluido para o estado rígido. Embora durante a pega a pasta adquira certa resistência, para efeitos práticos, é importante distinguir pega de endurecimento, o qual se refere ao aumento de resistência de uma pasta de cimento depois da pega.

O cimento também tem baixa permeabilidade, e é praticamente insolúvel em água e, portanto, a exposição à água não destrói o material endurecido. Estes atributos são essenciais para o cimento atingir e manter o isolamento hidráulico (NELSON, 1990).

De acordo com Thomas et al. (2004), dos quatro componentes principais apresentados na Tabela 2-4, designados na química do cimento pelas letras C, S, A e F, respectivamente, derivam os compostos mais complexos que determinam as propriedades do cimento, conhecidas como: aluminato tricálcico $\left(\mathrm{C}_{3} \mathrm{~A}\right)$, silicato tricálcico $\left(\mathrm{C}_{3} \mathrm{~S}\right)$, silicato dicálcico $\left(\mathrm{C}_{2} \mathrm{~S}\right)$ e ferroaluminato tetracálcico $\left(\mathrm{C}_{4} \mathrm{AF}\right)$. 
Tabela 2-4 - Composição química do cimento Portland.

\begin{tabular}{cc}
\hline Componentes químicos principais do cimento Portland \\
\hline Cal $(\mathbf{C a O})$ & $60 \%$ a $67 \%$ \\
Sílica $\left(\mathrm{SiO}_{2}\right)$ & $17 \%$ a $25 \%$ \\
Alumina $\left(\mathrm{Al}_{2} \mathbf{O}_{3}\right)$ & $3 \%$ a $8 \%$ \\
Óxido de ferro $\left(\mathrm{Fe}_{2} \mathbf{O}_{3}\right)$ & $0,5 \%$ a $6 \%$ \\
\hline
\end{tabular}

As especificações dos cimentos empregados na indústria do petróleo para cimentação de poços foram estabelecidas pelo API, devido ao fato de as condições a que o cimento Portland está exposto poderem variar radicalmente daquelas experimentadas em aplicações de construção civil. Atualmente são oito classes de cimentos Portland, designadas pelas letras de A a $\mathrm{H}$, organizadas em função da composição química, que devem estar adequadas às condições de uso, como a profundidade e temperatura dos poços (NELSON, 1990; THOMAS et al., 2004):

> Classe A: corresponde ao cimento Portland comum e são utilizadas quando propriedades especiais não são requeridas. Para uso em poços de até 6000 pés $(1830 \mathrm{~m})$

> Classe B: utilizada quando são requeridas condições de moderada a alta resistência ao sulfato, em poços de até 6000 pés $(1830 \mathrm{~m})$;

> Classe C: para poços de até 6000 pés $(1830 \mathrm{~m})$, quando é requerida elevada resistência inicial. Apresenta alta resistência aos sulfatos;

> Classe D: utilizado em profundidades de 6000 pés $(1830 \mathrm{~m})$ a 10000 pés $(3050 \mathrm{~m})$ sob condições de altas pressões e temperaturas moderadamente elevadas. Alta resistência aos sulfatos.

$>$ Classe E: previsto para uso entre 6000 pés $(1830 \mathrm{~m})$ a 14000 pés $(4270 \mathrm{~m})$, sendo próprio para altas pressões e temperaturas. Possui alta resistência aos sulfatos;

$>$ Classe F: projetado para uso a partir de 10000 pés $(3050 \mathrm{~m})$ até 16000 pés $(4880 \mathrm{~m})$, em condições de pressões e temperaturas extremamente altas. Apresenta alta resistência aos sulfatos;

> Classe $\mathrm{G}$ e H: são classes muito similares, utilizadas sem aditivos químicos até 8000 pés $(2440 \mathrm{~m})$, ou com aceleradores e retardadores de pega para as condições previstas para os cimentos das classes de A a E. Os retardadores de pega visam a retardar o início da pega da pasta, mantendo sua fluidez quando a temperatura e pressão são muito altas para o uso do cimento sem aditivos, enquanto que os aceleradores de pega 
têm a função oposta. As classes G e H são as mais utilizadas na indústria do petróleo.

As classes D, E e F são conhecidas como cimentos retardados, para o uso em poços profundos. O retardo é acompanhado por redução significante da quantidade de fases de hidratação mais rápidas $\left(\mathrm{C}_{3} \mathrm{~S}\right.$ e $\left.\mathrm{C}_{3} \mathrm{~A}\right)$, e pelo aumento do tamanho dos grãos de cimento. Uma vez que estas classes foram fabricadas em primeiro lugar, a tecnologia de retardadores químicos teve grande melhoria. As classes $\mathrm{G}$ e $\mathrm{H}$ foram desenvolvidas em resposta a essa melhoria da tecnologia na aceleração e retardo da pasta por meios químicos (NELSON, 1990).

\subsubsection{Problemas na perfuração em evaporitos}

A ocorrência de evaporitos, apesar de ser um bom indício para encontrar reservas de petróleo e da sua utilidade para armazenar lixo tóxico e radioativo, ocasiona muitos problemas do ponto de vista operacional na perfuração. Normalmente, estes ambientes estão associados a um grande número de problemas adicionais de estabilidade de poços e fluidos de perfuração em curto prazo, e cimentação e integridade de revestimentos, em longo prazo.

A fluência associada ao sal é um fator que pode agravar os problemas de perfuração nas rochas evaporíticas. Essa propriedade do sal pode ocasionar o fechamento rápido do poço, podendo causar o aprisionamento da coluna de perfuração de modo irrecuperável. Porém, mesmo depois de o poço ter sido revestido, a fluência pode se manifestar de maneira indesejável, provocando em algumas situações, restrições à passagem de ferramentas pelo revestimento ou até mesmo causando seu colapso, devido aos esforços adicionais impostos por esse fechamento, caso ele não tenha sido dimensionado para isso. Esse efeito é mais pronunciado quando há geração de cargas pontuais devido, por exemplo, a falhas na cimentação (BORGES, 2008). Outros problemas podem ocorrer como o enfraquecimento da parede do poço, decorrente do processo de lixiviação, e alargamento do mesmo devido ao processo de dissolução do sal (Figura 2-21). 


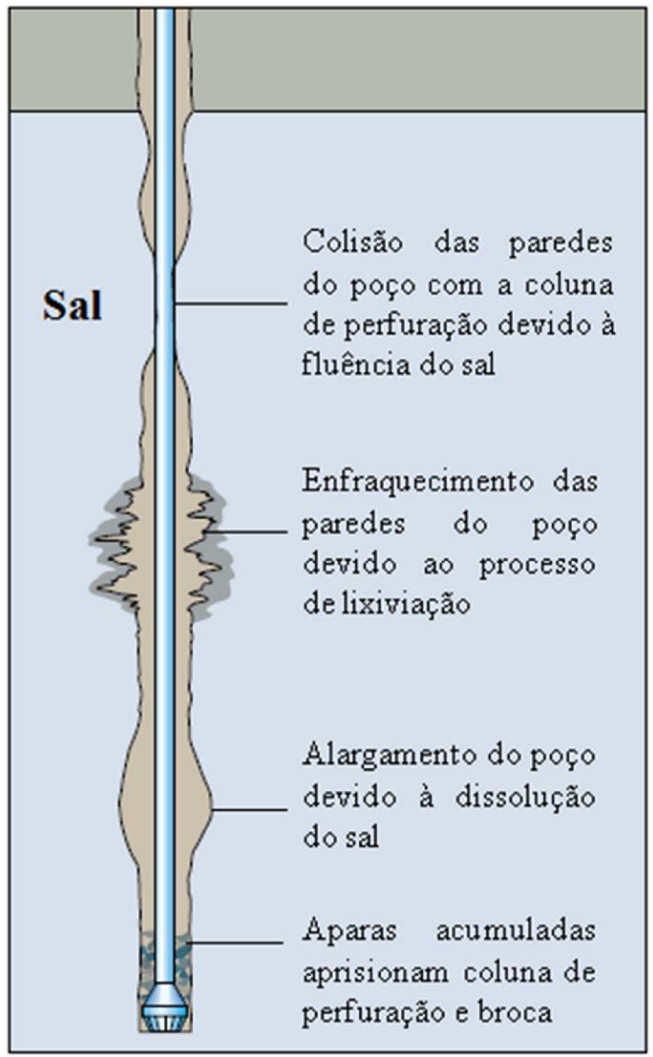

Figura 2-21 - Perfuração em rochas salinas: possíveis problemas.

Fonte: Modificada de Farmer et al. (1996).

A fluência nestas rochas é influenciada sensivelmente pelas variáveis de estado de temperatura e tensões. Desta forma, quanto mais profundas forem as camadas de rochas evaporíticas a serem atravessadas nos poços de petróleo, maiores serão a temperatura e a tensão desviadora atuante (POIATE JÚNIOR, 2012).

Os sais solúveis são materiais geológicos atípicos, devido ao fato de quando submetidos a uma tensão desviadora constante, uma considerável deformação pode ser esperada em virtude desta componente de tensão, do tempo de exposição e de suas propriedades físicas. Apesar disso, nem todos os sais são problemáticos. A mobilidade do sal sob pressões e temperaturas subsuperficiais e sua baixa permeabilidade, o fazem uma eficiente armadilha para os hidrocarbonetos (BORGES, 2008).

Segundo Mohriak, Szatman e Anjos (2008), o sal que apresenta baixa mobilidade, por exemplo a halita, passa a ser uma formação ideal para perfurar, pelo fato de o sal ser homogêneo, ter baixa porosidade, elevado gradiente de fratura (pressão necessária para induzir fraturas em uma rocha a uma dada profundidade) e, em geral, apresentar boa taxa de penetração. No entanto, para a perfuração em sais móveis, como a carnalita, a bischofita e a 
taquidrita, os problemas se multiplicam ao serem comparados a outros tipos de sedimentos. Assim, estes sais possuem maiores taxas de fluência em relação aos sais de baixa mobilidade. Existem ainda, os sais que são essencialmente imóveis, como os carbonatos e sulfatos.

De acordo com Rocha e Azevedo (2007), em função do tipo de fluido de perfuração utilizado, pode ocorrer alargamento excessivo (washout) na parede do poço por dissolução dos evaporitos, causada pela ação desse fluido de perfuração (Figura 2-22).

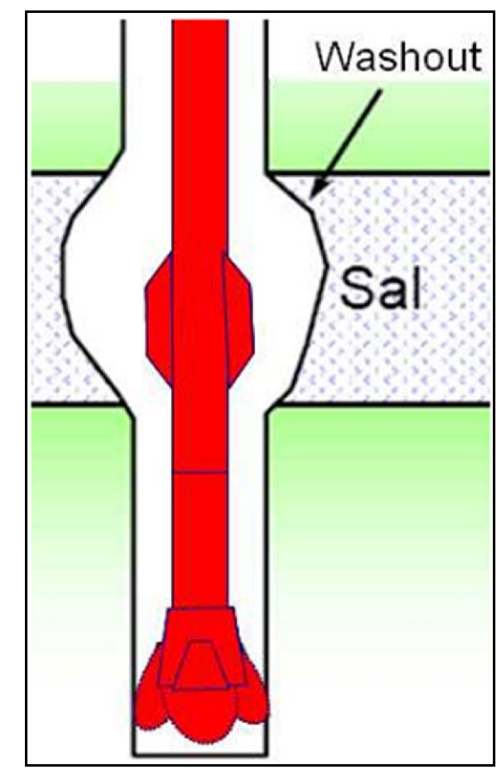

Figura 2-22 - Alargamento excessivo na parede do poço devido à dissolução do sal. Fonte: Poiate Júnior (2012).

Ainda, com a utilização de pesos de fluidos inadequados, a taxa de fluência dos evaporitos também pode conduzir ao alargamento da parede do poço, devido à deformação excessiva dos evaporitos, alcançando o regime terciário de fluência e causando colapso mecânico da rocha em certas regiões. O arrombamento químico (washout) e o mecânico são causados por excesso de deformação por fluência, e acontecem de forma diferente nos diversos evaporitos (POIATE JÚNIOR, 2012).

Segundo Borges (2008), esses efeitos são consideráveis na perfuração de sais altamente solúveis, sendo desprezada nas demais. Desta forma, o perfil caliper (perfil auxiliar que consta do registro das variações do diâmetro nominal da broca usada para perfurar o poço) ao longo do poço pode ficar irregular, prejudicando o carreamento de cascalhos e provocando frequentes prisões de coluna de perfuração por má limpeza do anular. Ainda, quando em uma seção de halita ocorrem intercalações de anidrita, ou outra rocha insolúvel, ocorre uma tendência à formação de batentes na parede do poço (Figura 2-23). Tais batentes 
dificultam a descida do revestimento.

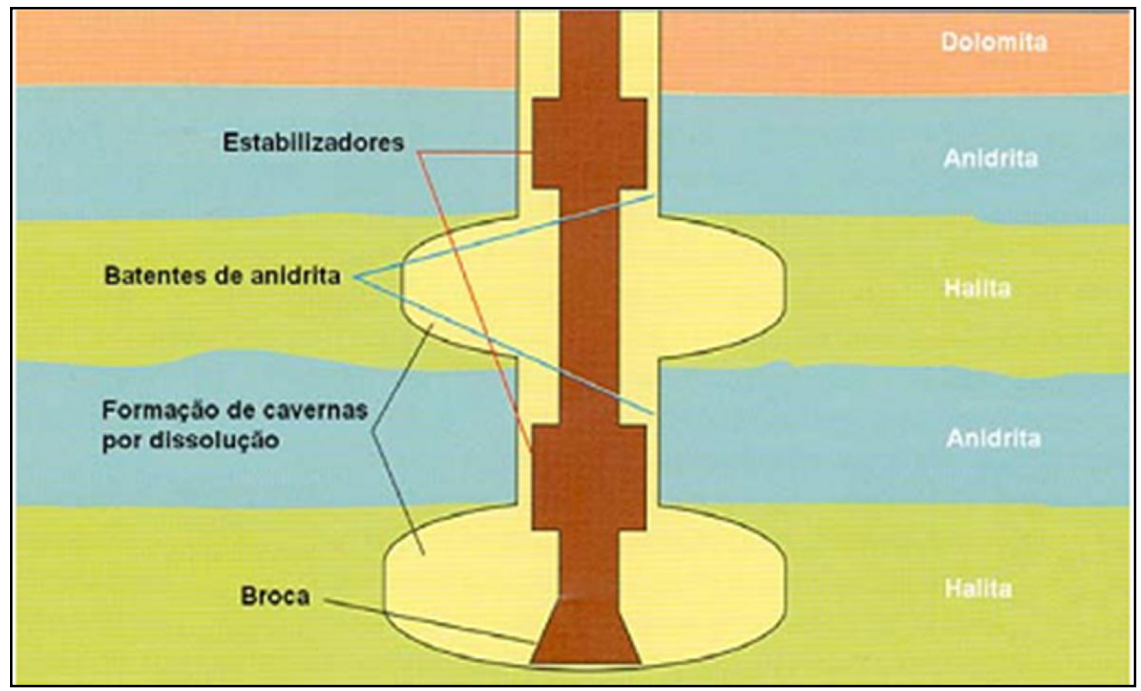

Figura 2-23 - Batentes formados ao longo da perfuração devido à dissolução da halita. Fonte: Falcão et al. (2007).

A halita também pode apresentar taxas de fluência consideráveis, a depender das condições a que esteja submetida. Na Bacia de Campos, já foi constatada uma taxa de fechamento de poço da ordem de 0,05 polegada/h (AMARAL et al., 1999) e na China também foi medida uma taxa de fechamento de 0,03 polegada/hora (CHEN et al. 2004), ambos em halita.

As perfurações no pré-sal e o revestimento dos poços apresentam dificuldades em razão dos vários tipos de sal ao longo da camada, com suas diferentes taxas de deformação, que podem provocar o aprisionamento de tubos durante as perfurações e o colapso da coluna de revestimento (MORAIS, 2013).

Se o espaço anular entre a coluna de revestimento e o sal não é preenchido corretamente com cimento, pode ocorrer uma flexão no revestimento decorrente do carregamento não uniforme provocado pelo fluxo do sal, o qual tende a fechar o orifício (BELTRÃO et al., 2009), como mostrado na Figura 2-24. A depender do nível da flexão do revestimento, pode ocorrer o colapso do mesmo, ou ainda, a coluna de produção instalada no poço não poderá ser retirada, resultando em uma redução e até a perda total de produção no poço. Em geral, o carregamento não uniforme é resultado de uma escolha inadequada do fluido de perfuração seguida de uma cimentação de má qualidade. 


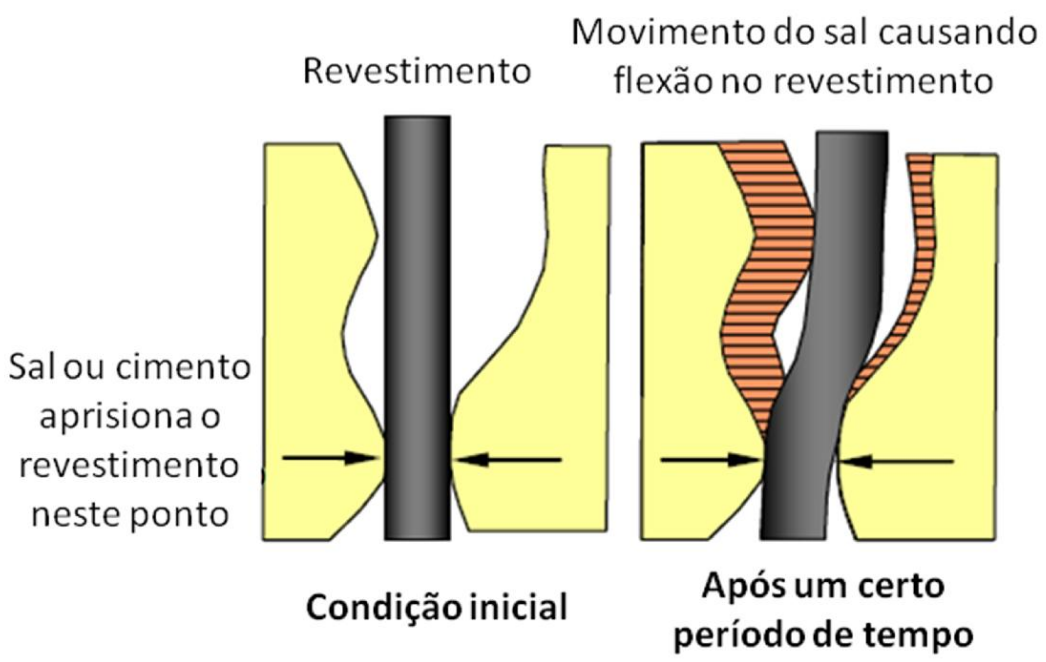

Figura 2-24 - Flexão do revestimento.

Fonte: Modificada de Cheatham Júnior e McEver (1964).

Analisando a situação em que é injetado cimento apenas em uma parte ao redor do revestimento, após o movimento do sal, provavelmente ele forçará o tubo, achatando-o (Figura 2-25). Isso reforça a importância da boa cimentação.

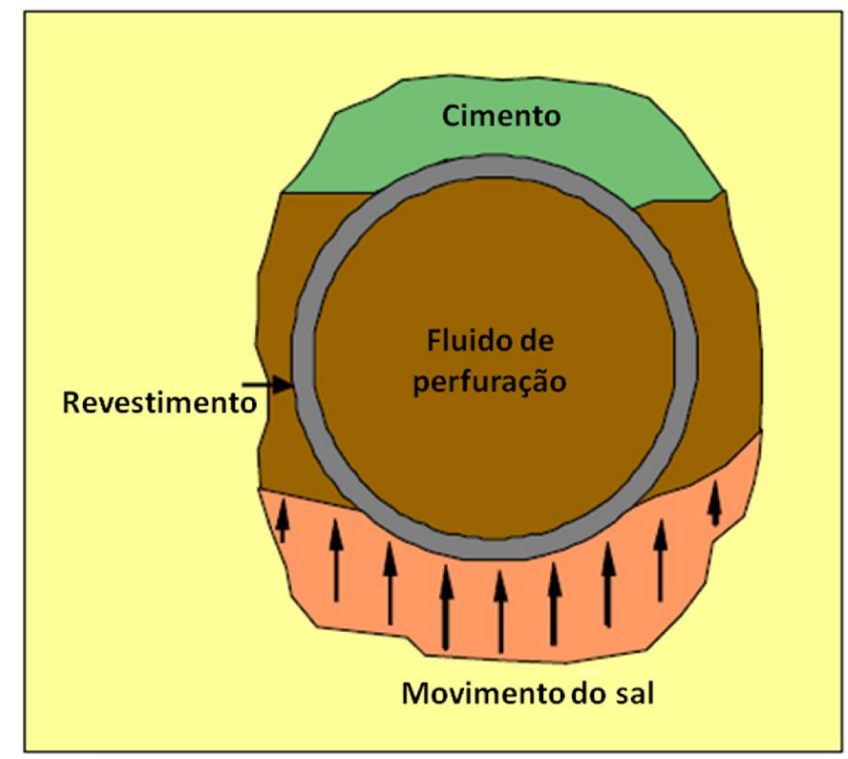

Figura 2-25 - Carregamento não linear no revestimento causado pelo movimento do sal. Fonte: Modificada de Cheatham Júnior e McEver (1964).

Para produzir poços duradouros são necessárias considerações especiais na escolha das brocas, seleção de fluidos de perfuração, escolha da pasta de cimento, correto dimensionamento dos revestimentos específicos para cada poço perfurado, levando em conta 
as peculiaridades da sequência atravessada, correta execução de programas de revestimento e procedimentos de cimentação (BELTRÃO et al., 2009; ROCHA; AZEVEDO, 2007). Deve-se ainda ter um controle da tortuosidade durante a perfuração do sal, reduzindo as chances de problemas relacionados ao colapso do revestimento, executando uma boa centralização do revestimento. 


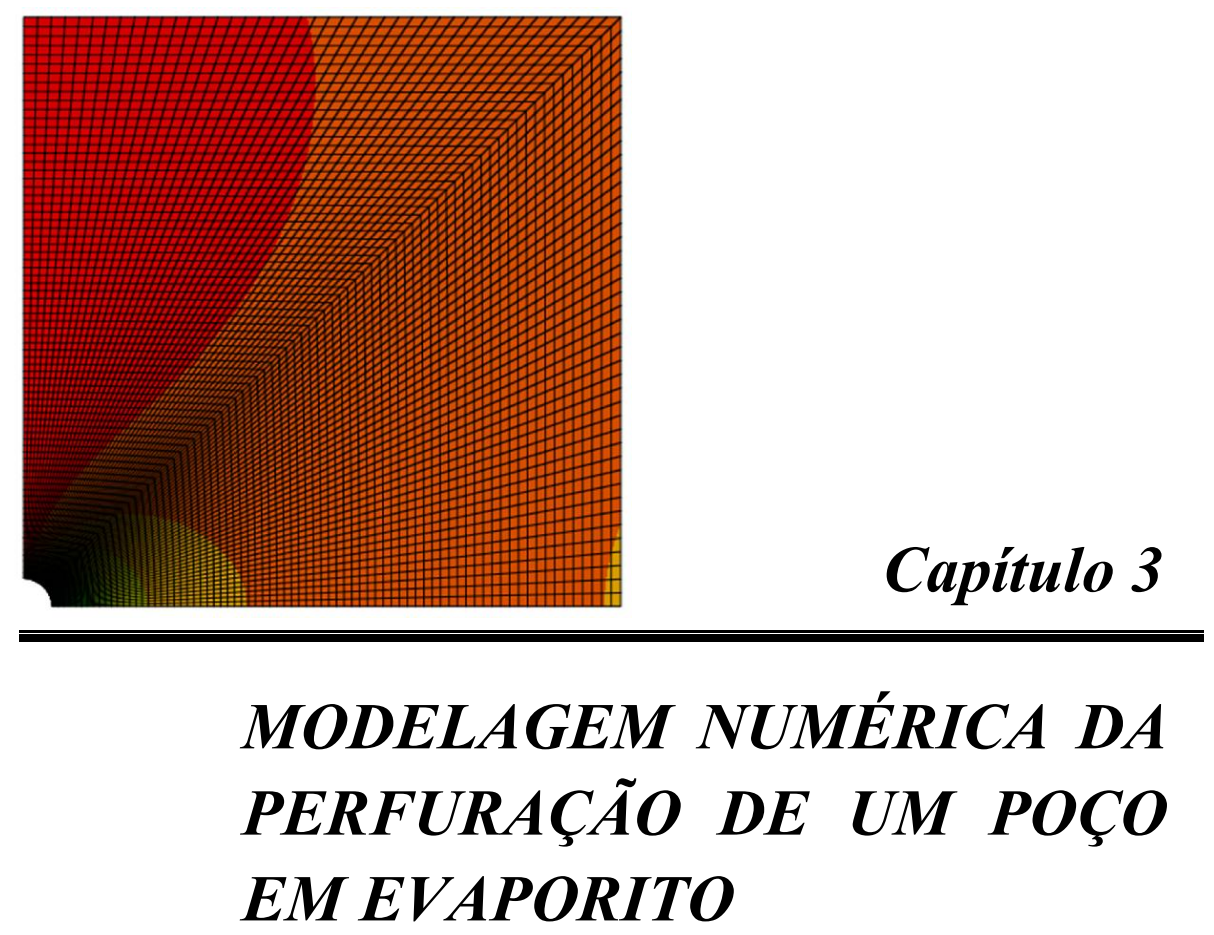




\section{MODELAGEM NUMÉRICA DA PERFURAÇÃO DE UM POÇO EM EVAPORITO}

As ferramentas computacionais têm sido bastante utilizadas para o estudo de problemas de engenharia, apresentando elevado nível de desenvolvimento. $O$ avanço tecnológico proporciona a busca por respostas para problemas cada vez mais complexos. A resposta analítica, na maioria dos casos, não é de fácil obtenção, sendo a simulação computacional uma das alternativas disponíveis para solucionar problemas que inicialmente não possuem solução analítica ou quando essa solução é de difícil alcance.

Respostas rápidas e precisas são fatores de grande importância na simulação de situações reais na área de petróleo e gás. Os problemas que podem ocorrer com a perfuração da camada salina podem ser simulados, de forma a melhorar a estratégia do poço. A análise do comportamento da rocha salina é de grande interesse para diversas áreas, como por exemplo, nas melhorias de processos de mineração, perfuração de poços de petróleo, construção de depósitos subterrâneos para armazenamento de resíduos radioativos e químicos perigosos (JIN; CRISTESCU, 1998).

As simulações numéricas realizadas com base em métodos da mecânica computacional priorizam a utilização de meios contínuos para o estudo do comportamento de materiais, embora desenvolvimentos expressivos existam para meios descontínuos. Assim ocorre, por exemplo, com o Método dos Elementos Finitos (BATHE, 1996). O Abaqus ${ }^{\circledR}$ é um programa de elementos finitos que, do ponto de vista geotécnico, possibilita a simulação mecânica, de fluxo hidráulico e térmico (gradiente geotérmico, por exemplo), apresentando variados recursos e modelos constitutivos para simulação de diversos tipos de materiais.

Inicialmente utilizado para a realização de simulações do comportamento de metais, os modelos do Abaqus ${ }^{\circledR}$ foram adaptados para a simulação de problemas com enfoque geotécnico. A equação de fluência adotada pelo programa está proposta para a simulação do comportamento viscoelástico de metais, podendo ser empregada para a análise do comportamento do evaporito. As análises numéricas deste trabalho são realizadas com o software Abaqus ${ }^{\circledR}$.

Neste capítulo são descritas as simulações computacionais da perfuração de poços de petróleo em evaporitos, utilizando a análise de deformação plana e axissimétrica para prever o comportamento provocado pela fluência do sal até o momento em que é instalado o revestimento. 


\subsection{EQUAÇÕES CONSTITUTIVAS DE FLUÊNCIA NO ABAQUS®}

No Abaqus ${ }^{\circledR}$, o comportamento de fluência (denominado "lei de creep" pelo programa) pode ser dado na forma de duas leis fundamentais, sendo elas, a lei potencial e a lei seno-hiperbólica, ou power-law model e hiperbolic-sine law model, respectivamente.

A lei potencial pode ser empregada na simulação de um comportamento de fluência no estágio primário ou transiente. Desta forma, surge a ideia de adaptação da equação do Abaqus ${ }^{\circledR}$ para simular o comportamento primário de fluência em rochas evaporíticas. A lei seno-hiperbólica pode simular, de forma satisfatória, o comportamento secundário de fluência. $O$ Abaqus ${ }^{\circledR}$ também permite que outros modelos de fluência sejam inseridos pelo usuário (ABAQUS-6.12, 2012).

\subsubsection{Lei potencial (power-law model)}

O modelo da lei potencial está disponível no Abaqus ${ }^{\circledR}$ em duas versões: timehardening e strain-hardening. A primeira é mais apropriada quando o estado de tensão permanece essencialmente constante, enquanto que a versão strain-hardening é mais indicada quando o estado de tensões varia no decorrer das análises.

A taxa de deformação de fluência na versão time-hardening proposta pelo modelo potencial empírico do Abaqus ${ }^{\circledR}$ é expressa por:

$$
\dot{\varepsilon}=A \sigma^{n} t^{m}
$$

onde $\dot{\varepsilon}$ é a taxa de deformação, $\sigma$ é a tensão desviadora, $t$ é o tempo total e, $A, n$ e $m$ são constantes definidas em função da temperatura. Por razões físicas, as constantes $A$ e $n$ devem ser positivas. E o valor de $m$ deve estar entre -1 e 0 .

A versão strain-hardening proposta pelo modelo potencial empírico do Abaqus ${ }^{\circledR}$ é expressa integrando a Equação 3-1 em função do tempo e isolando o tempo $t$ da equação:

$$
t=\left(\frac{\varepsilon(m+1)}{A \sigma^{n}}\right)^{\frac{1}{m+1}}
$$


Inserindo o valor de $t$ na Equação 3-1, resulta na expressão proposta pelo Abaqus ${ }^{\circledR}$ :

$$
\dot{\varepsilon}=\left(A \sigma^{n}[(m+1) \varepsilon]^{m}\right) \frac{1}{m+1},
$$

onde $\dot{\varepsilon}$ é a taxa de deformação, $\varepsilon$ é a deformação de fluência, $\sigma$ é a tensão desviadora e, $A, n$ e $m$ são constantes definidas em função da temperatura.

\subsubsection{Lei seno-hiperbólica (hyperbolic-sine law model)}

A lei seno-hiperbólica simula o comportamento secundário de fluência, levando em consideração o efeito do gradiente de temperatura. Assim, pode ser recomendado o seu uso em situações em que a taxa de deformação estiver diretamente ligada à temperatura. A lei seno- hiperbólica é dada pela Equação 3-4:

$$
\dot{\varepsilon}=A(\sinh B \sigma)^{n} \exp \left(-\frac{Q}{R\left(T-T_{0}\right)}\right)
$$

onde $\dot{\varepsilon}$ é a taxa de deformação, $\sigma$ é a tensão desviadora, $T$ é o valor da temperatura, $T_{0}$ é o valor da temperatura inicial, $Q$ é a energia de ativação ( $\mathrm{kcal} / \mathrm{mol}), R$ é a constante universal dos gases e, $A, B$ e $n$ são constantes do material.

Para a lei seno-hiperbólico, os parâmetros $A, B, n, Q$ e $R$ não podem ser definidos como função da temperatura. Os valores de $A$, para qualquer uma das leis de fluência do Abaqus ${ }^{\circledR}$, a depender do sistema de unidades utilizado, deve ser muito pequeno para as taxas típicas de deformação, mas não tão pequeno a ponto de a solução deixar de convergir (ABAQUS®-6.12, 2012).

\subsection{CONSIDERAÇÕES DO MODELO}

A modelagem numérica da perfuração do poço de petróleo em evaporito foi realizada considerando algumas características com base na estratigrafia típica da Bacia de Santos (Brasil). A Figura 3-1 mostra esquematicamente o perfil geológico analisado. 


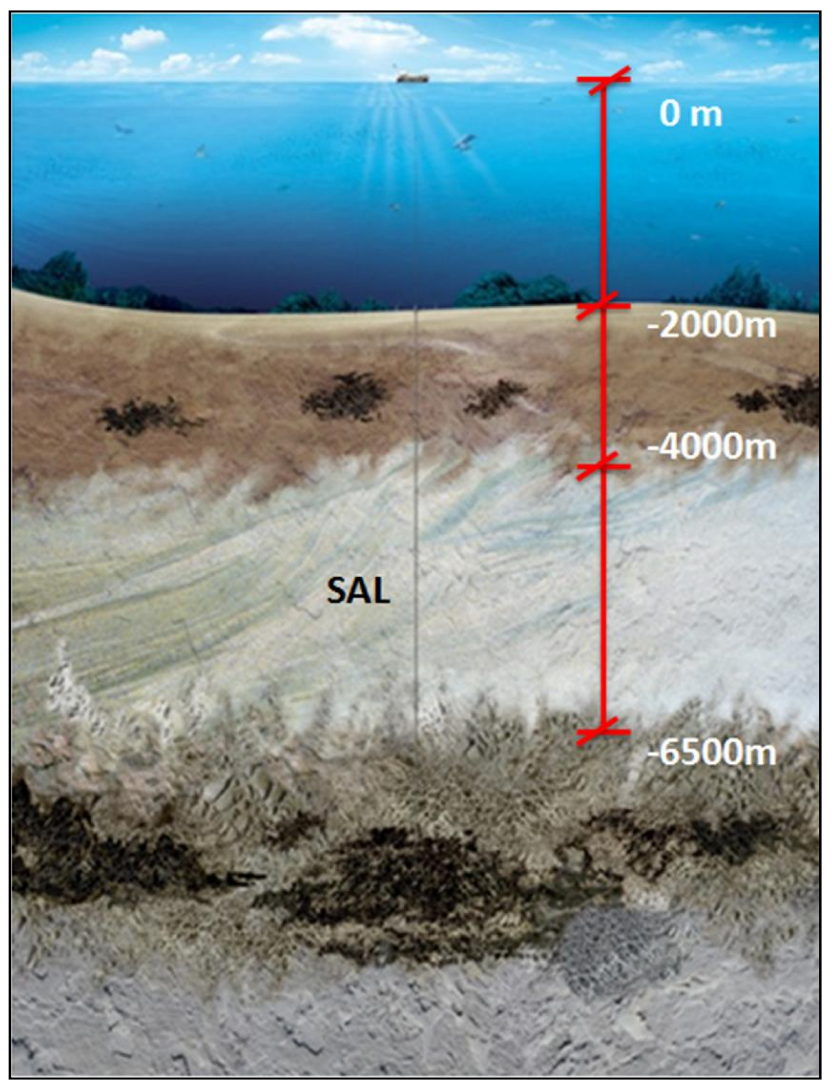

Figura 3-1 - Perfil geológico analisado, fora de escala. Fonte: Modificada de Christante (2009).

Todas as considerações para a análise do modelo plano de deformação e modelo axissimétrico, como a estratigrafia do estudo de caso, dimensões do modelo, parâmetros da rocha e pressões do fluido de perfuração, foram baseadas nos dados utilizados por Botelho (2008). Antes porém, foram realizadas análises para verificação das dimensões e melhor refinamento.

A perfuração de um poço de petróleo com diâmetro de $0,31 \mathrm{~m}$ foi simulada em uma seção 2D situada na camada de sal. A profundidade de estudo do modelo plano de deformação foi de $6000 \mathrm{~m}$ abaixo do nível do mar (Figura 3-2a). Para o modelo axissimétrico, uma espessura de halita pura foi perfurada no intervalo de $6000 \mathrm{~m}$ a $6020 \mathrm{~m}$ abaixo do nível do mar (Figura 3-2b). 


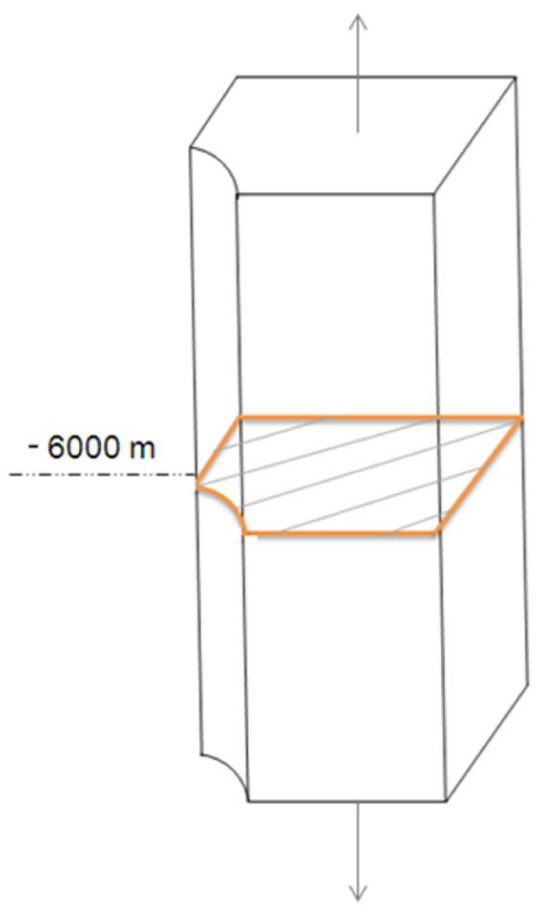

(a)

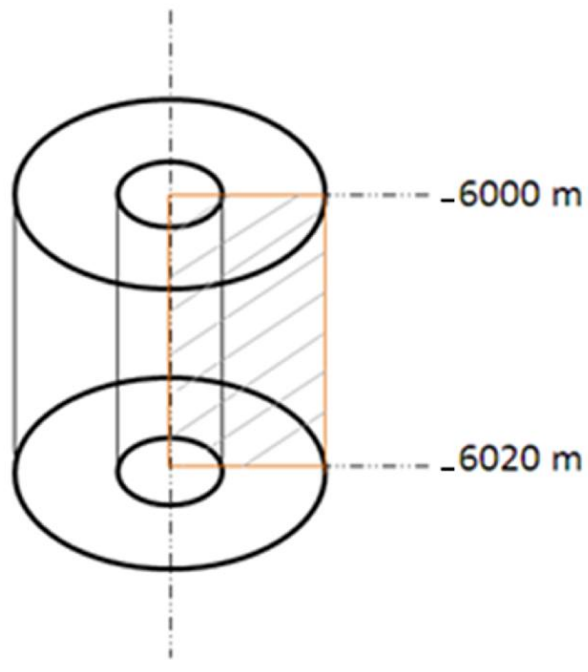

(b)

Figura 3-2 - Representação da seção analisada: (a) modelo plano de deformação em laranja, sem escala. As dimensões não cotadas são infinitas de acordo com a indicação das setas para baixo e para cima; (b) modelo axissimétrico em laranja, sem escala.

Fonte: Modificada de Botelho (2008).

As camadas sobrepostas à região de análise $(6000 \mathrm{~m})$ foram definidas por três regiões: lâmina de água com espessura de $2000 \mathrm{~m}$, "outros estratos" que correspondem às rochas que se sobrepõem à camada salina com $2000 \mathrm{~m}$ de espessura (rochas entre o sal e o mar) e o estrato de sal com $2500 \mathrm{~m}$. Normalmente, uma formação subterrânea tem que suportar o peso das formações sobrejacentes. A tensão vertical $\left(\sigma_{v}\right)$ ou tensão de sobrecarga na parte inferior de uma coluna homogênea de altura $z$ é dada por:

$$
\sigma_{v}=\rho g z
$$

onde $\rho$ é a massa específica e $g$ é a aceleração da gravidade. No caso em que a massa específica varia com a profundidade, a tensão vertical em profundidade $D$ é dada pelo somatório do peso de todas as camadas sobrepostas à seção de análise (FJAR et al., 2008):

$$
\sigma_{v}=\int_{0}^{D} \rho(z) g d z
$$


sendo $\rho$ a massa específica de uma determinada camada com profundidade $\mathrm{z}, g$ a aceleração da gravidade e $D$ a profundidade de estudo.

Para o cálculo da tensão de sobrecarga, utilizou-se uma massa específica para a água do mar de $1019 \mathrm{~kg} / \mathrm{m}^{3}$, valor adotado para todas as simulações e baseado nos valores de referência de Rocha e Azevedo (2007), a qual varia entre 1000 e 1040 kg/m³. A massa específica do sal (halita) e da formação geológica sobrejacente (outros estratos) são respectivamente, $2160 \mathrm{~kg} / \mathrm{m}^{3}$ - Mackay et al. (2007) e $2307 \mathrm{~kg} / \mathrm{m}^{3}$ - Mackay, Inoue e Botelho (2008). O valor da massa específica dos "outros estratos" é aceito como ideal na indústria de petróleo.

O cálculo das tensões até a profundidade de estudo, $6000 \mathrm{~m}$ abaixo do nível do mar, é mostrado na Tabela 3-1, considerando a aceleração da gravidade de $9,81 \mathrm{~m} / \mathrm{s}^{2}$.

Tabela 3-1 - Cálculo das tensões de sobrecarga até $6000 \mathrm{~m}$ abaixo do nível do mar.

\begin{tabular}{cccc}
\hline Tipo de material & Massa específica $\left(\mathrm{kg} / \mathrm{m}^{3}\right)$ & Profundidade $(\mathrm{m})$ & Tensão $(\mathrm{MPa})$ \\
\hline Lâmina de água & 1019 & 0 a -2000 & 20 \\
Outros estratos & 2307 & -2000 a -4000 & 45,3 \\
Estrato de sal & 2160 & -4000 a -6000 & 42,3 \\
Total de tensão & q na profundidade de estudo $=$ & 107,6 \\
\hline
\end{tabular}

Fonte: Modificada de Botelho (2008).

A relação entre as tensões horizontais $\left(\sigma_{h}\right)$ e verticais $\left(\sigma_{v}\right)$ é dada pela Equação 3-7, sendo $K_{0}$ o coeficiente de empuxo em repouso (WARPINSKI; SMITH, 1989):

$$
\sigma_{h}=K_{0} \cdot \sigma_{v}
$$

O coeficiente $K_{0}$ engloba o histórico de tensões no qual se encontram as rochas em estudo. Em uma camada de sal, tectonicamente relaxada, a relação entre as tensões iniciais é geralmente assumida igual para uma determinada profundidade $\left(\sigma_{v}=\sigma_{h}\right)$, ou seja, $K_{0}=1$ (FJAR et al., 2008).

Os parâmetros elásticos utilizados por Botelho (2008) foram extraídos de ensaios com amostras de sal constituídas de halita da mineração de Taquari Vassouras em Sergipe, e tem como valor de módulo de elasticidade e coeficiente de Poisson: $E=2,04 \mathrm{E}+07 \mathrm{kPa}$ e 
$v=0,36$, respectivamente. Os parâmetros elásticos são constantes em toda a camada, ou seja, o meio é homogêneo.

O comportamento de fluência do sal foi simulado utilizando o power-law model do Abaqus ${ }^{\circledR}$. Os valores das constantes foram definidos a partir dos parâmetros determinados por Bradshaw e Macclain, em 1971, para o projeto de Sault Vault, uma mina de sal em na cidade de Lyons, Kansas, Estados Unidos (MEDEIROS, 1999):

$$
\varepsilon=1,3 \cdot 10^{-37} T^{9,5} \cdot \sigma^{3,0} \cdot t^{0,3},
$$

sendo $\sigma$ em psi, $t$ em horas, $T$ em Kelvin e $\mathcal{E}$ adimensional.

Foi utilizado um gradiente geotérmico de $23,6{ }^{\circ} \mathrm{C} / \mathrm{km}$ e $4000 \mathrm{~m}$ de profundidade abaixo do fundo do mar. Após substituir a temperatura encontrada a $4000 \mathrm{~m}$ de profundidade e transformar a Equação 3-8 em uma equação semelhante à do Abaqus ${ }^{\circledR}$ (Equação 3-1), admitindo $\sigma$ em $\mathrm{kPa}$ e $t$ em segundos, tem-se:

$$
\dot{\varepsilon}=2,3939 \cdot 10^{-17} \cdot \sigma^{3,0} \cdot t^{-0,7}
$$

Os valores das constantes $A, n$ e $m$ são $2,3939 \cdot 10^{-17}, 3,0$ e $-0,7$, respectivamente.

O comportamento de fluência da halita é simulado no Abaqus ${ }^{\circledR}$ pelo modelo powerlaw model na versão time-hardening, para todas as análises deste trabalho. Como visto no item 3.1.1, esta versão é utilizada quando não ocorrem variações bruscas de tensões no tempo. Botelho (2008) analisou o problema para as versões time-hardening e strain-hardening, com os mesmos parâmetros, observando pequenas e desprezíveis diferenças entre as análises destas duas teorias.

\subsection{MODELO PLANO DE DEFORMAÇÃO DO POÇO}

O modelo plano de deformação consiste em um plano de $3,10 \mathrm{~m}$ x 3,10 m, com poço de raio de 0,155 m, como mostrado na Figura 3-3, representando um quarto do poço localizado em uma camada de sal. O motivo de analisar a seção de um quarto do poço, referese à redução da malha e, consequentemente, do trabalho computacional. Ainda, na Figura 3-3, os eixos 1, 2 e 3 correspondem respectivamente aos sentidos dos eixos x, y e z. No decorrer deste trabalho será utilizada a representação numérica para os eixos $(1,2,3)$. 
O tamanho do domínio do problema adotado $(3,10 \mathrm{~m})$ corresponde a 20 vezes a dimensão do raio do poço. Nas análises de perfuração em evaporito, Botelho (2008) e Cavalcante (2012) utilizaram o tamanho da malha como sendo 20 vezes o raio do poço, enquanto que Mackay (2011) utilizou um tamanho de 33 vezes o raio do poço. Os valores adotados por esses autores se dá pelo fato de nestas distâncias as tensões induzidas pela perfuração serem as mesmas que as tensões in situ. Tal fato é comprovado neste trabalho no item 3.3.1, para diferentes dimensões do modelo.

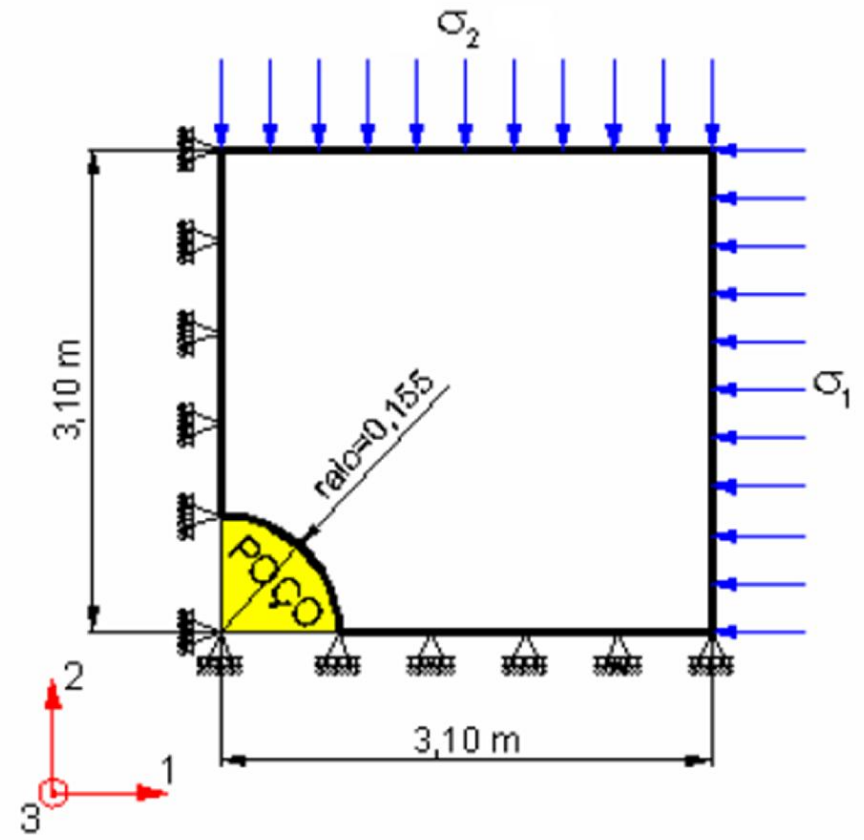

Figura 3-3 - Representação da geometria e das condições de contorno, sem escala. Fonte: Modificada de Botelho (2008).

A Figura 3-3 também apresenta as condições de contorno do modelo, em que estão presentes apoios do primeiro gênero na parte inferior e lateral esquerda, de modo a impedir os deslocamentos nas direções vertical e horizontal, respectivamente. Ainda, na superfície do modelo e na lateral direita podem ser observadas as tensões de sobrecarga atuantes, como explicado no item 3.2. As tensões de sobrecarga apresentadas na Tabela 3-1 foram calculadas para uma profundidade de $6000 \mathrm{~m}$ abaixo do nível do mar e correspondem a 107,6 MPa. Como visto anteriormente, sendo $K_{0}=1$ as tensões verticais e horizontais são iguais para uma determinada profundidade. No plano horizontal também ocorre a isotropia de tensões e, desta forma, na profundidade em análise, tem-se $\sigma_{1}=\sigma_{2}=107,6 \mathrm{MPa}$.

Para simular o estrato salino dois tipos de elementos finitos foram utilizados. $\mathrm{Na}$ região a perfurar, ou seja, do centro ao perímetro do poço foram utilizados elementos 
triangulares lineares (elemento de 3 nós), denominados de CPE3 no Abaqus ${ }^{\circledR}$. Este elemento apresenta as seguintes características:

C: continuum stress/displacement - meio contínuo em análises de tensão/deslocamento;

PE: plane strain - deformação plana;

3: número de nós.

Para o resto da malha foram utilizados elementos quadrilaterais bilineares (elemento de 4 nós) do tipo CPE4, com as mesmas características do elemento anterior, porém com 4 nós. Ainda, foi realizado um maior refinamento na malha próximo ao local a ser escavado, pois nesta região são esperadas maiores variações de tensões, deformações e deslocamentos. Como os elementos triangulares são removidos durante a simulação da perfuração do poço, todos os cálculos são realizados apenas para os elementos quadrilaterais.

A simulação da análise da deformação plana foi dividida em três fases ("steps") que correspondem a cada etapa da simulação. A primeira etapa refere-se ao uso da função geostática do Abaqus ${ }^{\circledR}$, no qual é simulado um equilíbrio entre o estado de tensão e o carregamento externo. A segunda etapa corresponde à escavação do poço, simulando a resposta elástica devido à escavação e à introdução das tensões provocadas pelo fluido de perfuração na parede do poço. Na terceira e última etapa é feita a simulação da fluência, ativando a fase do "creep", para um período de estudo de 30 dias em todas as simulações, tempo máximo de espera para a descida do revestimento.

Os steps são realizados para um determinado fluido de perfuração. Os mesmos procedimentos são realizados levando em consideração os demais pesos de fluido de perfuração. Botelho (2008) realizou as modelagens para 9 pesos de fluidos diferentes. Neste trabalho, as simulações serão realizadas para 5 desses pesos dados em ppg (pounds per gallon), sendo as pressões do fluido calculadas na profundidade de estudo em MPa. Os valores estão apresentados na Tabela 3-2. 
Tabela 3-2- Pressões do fluido de perfuração na profundidade de estudo de 6000m (19685ft).

\begin{tabular}{rc}
\hline Peso do fluido de perfuração & Pressões do fluido de perfuração \\
\hline $\mathbf{9} \mathbf{~ p p g}=\mathbf{0 , 4 7} \mathbf{~ p s i} / \mathbf{f t}$ & $63,8 \mathrm{MPa}$ \\
$\mathbf{1 0} \mathbf{~ p p g}=\mathbf{0 , 5 2} \mathbf{~ p s i} / \mathbf{f t}$ & $70,6 \mathrm{MPa}$ \\
$\mathbf{1 1} \mathbf{~ p p g}=\mathbf{0 , 5 7} \mathbf{~ p s i / f t}$ & $77,4 \mathrm{MPa}$ \\
$\mathbf{1 2} \mathbf{~ p p g}=\mathbf{0 , 6 2} \mathbf{~ p s i / f t}$ & $84,2 \mathrm{MPa}$ \\
$\mathbf{1 3} \mathbf{~ p p g}=\mathbf{0 , 6 7} \mathbf{~ p s i} / \mathbf{f t}$ & $90,9 \mathrm{MPa}$ \\
\hline
\end{tabular}

Fonte: Modificada de Botelho (2008).

\subsubsection{Dimensões do modelo e validação do programa abaqus ${ }^{\circledR}$}

O tamanho da malha adotado corresponde a um produto entre o raio do poço e um determinado valor, de modo a atingir a situação em que a uma certa distância do poço as tensões induzidas pela perfuração sejam as mesmas que as tensões in situ. Como dito anteriormente, Botelho (2008) e Cavalcante (2012) utilizaram o valor de 20 vezes o raio do poço para determinar o dimensão do modelo. Mackay (2011), por sua vez, utilizou um tamanho de 33 vezes o raio do poço.

Devido a esta variação na escolha do tamanho da malha utilizado na simulação da escavação de um poço de petróleo em estado de deformação plana, foram realizados testes para diferentes dimensões da malha. A verificação do tamanho adequado se deu por meio da validação do programa Abaqus ${ }^{\circledR}$, permitindo adotar o tamanho definitivo da malha. Essa validação procura comparar as magnitudes das tensões radiais e tangenciais, após a perfuração, obtidas da solução numérica do Abaqus ${ }^{\circledR}$ com as soluções analíticas de Bradley (1979) e Kirsch (1898) para um meio elástico.

Os tamanhos da malha analisados estão descritos na Tabela 3-3, correspondendo a seis modelos que variam as dimensões de 10 vezes a 35 vezes o raio do poço, de forma a abranger os valores adotados na literatura. Ainda, são apresentados o número de elementos e nós de cada modelo. 
Tabela 3-3 - Modelos analisados para a definição do tamanho do domínio do problema.

\begin{tabular}{cccc}
\hline Modelo & $\begin{array}{c}\text { Tamanho do domínio do problema } \\
(\mathrm{R}=0,155 \mathrm{~m})\end{array}$ & $\mathrm{N}^{\mathrm{o}}$ de elementos & $\mathrm{N}^{\mathrm{o}}$ de nós \\
\hline $\mathbf{1}$ & $10 \times \mathrm{R}=1,55 \mathrm{~m}$ & 3136 & 3235 \\
$\mathbf{2}$ & $15 \times \mathrm{R}=2,325 \mathrm{~m}$ & 6946 & 7098 \\
$\mathbf{3}$ & $20 \times \mathrm{R}=3,10 \mathrm{~m}$ & 12586 & 12790 \\
$\mathbf{4}$ & $25 \times \mathrm{R}=3,875 \mathrm{~m}$ & 19968 & 20225 \\
$\mathbf{5}$ & $30 \times \mathrm{R}=4,65 \mathrm{~m}$ & 29046 & 29356 \\
$\mathbf{6}$ & $35 \times \mathrm{R}=5,425 \mathrm{~m}$ & 39096 & 39459 \\
\hline
\end{tabular}

\subsubsection{Solução de Kirsch}

Kirsch (1898) analisou a abertura de um furo de raio $R$ ao longo da seção transversal constante em um volume infinito, considerando uma análise plana de deformação de um furo em uma placa homogênea, isotrópica e linearmente elástica, submetida a um estado de tensão biaxial. Um ponto localizado na coordenada polar $r, \theta$, próximo ao furo de raio $R$ (Figura 34), tem tensões $\sigma_{r}$ e $\sigma_{\theta}$ dadas por (GOODMAN, 1989):

$$
\begin{aligned}
& \sigma_{r}=\frac{\sigma_{1}+\sigma_{2}}{2}\left(1-\frac{R^{2}}{r^{2}}\right)+\frac{\sigma_{1}-\sigma_{2}}{2}\left(1-\frac{4 R^{2}}{r^{2}}+\frac{3 R^{4}}{r^{4}}\right) \cos 2 \theta, \\
& \sigma_{\theta}=\frac{\sigma_{1}+\sigma_{2}}{2}\left(1+\frac{R^{2}}{r^{2}}\right)-\frac{\sigma_{1}-\sigma_{2}}{2}\left(1+\frac{3 R^{4}}{r^{4}}\right) \cos 2 \theta,
\end{aligned}
$$

onde:

$\sigma_{r}$ é a tensão normal efetiva na direção radial;

$\sigma_{\theta}$ é a tensão normal efetiva na direção tangencial;

$\sigma_{1}$ é a tensão in situ na direção 1;

$\sigma_{2}$ é a tensão in situ na direção 2 ;

$R$ é o raio do poço;

$r$ é a distância a partir do eixo do poço; e

$\theta$ é o ângulo medido no sentido anti-horário do plano 1-2 a partir do eixo 1. 
Substituindo o valor de $r=R$ nas equações acima, obtém-se a variação das tensões sobre a parede do furo.

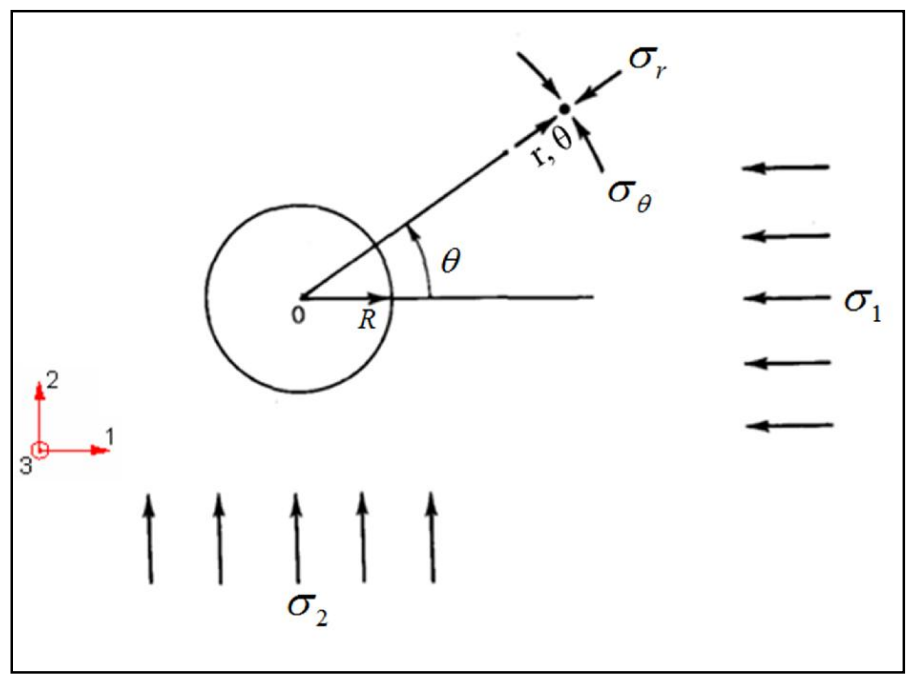

Figura 3-4 - Tensões ao redor do furo circular - solução de Kirsch.

Fonte: Modificada de Goodman (1989).

Realizou-se simulações no Abaqus para os modelos de diferentes dimensões da malha apresentadas na Tabela 3-3, com as condições de contorno representadas na Figura 3-3 e tensão de sobrecarga de 107,6 MPa. A simulação consistiu apenas nas duas primeiras etapas de análise, sem a presença do fluido de perfuração, sendo a etapa geostática e a etapa de escavação do poço, simulando a resposta elástica devido à perfuração. Esses resultados foram comparados com os obtidos das equações de Kirsch, para cada uma das diferentes dimensões. Em todas as simulações aqui apresentadas, os pontos de cálculo têm ângulo zero em relação ao eixo 1, ou seja, as medidas são tomadas ao longo do próprio eixo.

A Figura 3-5 apresenta o resultado da comparação da simulação no Abaqus ${ }^{\circledR}$ e as equações de Kirsch para o modelo 1 (1,55 m x 1,55 m). 


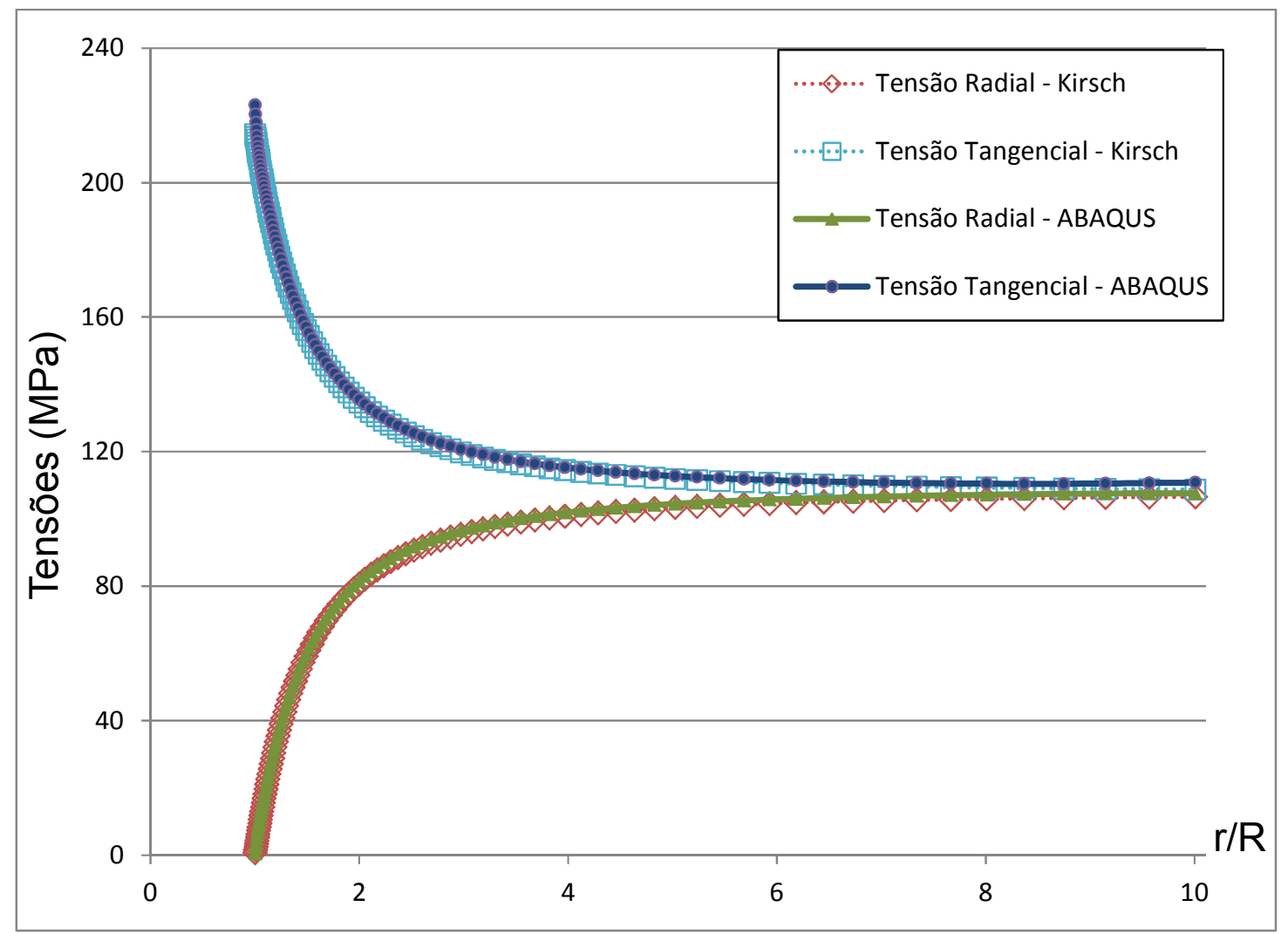

Figura 3-5 - Solução elástica: Kirsch (1898) versus Abaqus ${ }^{\circledR}$ : tamanho de malha 10 x raio.

Neste caso (10xR), as tensões induzidas pela perfuração ainda não são as mesmas que as tensões in situ, devido ao fato de que a dimensão não foi suficiente para que elas se igualassem. Para essa dimensão, as tensões nas regiões mais remotas ao poço apresentam um erro de $1 \%$ em relação às tensões radiais e $2 \%$ em relação às tensões tangenciais..

Para o tamanho de malha do modelo $3(3,10 \mathrm{~m}$ x 3,10 m), tem-se a comparação entre os resultados obtidos no Abaqus ${ }^{\circledR}$ e pelas equações de Kirsch, mostrada na Figura 3-6. 


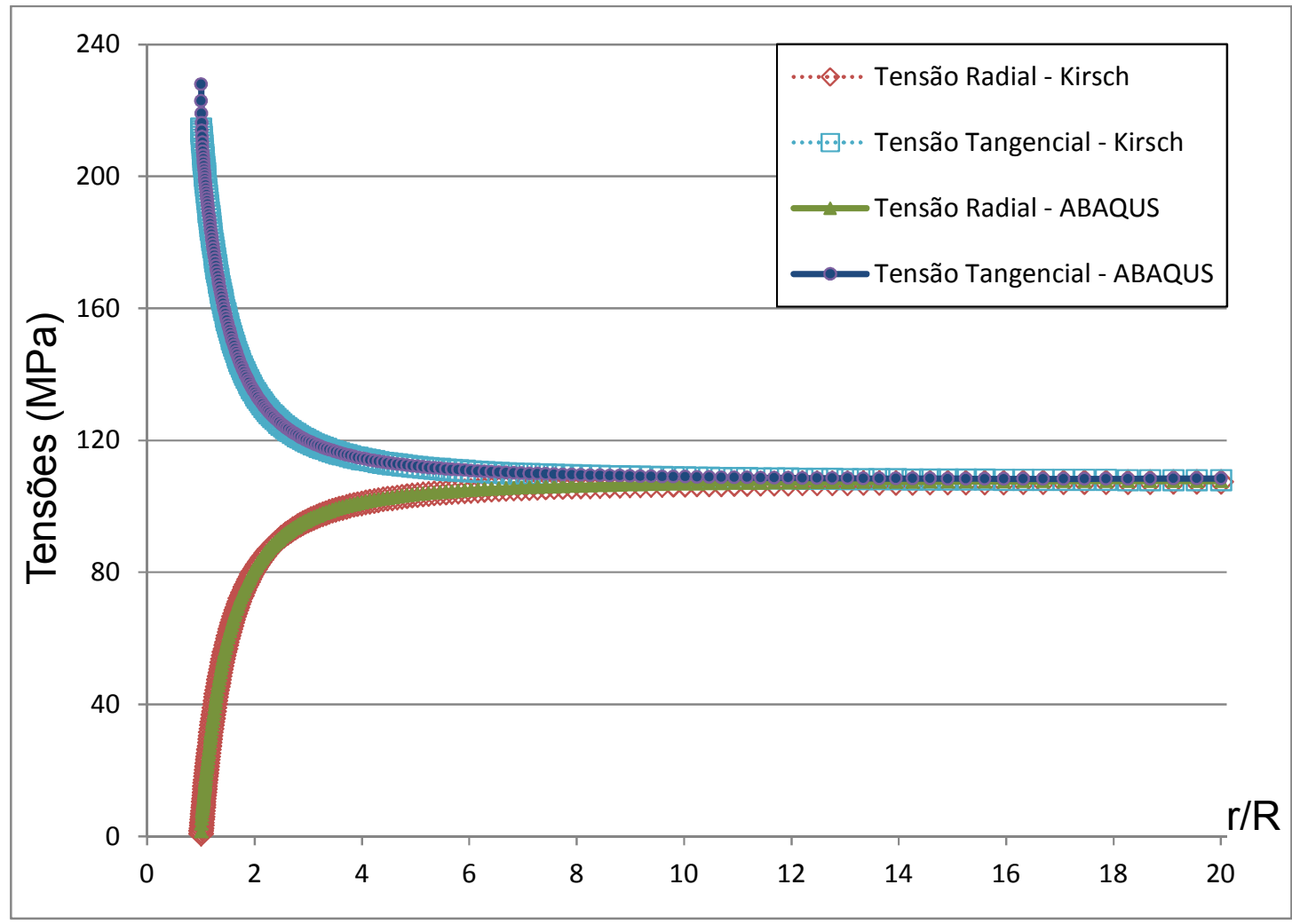

Figura 3-6 - Solução elástica: Kirsch (1898) versus Abaqus ${ }^{\circledR}$ : tamanho de malha 20 x raio.

Observando a Figura 3-6, percebe-se que para este tamanho de malha as tensões decorrentes da escavação, são praticamente as mesmas que as tensões in situ, com erro de $0,2 \%$ para as tensões radiais e $0,5 \%$ para as tensões tangenciais, quando comparadas a solução de Kirsch, o que justifica a utilização por Botelho (2008) e Cavalcante (2012). O modelo 2 (15xR), as tensões ficam bem próximas das tensões in situ, mas não tão próximas quando ao utilizar a dimensão de 20 vezes o raio.

À medida que haja um aumento na dimensão dessa malha é natural que as tensões se igualem cada vez mais as tensões in situ, assim aconteceu para as dimensões de 25, 30 e 35 vezes o tamanho do raio do poço. Mas, se tratando de programa computacional, quanto maior a malha analisada, maior o custo computacional. Devendo portanto, encontrar a dimensão que esteja mais próximo ao esperado com um custo computacional aceitável.

Verificando a dimensão com valor de 35 vezes o raio do poço, Figura 3-7, o último modelo estudado (modelo 6) e o modelo próximo ao utilizado por Mackay (2011), as tensões radiais nas regiões distantes do poço apresentam um erro de $0,08 \%$ em relação à solução elástica de Kirsch, enquanto que para as tensões tangenciais este erro é de $0,16 \%$. 


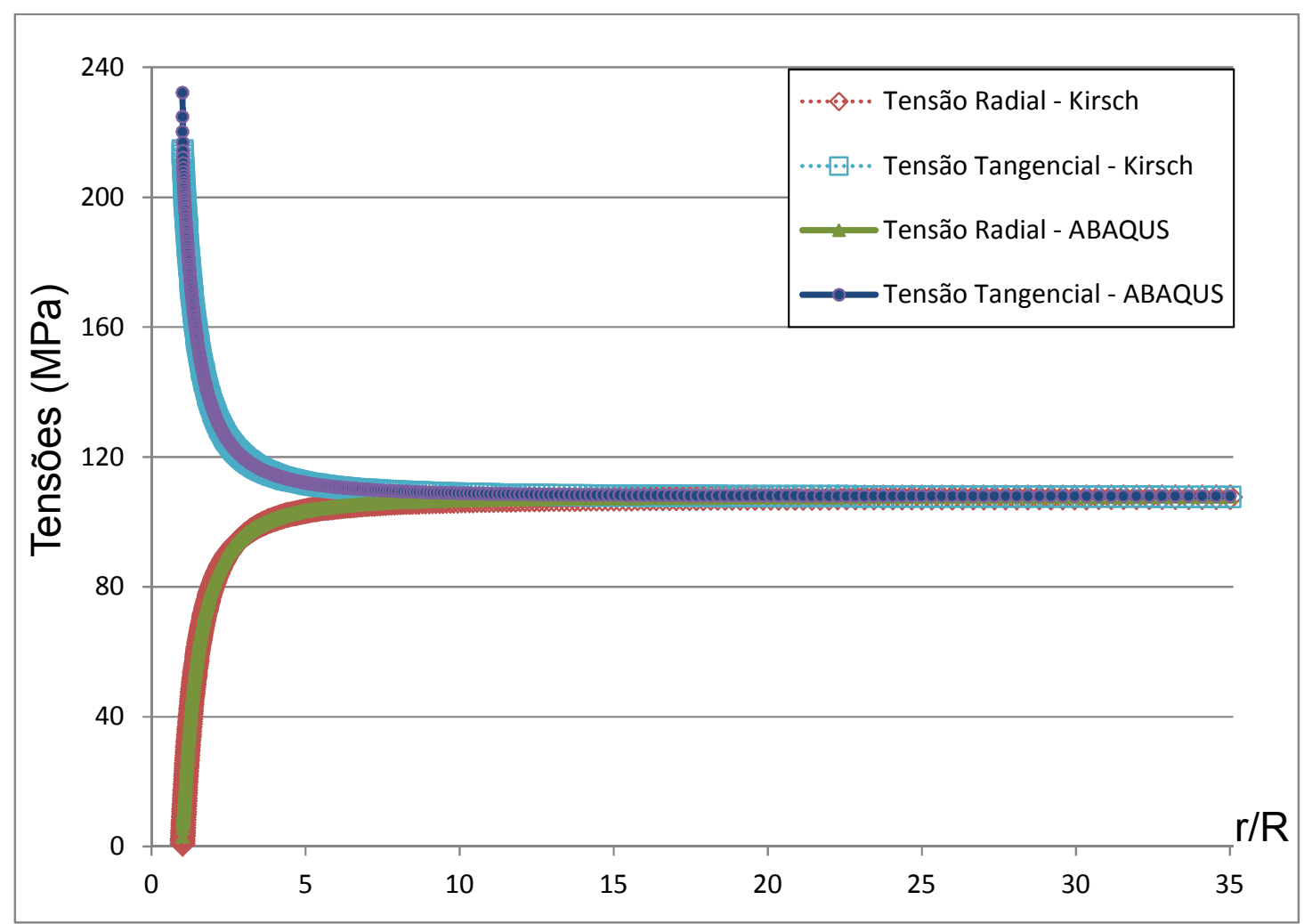

Figura 3-7 - Solução elástica: Kirsch (1898) versus Abaqus ${ }^{\circledR}$ : tamanho de malha 35 x raio.

Desta forma, percebe-se que é adequado o uso do tamanho da malha de 20 vezes o raio do poço, visto que as tensões em posições remotas ao poço seguem uma estabilidade do valor aproximado das tensões iniciais, sendo este valor satisfatório para o problema analisado. Apesar do aumento da malha aproximar cada vez mais o valor dessas tensões, o modelo 3 exige um menor custo computacional. Todas as simulações do modelo plano de deformação são utilizadas para esta dimensão: 3,10 m x 3,10 m.

Ainda, levando em consideração a validação do programa Abaqus ${ }^{\circledR}$ utilizando a solução de Kirsch, observa-se que a tensões radiais são nulas na parede escavada e tendem a um valor correspondente a tensão inicial à medida que se afastam das proximidades do poço. Por outro lado, as tensões tangenciais são maiores nas regiões próximas ao poço e tendem a um valor que corresponde ao da tensão inicial em posições mais remotas. De acordo com a Figura 3-5, Figura 3-6 e Figura 3-7, os valores das tensões radiais e tangenciais em regime elástico obtidos pelo programa Abaqus ${ }^{\circledR}$ e da solução de Kirsch são coincidentes, com pequenos erros percentuais em relação à essa solução. 


\subsubsection{Solução de Bradley}

A solução de Bradley é realizada levando em consideração o mesmo problema da abertura de um furo de raio $R$ em uma placa submetida a um estado de tensões. Bradley (1979) complementou a formulação de Kirsch (1898) levando em consideração uma pressão interna no furo. Para a simulação da perfuração de poços de petróleo no Abaqus ${ }^{\circledR}$, a presença do fluido no interior do furo se dá pela pressão gerada pelo peso do fluido de perfuração.

As equações de Bradley aplicadas em um ponto localizado na coordenada polar $r, \theta$, próximo ao furo de raio $R$ (Figura 3-4) tem tensões $\sigma_{r}$ e $\sigma_{\theta}$, levando em consideração a presença de um fluido com pressão $P_{w}$ no interior do furo, dadas por (FJAR et al., 2008):

$$
\sigma_{r}=\frac{\sigma_{1}+\sigma_{2}}{2}\left(1-\frac{R^{2}}{r^{2}}\right)+\frac{\sigma_{1}-\sigma_{2}}{2}\left(1-\frac{4 R^{2}}{r^{2}}+\frac{3 R^{4}}{r^{4}}\right) \cos 2 \theta+\tau_{12}\left(1-\frac{4 R^{2}}{r^{2}}+\frac{3 R^{4}}{r^{4}}\right) \sin 2 \theta+P_{w} \frac{R^{2}}{r^{2}}
$$

$$
\sigma_{\theta}=\frac{\sigma_{1}+\sigma_{2}}{2}\left(1+\frac{R^{2}}{r^{2}}\right)-\frac{\sigma_{1}-\sigma_{2}}{2}\left(1+\frac{3 R^{4}}{r^{4}}\right) \cos 2 \theta-\tau_{12}\left(1+\frac{3 R^{4}}{r^{4}}\right) \sin 2 \theta+P_{w} \frac{R^{2}}{r^{2}},
$$

sendo:

$\sigma_{r}$ é a tensão normal efetiva na direção radial;

$\sigma_{\theta}$ é a tensão normal efetiva na direção tangencial;

$\sigma_{1}$ é a tensão in situ na direção 1;

$\sigma_{2}$ é a tensão in situ na direção 2;

$R$ é o raio do poço;

$r$ é a distância a partir do eixo do poço;

$\theta$ é o ângulo medido no sentido anti-horário do plano 1-2 a partir do eixo 1; e

$P_{w}$ é a pressão provocada pelo peso do fluido de perfuração.

Para este exercício de validação, foi utilizado um peso de fluido de $9 \mathrm{ppg}$, o qual corresponde à pressão de $63,8 \mathrm{MPa}$ para a profundidade de estudo de $6000 \mathrm{~m}$.

A Figura 3-8 apresenta os resultados do Abaqus ${ }^{\circledR}$ versus os resultados das equações de Bradley (1979) para o modelo 1 (10xR). A Figura 3-9 e a Figura 3-10 mostram os resultados para os modelos $3(20 \mathrm{xR})$ e $6(35 \mathrm{xR})$, respectivamente. 


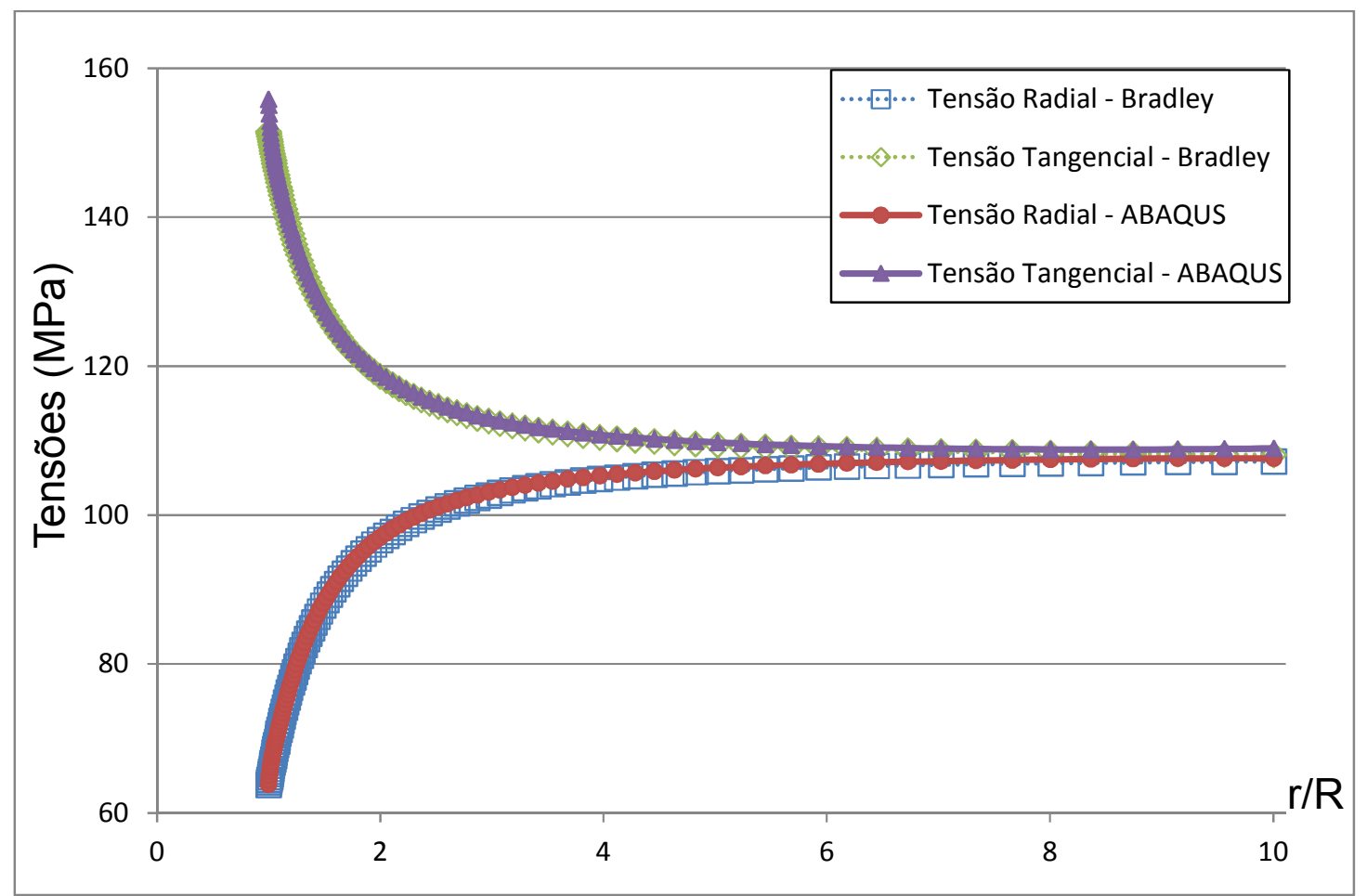

Figura 3-8 - Solução elástica: Bradley (1979) versus Abaqus ${ }^{\circledR}$ : tamanho de malha 10 x raio.

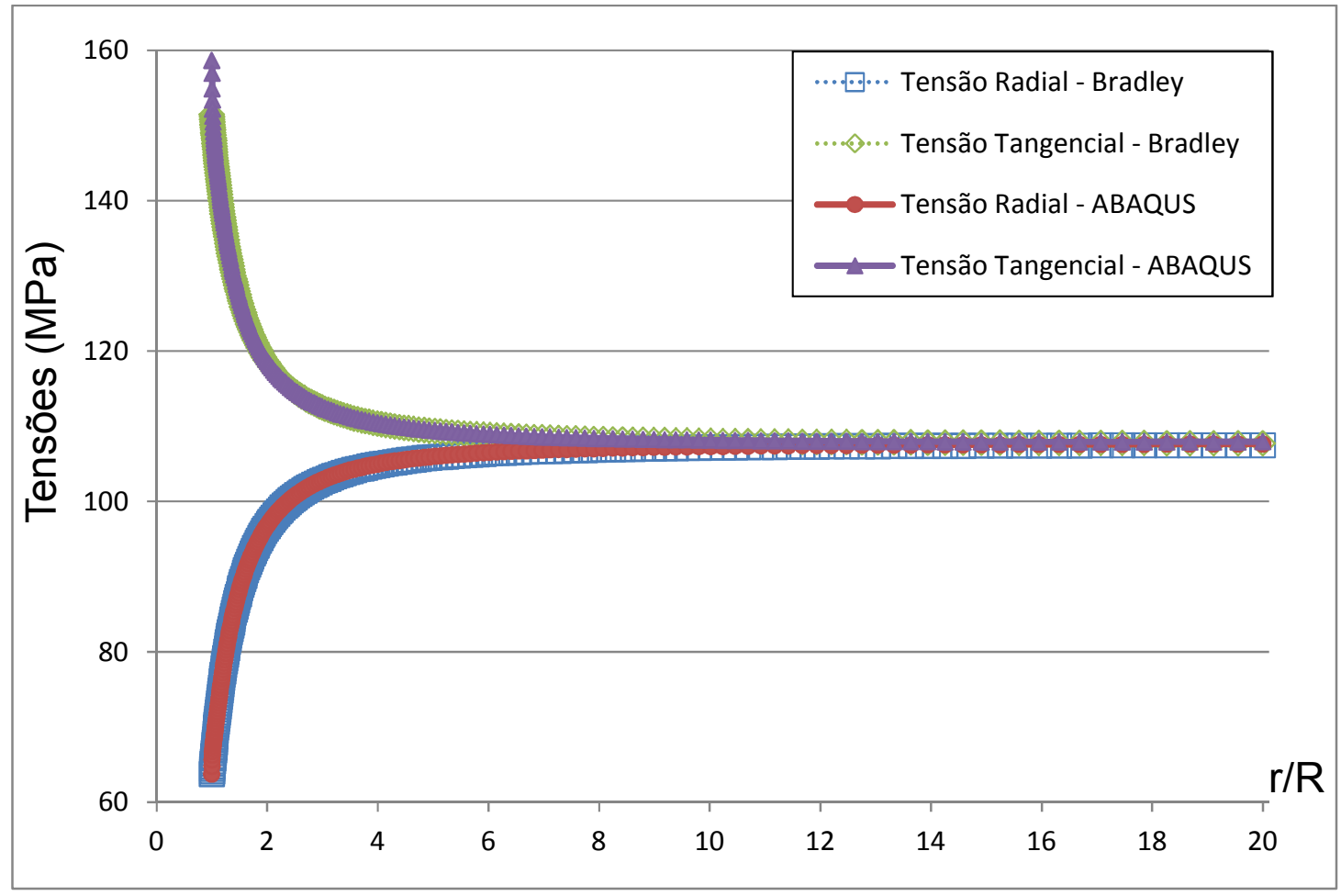

Figura 3-9 - Solução elástica: Bradley (1979) versus Abaqus ${ }^{\circledR}$ : tamanho de malha 20 x raio. 
A mesma observação feita para as simulações validadas por Kirsch, também se aplica a solução de Bradley, em que à medida que se tem um aumento da malha do modelo, o erro percentual entre às tensões analisadas pelo Abaqus e a solução analítica nas regiões mais remotas ao poço tende a ser menor. Para o modelo 1, Figura 3-8, esse erro é de 0,4\% para as tensões radiais e $0,8 \%$ para as tensões tangenciais. Para o modelo 3, Figura 3-9, as tensões ocasionadas pela perfuração se aproximam dos valores das tensões iniciais, com erro de $0,1 \%$ das tensões radiais e $0,2 \%$ das tensões tangenciais nas regiões mais distantes ao poço. Ao aumentar o valor da dimensão da malha, este valor se aproxima cada vez mais, atingindo um erro de $0,03 \%$ para as tensões radiais e $0,07 \%$ para as tensões tangenciais, ao analisar a dimensão de 35 vezes o raio do poço (Figura 3-10).

Percebe-se mais uma vez, que o uso do modelo de 20 vezes o raio do poço é adequado, visto que apresenta pequenos erros percentuais nas regiões mais remotas ao poço devido à escavação, com um custo computacional cabível.

Os valores para as tensões radiais e tangenciais obtidas da fase elástica do Abaqus ${ }^{\circledR}$, apresentam baixos erros percentuais em relação a formulação de Bradley. De modo geral, os resultados obtidos pelas equações de Kirsch e Bradley validam o uso do Abaqus ${ }^{\circledR}$ para o estudo da simulação numérica do problema proposto.

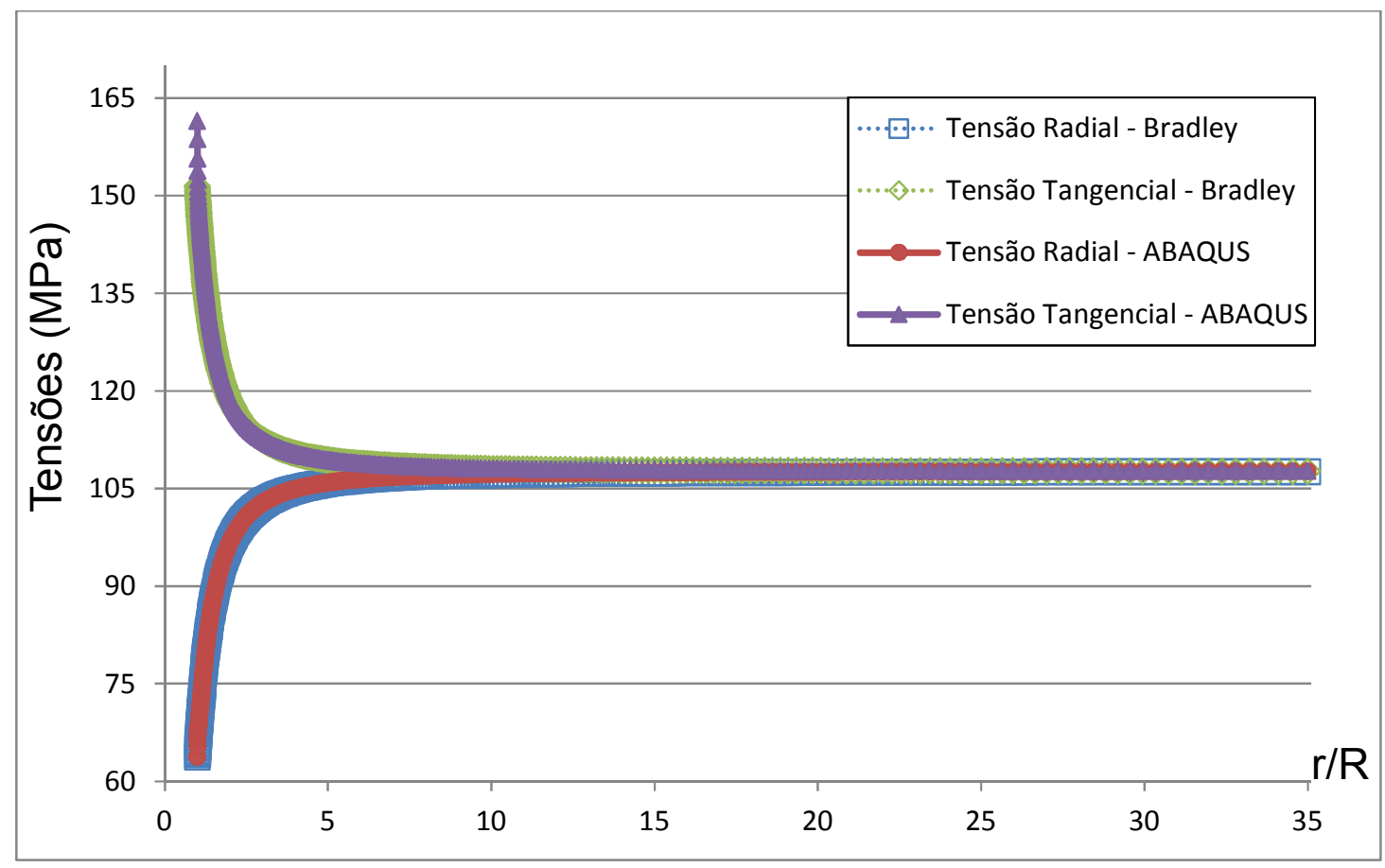

Figura 3-10 - Solução elástica: Bradley (1979) versus Abaqus ${ }^{\circledR}$ : tamanho de malha 35 x raio. 


\subsubsection{Resultados e discussões da simulação do poço de petróleo em evaporito}

O modelo plano de deformação analisado correspondeu a um plano de 3,10 m x 3,10 $\mathrm{m}$, localizado a uma profundidade de $6000 \mathrm{~m}$ abaixo do nível do mar, conforme mostrado na Figura 3-2a, com as condições de contorno apresentadas na Figura 3-3 e tensão de sobrecarga igual a 107,6 MPa. O modelo é composto por 6700 nós e 6622 elementos, dos quais 86 elementos foram do tipo CPE3, na região do poço a ser escavada, e 6536 elementos do tipo CPE4, no restante da malha. A Figura 3-11 apresenta a malha de elementos finitos para a simulação da perfuração do poço e na Figura 3-12 pode ser visto o zoom próximo a região a ser escavada, com o nó em destaque na parede do poço, representando o nó em que são tomados os dados para análise do modelo plano de deformação.

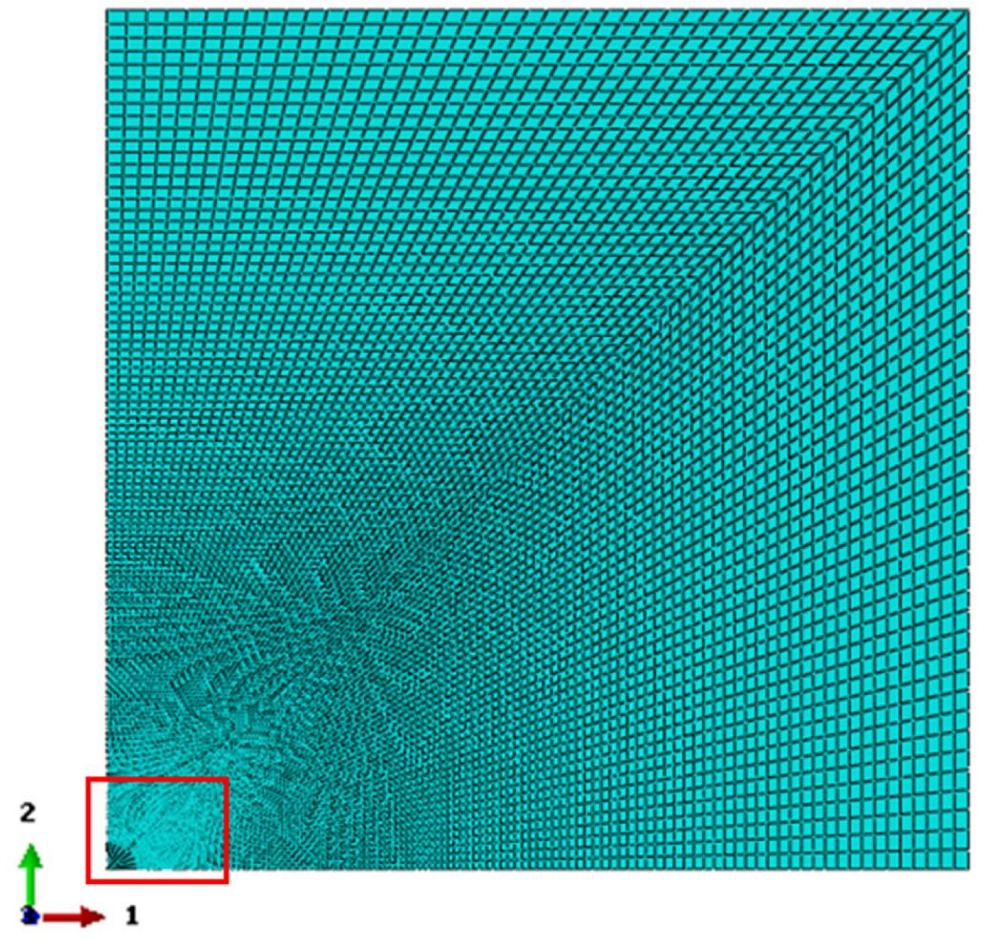

Figura 3-11 - Vista geral da malha de elementos finitos utilizada na simulação numérica da perfuração do poço. 


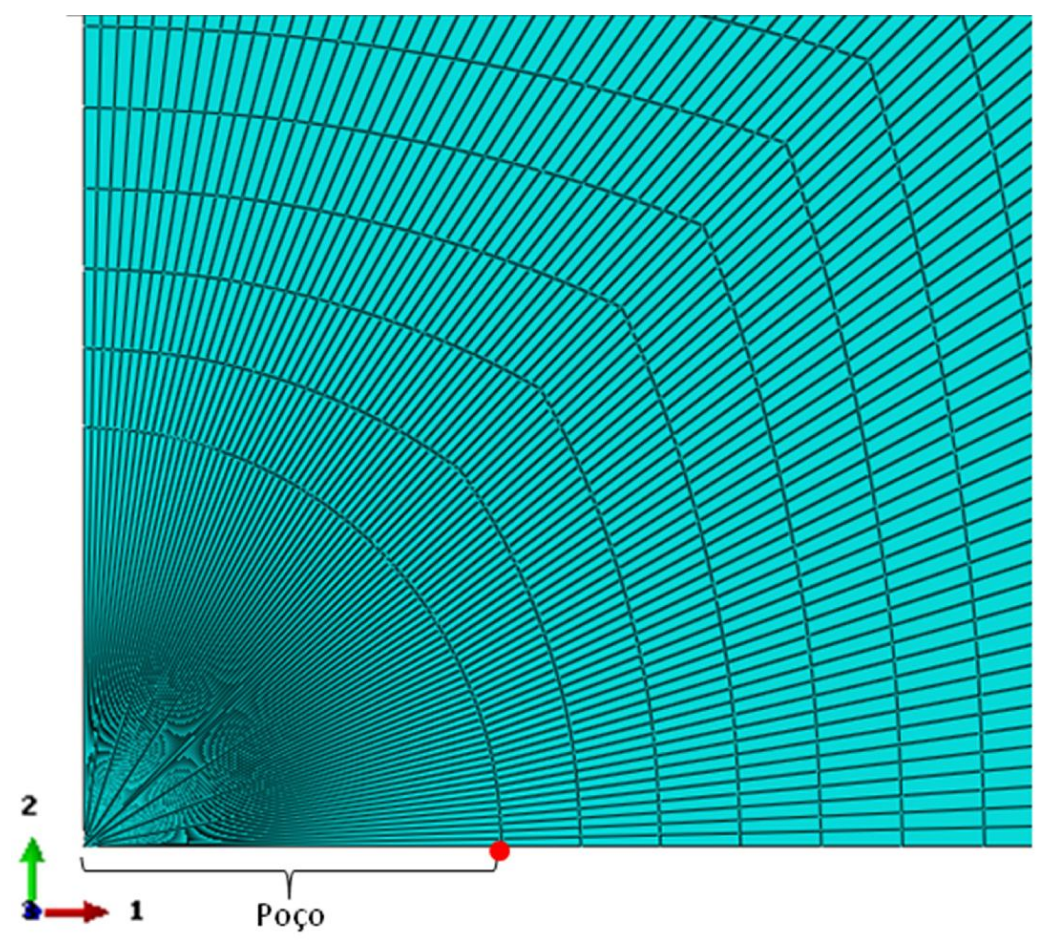

Figura 3-12 - Detalhe da região próxima ao poço em destaque na Figura 3-11, com a representação do nó de análise na parede do poço.

Foram realizadas análises de deslocamentos, deformações e tensões após a simulação da perfuração do poço de petróleo utilizando a solução elástica instantânea e a fluência de 30 dias, para os diversos pesos de fluidos de perfuração (Tabela 3-2).

Os resultados do modelo plano de deformação são condizentes com os apresentados por Botelho (2008).

\subsubsection{Deslocamentos}

As análises dos deslocamentos radiais foram realizadas considerando os dados do nó na parede do poço, como destacado na Figura 3-12, no sentido do eixo 1. As medições foram feitas para os diferentes pesos de fluido de perfuração em um período de 30 dias após a escavação, as quais estão representadas na Figura 3-13. O sinal negativo indica que o deslocamento acontece para a esquerda, no sentido contrário ao eixo 1, ou seja, está ocorrendo um fechamento do poço.

A Figura 3-13 mostra que à medida que se aplica um maior peso de fluido de perfuração, o fechamento do poço é menor. Este fato é evidenciado decorrente da menor 
diferença entre as tensões horizontais in situ e aquelas aplicadas à parede do poço devido ao peso do fluido de perfuração. Ao utilizar o peso do fluido de $13 \mathrm{ppg}$, tem-se um fechamento do poço correspondente a $10,6 \%$ do valor do fechamento quando aplicado o peso de fluido de 9 ppg.

Desta forma, percebe-se a importância da escolha do fluido de perfuração a ser aplicado durante a perfuração de poços de petróleo, de modo a adotar aquele que ocasione um menor fechamento e assim, menores problemas decorrentes desse fechamento.

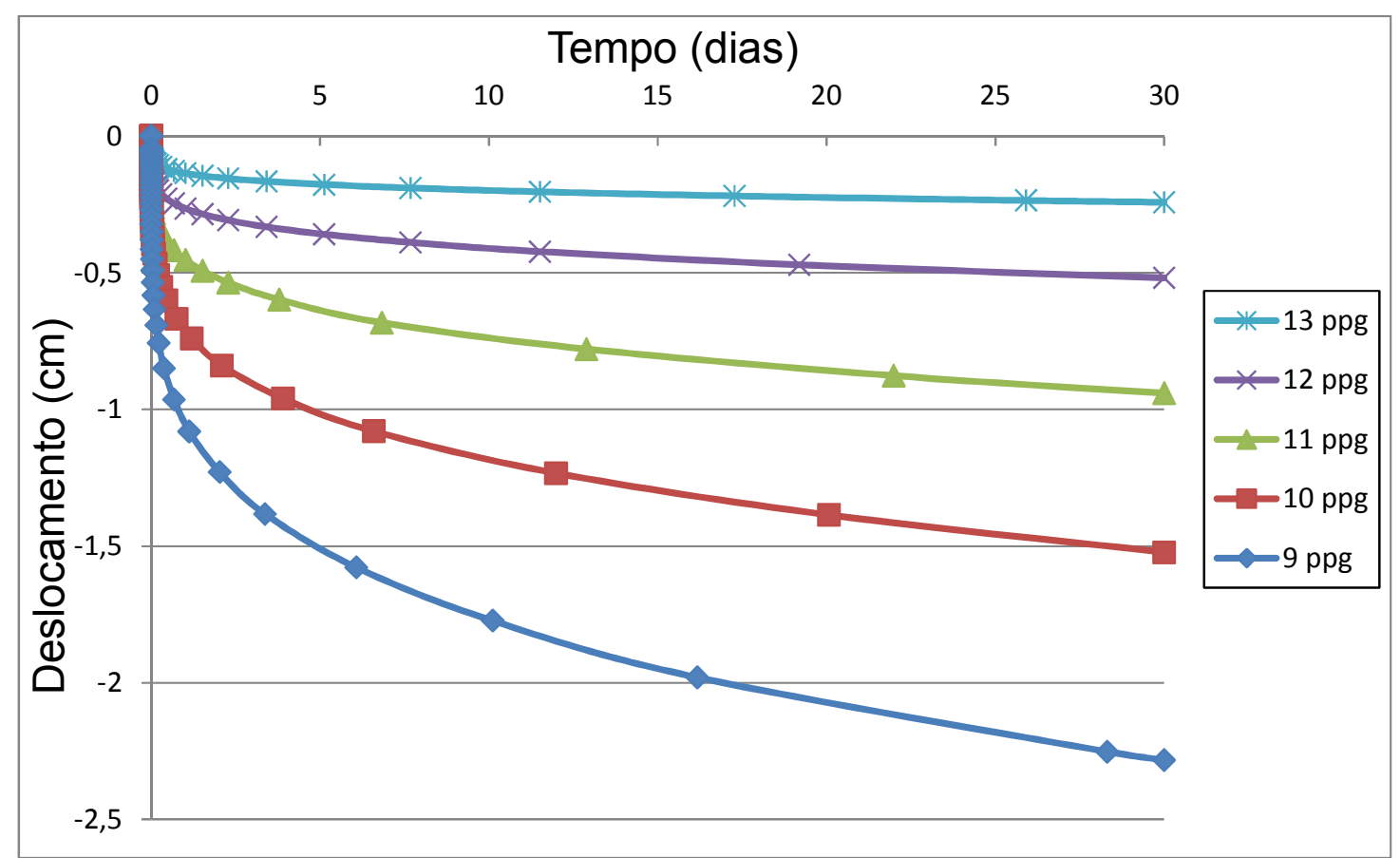

Figura 3-13 - Fechamento do poço para os diferentes pesos do fluido de perfuração em um período de 30 dias.

A Figura 3-14 apresenta as mesmas curvas da Figura 3-13, porém com a análise do desenvolvimento dos deslocamentos radiais no primeiro dia após a perfuração. Os deslocamentos mais significativos ocorrem no primeiro dia independentemente do peso do fluido aplicado. Como exemplos, tem-se que em 1 dia após a perfuração, o poço obteve $47,3 \%$ do fechamento total, no período de 30 dias, quando utilizado o menor peso do fluido de perfuração (9 ppg). Neste mesmo período, para o fluido de perfuração de maior peso (13 ppg), o fechamento do poço foi de $56,2 \%$ do fechamento total (30 dias). 


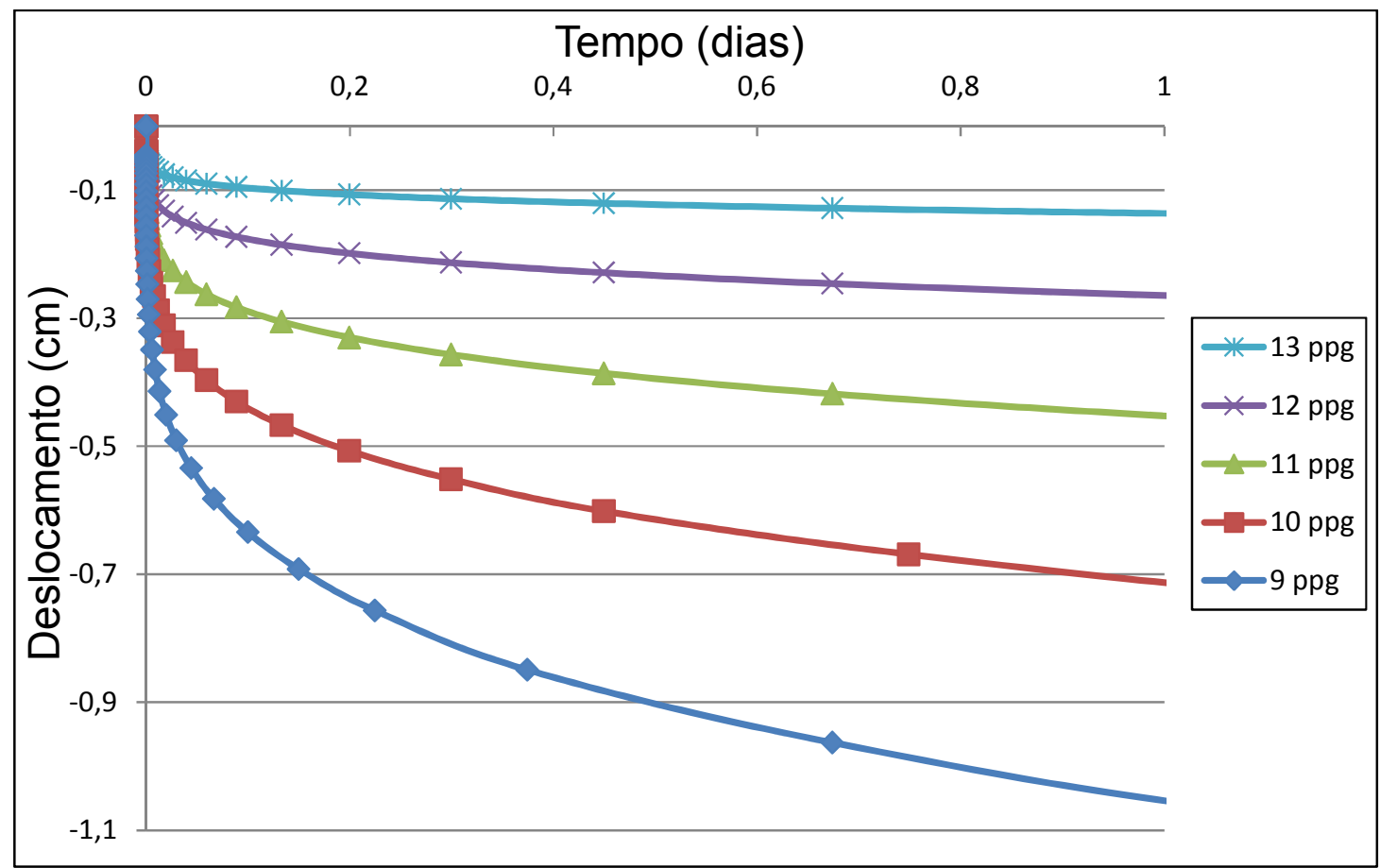

Figura 3-14 - Fechamento do poço para os diferentes pesos do fluido de perfuração em um período de 1 dia.

A Figura 3-15 representa os deslocamentos radiais do evaporito desde a parede do poço $(r / R=1)$ até uma distância equivalente a 20 vezes o raio do poço $(r / R=20)$, em que $R$ é o raio do poço e $r$ é o afastamento em relação ao eixo do poço, como já mostrado na Figura 34. Os deslocamentos horizontais foram calculados ao longo do eixo 1, para os diferentes pesos de fluido de perfuração.

Pode-se observar na Figura 3-15 que independentemente do peso de fluido de perfuração utilizado na simulação, os deslocamentos são maiores na parede do poço e decrescem à medida que se afastam dele. Para um período de análise de 30 dias, com o peso do fluido de perfuração de $13 \mathrm{ppg}$, o deslocamento na parede do poço foi de $0,24 \mathrm{~cm}$, enquanto que para um afastamento de cinco vezes o raio do poço $(r / R=5)$ esse deslocamento foi de $0,06 \mathrm{~cm}$ no sentido do fechamento do poço. Isso ocorre devido ao fato de que na parede do poço acontece uma maior perturbação nas tensões, que antes da escavação estavam constantes. Quanto mais afastado do poço, menores perturbações de tensões ocorrem, e consequentemente, menores deslocamentos por fluência. 


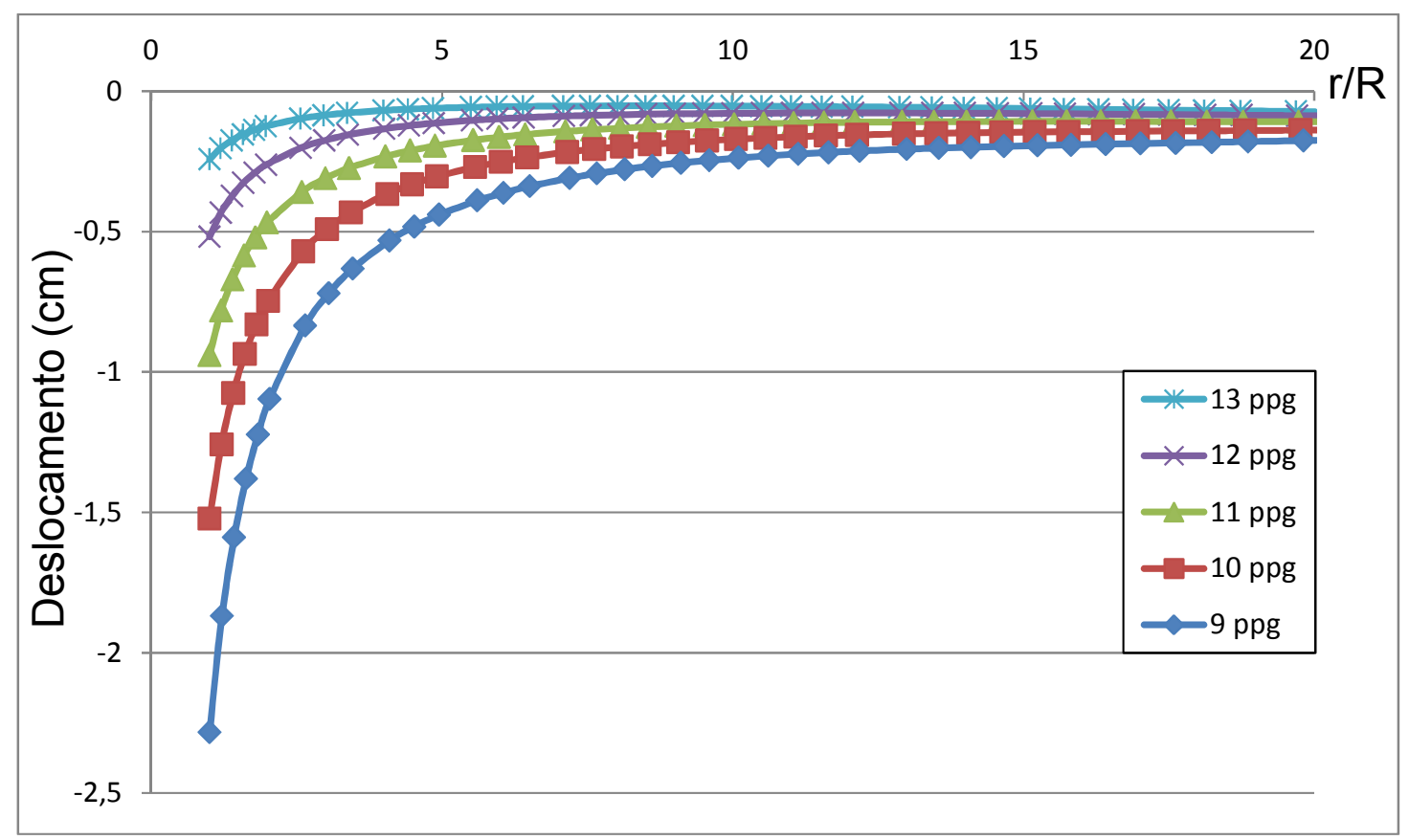

Figura 3-15 - Deslocamento radial ao redor do poço para os diferentes pesos do fluido de perfuração em um período de 30 dias.

No gráfico apresentado na Figura 3-16, pode-se analisar as curvas do fechamento do poço considerando apenas a solução elástica e, também, considerando a solução elástica e a fluência em um dia e em um mês, para diferentes pesos de fluidos de perfuração. Percebe-se claramente que os deslocamentos gerados apenas pela solução elástica do sal são pequenos quando comparados com os deslocamentos causados por fluência. Ainda, observa-se que nos primeiros instantes após a perfuração do poço, os deslocamentos são maiores que os demais.

Para um fluido com peso de 12 ppg, o deslocamento causado pela solução elástica e fluência de um dia foi de $0,26 \mathrm{~cm}$ e, considerando a fluência de um mês, esse deslocamento foi de $0,52 \mathrm{~cm}$. Ou seja, o fechamento do poço causado em um período de um dia de fluência corresponde a $51 \%$ do fechamento total dado em um período de um mês de fluência, enquanto que a solução elástica representa apenas $4,7 \%$ desse fechamento. Esse fato afirma a importância da consideração da fluência, principalmente nos primeiros instantes após a perfuração, quando se refere ao fechamento de poços perfurados em camadas salinas. 


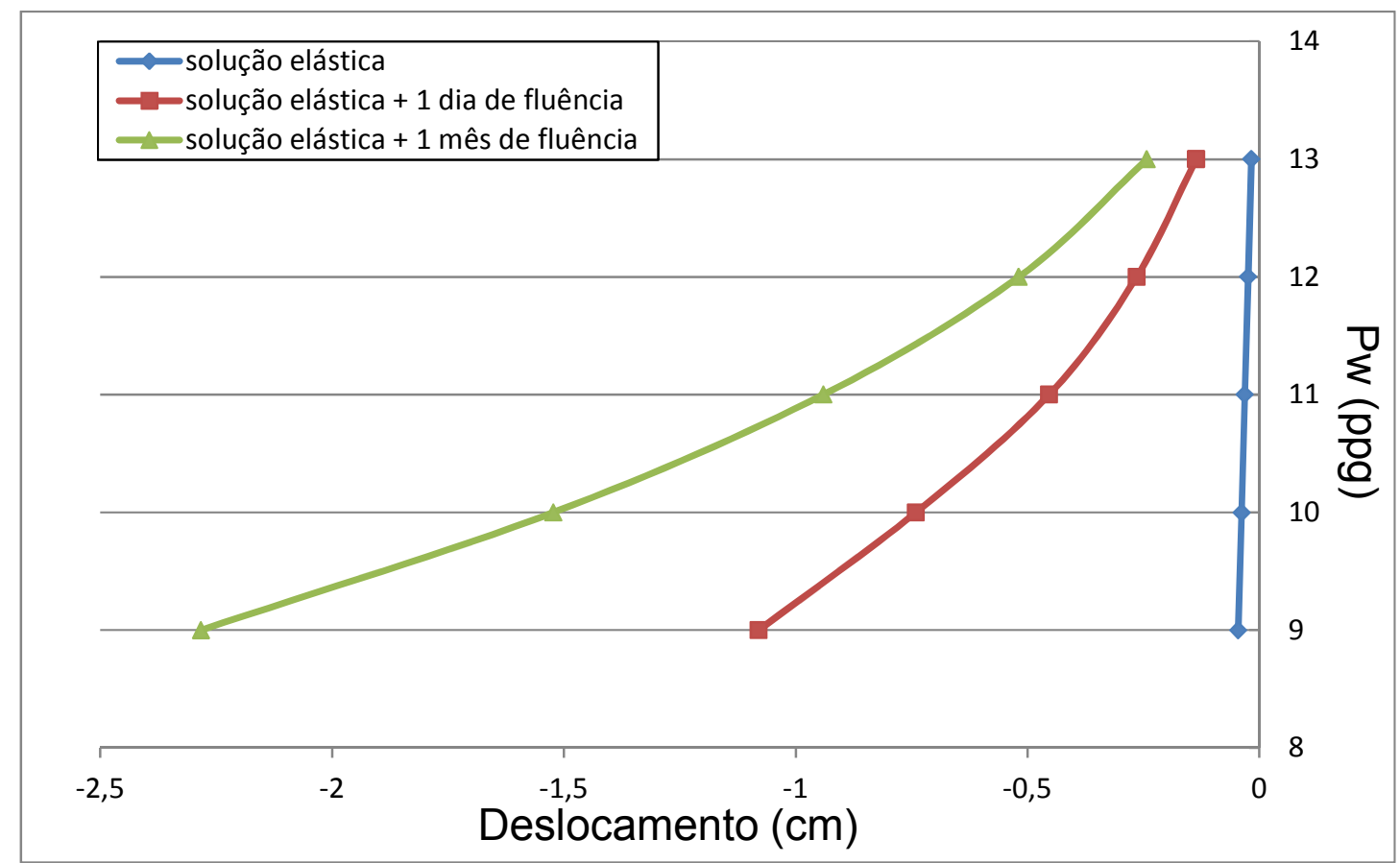

Figura 3-16 - Fechamento do poço para os diferentes pesos do fluido de perfuração considerando: solução elástica, solução elástica e fluência em 1 dia e em 30 dias.

A Figura 3-17 representa os deslocamentos no sentido do eixo 1, apresentada por uma escala de cores no Abaqus ${ }^{\circledR}$, para o modelo plano de deformação com peso do fluido de perfuração de 12 ppg, após um período de um mês de fluência. Essa forma de representação dos resultados permite a visualização da propagação dos efeitos geomecânicos da perfuração do sal. 

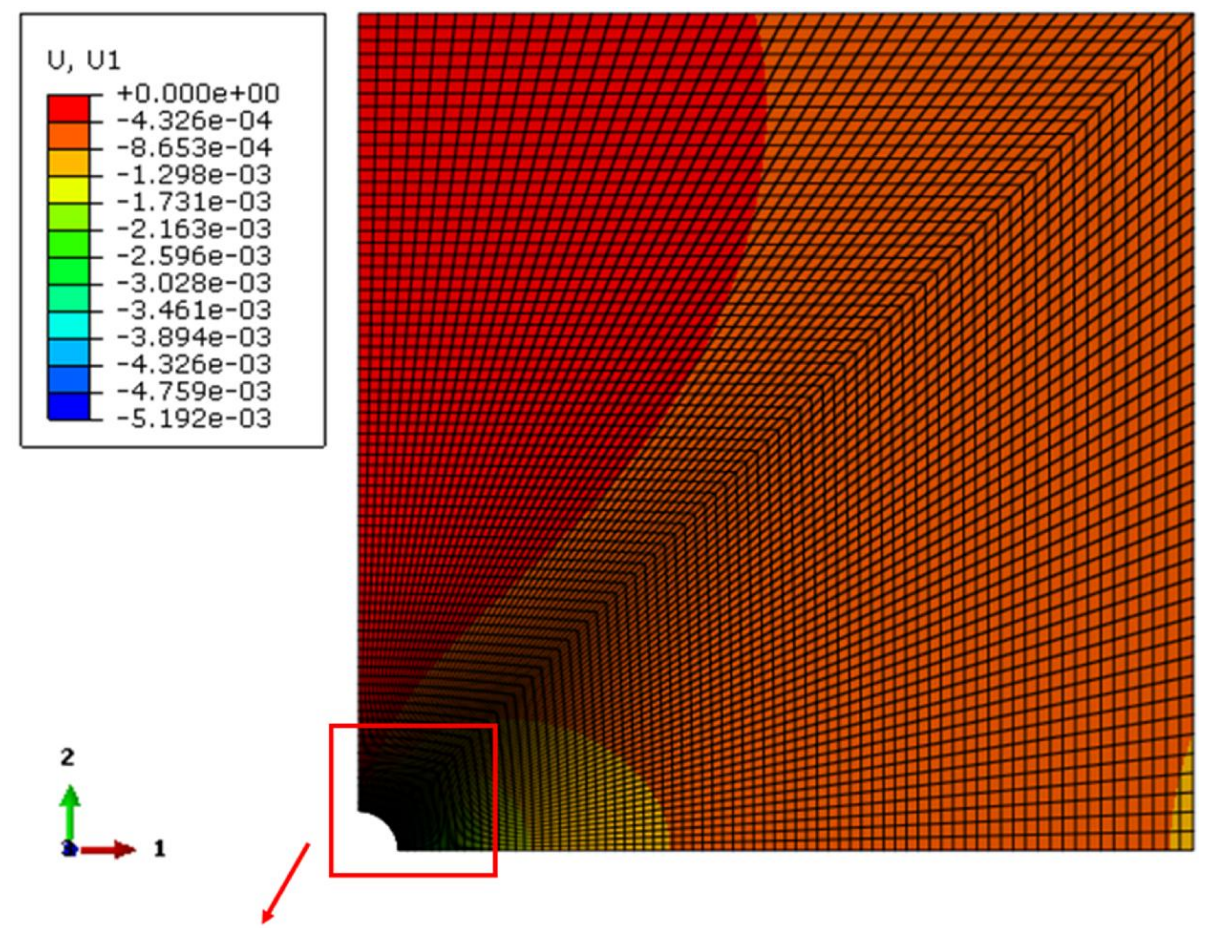

(a)

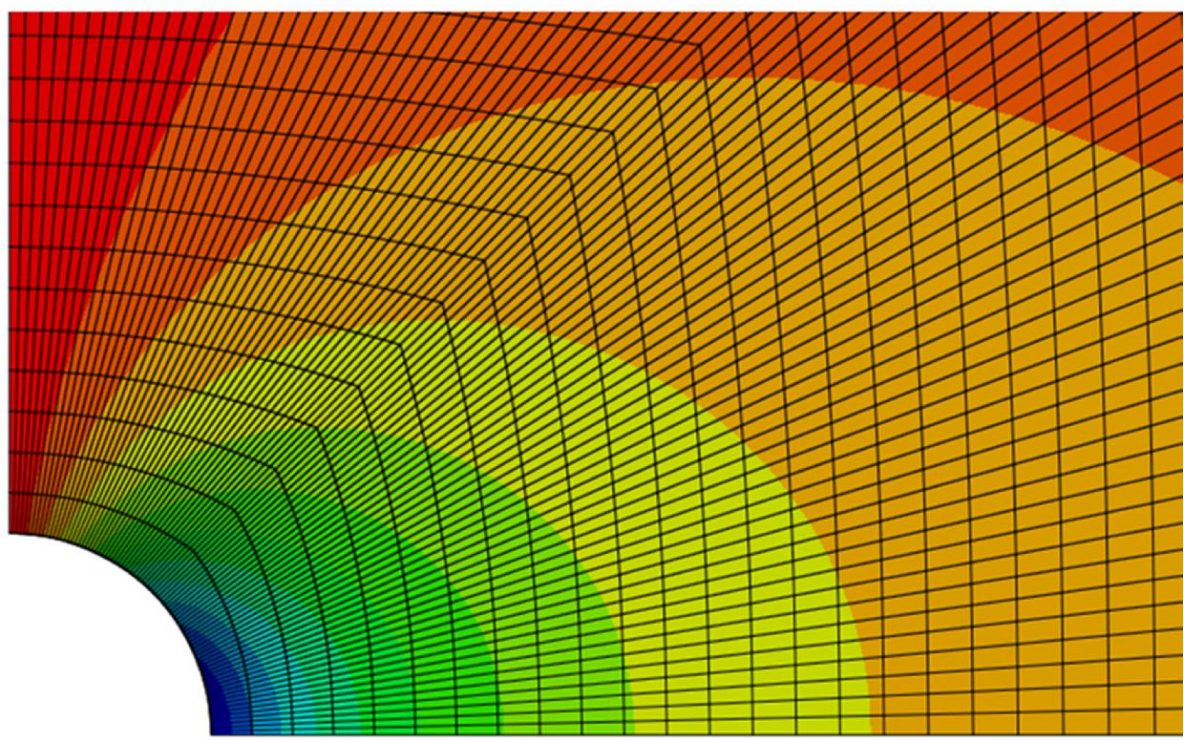

(b)

Figura 3-17 - Deslocamento em metros no sentido do eixo 1 após o período de um mês de fluência: (a) vista geral dos deslocamentos; (b) zoom na região ao redor do poço.

\subsubsection{Deformações}

As análises de deformações radiais na parede do poço foram realizadas considerando a utilização de diferentes pesos de fluido de perfuração para um período de fluência de 30 dias 
(Figura 3-18). Ainda foi observado a evolução das deformações para um período de um dia de fluência, como mostrado na Figura 3-19. Os cálculos de deformações foram feitos em um nó na parede do poço, em destaque na Figura 3-12, no sentido do eixo 1. Os valores de deformação em porcentagem são obtidos multiplicando os resultados apresentados pelo Abaqus ${ }^{\circledR}$ por 100 .

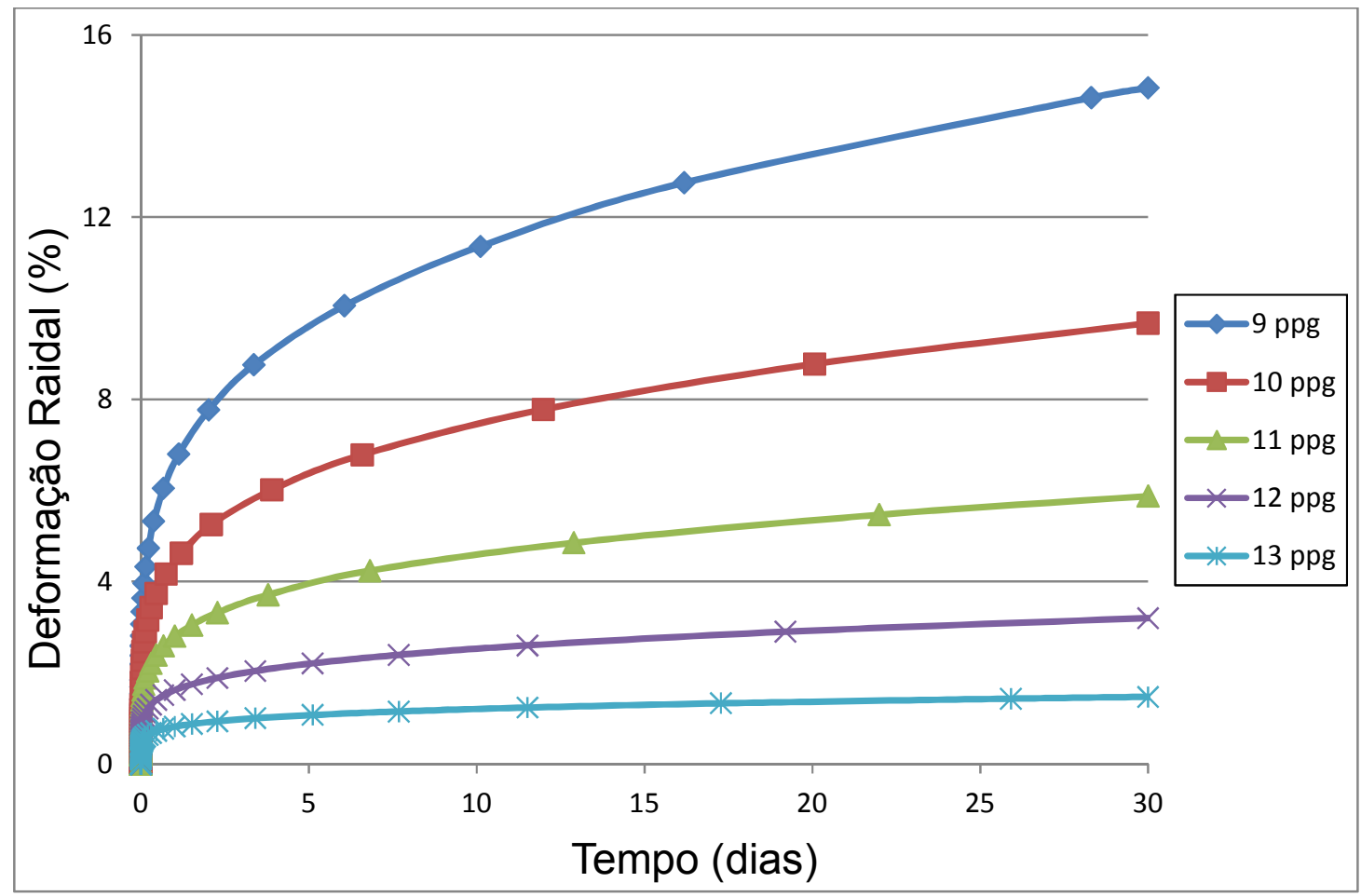

Figura 3-18 - Deformações radiais na parede do poço em um período de 30 dias, para os diferentes pesos do fluido de perfuração.

As simulações com pesos de fluido de perfuração menores apresentam maiores deformações radiais, tanto para pequenos intervalos como para um período de um mês. A utilização do menor peso do fluido de perfuração, causa maiores deformações devido a maior diferença de pressões geradas pelo peso do fluido e pelas tensões in situ. Em um período de 30 dias a deformação para um fluido com peso igual a 10 ppg é de $9,7 \%$, enquanto que para um fluido de 13 ppg, essa deformação é de $1,5 \%$.

A Figura 3-19 demonstra que a fluência é mais acentuada no primeiro dia após a perfuração do poço. Como exemplos, tem-se que em um dia após a perfuração, para um fluido de 9 ppg, a deformação foi de 6,8\%, enquanto que em 30 dias essa deformação foi de 14,8\%. Utilizando um fluido de perfuração de maior peso, com 13 ppg, a deformação em um dia correspondeu a 55,7\% da deformação total em um período de 30 dias. 


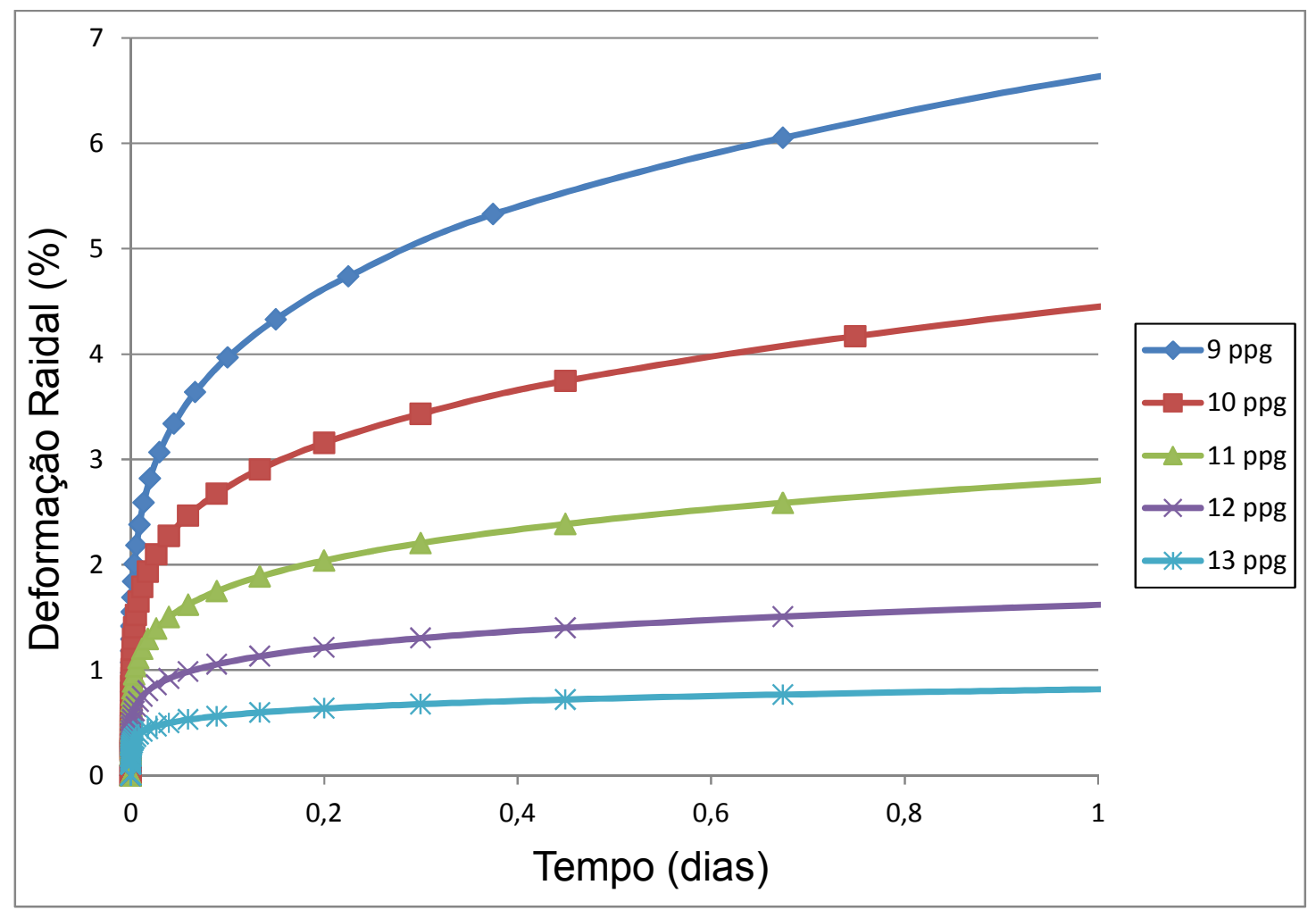

Figura 3-19 - Deformações radiais na parede do poço em um período de 1 dia, para os diferentes pesos do fluido de perfuração.

No gráfico apresentado na Figura 3-20, analisa-se as deformações considerando apenas a solução elástica e, também, considerando a solução elástica e a fluência em um dia e em um mês. Foram utilizados os diversos pesos de fluido de perfuração. Percebe-se que as deformações elásticas instantâneas são desprezíveis quando comparadas com as deformações causadas pela fluência do sal. Ainda, observa-se que nos primeiros instantes após a perfuração do poço, as deformações são maiores que os demais. Para um fluido com peso de 12 ppg, a deformação causada pela solução elástica e fluência de um dia foi de 1,6\%, e considerando a fluência de um mês, essa deformação foi de 3,2\%. Desta forma, a deformação causada em um período de um dia de fluência corresponde a $50,7 \%$ da deformação total em um período de um mês de fluência, enquanto que a solução elástica representa apenas 4,5\% dessa deformação.

Essas deformações por fluência dependem intrinsecamente da lei de fluência e dos parâmetros adotados na modelagem numérica. Uma vez alterado estes parâmetros, ocasiona diferentes deformações das apresentadas na Figura 3-20. 


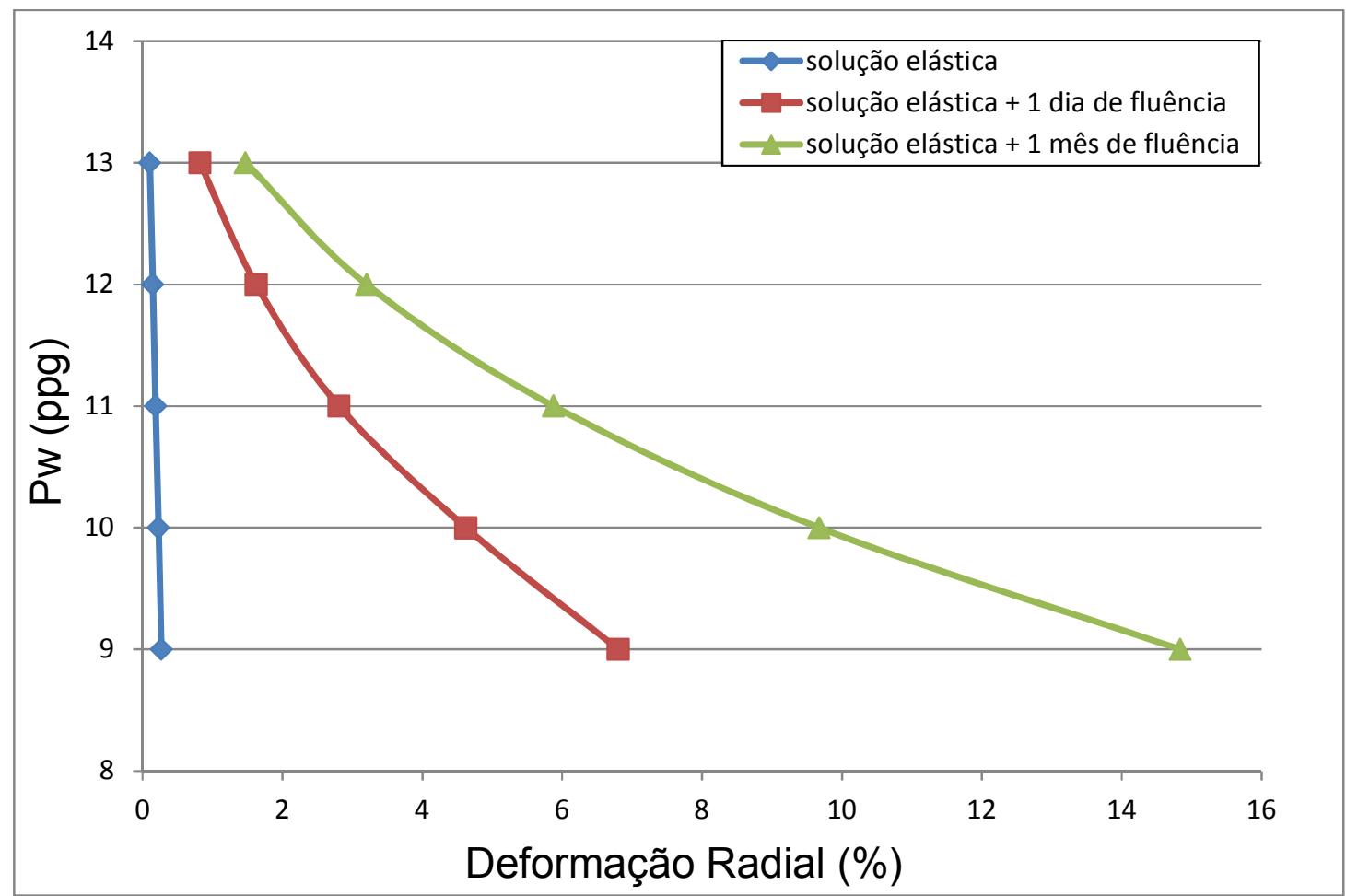

Figura 3-20 - Deformação radial para os diferentes pesos do fluido de perfuração considerando: solução elástica, solução elástica e fluência em 1 dia e em 30 dias.

A Figura 3-21 representa as deformações no sentido do eixo 1, apresentada por uma escala de cores no Abaqus ${ }^{\circledR}$, para o modelo plano de deformação com peso do fluido de perfuração de 12 ppg, após um período de um mês de fluência. 

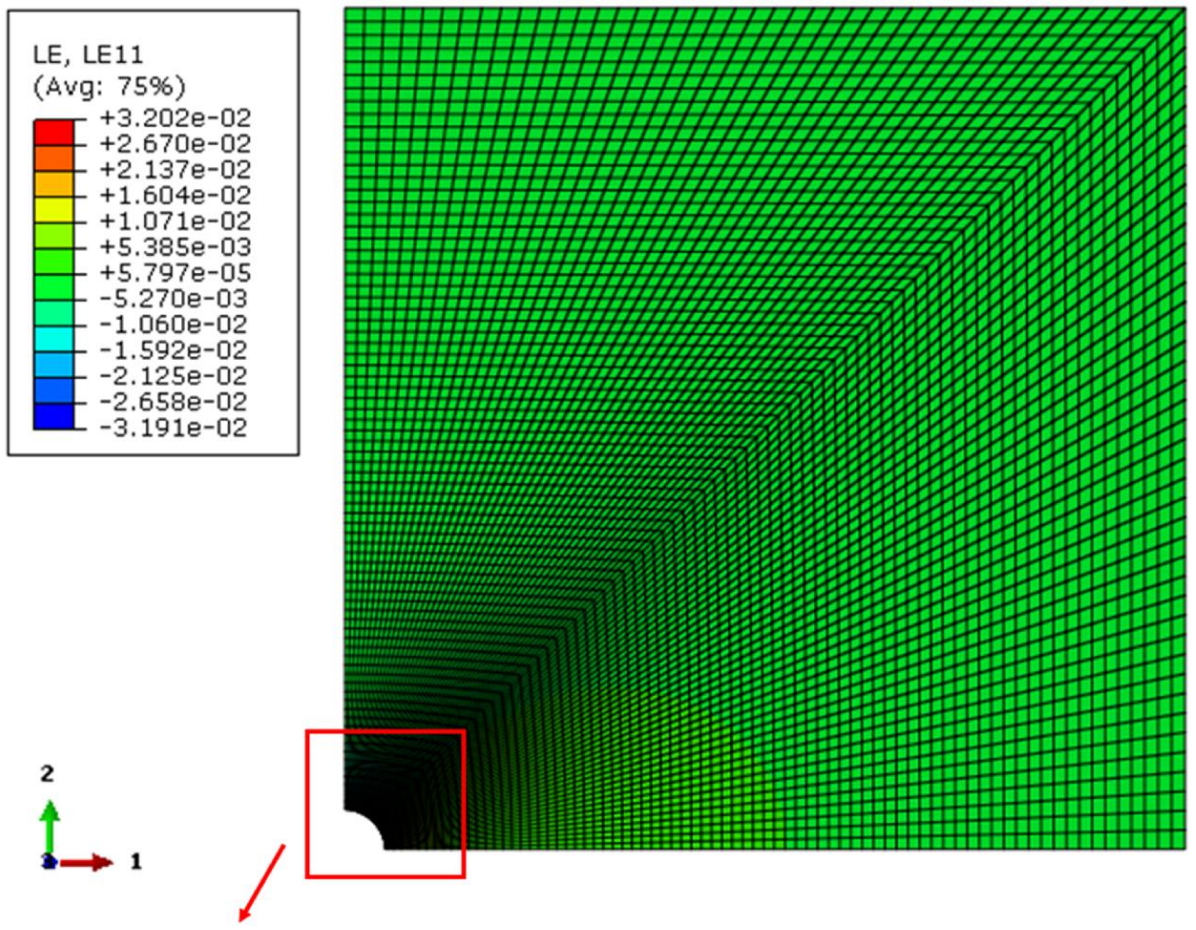

(a)

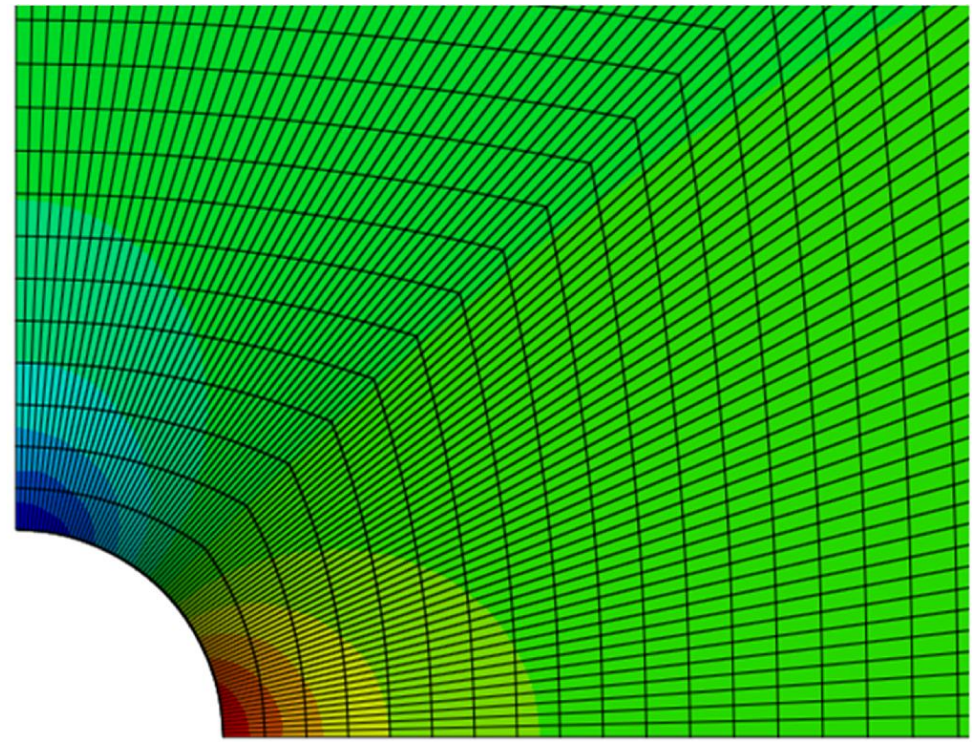

(b)

Figura 3-21 - Deformações no sentido do eixo 1 após o período de um mês de fluência: (a) vista geral das deformações; (b) zoom na região ao redor do poço. Para obter os valores em porcentagem, devese multiplicar os resultados apresentados pelo Abaqus ${ }^{\circledR}$ por 100 . 


\subsubsection{Tensões}

As tensões radiais e tangenciais ao longo do eixo 1 são medidas desde a parede do poço $(r / R=1)$ até 20 vezes o raio do poço $(r / R=20)$. A Figura 3-22 representa as distribuições de tensões radiais e tangenciais geradas pela solução elástica instantânea para os diferentes pesos de fluidos de perfuração. Percebe-se que independentemente do peso do fluido utilizado, as tensões radiais e tangenciais se igualam às tensões in situ (107,6 MPa) nas regiões mais remotas ao poço, como já visto na solução de Bradley (Item 3.3.1.2). O Abaqus ${ }^{\circledR}$ utiliza a convenção de que o valor negativo das tensões indica que está havendo esforço de compressão.

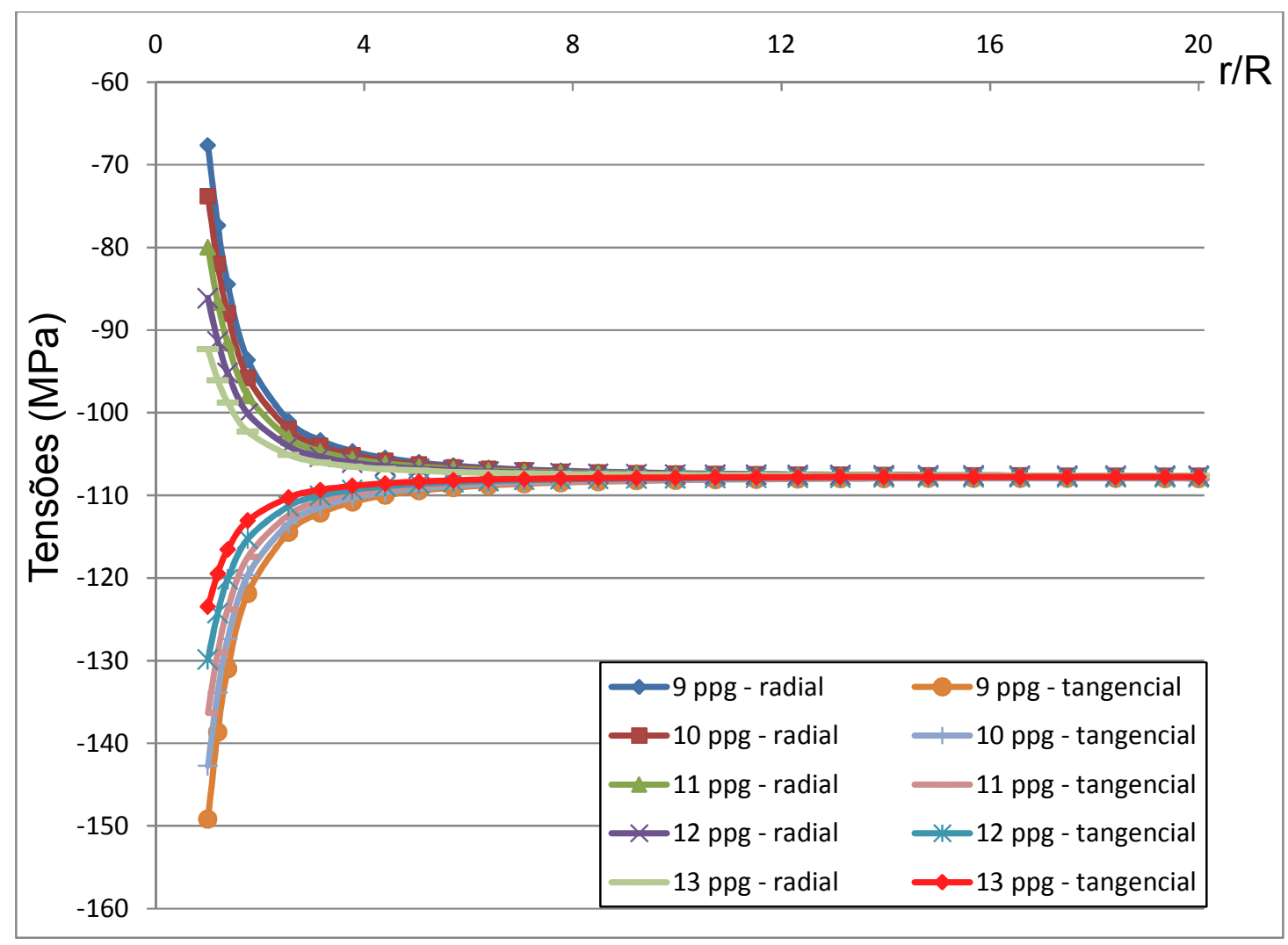

Figura 3-22 - Tensões ao redor do poço considerando apenas a solução elástica, para os diferentes pesos do fluido de perfuração.

A Figura 3-23 e Figura 3-24 apresentam as tensões radiais e tangenciais considerando a fluência em um dia e em um mês, respectivamente. Ao analisar estes gráficos, pode-se constatar que as tensões radiais igualam-se às tensões in situ nas regiões mais remotas ao poço, para qualquer peso do fluido utilizado. A distância da parede do poço para que estas 
tensões se igualem é maior no caso em que se analisa a fluência, do que ao analisar apenas a solução elástica (Figura 3-22).

As tensões radiais na parede do poço deveriam ser iguais às pressões provocadas pelos fluidos de perfuração. No entanto, pequenas diferenças são encontradas, já que os valores são calculados nos pontos de integração de cada elemento e, por meio da interpolação linear são obtidas as tensões nos nós dos elementos.

Observa-se também que a diferença entre as tensões próximas ao poço, tensões radiais e tangenciais, e a tensão inicial antes da perfuração é maior, quanto menor o peso do fluido de perfuração, o que ocasionará uma maior fluência devido à maior relaxação das tensões.

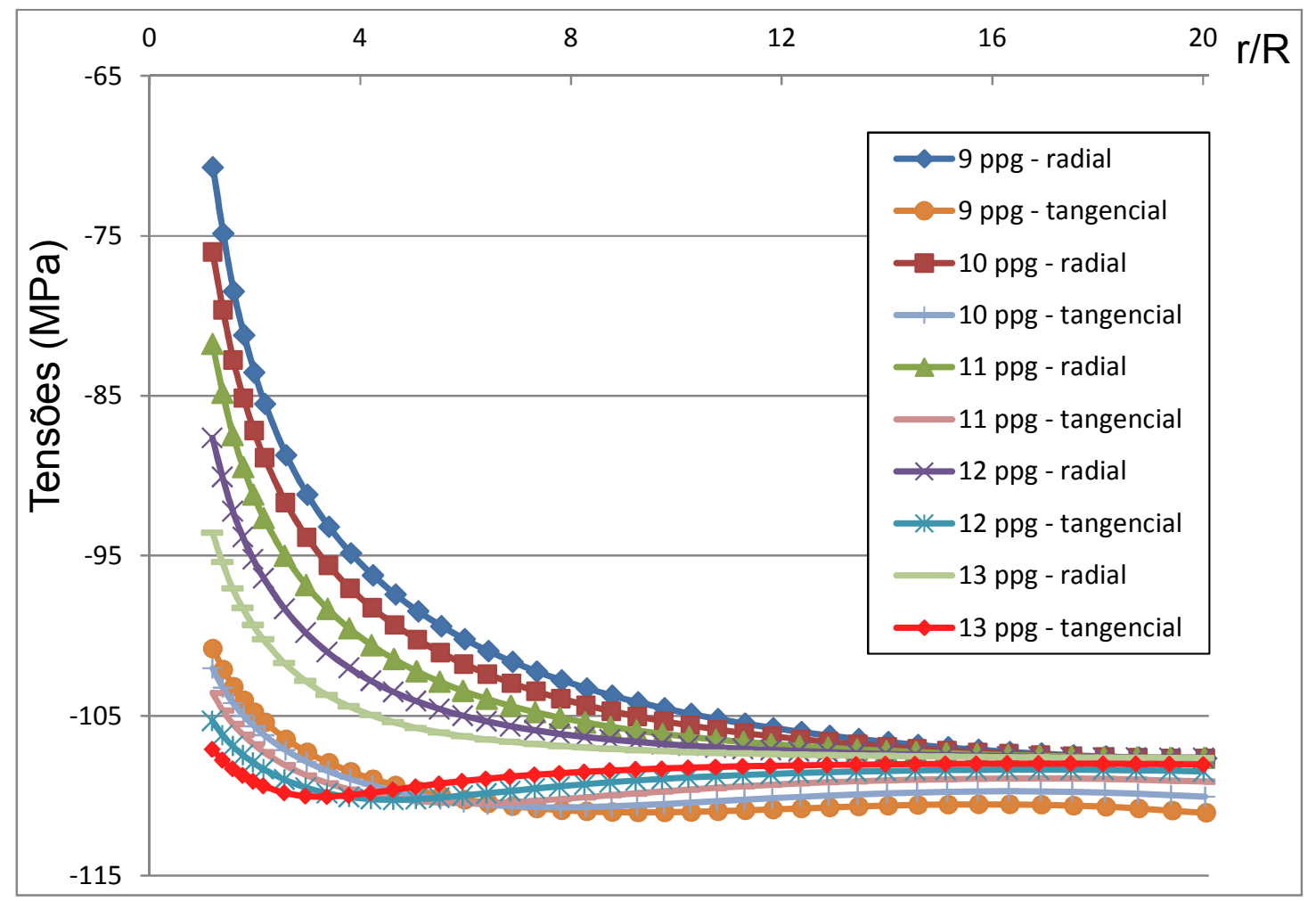

Figura 3-23 - Tensões ao redor do poço em um período de 1 dia de fluência, para os diferentes pesos do fluido de perfuração. 


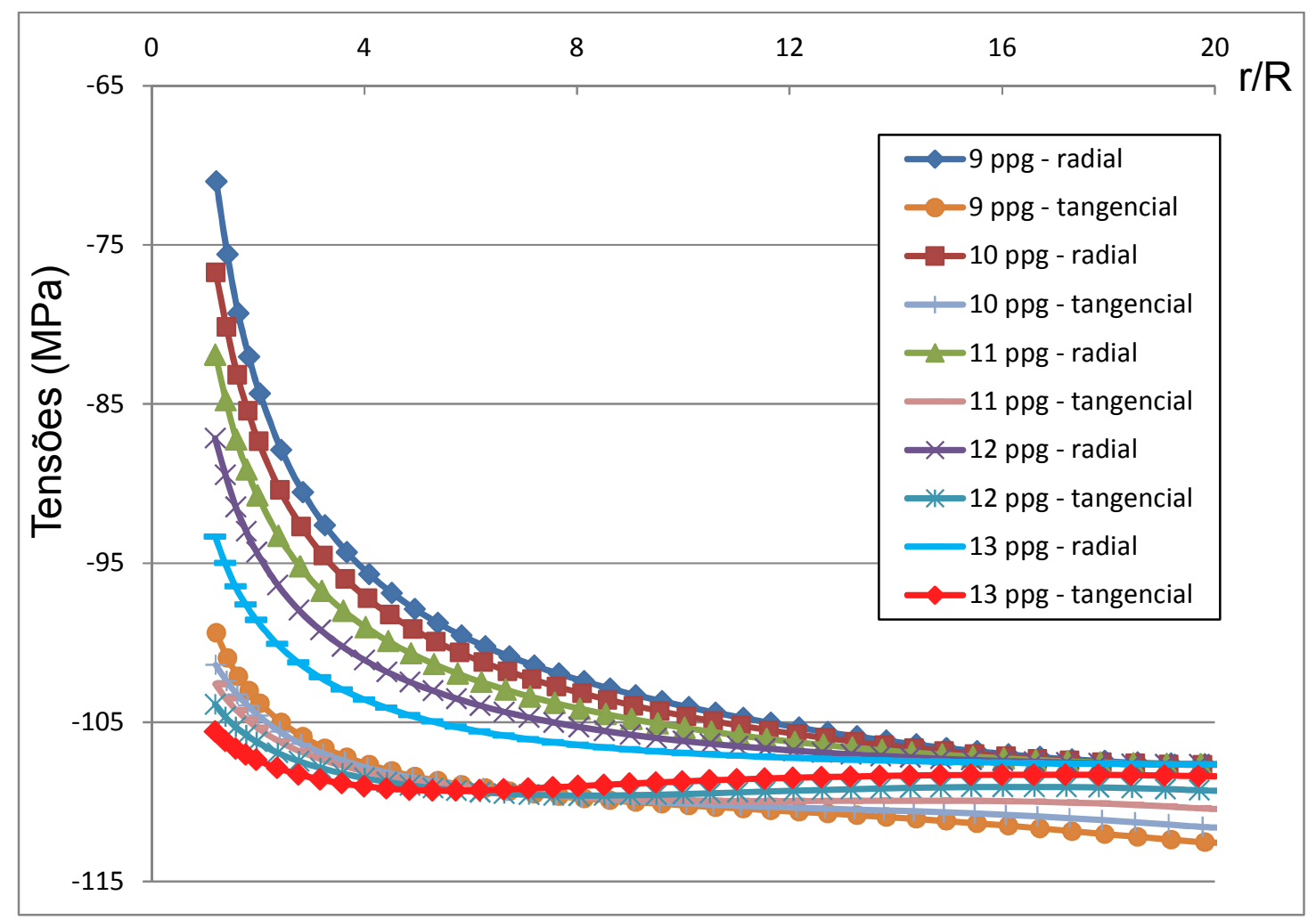

Figura 3-24 - Tensões ao redor do poço em um período de 30 dias de fluência, para os diferentes pesos do fluido de perfuração.

A Figura 3-25 representa as tensões no sentido do eixo 1, apresentada por uma escala de cores no Abaqus ${ }^{\circledR}$, para o modelo plano de deformação com peso do fluido de perfuração de 12 ppg, após a etapa geostática. A Figura 3-26 apresenta as tensões radiais após um período de um mês de fluência. Na Figura 3-27 tem-se o zoom da região em destaque na Figura 3-26, apresentando as tensões nas regiões próximas ao poço. 

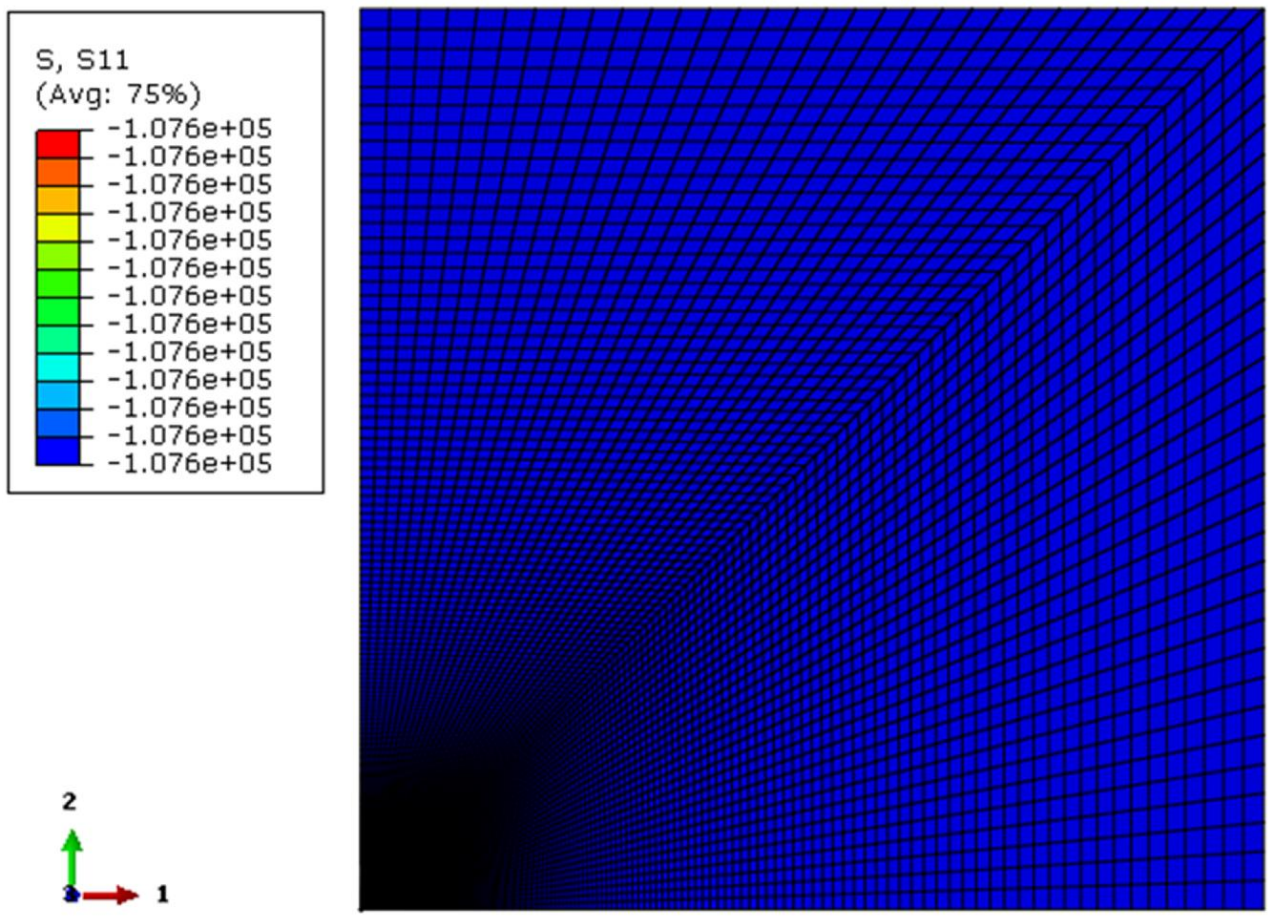

Figura 3-25 - Tensões radiais ao redor do poço em kPa após a etapa geostática.
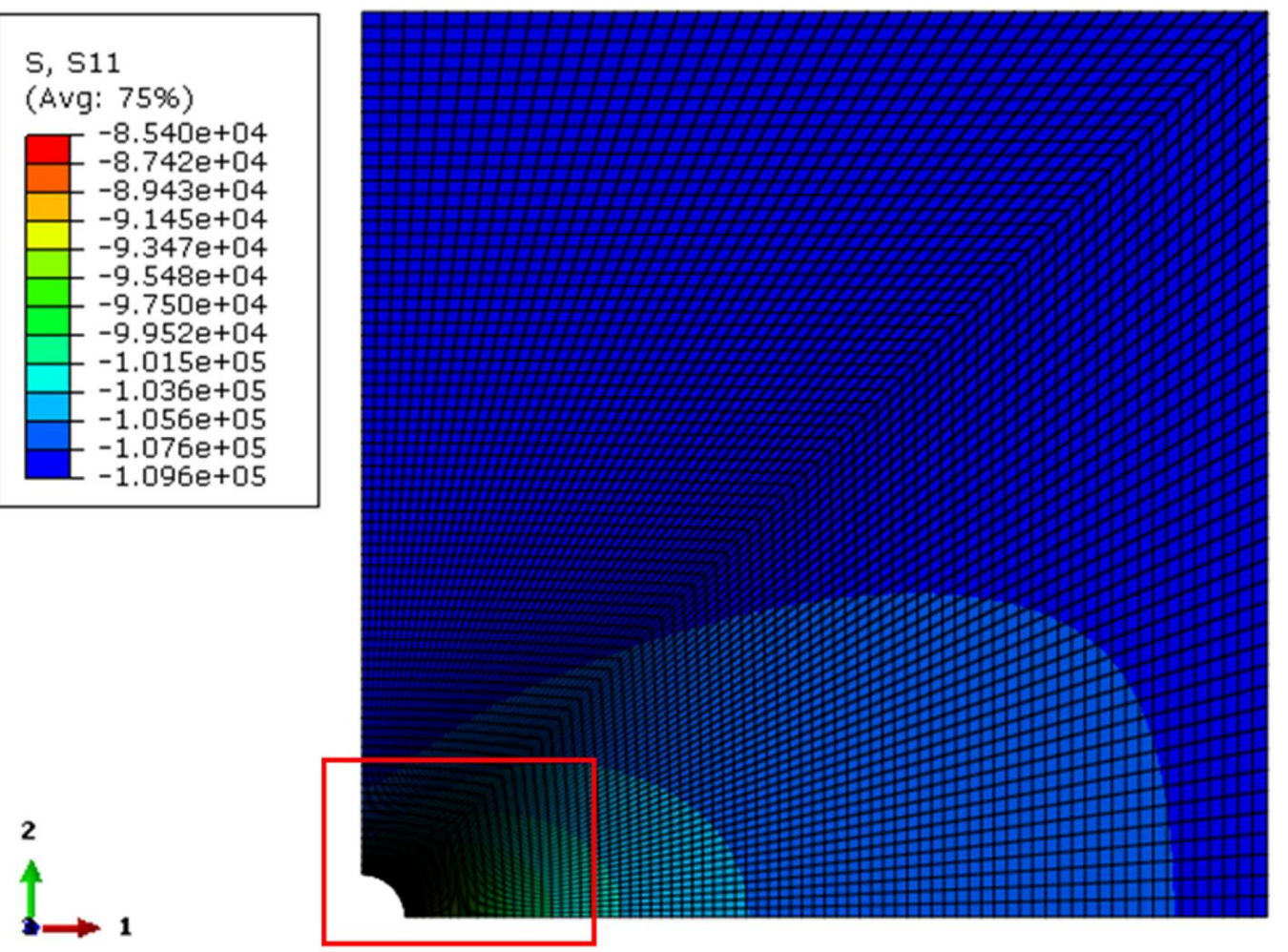

Figura 3-26 - Tensões radiais ao redor do poço em kPa após um período de um mês de fluência. 


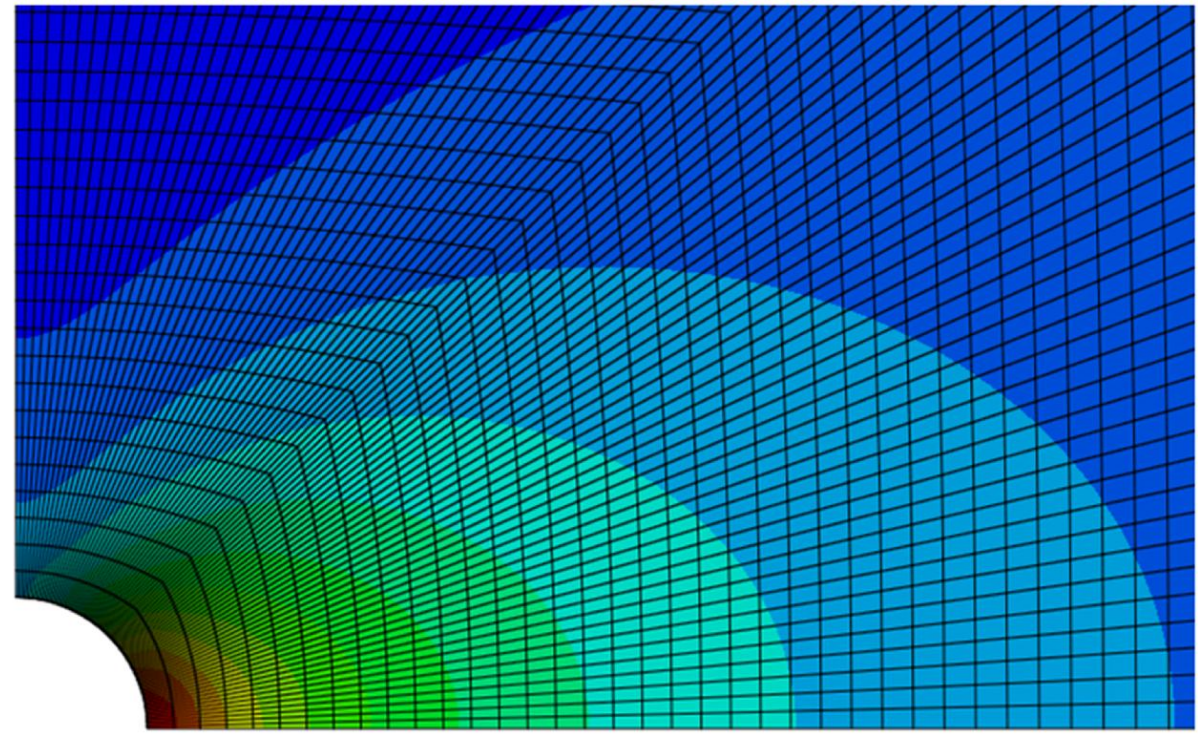

Figura 3-27 - Detalhe da região próxima ao poço em destaque na Figura 3-26, com a representação das tensões radiais em $\mathrm{kPa}$, após um período de um mês de fluência.

\subsection{MODELO AXISSIMÉTRICO DO POÇO}

A profundidade de estudo para o modelo axissimétrico do poço se estendeu de $6000 \mathrm{~m}$ a $6020 \mathrm{~m}$ abaixo do nível do mar, analisando o comportamento do evaporito ao longo de uma espessura de 20 metros, como mostrado na Figura 3-2b. Construiu-se uma malha de elementos finitos de $15 \mathrm{~m}$ x $20 \mathrm{~m}$, com diâmetro do poço de $0,31 \mathrm{~m}$, como representado na Figura 3-28.

As condições de contorno do modelo também estão representadas na Figura 3-28, em que estão presentes apoios do primeiro gênero na parte inferior da malha, de modo a impedir os deslocamentos na vertical e, na lateral direita, impedindo os deslocamentos na horizontal. O apoio do primeiro gênero no eixo de revolução do modelo, impedindo os deslocamentos na horizontal, é utilizado para garantir a condição de simetria no eixo do poço. 


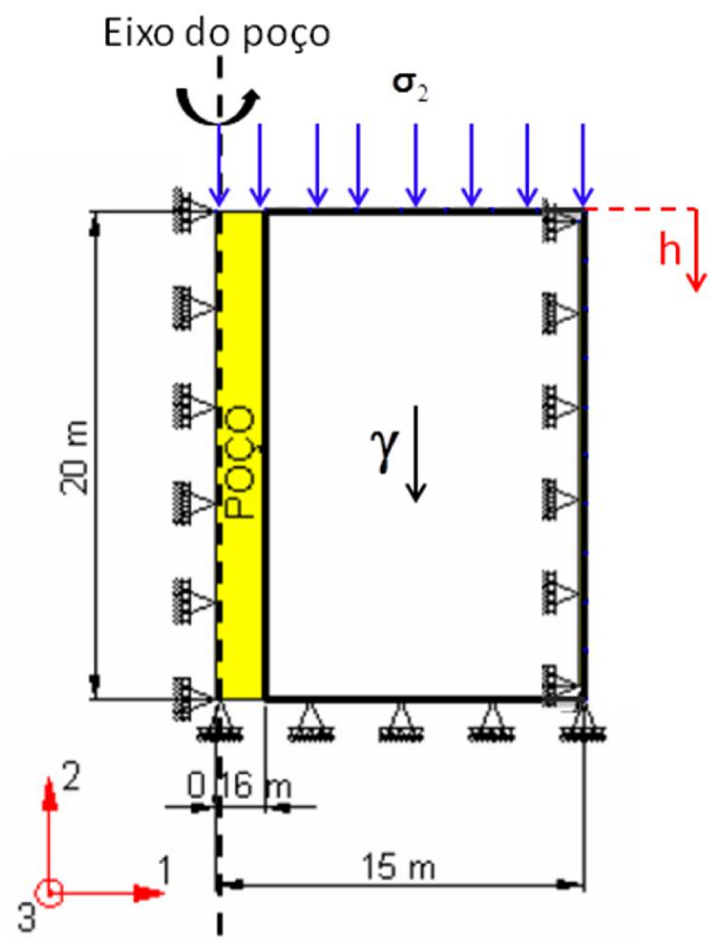

Figura 3-28 - Representação das condições de contorno, sem escala. Fonte: Modificada de Botelho (2008).

As tensões de sobrecarga foram anteriormente calculadas para uma profundidade de $6000 \mathrm{~m}$ abaixo do nível do mar, correspondendo a 107,6 $\mathrm{MPa}\left(\sigma_{2}\right)$. Essa tensão sofre variação com a profundidade no modelo utilizado. Ou seja, as tensões verticais tendem a aumentar, o que leva a um aumento das tensões horizontais. Para isso, o peso específico do material $(\gamma)$ foi definido no modelo (Figura 3-28), com a aceleração da gravidade igual a $9,81 \mathrm{~m} / \mathrm{s}^{2}$ e a massa específica do evaporito de $2160 \mathrm{~kg} / \mathrm{m}^{3}$. As tensões verticais ao longo da seção a ser perfurada podem ser obtidas a partir da Equação 3-14 em MPa:

$$
\sigma_{v}=\sigma_{2}=107,6+\gamma h
$$

onde, $0 \leq \mathrm{h} \leq 20$ corresponde à profundidade de interesse. Sendo $K_{0}=1$, as tensões verticais e horizontais são iguais para uma determinada profundidade $\left(\sigma_{1}=\sigma_{2}\right)$.

Nesta modelagem, foram realizados 10 estágios de escavações de 2 metros cada, no total de 20 metros, visando à simulação do andamento da perfuração do poço, conforme mostrado na Figura 3-29. Para toda a malha foram utilizados elementos quadrilaterais bilineares de 4 nós, denominados de CAX4 no Abaqus ${ }^{\circledR}$, tanto para simular a zona perfurada quanto no restante do estrato de sal. Este elemento tem as seguintes características: 
C: continuum stress/displacement - meio contínuo em análises de tensão/deslocamento;

AX: axisymmetric - axissimétrico;

4: número de nós.

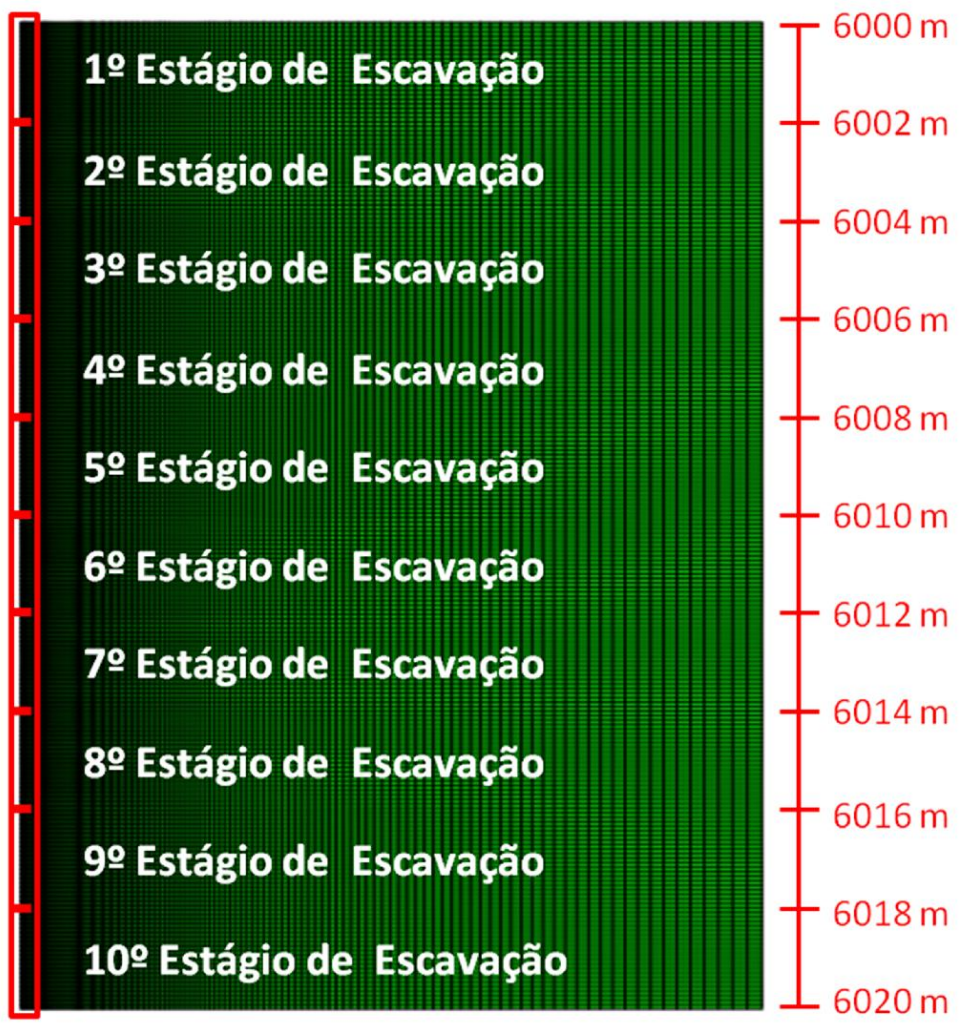

Figura 3-29 - Estágios para a escavação do poço de petróleo em evaporito.

A simulação do modelo axissimétrico foi dividida em 21 etapas ou steps. A primeira etapa refere-se ao uso da função geostática do Abaqus ${ }^{\circledR}$, em que são instaladas as tensões in situ. A segunda e todas as demais etapas pares (etapa 2, etapa 4, etapa 6,..., etapa 20) correspondem à desativação dos elementos que compõem o poço, simulando a escavação (2 m em cada etapa). Nelas foram simuladas as respostas elásticas e a introdução das pressões provocadas pelo fluido de perfuração na parede do poço. A terceira e as demais etapas ímpares (etapa 3, etapa 5, etapa 7,..., etapa 19) correspondem à fase de fluência. Nessas etapas foi considerado um tempo de estudo de 900 segundos, antecedendo cada escavação. Por fim, na vigésima primeira etapa o tempo considerado para o estudo de fluência foi diferente das anteriores, sendo simulado um período de 30 dias após a última escavação, tempo máximo que antecede a instalação do revestimento. 
Os steps são realizados para um determinado peso de fluido de perfuração. O mesmo procedimento é realizado levando em consideração os diferentes pesos do fluido, de 9 ppg a 13 ppg, variando a cada 1ppg (Tabela 3-2).

A pressão do fluido de perfuração é introduzida na parede do poço escavado e varia com a profundidade. Como exemplo, tem-se que a pressão exercida pelo fluido de perfuração de peso de 9 ppg, na profundidade de $6000 \mathrm{~m}$ abaixo do nível do mar, é de 63,8 MPa. No decorrer dos $20 \mathrm{~m}$ da profundidade de análise a pressão do fluido varia linearmente, até atingir uma pressão de $64 \mathrm{MPa}$ na cota $6020 \mathrm{~m}$ abaixo do nível do mar.

\subsubsection{Análise das dimensões e refinamento do modelo}

O modelo proposto por Botelho (2008) é um plano $15 \mathrm{~m} \mathrm{x} 20 \mathrm{~m}$, como mostrado anteriormente. Neste trabalho, decidiu-se analisar a influência da dimensão adotada, mantendo a condição da análise do comportamento do evaporito ao longo da perfuração de uma espessura de 20 metros. Desta forma, o estudo da dimensão foi realizado variando a dimensão lateral e mantendo a dimensão vertical constante, para a perfuração do poço de 0,31m de diâmetro. As dimensões analisadas estão representadas na Figura 3-30.

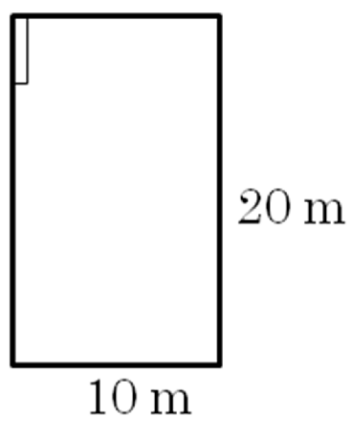

(a)

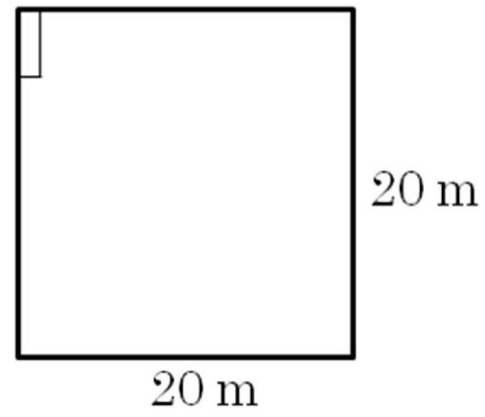

(c)

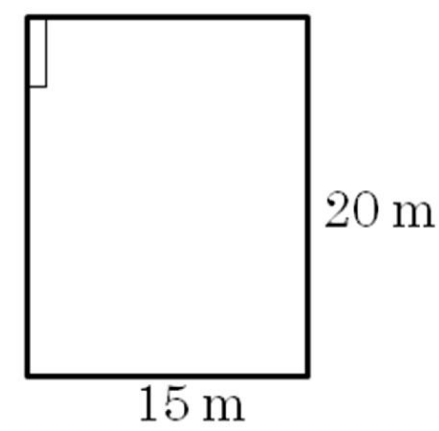

(b)

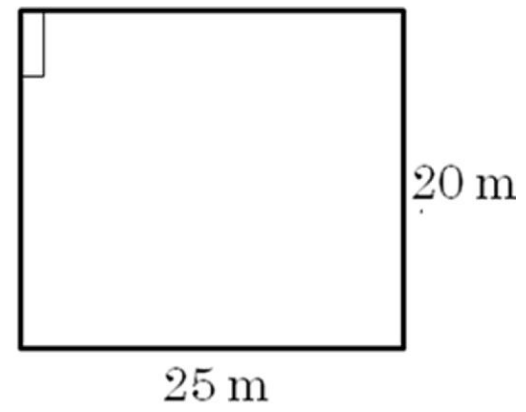

(d)

Figura 3-30 - Dimensões analisadas para o modelo axissimétrico, sem escala: (a) Modelo 1; (b) Modelo 2; (c) Modelo 3 e; (d) Modelo 4. 
No estudo e definição das dimensões e refinamento do modelo, realizou-se a simulação até a terceira etapa, compreendendo a etapa geostática e a escavação do poço, com a obtenção das respostas elásticas e a introdução das pressões do fluido de perfuração, e a etapa de fluência do sal. O eixo das abscissas dos gráficos da Figura 3-31 é uma escala de tempo. Para esta escavação foi analisada um período de $900 \mathrm{~s}$ (15 minutos) de fluência. O peso do fluido de perfuração utilizado para essas análises foi de 9 ppg.

Para este estudo, manteve-se a malha na mesma proporção a fim de observar apenas a influência na variação da dimensão horizontal no modelo proposto. Para isso, foi feita a análise dos deslocamentos radiais no meio do primeiro estágio de escavação, a um metro medido a partir do topo da camada de sal modelada, ou seja, na cota $6001 \mathrm{~m}$ abaixo do nível do mar. O gráfico da Figura 3-31 apresenta os deslocamentos radiais, no sentido do eixo 1, para os quatro modelos propostos.

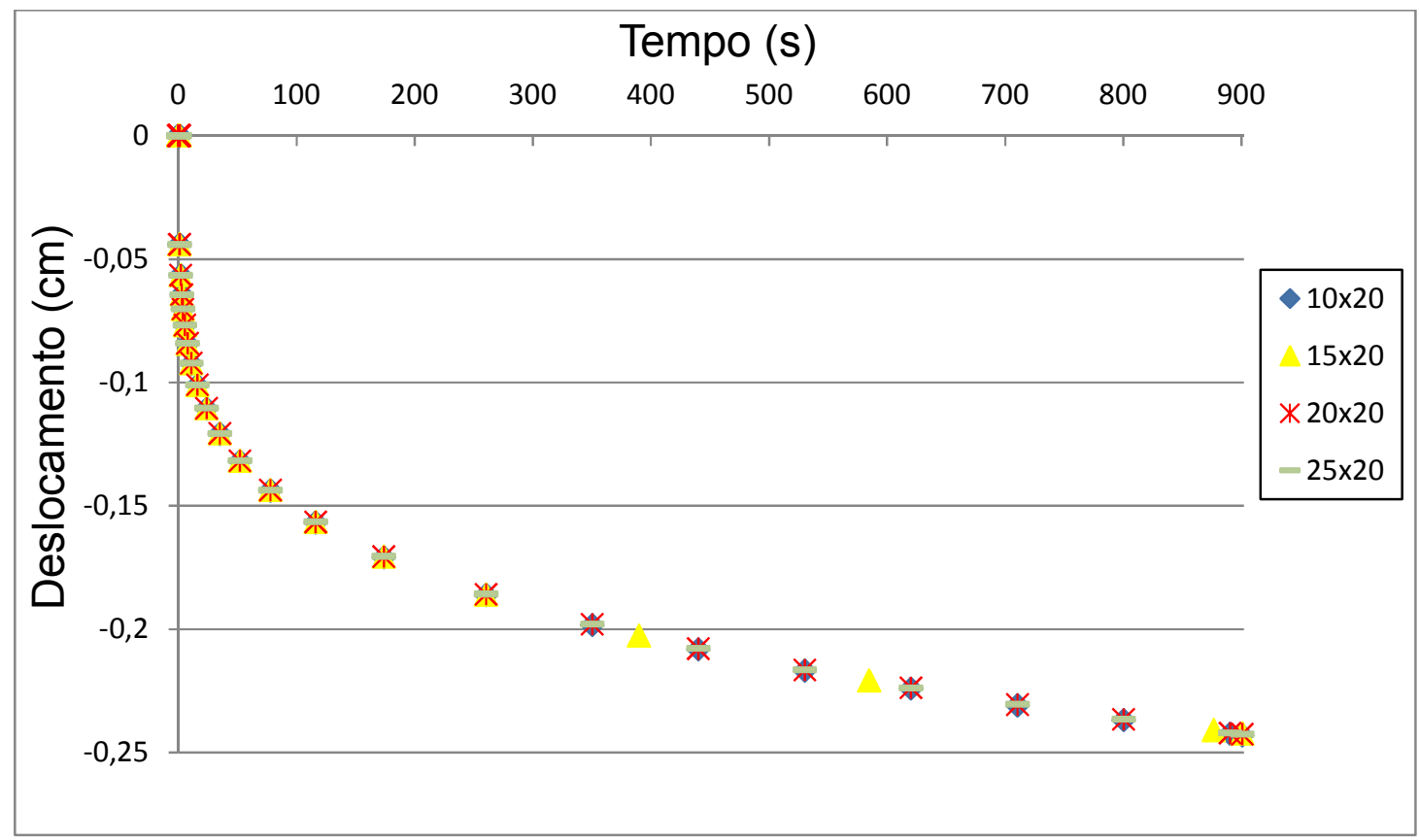

Figura 3-31 - Análise das dimensões para o modelo axissimétrico.

Observando a Figura 3-31, percebe-se que para os quatro modelos analisados, mantendo a profundidade de estudo e variando a dimensão lateral do modelo, para a mesma proporção de refinamento, não há variação significativa nos deslocamentos horizontais na parede do poço. Analisando o erro percentual dos modelos em relação ao modelo 4, o modelo 1 apresentou um erro de $0,2 \%$. Para o modelo 2 e modelo 3 este erro foi de $0,09 \%$ e $0,04 \%$, respectivamente. $\mathrm{O}$ modelo 3 , apresenta menor erro em relação ao modelo 4 , porém com um 
maior custo computacional, já que exige maior número de elementos em sua modelagem. Assim, opta-se por utilizar a geometria do modelo 2 para a análise da perfuração de poço de petróleo em uma seção de estudo com 20 metros de profundidade, mantendo a geometria adotada por Botelho (2008).

Após definir as dimensões do modelo para a simulação da perfuração do poço de petróleo em evaporito, faz-se o estudo da sensibilidade ao refinamento da malha. Para isso, foram realizadas simulações com dez diferentes refinamentos representados na Tabela 3-4, com seus respectivos números de elementos e nós. Para os dez casos analisados foi feito um maior refinamento na malha próxima ao poço, onde se espera encontrar as maiores variações de deslocamentos, deformações e tensões.

Tabela 3-4 - Refinamento do modelo axissimétrico.

\begin{tabular}{ccc}
\hline Refinamento & $\mathrm{N}^{\mathrm{o}}$ de elementos & $\mathrm{N}^{\mathrm{o}}$ de nós \\
\hline Ref. $\mathbf{1}$ & 1840 & 1927 \\
Ref. $\mathbf{2}$ & 6000 & 6156 \\
Ref. $\mathbf{3}$ & 21600 & 21909 \\
Ref. $\mathbf{4}$ & 27000 & 27342 \\
Ref. $\mathbf{5}$ & 51600 & 52059 \\
Ref. $\mathbf{5}$ & 52600 & 53064 \\
Ref. $\mathbf{7}$ & 125200 & 125914 \\
Ref. $\mathbf{8}$ & 134800 & 135538 \\
Ref. 9 & 303200 & 304380 \\
Ref. $\mathbf{1 0}$ & 352000 & 353241 \\
\hline
\end{tabular}

Os deslocamentos radiais no meio do primeiro estágio de escavação, na cota $6001 \mathrm{~m}$ abaixo do nível do mar, para cada condição de refinamento analisado no modelo de $15 \mathrm{~m}$ x 20 m, é representado no gráfico da Figura 3-32. O erro percentual do refinamento 1 em relação ao refinamento 10 é de 25,5\%. Para o refinamento 3 este erro é de 4,4\%. Graficamente, percebe-se que a partir do refinamento 4 não há variação significativa do deslocamento na parede do poço. Considerando o erro percentual para o refinamento 4 , tem-se um erro de $2 \%$, enquanto que o refinamento 8 apresenta um erro de $0,6 \%$.

Os maiores níveis de refinamento exigem um elevado esforço computacional, o qual é muito grande quando comparado com a melhoria no refinamento. Desta forma, optou-se por utilizar o refinamento 4, com 27342 nós, visto que o erro percentual é pequeno, com um 
esforço computacional aceitável para o processamento da simulação.

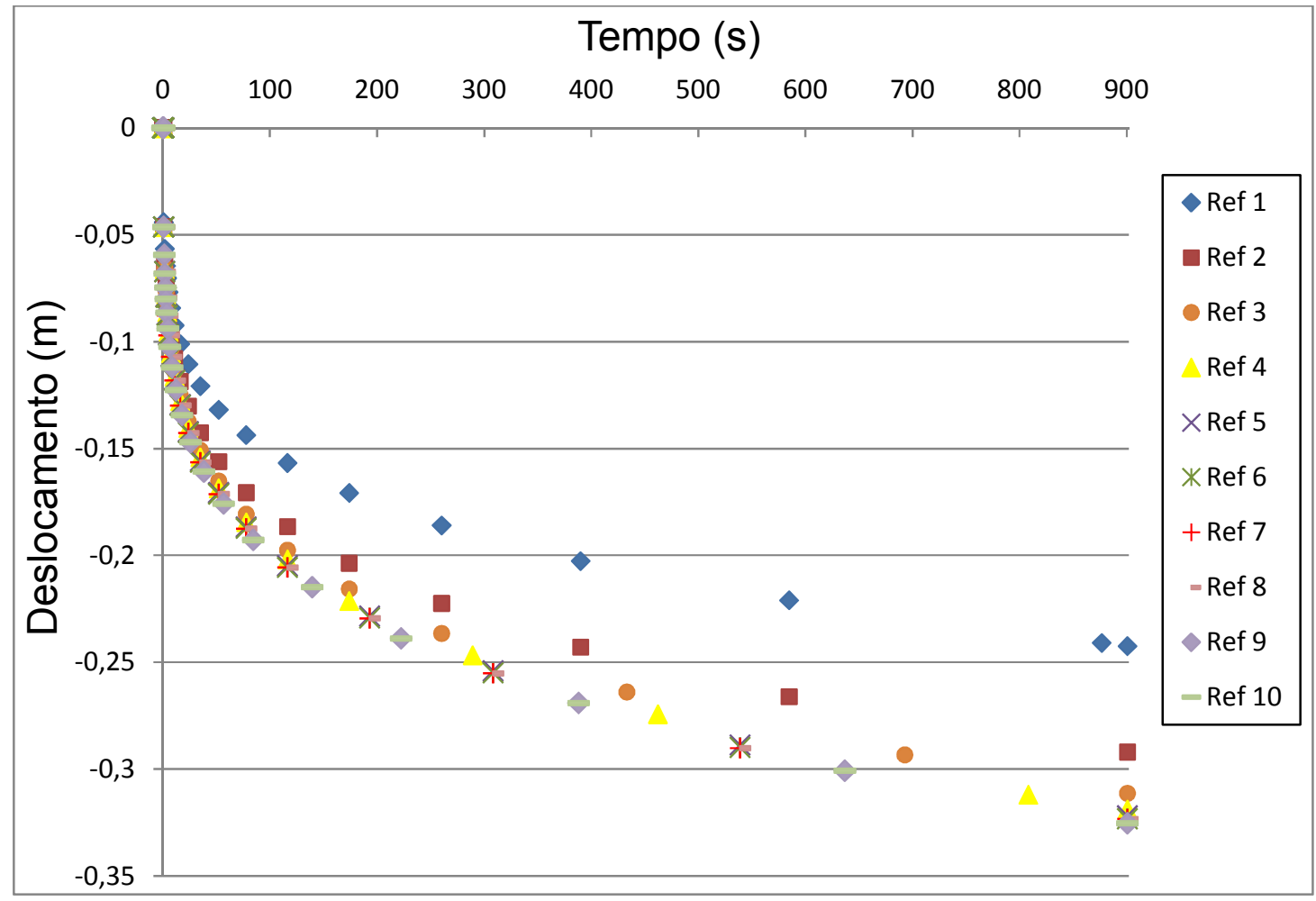

Figura 3-32 - Análise do refinamento para o modelo axissimétrico.

A geometria e o refinamento definidos para as análises do modelo axissimétrico no Abaqus ${ }^{\circledR}$ são comparados com a solução analítica proposta por Panet (1979). Esta solução determina os deslocamentos radiais das paredes de túneis circulares ao longo de seu eixo, a qual leva em consideração a presença da frente de escavação, maciço como elástico e submetido a um carregamento axissimétrico. As equações abaixo representam essa solução:

$\operatorname{Para} Z>0: \quad u_{r}=c_{0}+c_{1} \cdot\left[1-\exp \left(1-\frac{|Z|}{0,7 R}\right)\right]$
Para $Z \leq 0: \quad u_{r}=c_{0}-c_{0} \cdot\left[1-\exp \left(1-\frac{|Z|}{0,7 R}\right)\right]$,

com:

$$
c_{0}=\frac{-\sigma_{0} R h_{0}}{2 G}
$$




$$
c_{1}=\frac{-\sigma_{0} R}{2 G} \cdot\left(1-h_{0}\right)
$$

sendo:

$\sigma_{0}$ a tensão in situ;

$G$ o módulo de cisalhamento do maciço;

$Z$ a distância à frente de escavação;

$R$ o raio do poço; e

$h_{0} \cong \frac{1}{3}$, para o meio elástico isotrópico.

A simulação no Abaqus consistiu apenas nas duas primeiras etapas de análise, sem a presença do fluido de perfuração, sendo a etapa geostática e o primeiro estágio de escavação do poço ( 2 metros). Para isso, considerou-se: $\mathrm{R}=0,155 \mathrm{~m}, \sigma_{0}=107,6 \mathrm{MPa}, v=0,36 \mathrm{e}$ $E=2,04 \mathrm{E}+04 \mathrm{MPa}$.

Como pode ser observado no gráfico da Figura 3-33, os dados dos deslocamentos radiais foram tomados levando em consideração a presença da frente de escavação $(Z>0)$ e a região ainda não escavada $(Z \leq 0)$. Os deslocamentos radiais obtidos pela simulação numérica se ajustam bem aos valores obtidos pela solução de Panet (1979). Com isso, pode-se validar a geometria e o refinamento adotados para o modelo axissimétrico. 


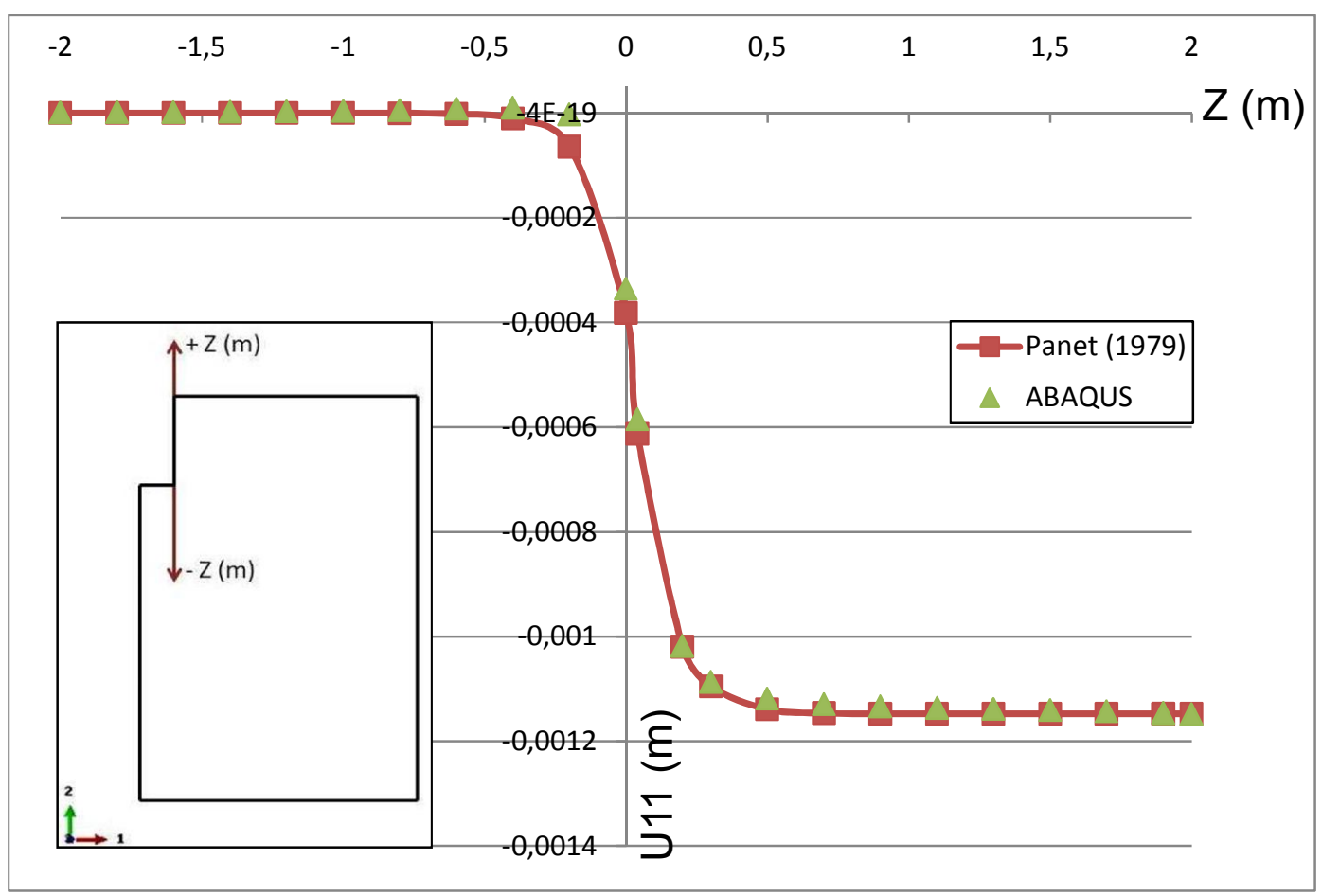

Figura 3-33 - Gráfico comparativo dos deslocamentos radiais obtidos pela solução analítica (Panet, 1979) e pelo Abaqus ${ }^{\circledR}$.

\subsubsection{Resultados e discussões da simulação do poço de petróleo em evaporito}

O modelo axissimétrico do poço analisado correspondeu a uma malha de elementos finitos 2D, com dimensões de $15 \mathrm{~m}$ (largura) x $20 \mathrm{~m}$ (altura), composta por 27342 nós e 27000 elementos do tipo CAX4, dos quais 864 elementos foram utilizados para representar a região do poço a ser escavada. A Figura 3-34 apresenta a malha de elementos finitos para o modelo axissimétrico. A região próxima ao poço apresenta um maior refinamento, diminuindo à medida que se afasta da parede do poço, como mostrado na Figura 3-34a. A Figura 3-34b mostra a malha com o primeiro estágio de escavação executado e destacando a região onde ocorrem as demais etapas de perfuração. O nó em destaque na parede do poço, apresentado na Figura 3-34c, representa o nó em que são tomados os dados para análise do modelo axissimétrico após a realização de todas as etapas de análise, localizado na cota $6011 \mathrm{~m}$ abaixo do nível do mar.

Para este modelo foram realizadas análises de deslocamentos, deformações e tensões, utilizando diferentes pesos do fluidos de perfuração. Os resultados do modelo axissimétrico são compatíveis com os apresentados por Botelho (2008). 


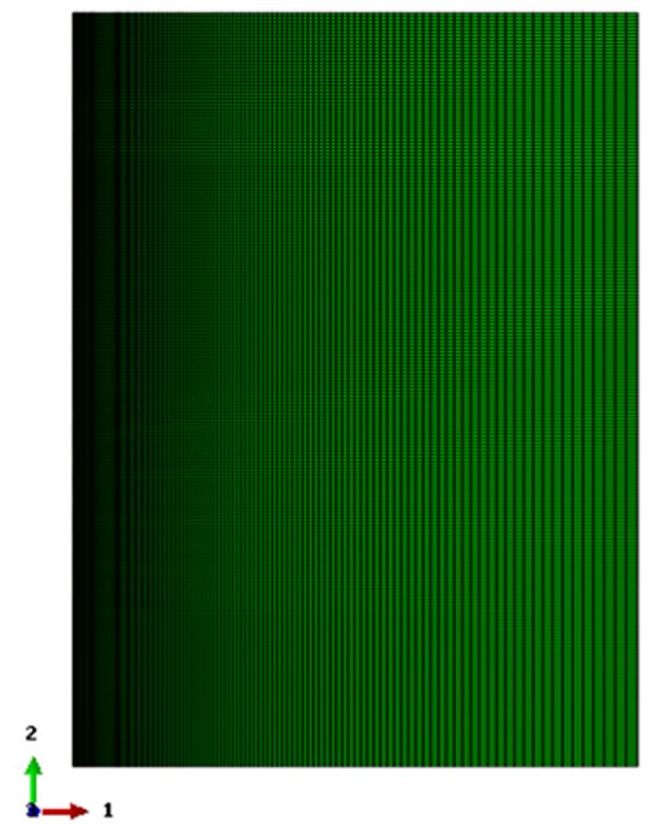

(a)

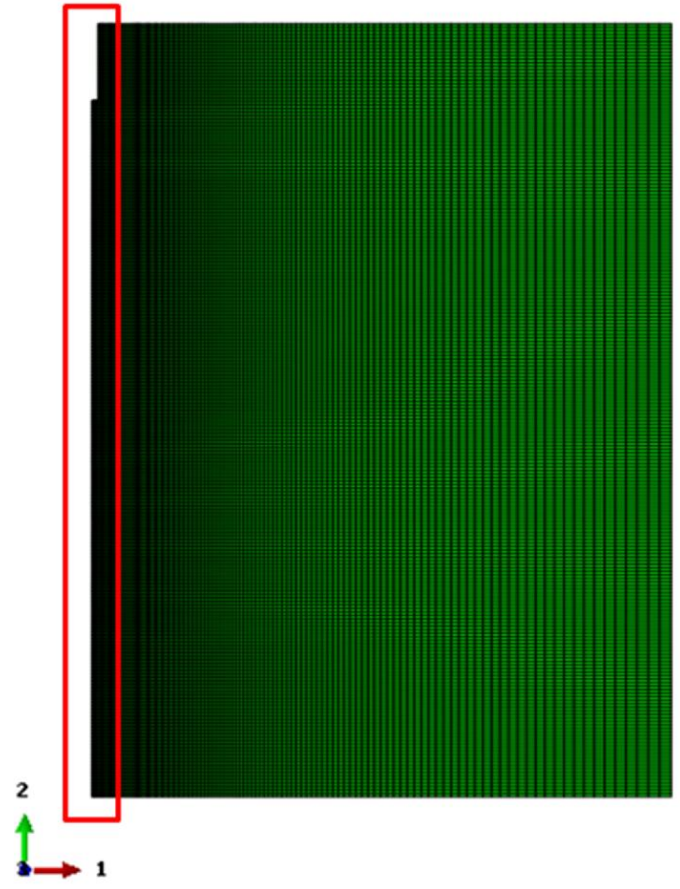

(b)

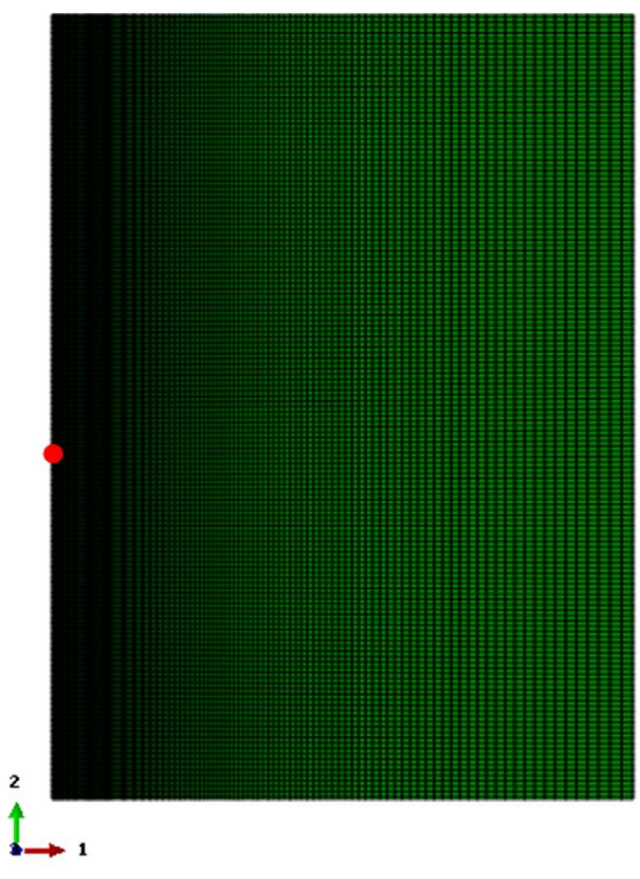

(c)

Figura 3-34 - Malha de elementos finitos utilizada na simulação numérica: (a) vista geral da malha; (b) detalhe da região a ser escavada, já com a realização da escavação do primeiro estágio (2 metros); (c) destaque em um nó de análise na parede do poço no meio do sexto estágio de escavação. 


\subsubsection{Deslocamentos}

As análises dos deslocamentos radiais foram realizadas considerando os dados em um nó na parede do poço a 11 metros do topo do estrato salino analisado, ou seja, no meio do $6^{\circ}$ estágio de escavação. As medições foram feitas para diferentes pesos do fluido em um período de 30 dias após a última escavação, as quais estão representadas na Figura 3-35.

A Figura 3-35 mostra que quando se aplica um menor peso de fluido de perfuração, o fechamento do poço é maior. Tal fato é evidenciado pela maior diferença entre as tensões in situ e aquelas aplicadas à parede do poço devido ao peso do fluido de perfuração. Quando se utiliza o peso do fluido de perfuração de $10 \mathrm{ppg}$, tem-se um fechamento do poço de $1,2 \mathrm{~cm}$, enquanto que para um peso do fluido de $12 \mathrm{ppg}$ este fechamento é de $0,4 \mathrm{~cm}$. Ou seja, ao utilizar o peso do fluido de $12 \mathrm{ppg}$, tem-se um fechamento do poço correspondente a 33,3\% do valor do fechamento quando aplicado o peso de fluido de $10 \mathrm{ppg}$.

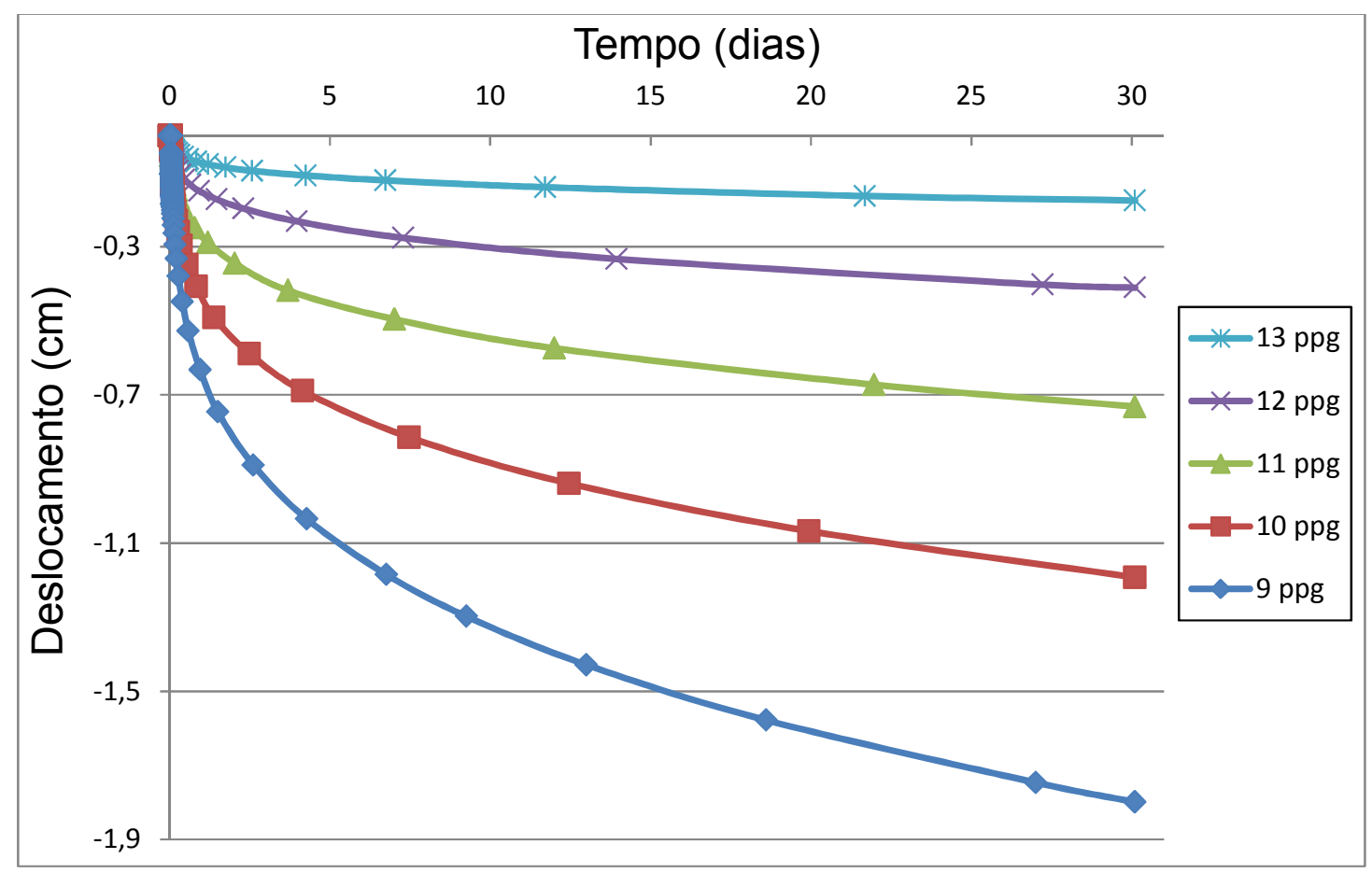

Figura 3-35 - Fechamento do poço para os diferentes pesos do fluido de perfuração em um período de 30 dias após a última escavação.

Os deslocamentos mais significativos ocorrem no primeiro dia após a escavação e independe do peso do fluido de perfuração utilizado, conforme mostrado na Figura 3-36. Percebe-se que em um dia após a perfuração, o poço teve $36,5 \%$ do fechamento total ocorrido 
em um período de um mês, quando utilizado o peso de fluido de 12 ppg. Assim, reafirma-se a importância da escolha do fluido de perfuração a ser aplicado durante a perfuração de poços de petróleo.

Ainda, observando a Figura 3-36, nota-se que os deslocamentos iniciam após 4500 segundos (0,05 dias). Este intervalo corresponde ao momento em que a simulação da perfuração realizou o $6^{\circ}$ estágio de escavação, ultrapassando o ponto de análise $(6011 \mathrm{~m})$.

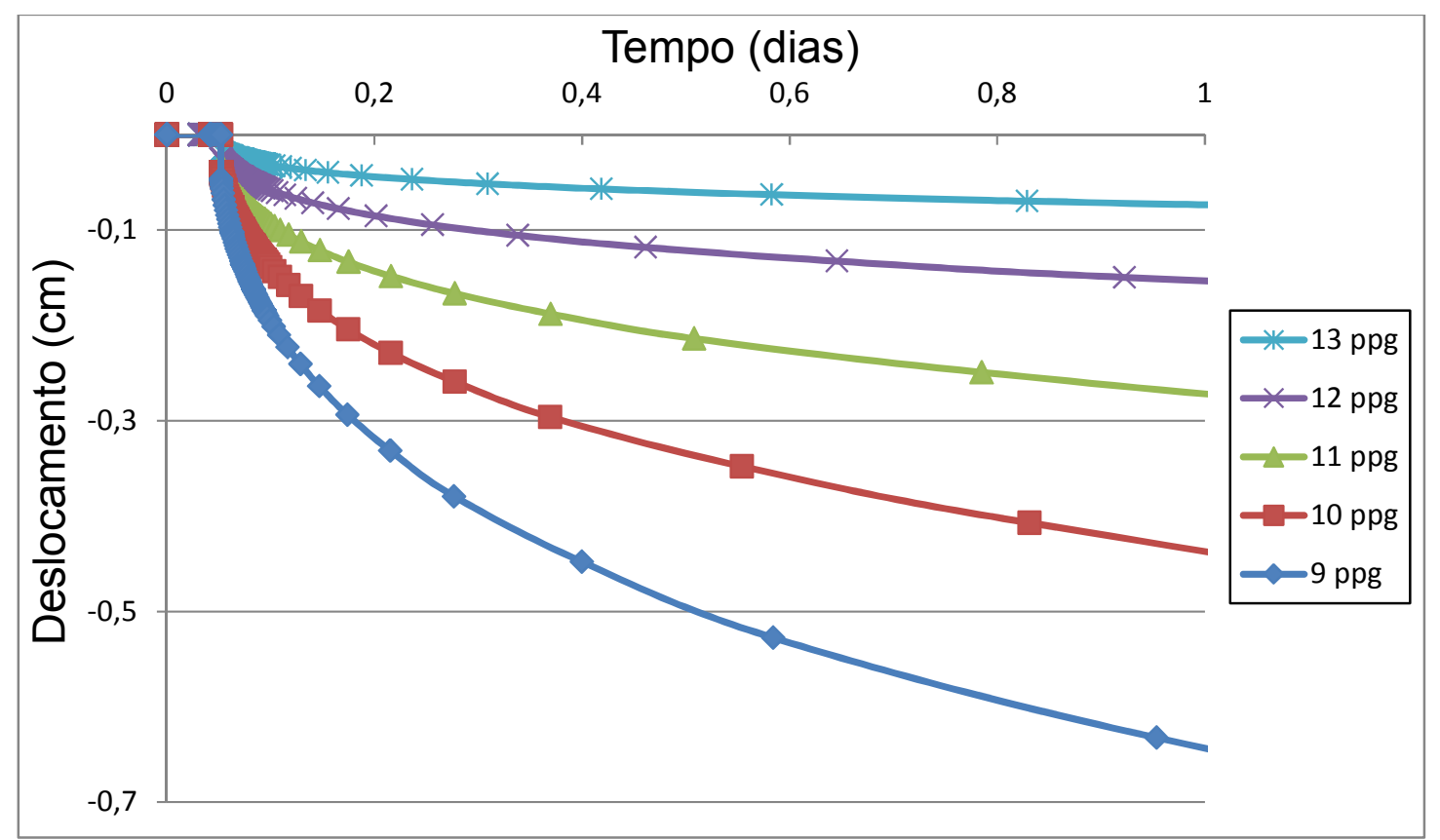

Figura 3-36 - Fechamento do poço para os diferentes pesos do fluido de perfuração em um período de 1 dia após a última escavação.

O gráfico da Figura 3-37 apresenta os deslocamentos radiais considerando apenas a solução elástica e, também, considerando a solução elástica e a fluência em um dia e em um mês após a última escavação do estrato salino modelado. Utiliza-se o mesmo ponto de análise na parede do poço, na cota $6011 \mathrm{~m}$ abaixo do nível do mar. Como as tensões iniciais aumentam com a profundidade, assim como a pressão do fluido de perfuração, os deslocamentos variam para cada camada escavada.

A Figura 3-37 mostra que os deslocamentos gerados apenas pela solução elástica do sal são pequenos quando comparados com os deslocamentos causados por fluência. Ainda, observa-se que nos primeiros instantes após a perfuração do poço, os deslocamentos são maiores que os demais. Para um fluido com peso de 11 ppg, o deslocamento causado apenas pela solução elástica foi de $0,03 \mathrm{~cm}$, enquanto que para a solução elástica e fluência de um dia esse valor foi de $0,29 \mathrm{~cm}$. Ainda, considerando um período de fluência de um mês após a 
última escavação, esse deslocamento foi de $0,74 \mathrm{~cm}$. Ou seja, o fechamento causado para um período de 1 dia de fluência corresponde a quase $40 \%$ do fechamento total dado em um período de um mês, enquanto que a solução elástica representa pouco mais de $4 \%$ desse fechamento. Esse fato corrobora a importância da consideração da fluência, principalmente nos primeiros instantes após a perfuração.

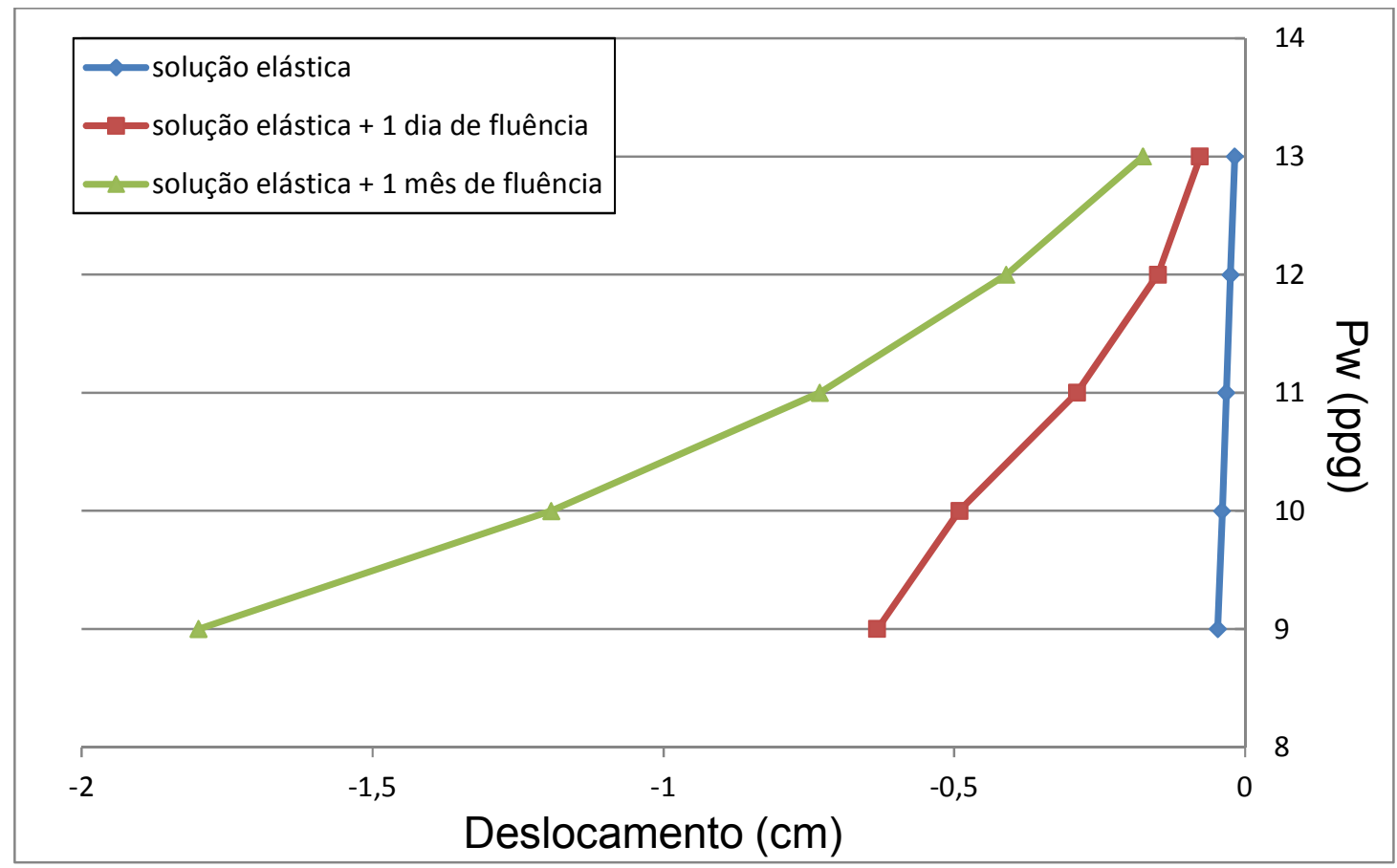

Figura 3-37 - Fechamento do poço para os diferentes pesos do fluido de perfuração considerando: solução elástica, solução elástica e fluência em 1 dia e em 30 dias, após a última escavação.

A Figura 3-38 representa os deslocamentos no sentido do eixo 1, apresentada por uma escala de cores no Abaqus ${ }^{\circledR}$, para o modelo axissimétrico com peso do fluido de perfuração de 12 ppg, em um período de um mês após a última escavação. 

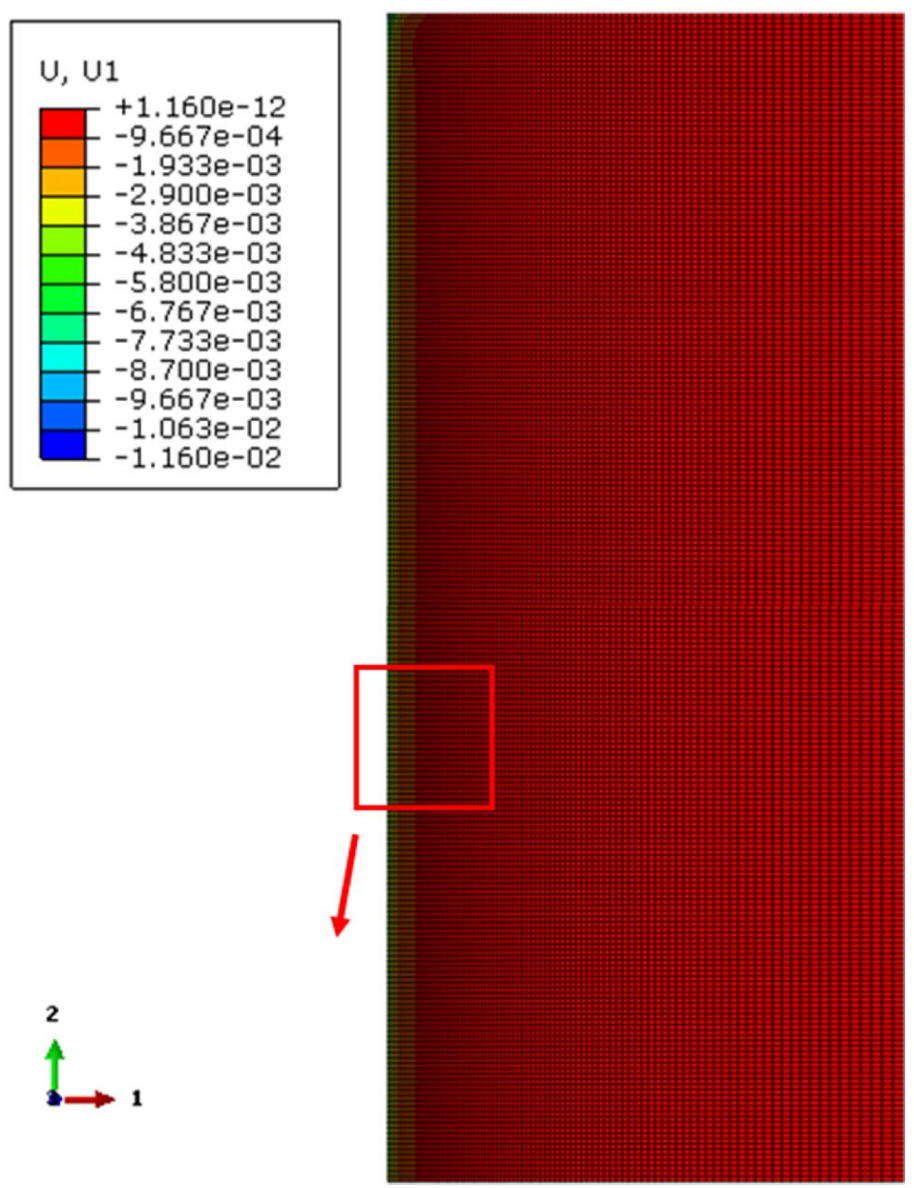

(a)

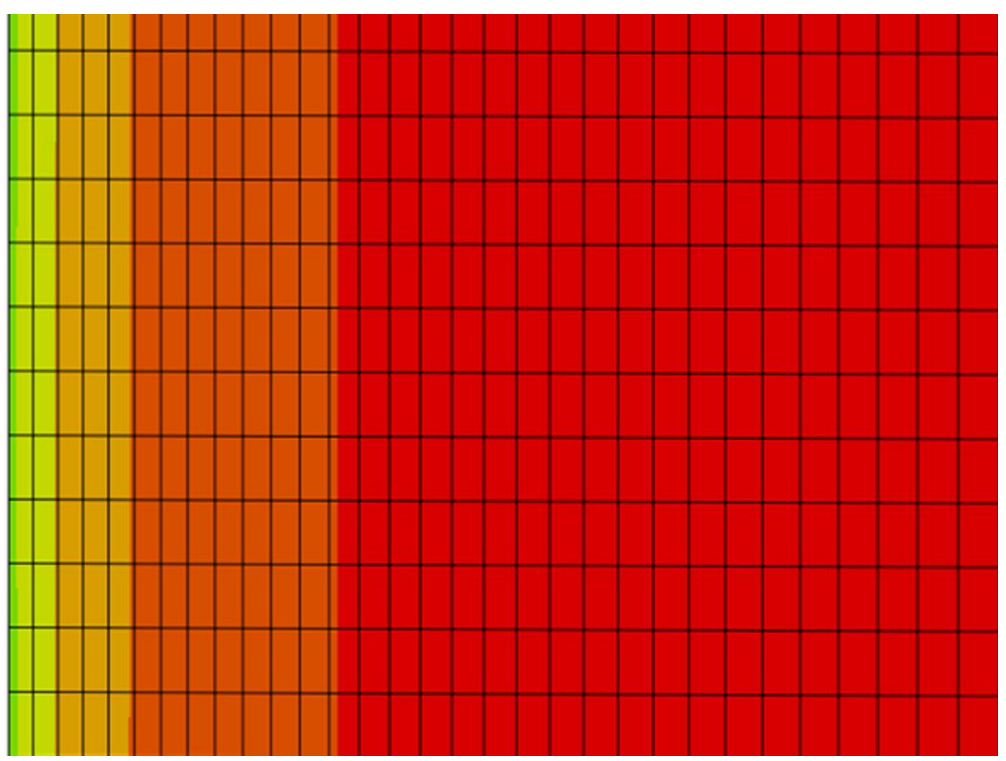

(b)

Figura 3-38 - Deslocamento em metros no sentido do eixo 1 depois de 30 dias: (a) vista geral dos deslocamentos; (b) zoom na região ao redor do poço próxima a cota 6011 abaixo do nível do mar. 


\subsubsection{Deformações}

As análises de deformações radiais na parede do poço foram realizadas considerando a solução elástica e a fluência, para os diferentes pesos do fluido de perfuração. A Figura 3-39 apresenta as deformações radiais para um período de fluência de 30 dias após a última escavação. Ainda, na Figura 3-40, foi observada a evolução das deformações para um período de um dia de fluência. Os cálculos de deformações foram feitos na parede do poço, no meio do $6^{\circ}$ estágio de escavação, na profundidade de 11 metros do topo do estrato salino simulado.

Assim como observado nas análises de deslocamentos radiais, percebe-se que as simulações realizadas com menores pesos do fluido de perfuração apresentam maiores deformações na parede do poço. Para um período de 30 dias a deformação radial na parede do poço, utilizando um fluido com peso igual a $11 \mathrm{ppg}$, foi de 3,9\%, enquanto que para um fluido de 13 ppg essa deformação é de $0,94 \%$. Uma diferença considerável apenas em elevar o peso do fluido em 2 ppg.

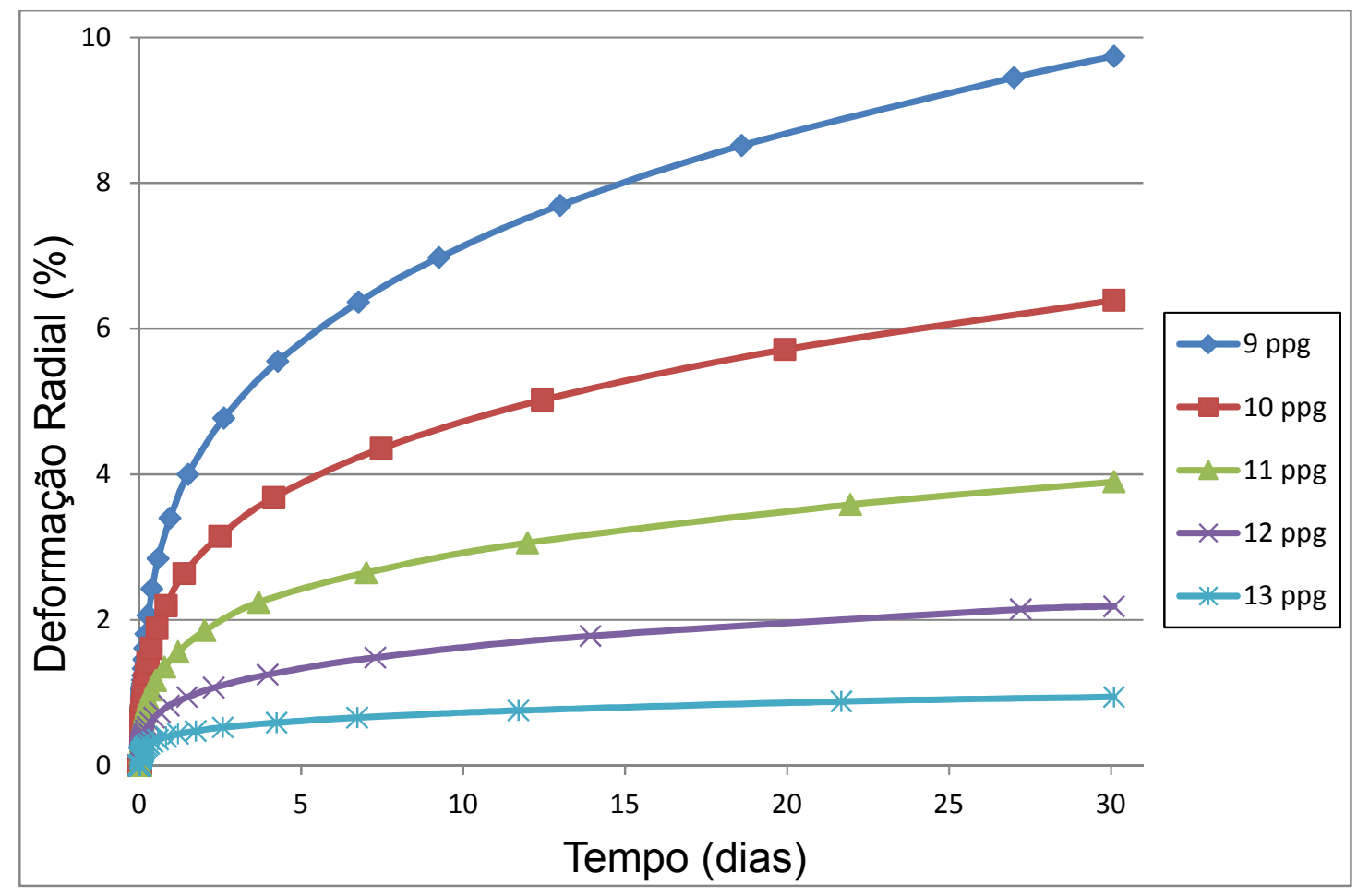

Figura 3-39 - Deformações radiais na parede do poço em um período de 30 dias após a última escavação, para os diferentes pesos do fluido de perfuração.

A Figura 3-40 apresenta as deformações radiais após um período de fluência de um dia. As deformações iniciaram no instante de 4500 segundos (0,05 dias) após o início da 
escavação do estrato salino analisado. Este tempo corresponde ao momento em que a perfuração ultrapassou o ponto de análise (11 metros do topo do estrato salino modelado).

Observando a Figura 3-40, percebe-se que as deformações radiais são mais acentuadas no primeiro dia de fluência. Como exemplo, tem-se que para um fluido com peso de 9 ppg a deformação em um dia é de 3,4\%, enquanto que para um período de fluência de 30 dias após a última escavação, essa deformação é de 9,74\%. Ou seja, em um dia ocorreu $35 \%$ da deformação radial total no período de 30 dias. Ainda, realizando a mesma simulação com o fluido de perfuração com peso de 13 ppg, maior peso analisado, a deformação em 1 dia $(0,43 \%)$ corresponde a $45,7 \%$ da deformação radial total no período de 30 dias $(0,94 \%)$.

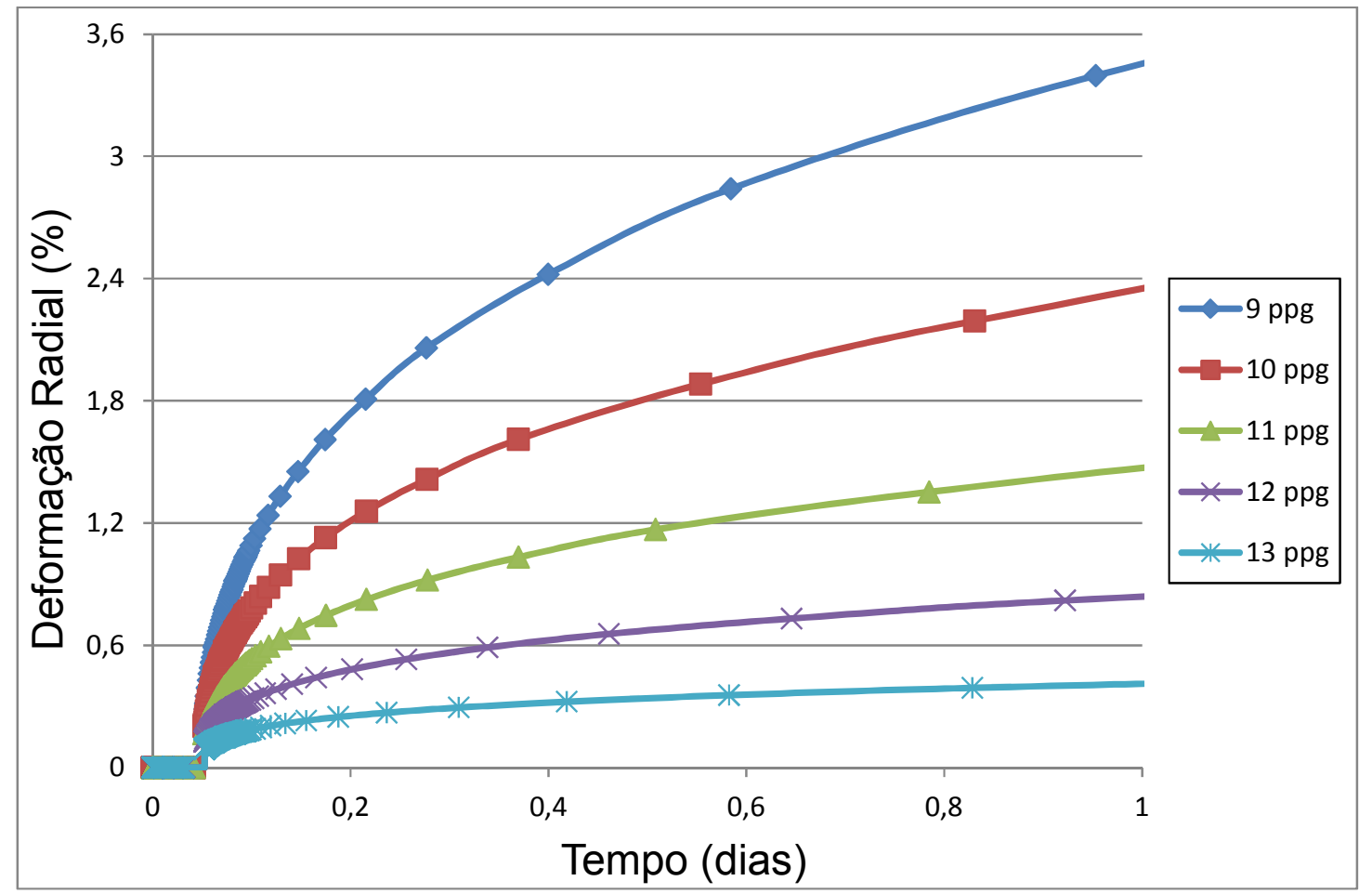

Figura 3-40 - Deformações radiais na parede do poço em um período de um dia após a última escavação, para os diferentes pesos do fluido de perfuração.

Utilizando o mesmo ponto de análise, no meio do $6^{\circ}$ estágio de escavação, pode-se observar a influência dos diferentes pesos de fluido utilizados nas deformações elásticas instantâneas, deformações por fluência do sal em um período de um dia e um mês após a última escavação, representados na Figura 3-41.

Observa-se que as deformações elásticas instantâneas são desprezíveis quando comparadas as deformações causadas pela fluência do sal. Ainda, percebe-se que as deformações são maiores nos primeiros instantes após a perfuração, para qualquer fluido 
utilizado. Ao analisar as deformações quando utilizado o fluido de $11 \mathrm{ppg}$, nota-se que a deformação elástica instantânea corresponde a 4,3 \% da deformação radial total em um período de um mês, enquanto que em um dia ocorreu $40 \%$ dessa deformação.

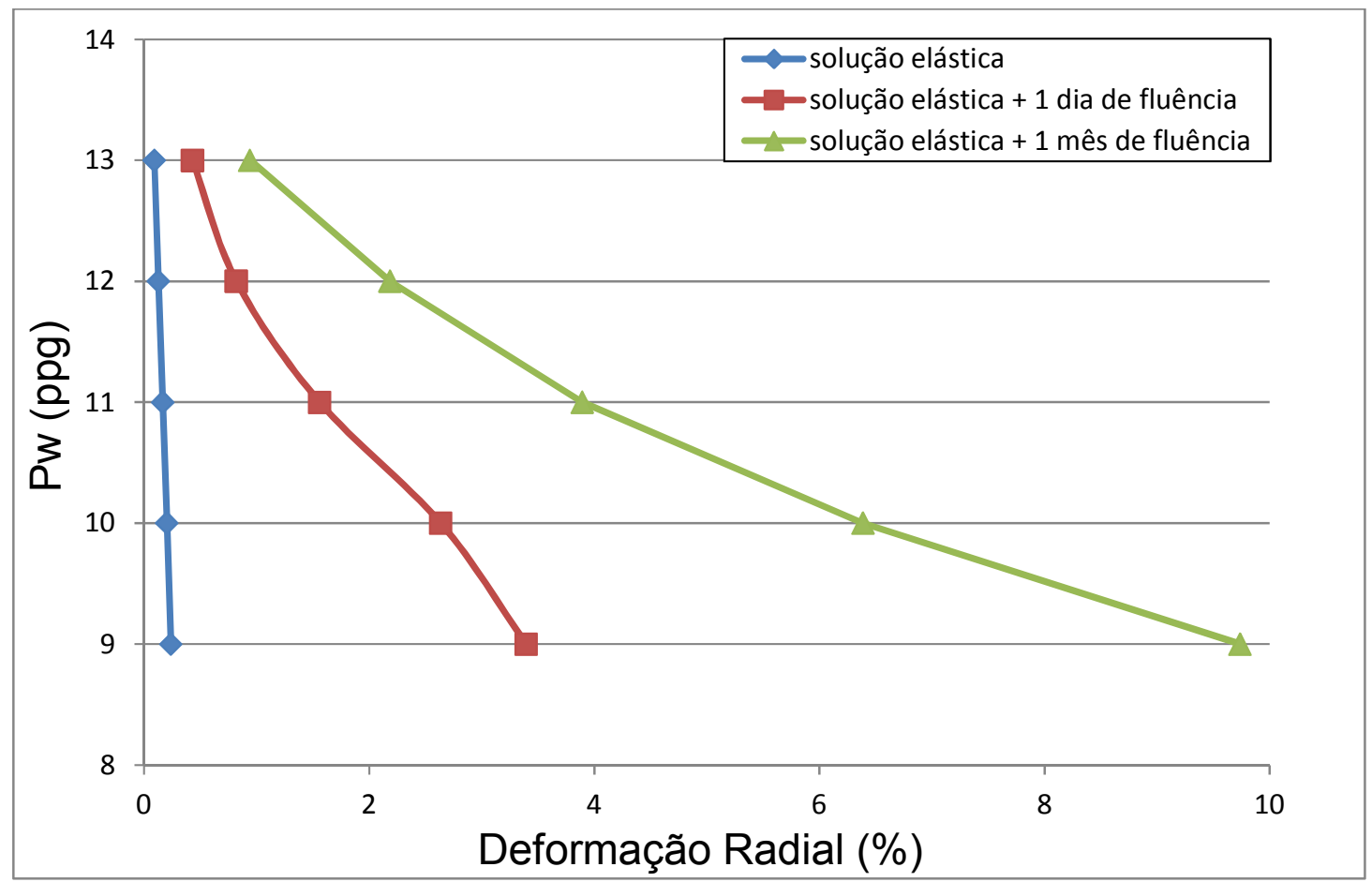

Figura 3-41 - Deformação radial considerando: solução elástica, solução elástica e fluência em 1 dia e em 30 dias após a última escavação, para os diferentes pesos do fluido de perfuração.

A Figura 3-42 representa as deformações no sentido do eixo 1, apresentada por uma escala de cores no Abaqus ${ }^{\circledR}$, com peso do fluido de perfuração de 12 ppg, em um período de um mês após a última escavação. 


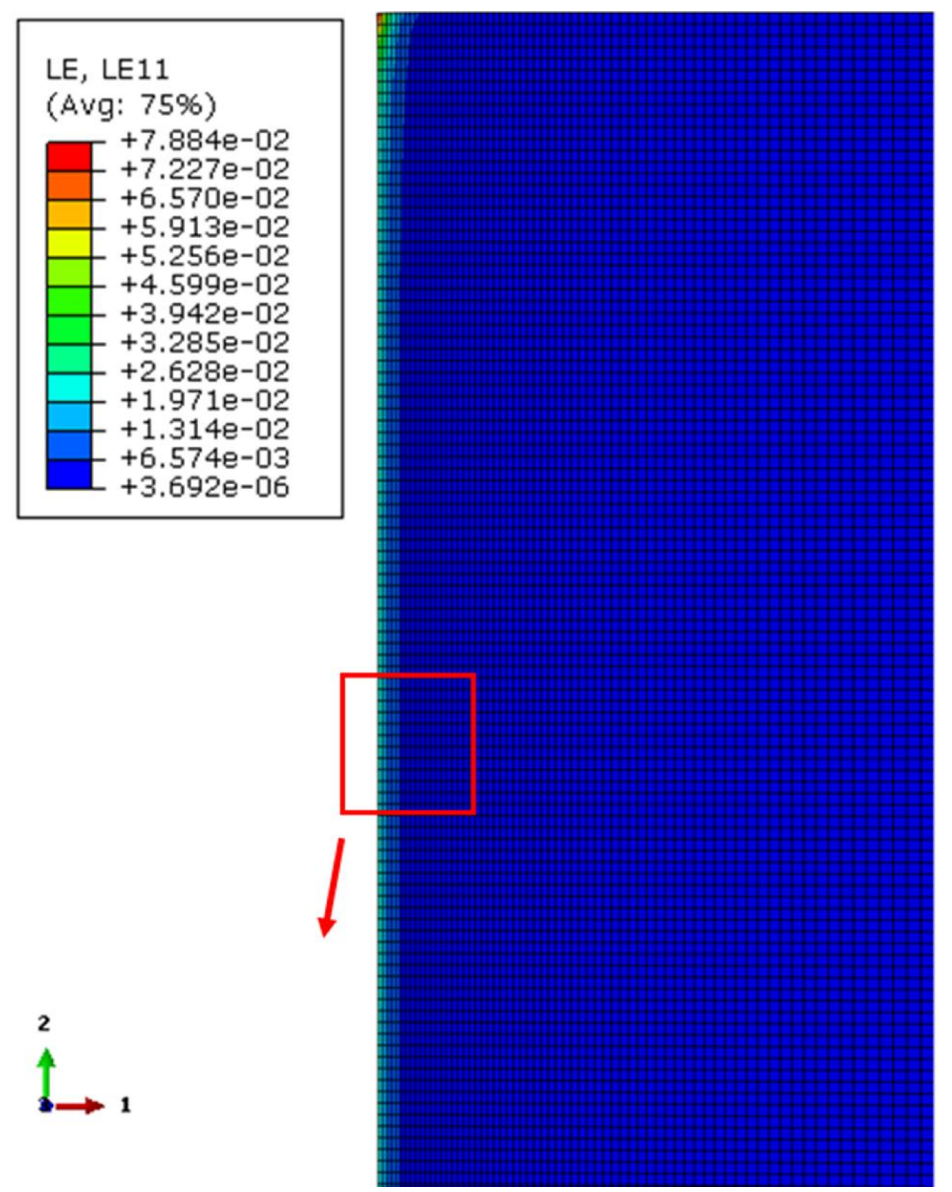

(a)

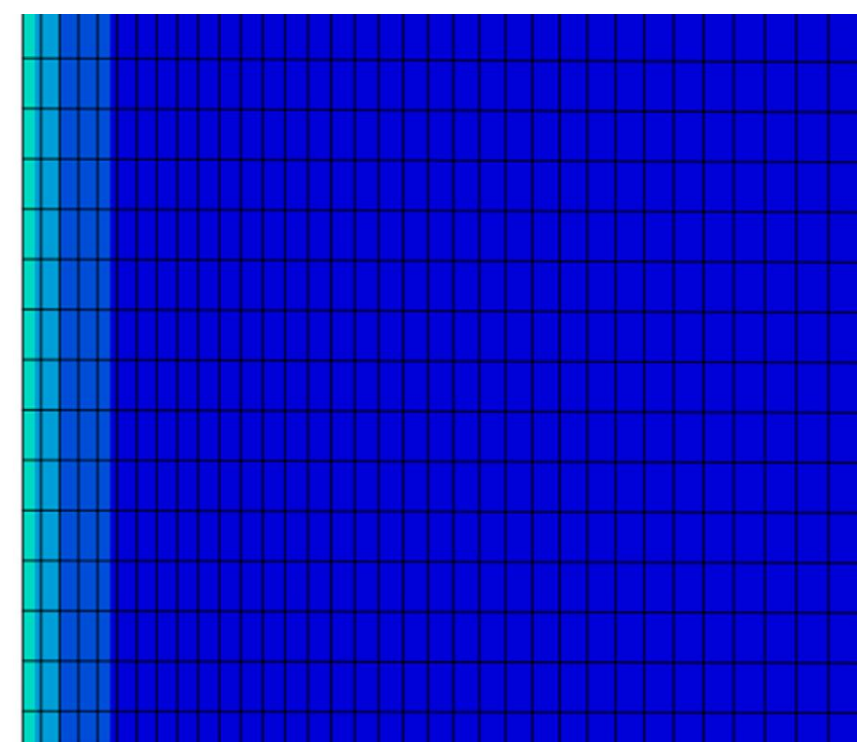

(b)

Figura 3-42 - Deformações no sentido do eixo 1 em um período de 30 dias após a última escavação: (a) vista geral das deformações; (b) zoom na região ao redor do poço próxima a cota 6011 abaixo do nível do mar. Para obter os valores em porcentagem, deve-se multiplicar os resultados apresentados pelo Abaqus ${ }^{\circledR}$ por 100 . 


\subsubsection{Tensões}

A Figura 3-43 apresenta as tensões radiais ao redor do poço considerando um período de fluência de um mês após a última escavação, para diferentes fluidos de perfuração. A análise é realizada a partir da parede do poço $(r / R=1)$ até uma distância de 60 vezes o raio do poço $(r / R=60)$.

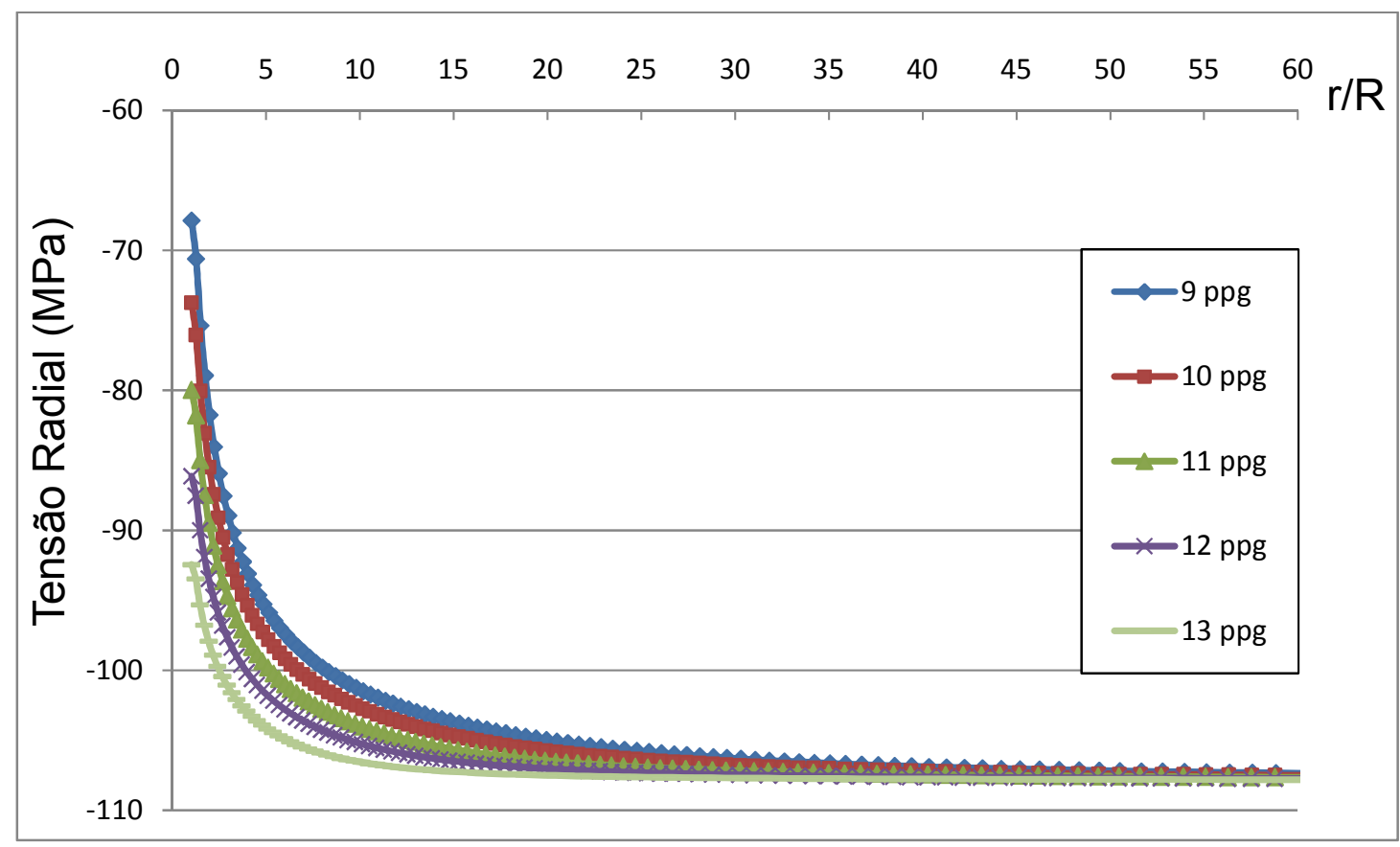

Figura 3-43 - Tensões radiais ao redor do poço utilizando os diferentes pesos do fluido de perfuração em um período de fluência de 30 dias após a última escavação.

Ao analisar o gráfico da Figura 3-43, pode-se constatar que as tensões radiais praticamente igualam-se às tensões in situ nas regiões mais remotas do poço, independentemente do peso do fluido utilizado. Porém, quanto maior o peso do fluido de perfuração menor a distância necessária para que as tensões se igualem às tensões iniciais (107,6 MPa). Tal fato é melhor representando graficamente na Figura 3-44, com as tensões radiais para o fluido de menor e maior peso. Observa-se que para um peso de fluido de $9 \mathrm{ppg}$ as tensões radiais se estabilizam a uma distância de 45 vezes o raio do poço, enquanto que para um peso de fluido de 13 ppg uma distância de 25 vezes o raio do poço é suficiente para que as tensões radiais se estabilizem com às tensões iniciais. Este fato ocorre porque as tensões provocadas pelo fluido de perfuração de 9 ppg $(63,9 \mathrm{MPa})$ na parede do poço são mais distantes das tensões in situ (107,6 MPa), enquanto que as tensões provocadas pelo 
fluido de perfuração de 13 ppg (91,1 MPa) se aproximam das tensões iniciais. Os valores das pressões dos fluidos se referem a profundidade de análise de $6011 \mathrm{~m}$ abaixo do nível do mar.

As tensões radiais na parede do poço deveriam ser iguais às pressões provocadas pelos fluidos de perfuração. Porém, pequenas diferenças são encontradas, já que os valores são calculados nos pontos de integração de cada elemento e, por meio da interpolação linear são obtidas as tensões nos nós dos elementos.

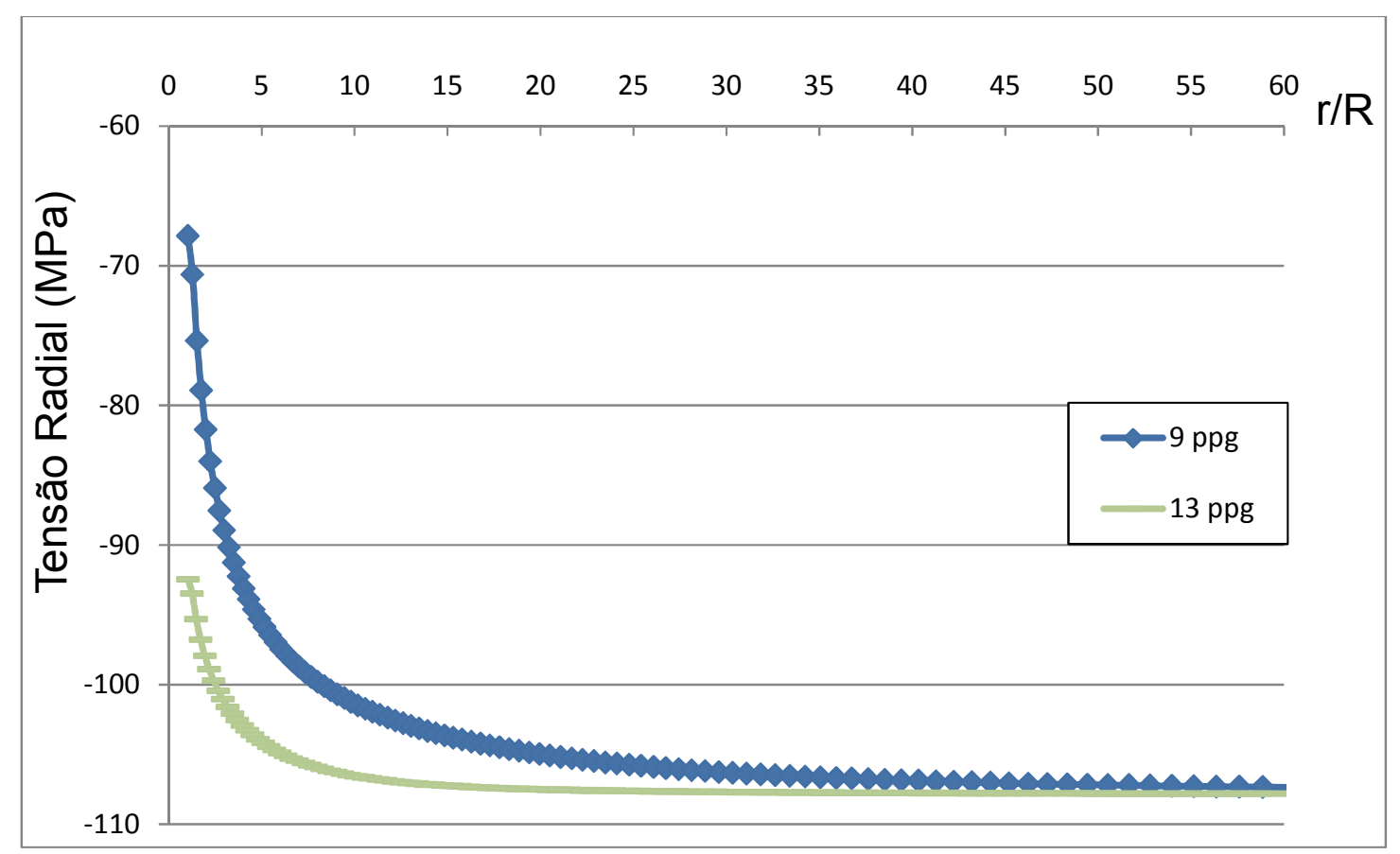

Figura 3-44 - Tensões radiais ao redor do poço utilizando os pesos de fluido de 9 ppg e 13 ppg, em um período de fluência de 30 dias após a última escavação.

Ao analisar as tensões tangenciais na parede do poço representadas na Figura 3-45, pode-se também perceber que nas regiões mais remotas ao poço, as tensões tangenciais decorrentes da escavação praticamente se igualam às tensões in situ, independentemente do peso do fluido utilizado. Ainda, constata-se que quanto menor o peso do fluido de perfuração utilizado na simulação, maior é a perturbação das tensões no corpo salino e, assim, maior a distância necessária para que as tensões se igualem às tensões iniciais. 


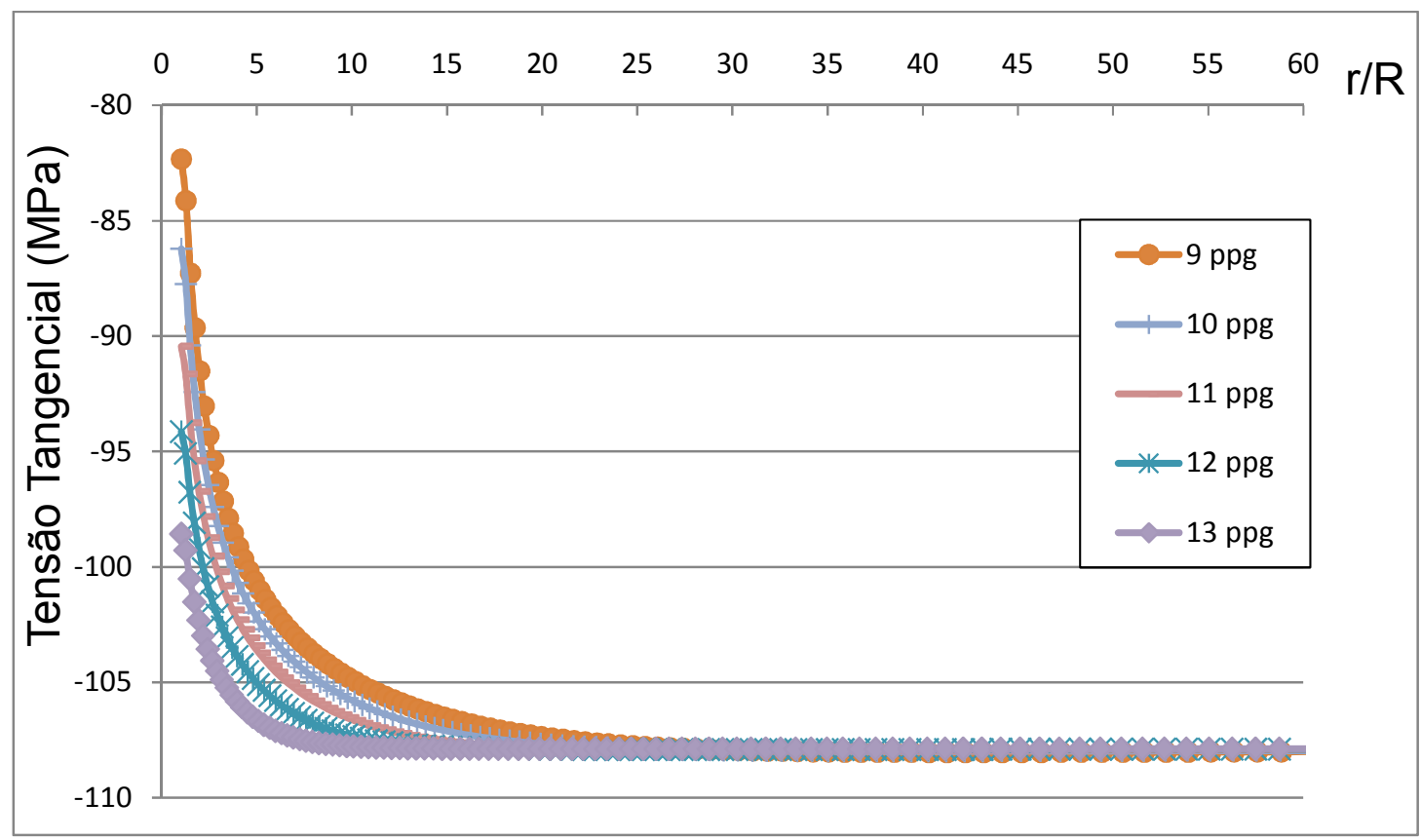

Figura 3-45 - Tensões tangenciais ao redor do poço utilizando os diferentes pesos do fluido de perfuração.

A Figura 3-46 representa as tensões no sentido do eixo 1, apresentada por uma escala de cores no Abaqus ${ }^{\circledR}$, com peso do fluido de perfuração de 12 ppg, em um período de um mês após a última escavação. 


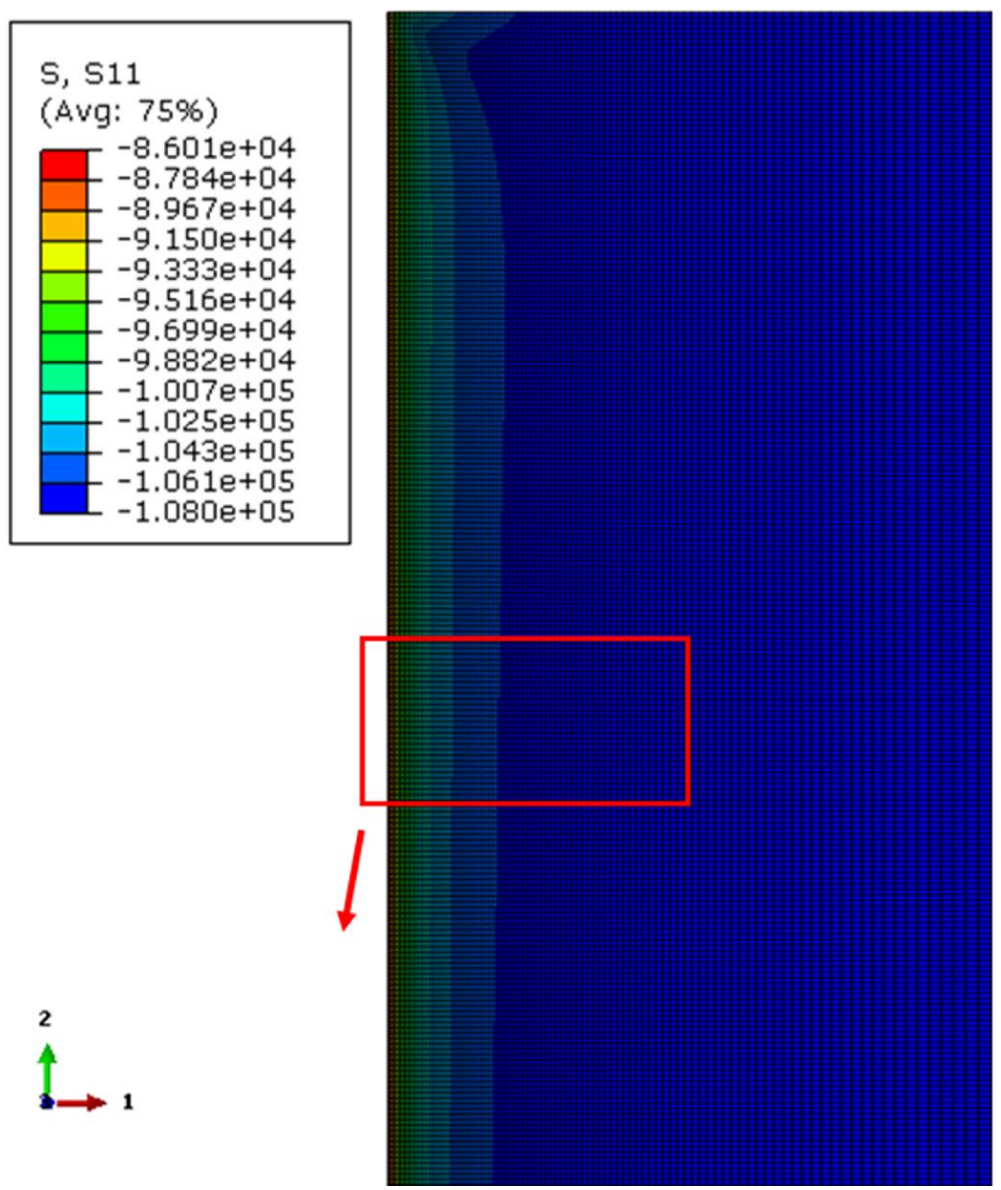

(a)

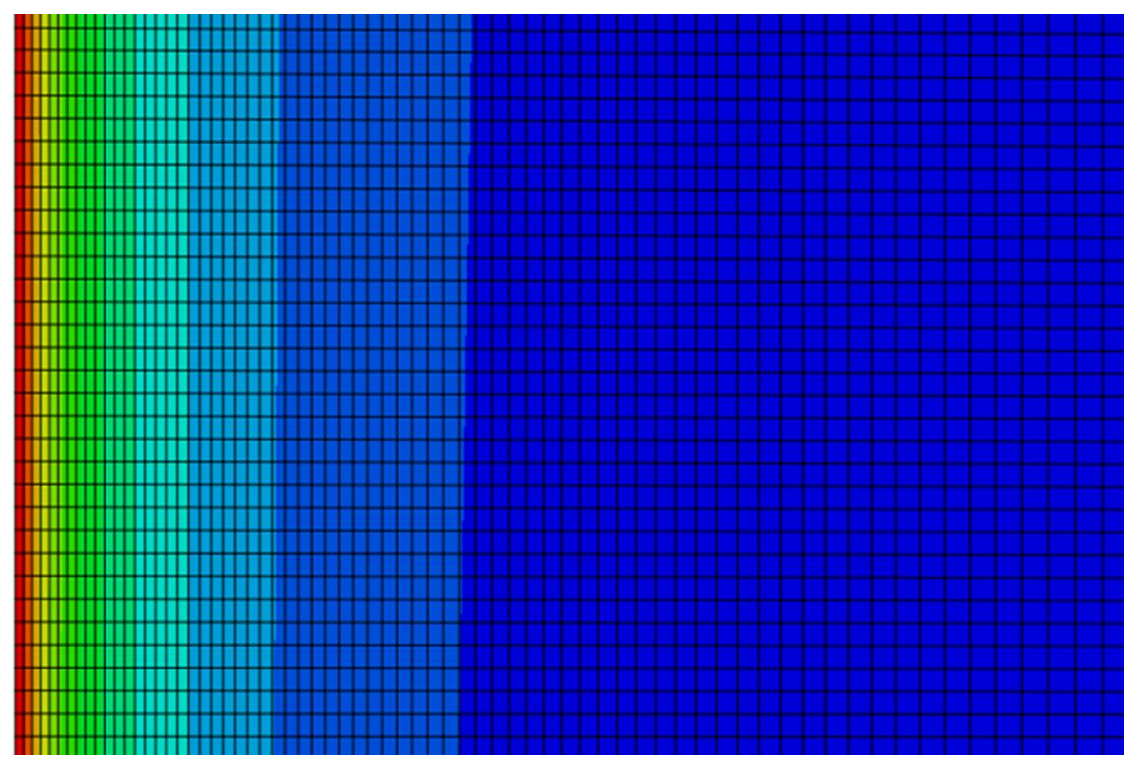

(b)

Figura 3-46 - Tensões radiais ao redor do poço em $\mathrm{kPa}$ em um período de 30 dias após a última escavação: (a) vista geral das tensões radiais; (b) zoom na região ao redor do poço próxima a cota 6011 abaixo do nível do mar. 
Capítulo 4

\section{REVESTIMENTO E CIMENTAÇÃO DE UM POÇO DE PETRÓLEO EM EVAPORITO}




\section{REVESTIMENTO E CIMENTAÇÃO DE UM POÇO DE PETRÓleO EM EVAPORITO}

A execução do revestimento e cimentação do poço de petróleo são etapas importantes que sucedem a perfuração. Após a instalação do revestimento, o espaço anular entre a coluna de revestimento e as paredes do poço é preenchido com cimento, de forma a manter o isolamento e a integridade do poço. Essas etapas devem ser executadas para garantir a segurança durante a produção do petróleo, com uma boa interação entre o revestimento, cimento e formação rochosa do poço. Assim, o poço poderá produzir sem riscos na profundidade desejada.

A modelagem numérica da perfuração do poço de petróleo em evaporito, com a implantação das etapas de revestimento e cimentação, foi realizada levando em consideração o modelo plano de deformação, situado em uma região com as características da estratigrafia típica da Bacia de Santos (Brasil).

A integridade do poço é analisada pelo comportamento das tensões nos materiais, deslocamentos e deformações antes e depois da execução do revestimento e cimentação do poço de petróleo.

\subsection{CONSIDERAÇÕES DO MODELO COM REVESTIMENTO E CIMENTAÇÃO}

O modelo simulado refere-se ao poço de petróleo situado em uma camada de sal, na profundidade de estudo de $6000 \mathrm{~m}$ abaixo do nível do mar. Trata-se da análise do modelo plano de deformação apresentado no Capítulo 3, no item 3.3, com a execução das etapas de revestimento e cimentação, a fim de observar as contribuições dessas etapas para a segurança do poço.

O modelo plano de deformação consiste num domínio 3,10 m x 3,10 m, com diâmetro do poço de $0,31 \mathrm{~m}$. A característica da estatrigrafia deste estudo de caso é similar à do capítulo anterior e está apresentada na Tabela 4-1.

A transferência do carregamento total para a seção de estudo foi realizada calculando as tensões geradas pelas três regiões: lâmina de água, "outros estratos" e camada de sal. Para a primeira região, lâmina de água, utilizou-se uma massa específica para a água do mar de 
$1019 \mathrm{~kg} / \mathrm{m}^{3}$. A região denominada "outros estratos" representa o maciço rochoso localizado acima do estrato de sal e possui massa específica média de $2307 \mathrm{~kg} / \mathrm{m}^{3}$. Para a camada de sal, constituída de halita, esse valor é de $2160 \mathrm{~kg} / \mathrm{m}^{3}$.

Tabela 4-1 - Características dos estratos para o estudo de caso até a profundidade de $6000 \mathrm{~m}$ abaixo do nível do mar.

\begin{tabular}{ccc}
\hline Tipo de material & Massa específica $\left(\mathrm{kg} / \mathrm{m}^{3}\right)$ & Profundidade $(\mathrm{m})$ \\
\hline Lâmina de água & 1019 & 0 a -2000 \\
Outros estratos & 2307 & -2000 a -4000 \\
Estrato de sal & 2160 & -4000 a -6000 \\
\hline
\end{tabular}

Fonte: Modificada de Botelho (2008).

A tensão vertical de sobrecarga, dada pela soma das tensões nas três regiões, tem um valor de 107,6 MPa. A relação entre a tensão horizontal e vertical é assumida igual para uma determinada profundidade $\left(K_{0}=1\right)$. No plano horizontal também ocorre a isotropia de tensões e, desta forma, para a profundidade de $6000 \mathrm{~m}$ abaixo do nível do $\operatorname{mar} \sigma_{1}=\sigma_{2}=107,6 \mathrm{MPa}$.

Os parâmetros elásticos e as constantes empíricas de fluência do sal adotados em todas as simulações numéricas deste trabalho são similares aos apresentados no Capítulo 3 (item 3.2) e estão resumidamente apresentados na Tabela 4-2. O comportamento de fluência do sal foi simulado utilizando o power-law model do Abaqus ${ }^{\circledR}$, na versão time-hardening.

Tabela 4-2 - Parâmetros elásticos e constantes empíricas do sal.

\begin{tabular}{cc}
\hline Parâmetros elásticos & Constantes empíricas de fluência \\
\hline $\boldsymbol{E}=\mathbf{2 , 0 4} \mathbf{E}+\mathbf{0 7} \mathbf{~ k P a}$ & $A=2,4 \mathrm{E}-17$ \\
$\mathbf{v}=\mathbf{0 , 3 6}$ & $n=3,0$ \\
- & $m=-0,7$ \\
\hline
\end{tabular}

Fonte: Modificada de Botelho (2008).

A modelagem do revestimento foi realizada como um material elasto-plástico e os parâmetros utilizados foram baseados nos valores apresentados por Bourgoyne Júnior et al. (1986). Foi considerado um revestimento do tipo API Grade C-75, com resistência de escoamento mínimo de 517,1 $\mathrm{MPa}(75000 \mathrm{psi})$, com diâmetro externo de 0,24 m 
(aproximadamente 9 5/8") e diâmetro interno de 0,21 m (aproximadamente 8,535"). Os parâmetros elasto-plásticos do revestimento são apresentados na Tabela 4-3.

Tabela 4-3 - Parâmetros elasto-plásticos do revestimento.

\begin{tabular}{cc}
\hline \multicolumn{2}{c}{ Parâmetros elasto-plásticos } \\
\hline $\mathbf{E}(\mathbf{k P a})$ & $2,0 \mathrm{E}+08$ \\
$\mathbf{v}$ & 0,30 \\
Tensão de escoamento (kPa) & $5,2 \mathrm{E}+05$ \\
\hline
\end{tabular}

Fonte: Modificada de Mackay (2011).

Após a instalação do revestimento, o espaço anular entre a coluna de revestimento e as paredes do poço é preenchido com cimento. As propriedades elásticas do cimento variam significativamente durante o período de endurecimento. O coeficiente de Poisson é adotado como sendo constante e, com isso, o valor do módulo de elasticidade final é obtido após um período de 11 dias. Os dados das propriedades elásticas do cimento foram baseados nos apresentados por Mackay (2011) e são modelados de forma a representar o ganho de rigidez ao longo do tempo (Tabela 4-4).

Tabela 4-4 - Propriedades elásticas do cimento dependentes do tempo.

\begin{tabular}{ccc}
\hline $\begin{array}{c}\text { Intervalo de Tempo } \\
(\text { dias })\end{array}$ & $\begin{array}{c}\text { Módulo de Elasticidade } \\
(\mathrm{MPa})\end{array}$ & $\begin{array}{c}\text { Coeficiente de } \\
\text { Poisson }\end{array}$ \\
\hline $\mathbf{0}-\mathbf{0 , 6}$ & $1,5 \mathrm{E}+03$ & 0,286 \\
$\mathbf{0 , 6}-\mathbf{1 , 0}$ & $2,9 \mathrm{E}+03$ & 0,286 \\
$\mathbf{1 , 0}-\mathbf{2 , 0}$ & $4,5 \mathrm{E}+03$ & 0,286 \\
$\mathbf{2 , 0}-\mathbf{3 , 0}$ & $6 \mathrm{E}+03$ & 0,286 \\
$\mathbf{3 , 0}-\mathbf{4 , 0}$ & $7,2 \mathrm{E}+03$ & 0,286 \\
$\mathbf{4 , 0}-\mathbf{5 , 0}$ & $8,2 \mathrm{E}+03$ & 0,286 \\
$\mathbf{5 , 0}-\mathbf{6 , 0}$ & $9,03 \mathrm{E}+03$ & 0,286 \\
$\mathbf{6 , 0}-\mathbf{7 , 0}$ & $9,7 \mathrm{E}+03$ & 0,286 \\
$\mathbf{7 , 0}-\mathbf{9 , 0}$ & $1,08 \mathrm{E}+04$ & 0,286 \\
$\mathbf{9 , 0}-\mathbf{1 1 , 0}$ & $1,1 \mathrm{E}+04$ & 0,286 \\
$\mathbf{>} \mathbf{1 1}$ & $1,4 \mathrm{E}+04$ & 0,286 \\
\hline
\end{tabular}

Fonte: Mackay (2011). 


\subsection{ETAPAS DA SIMULAÇÃO DA PERFURAÇÃO, REVESTIMENTO E CIMENTAÇÃO DO POÇO}

O modelo plano de deformação analisado correspondeu a um domínio de 3,10 m x $3,10 \mathrm{~m}$, localizado a uma profundidade de $6000 \mathrm{~m}$ abaixo do nível do mar, com a instalação do revestimento de diâmetro externo de $0,24 \mathrm{~m}$ e espessura de $0,015 \mathrm{~m}$. O espaço de $0,035 \mathrm{~m}$ entre o revestimento e o sal é preenchido com cimento.

Inicialmente, toda a geometria é simulada com sendo constituída por sal. Posteriormente à escavação, uma parte desta malha adquire características de revestimento e, outra parte, características de cimento. Para isto, são necessárias algumas edições no arquivo de entrada do programa (input), em que os nós e elementos que compõem o sal e que serão retornados com as características de revestimento e cimento são duplicados e nomeados diferentemente dos nós e elementos inicialmente existentes. Estes novos elementos permanecem desativados até a execução das etapas que os trazem à análise. A Figura 4-1 apresenta a geometria utilizada, em que se observam os três materiais envolvidos na análise: revestimento (marrom), cimento (cinza) e sal, com suas respectivas dimensões.

Ainda se pode observar na Figura 4-1 as condições de contorno do modelo, em que estão presentes apoios do primeiro gênero na parte inferior e lateral esquerda, de modo a impedir os deslocamentos na direção vertical e horizontal, respectivamente. Na superfície do modelo e na lateral direita podem ser observadas as tensões geostáticas atuantes, já calculadas anteriormente, sendo $\sigma_{1}=\sigma_{2}=107,6 \mathrm{MPa}$. 


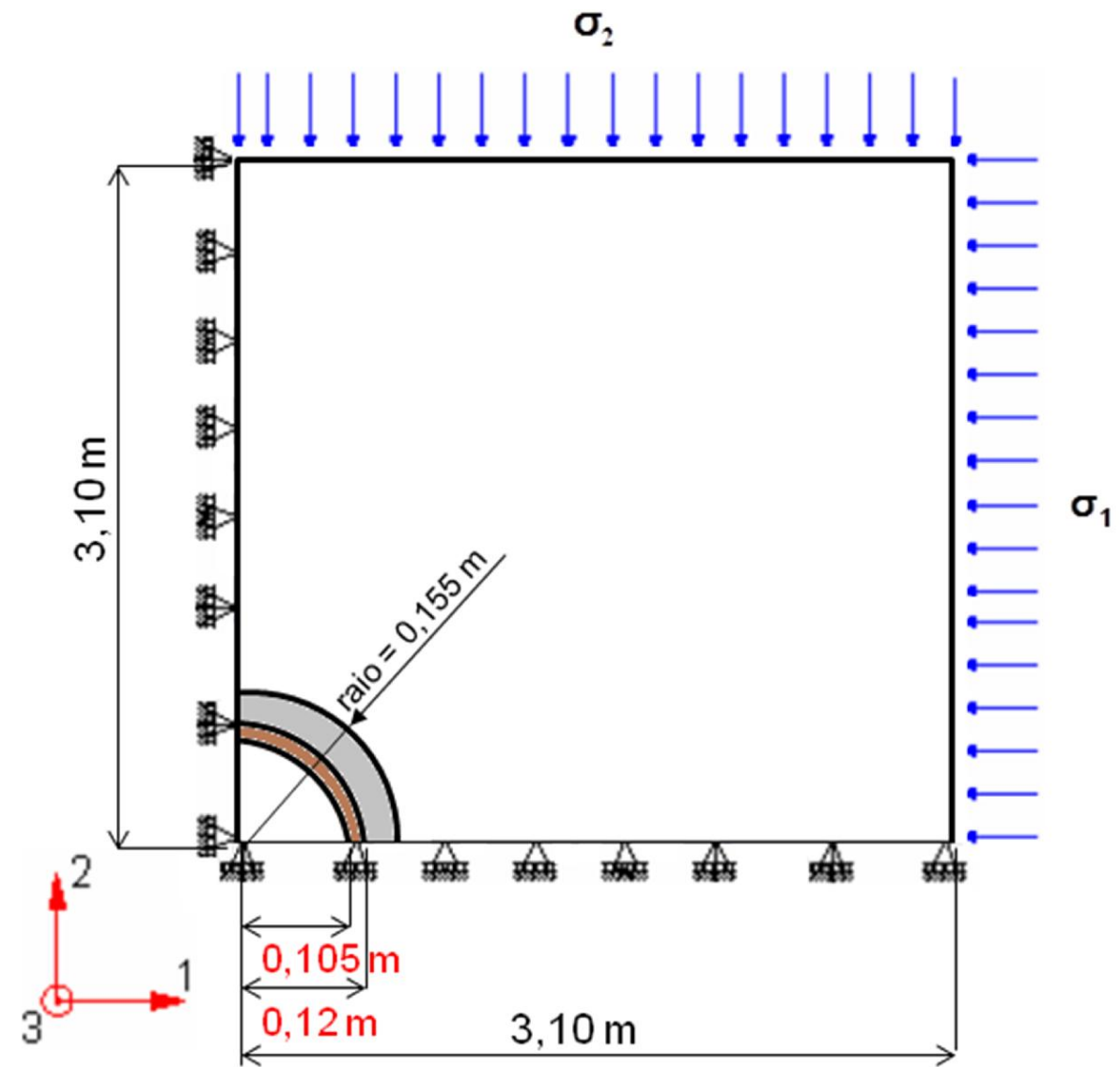

Figura 4-1 - Representação da geometria com revestimento e cimento, com as condições de contorno, sem escala.

Fonte: Modificada de Botelho (2008).

$\mathrm{Na}$ região do centro do poço até o raio interno do revestimento $(0,105 \mathrm{~m})$, foram utilizados elementos triangulares lineares (elementos de 3 nós), denominados de CPE3 no Abaqus ${ }^{\circledR}$. Para o restante da malha foram utilizados elementos quadrilaterais bilineares, elementos de 4 nós, do tipo CPE4. Um maior refinamento foi realizado na malha próximo ao local a ser escavado, pois nesta região são esperadas maiores variações de tensões, deformações e deslocamentos.

O modelo é composto por 6700 nós e 6622 elementos, dos quais 86 elementos foram do tipo CPE3 e 6736 elementos do tipo CPE4. Como os elementos triangulares são removidos na simulação da escavação do poço, todos os cálculos são feitos para os elementos quadrilaterais. A Figura 4-2a apresenta a malha de elementos finitos para a simulação da perfuração do poço e execução das etapas de revestimento e cimentação. Na Figura 4-2b pode ser visto o zoom próximo da região a ser escavada, com destaque para as malhas do revestimento e cimento. 


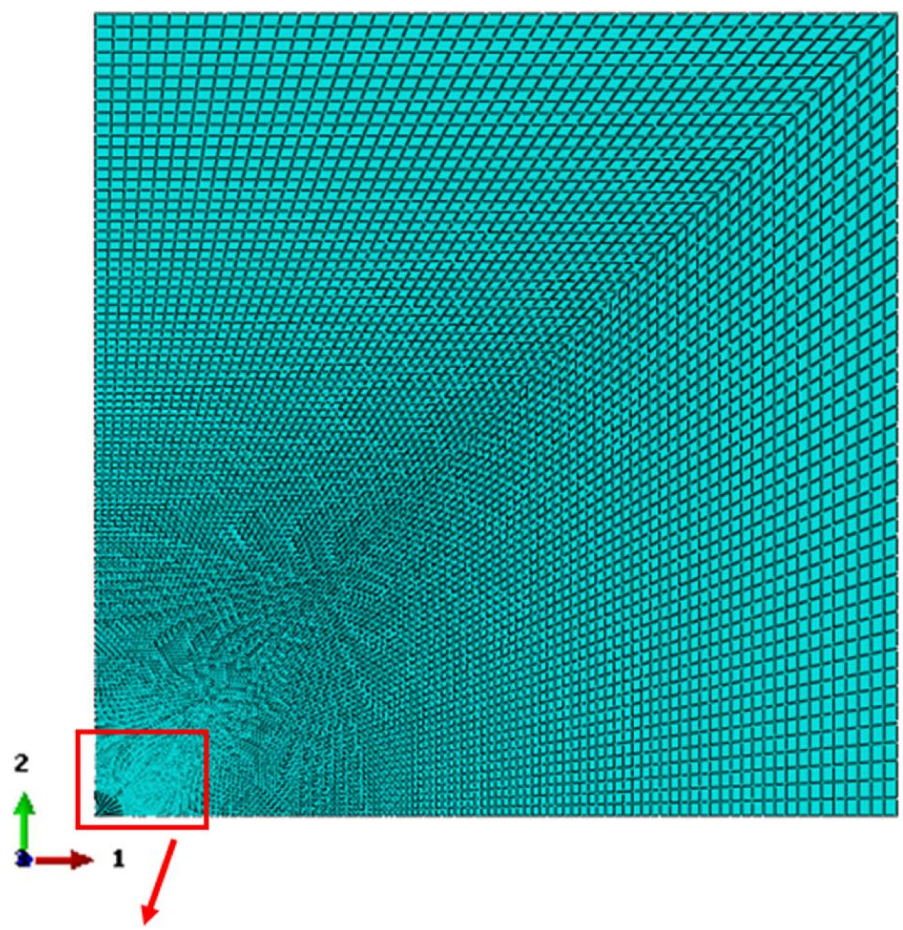

(a)

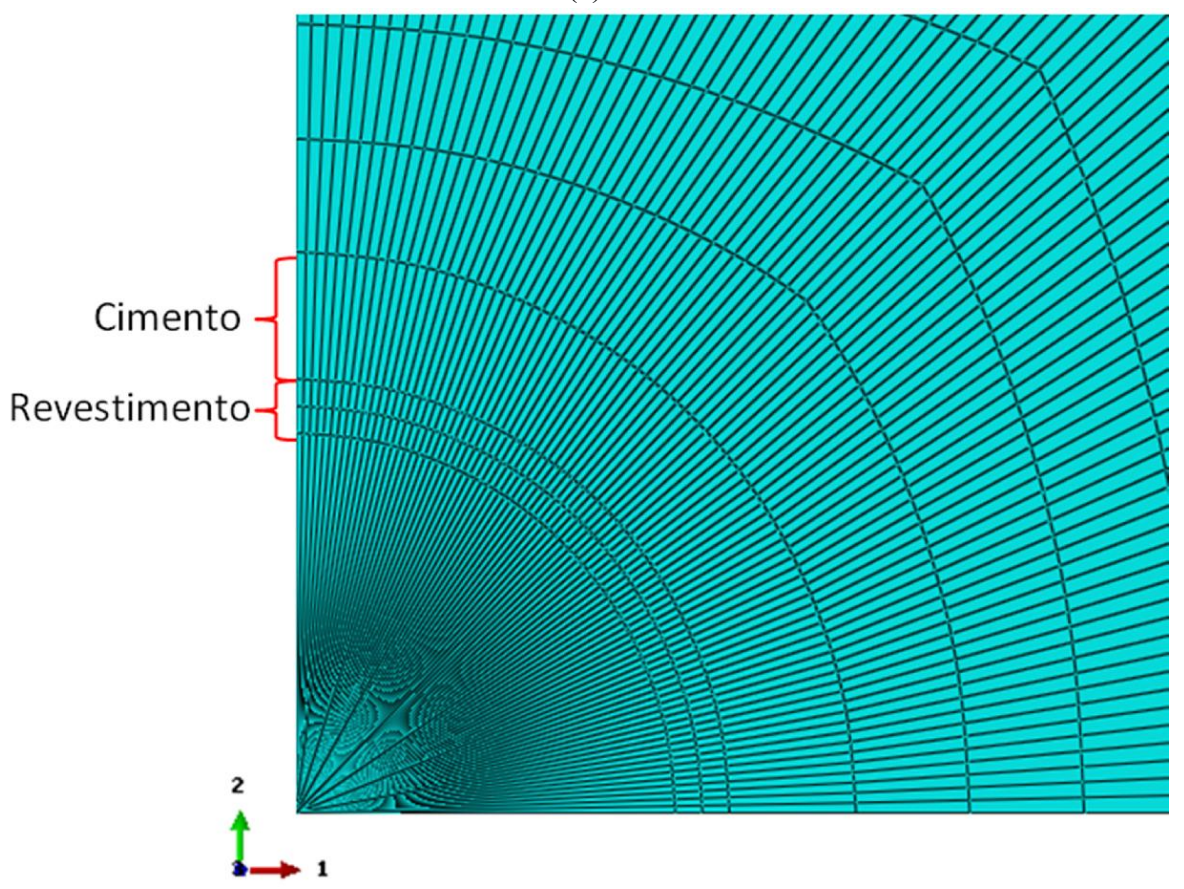

(b)

Figura 4-2 - Malha de elementos finitos utilizada na simulação numérica: (a) vista geral da malha; (b) detalhe da região próxima ao poço, com as malhas do revestimento e cimento.

A simulação foi dividida em três grandes etapas principais: perfuração do poço, instalação do revestimento e aplicação do cimento no estado líquido e, endurecimento do cimento. A perfuração do poço de petróleo consiste na retirada dos elementos que compõem o 
poço e da sua deformação por fluência do sal até a descida do revestimento. Após a instalação do revestimento é aplicada a pressão de fluido de cimento, o qual adquire seu valor final de rigidez após um período de 11 dias. Para a realização de toda análise são executadas 27 etapas de simulação, que inicia com o estado de tensões in situ e finaliza com o completo processo de endurecimento do cimento. Cada uma destas etapas será explicada mais adiante.

As análises são realizadas para um determinado peso de fluido de perfuração $\left(P_{w}\right)$. Realizam-se as mesmas análises levando em consideração outros pesos de fluido de perfuração apresentados na Tabela 4-5. Refere-se ao menor, maior e peso intermediário dos fluidos analisados no Capítulo 3.

Tabela 4-5 - Pressões do fluido de perfuração $\left(P_{w}\right)$ na profundidade de estudo de $6000 \mathrm{~m}$.

\begin{tabular}{rc}
\hline Peso do fluido de perfuração & Pressões do fluido de perfuração \\
\hline $\mathbf{9} \mathbf{p p g}=\mathbf{0 , 4 7} \mathbf{~ p s i} / \mathbf{f t}$ & $63,8 \mathrm{MPa}$ \\
$\mathbf{1 1} \mathbf{~ p p g}=\mathbf{0 , 5 7} \mathbf{~ p s i} / \mathbf{f t}$ & $77,4 \mathrm{MPa}$ \\
$\mathbf{1 3} \mathbf{~ p p g}=\mathbf{0 , 6 7} \mathbf{~ p s i} / \mathbf{f t}$ & $90,9 \mathrm{MPa}$ \\
\hline
\end{tabular}

Fonte: Modificada de Botelho (2008).

\subsubsection{Perfuração do poço}

A simulação da perfuração consiste basicamente na desativação dos elementos do poço, sendo inicialmente toda a geometria constituída de halita (Figura 4-3). A análise da perfuração do poço de petróleo em evaporito é realizada com a execução das três primeiras etapas de simulação.

A primeira etapa refere-se ao uso da função geostática do Abaqus ${ }^{\circledR}$, com o carregamento das tensões no modelo, procurando conferir que o estado de tensões geostáticas esteja em equilíbrio com o carregamento aplicado no contorno do modelo. Na segunda etapa, a qual corresponde à escavação do poço, foi simulada a resposta elástica devida à desativação da malha do poço e à introdução das tensões provocadas pelo fluido de perfuração na parede do poço $\left(P_{w}\right)$. A fluência do sal antes da descida do revestimento foi simulada para um tempo máximo de 30 dias, correspondendo à terceira etapa da simulação (Figura 4-4). 


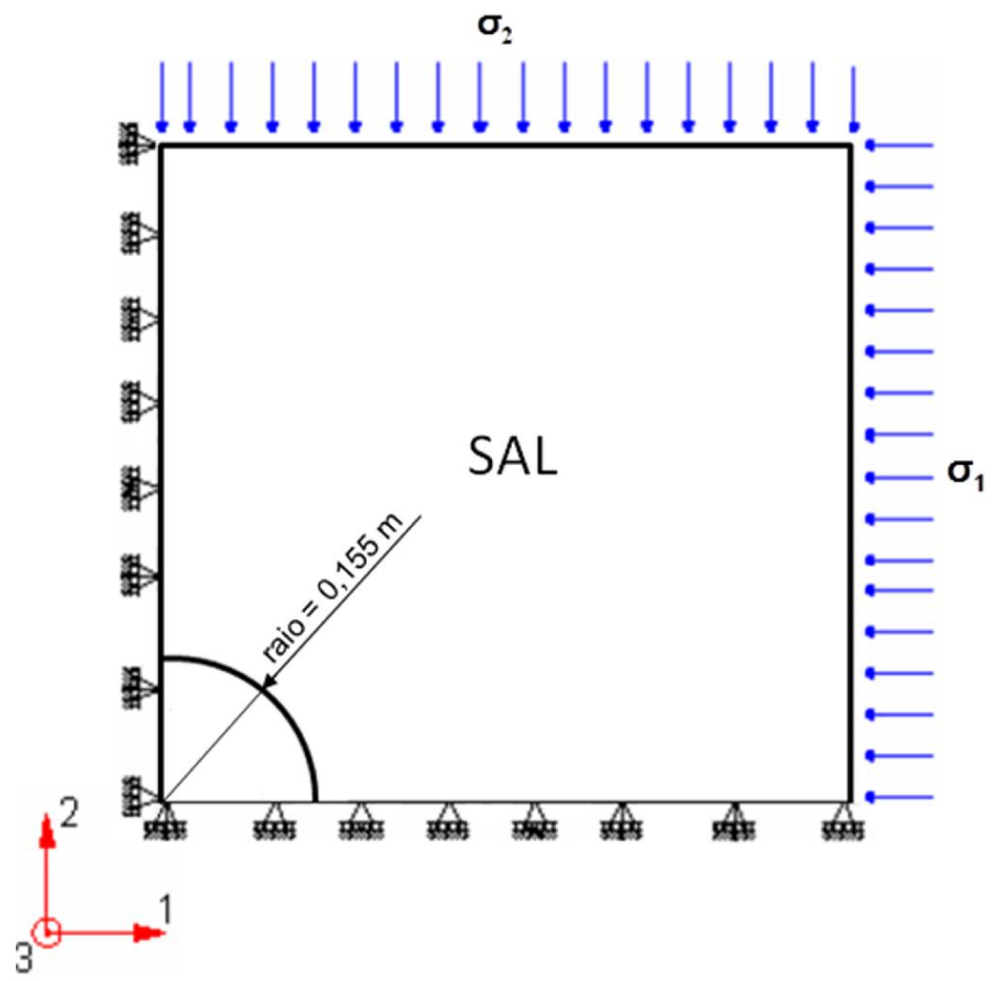

Figura 4-3 - Etapa geostática, sem escala.

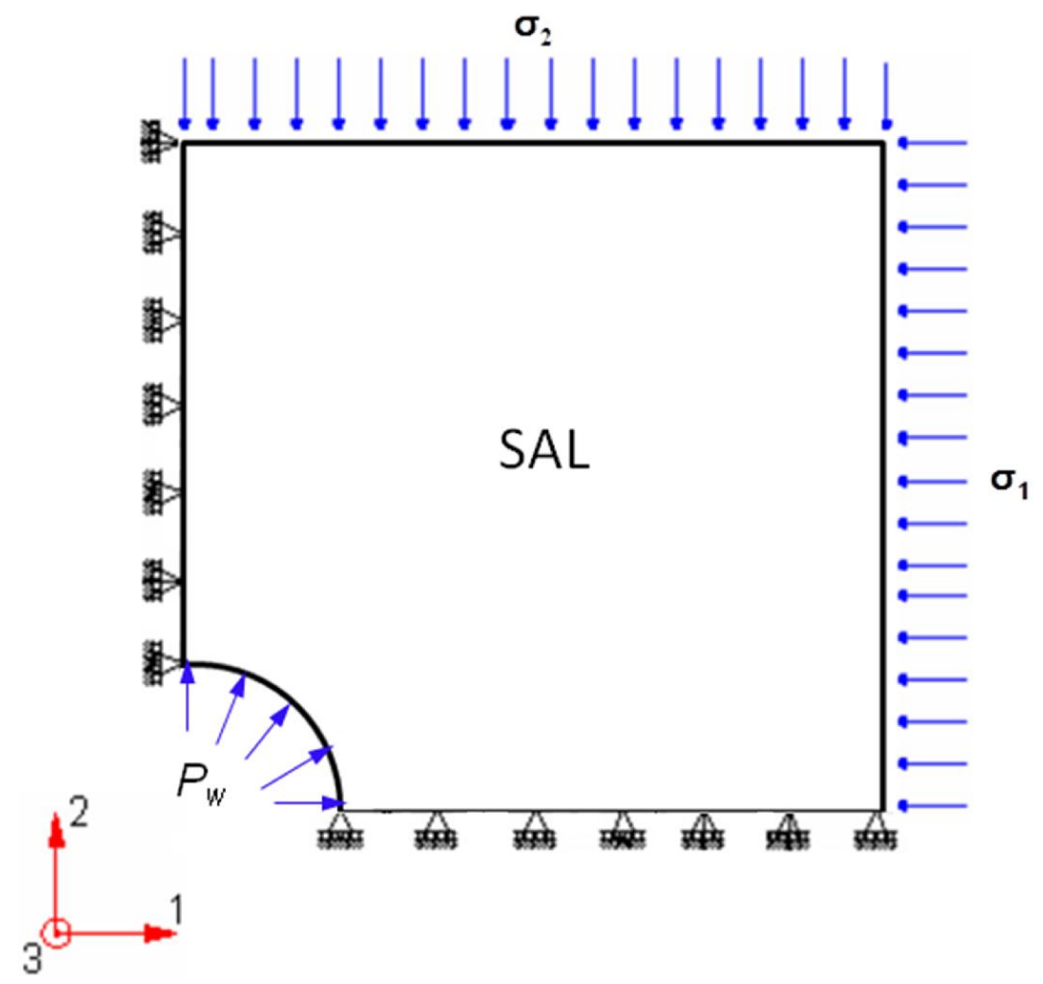

Figura 4-4 - Etapa elástica e fluência do sal, sem escala. 


\subsubsection{Revestimento e aplicação do cimento no estado líquido}

Após a simulação da escavação do poço, uma parte desta malha retorna com características de revestimento. Assim, na quarta etapa, a malha que representa o revestimento é ativada e aparece inicialmente recebendo a pressão do fluido de perfuração. Este fluido atua na parede do poço, nas partes externa e interna do revestimento, como representado na Figura 4-5. Ainda se percebe que os nós do lado esquerdo e na parte inferior do revestimento são impedidos de se movimentar nas direções horizontal e vertical, respectivamente.

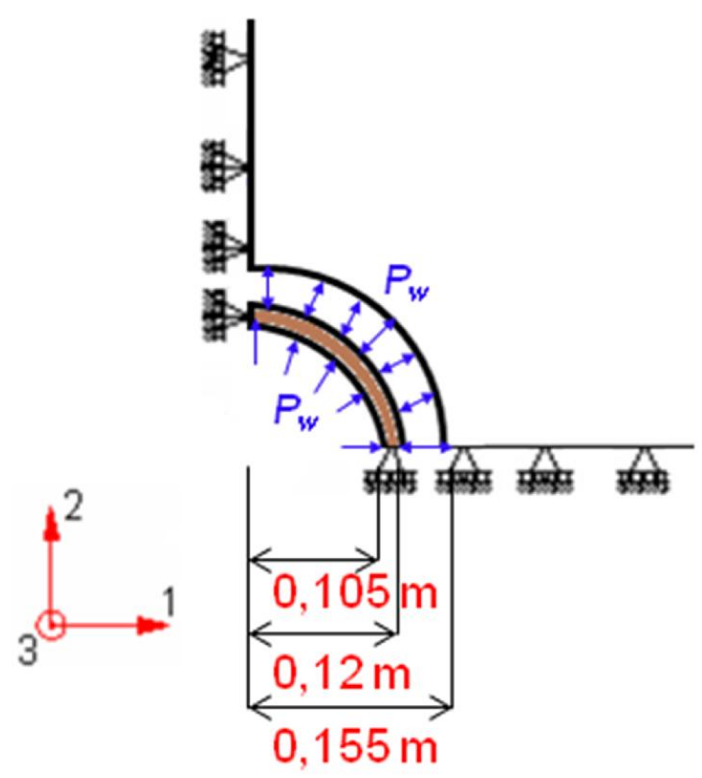

Figura 4-5 - Instalação do revestimento e pressão do fluido de perfuração $\left(P_{w}\right)$ na parede do poço, nas partes externa e interna do revestimento, sem escala.

A pressão do fluido de cimento é calculada em função do valor encontrado na literatura (GRAY; PODNOS; BECKER, 2007), 15,8 ppg (16173,2 psi), que equivale a 111,5 MPa $\left(P_{w c}\right)$ para a profundidade de estudo de $6000 \mathrm{~m}(19685 \mathrm{ft})$. Esta pressão de fluido é aplicada na quinta etapa de simulação e atua na parede do poço, nas partes externa e interna do revestimento, como representado na Figura 4-6, simulando a aplicação do cimento no estado líquido. 


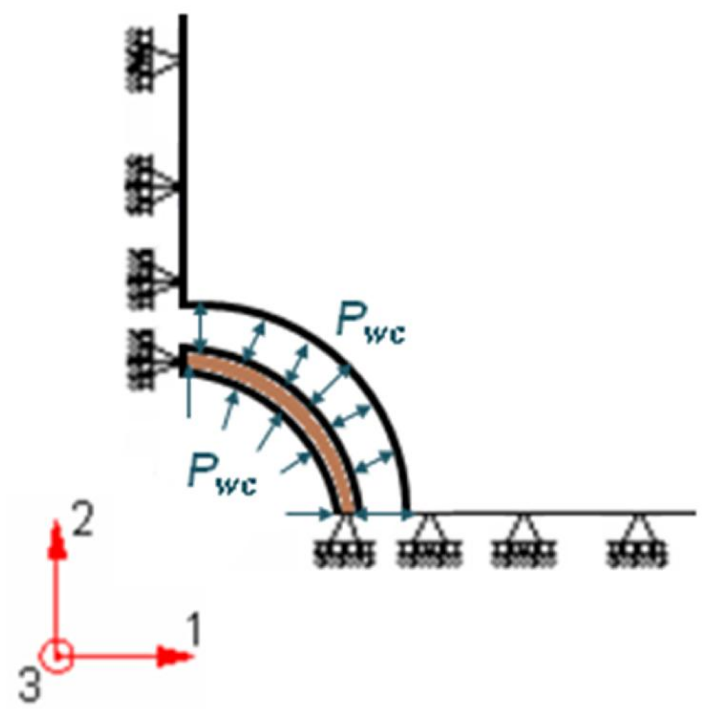

Figura 4-6 - Revestimento com aplicação da pressão do fluido de cimento $\left(P_{w c}\right)$ na parede do poço, nas partes externa e interna do revestimento, sem escala.

Após essa etapa, aplica-se a pressão do fluido de perfuração no interior do revestimento, a fim de limpar essa região e conduzir o fluido de cimento para o espaço anular entre a parede do poço e o revestimento. Assim, na sexta etapa, a pressão do fluido de perfuração atua na parte interna do revestimento, enquanto que a pressão do fluido do cimento atua no espaço anular (Figura 4-7).

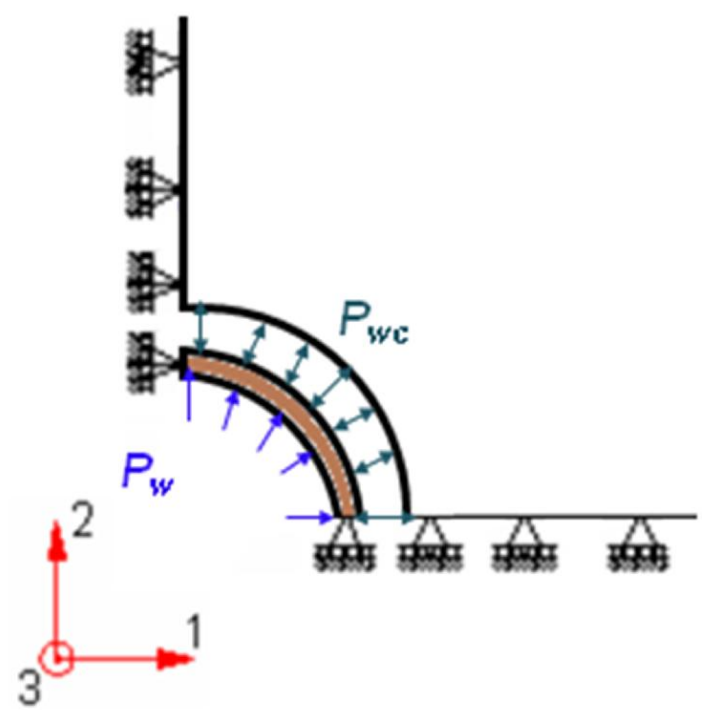

Figura 4-7 - Revestimento com aplicação da pressão do fluido de cimento $\left(P_{w c}\right)$ na parede do poço e na parte externa do revestimento. Aplicação da pressão do fluido de perfuração $\left(P_{w}\right)$ na parte interna do revestimento, sem escala. 


\subsubsection{Endurecimento do cimento}

As etapas seguintes consistem no processo de endurecimento do cimento, com consequente ganho de rigidez. Na sétima etapa a malha do cimento é ativada e inserida com estado de tensão inicial do cimento correspondente a 111,5 MPa. É interessante destacar que antes da ativação da malha do cimento, ocorreu uma deformação na malha do poço pelo efeito da fluência do sal (etapa 3). Desta forma, a malha do cimento ocupa novas posições, sendo necessário adaptar esta malha às novas posições da malha deformada. Para isto, é necessário inserir um comando no Abaqus que conecte os nós que constituem a malha do cimento com as novas posições encontradas, de modo que não existam separações entre as superfícies da fronteira revestimento-cimento e cimento-sal.

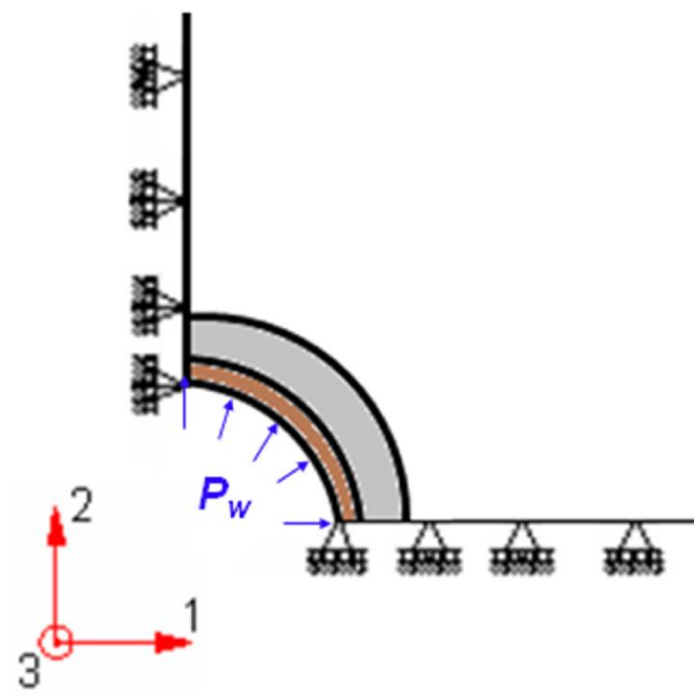

Figura 4-8 - Ativação da malha de cimento, com a continuidade da aplicação da pressão do fluido de perfuração $\left(P_{w}\right)$ na parte interna do revestimento, sem escala.

Da sétima à vigésima sexta etapa, simula-se o endurecimento do cimento em um período de tempo, conforme mostrado na Tabela 4-4. Para cada período de tempo necessário para o ganho de rigidez do cimento, ocorre a fluência do sal. Assim, tem-se a divisão deste processo de endurecimento em 10 pares de etapas. Cada par corresponde ao ganho de rigidez, com a resposta elástica e fluência do sal. Na última etapa, vigésima sétima, o cimento atinge seu valor final de rigidez. A pressão do fluido de perfuração é continuamente aplicada na parte interna do revestimento durante todo esse processo.

Os parâmetros elásticos do cimento variam a cada par de passos da simulação, após o cimento ser adicionado ao restante da malha. A análise foi realizada de forma que as tensões e 
as deformações decorrentes de cada par no processo de endurecimento do cimento (resposta elástica e fluência do sal) fossem as iniciais do próximo par de etapas. O deslocamento decorrente do ganho de rigidez do cimento se dá devido à diferença entre as tensões provocadas pelo cimento nessa região e pela pressão constante do fluido de perfuração aplicado na parte interna do revestimento.

Quando, numa estrutura, a tensão e o módulo de elasticidade variam com o tempo, o acréscimo de deformação em um determinado instante é relacionado ao acréscimo de tensão no mesmo instante e à matriz de elasticidade calculada com parâmetros válidos também para o mesmo instante $t$ :

$$
\{d \sigma\}=[D(t)](d \varepsilon)
$$

Tomando-se por simplicidade o caso unidimensional, ou seja, de uma barra cujo módulo de elasticidade varia com o tempo, sujeita a uma tensão também variável com o tempo, a Equação 4-1 pode ser escrita como:

$$
d \varepsilon=\frac{1}{E(t)} d \sigma
$$

As funções $\sigma(t)$ e $E(t)$ podem ter comportamentos como os mostrados na Figura 4-9 e Figura 4-10, respectivamente.

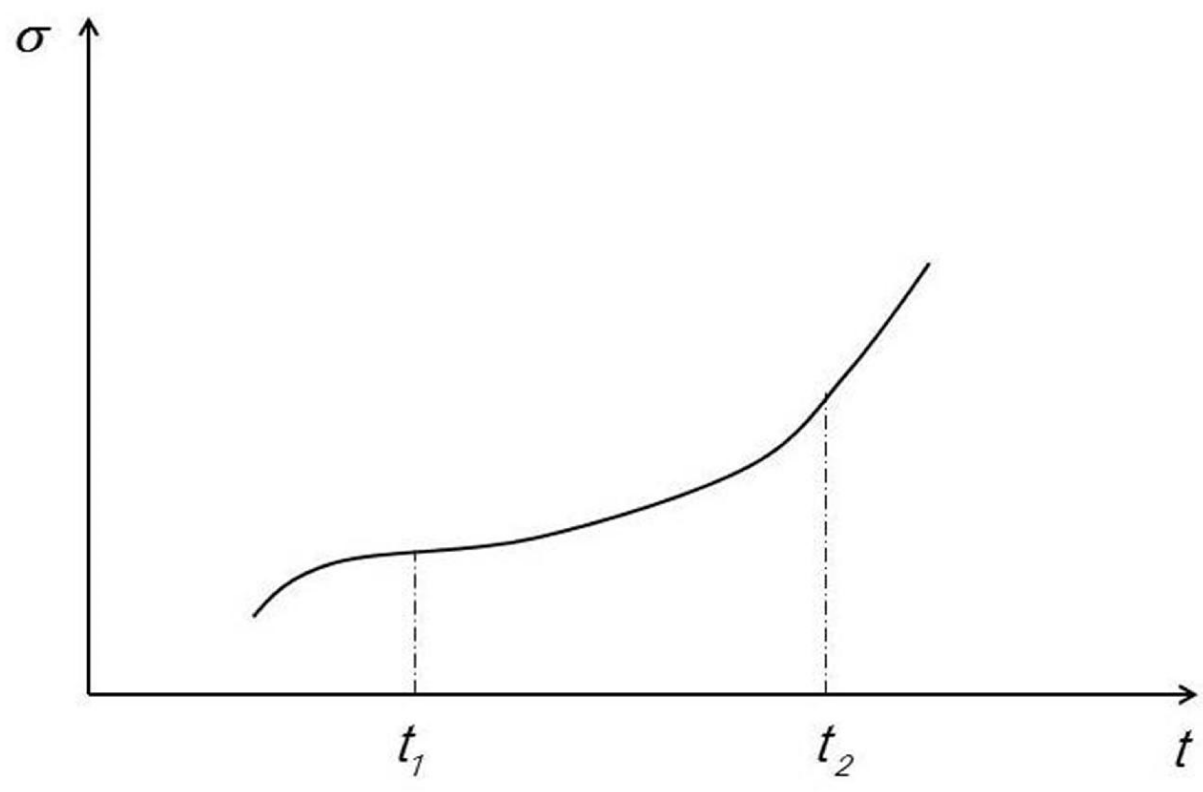

Figura 4-9 - Variação da tensão com o tempo. 


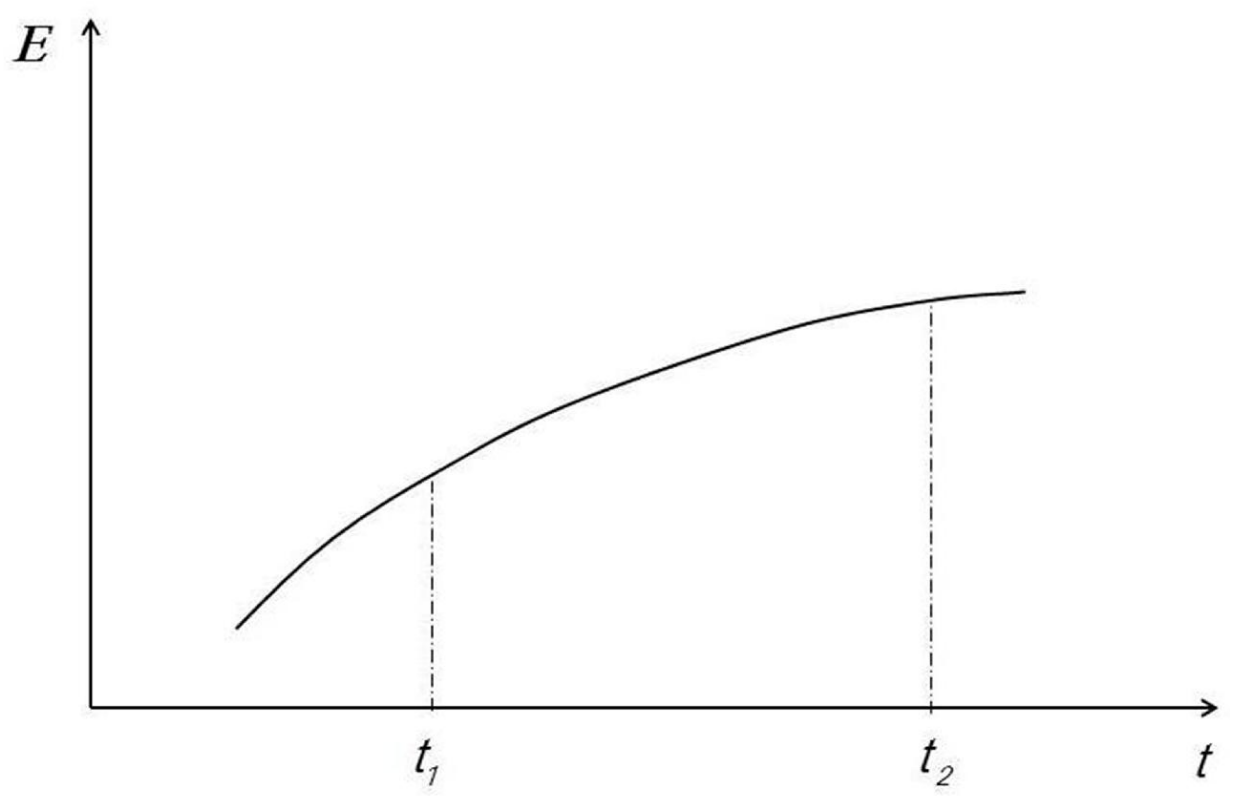

Figura 4-10 - Variação do módulo de elasticidade com o tempo.

A deformação $\varepsilon_{t_{1}, t_{2}}$ acumulada no intervalo de tempo entre $t_{1}$ e $t_{2}$ pode ser obtida por:

$$
\varepsilon_{t_{1}, t_{2}}=\int_{t_{1}}^{t_{2}} \frac{1}{E(t)} \cdot \frac{d \sigma(t)}{d t} d t
$$

Das Equações 4-2 e 4-3, constata-se que não haverá acréscimo de deformação quando não houver acréscimo de tensão, mesmo que o módulo de elasticidade varie.

Quando o procedimento é discretizado em fases distintas de cálculo, as tensões iniciais na fase $i$ são as tensões calculadas na fase anterior $i-11$ (CELESTINO; TAGLIATELLA; CUSTÓDIO, 1974).

\subsection{RESULTADOS E DISCUSSÕES DA PERFURAÇÃO, REVESTIMENTO E CIMENTAÇÃO DO POÇO DE PETRÓLEO EM EVAPORITO}

As análises de deslocamento, deformação e tensão são realizadas após a etapa de fluência decorrente da perfuração do poço e após a instalação do revestimento com o processo de endurecimento do cimento. Os resultados para estas análises são obtidos em um nó na parede do poço que está apresentado em destaque na Figura 4-11. 


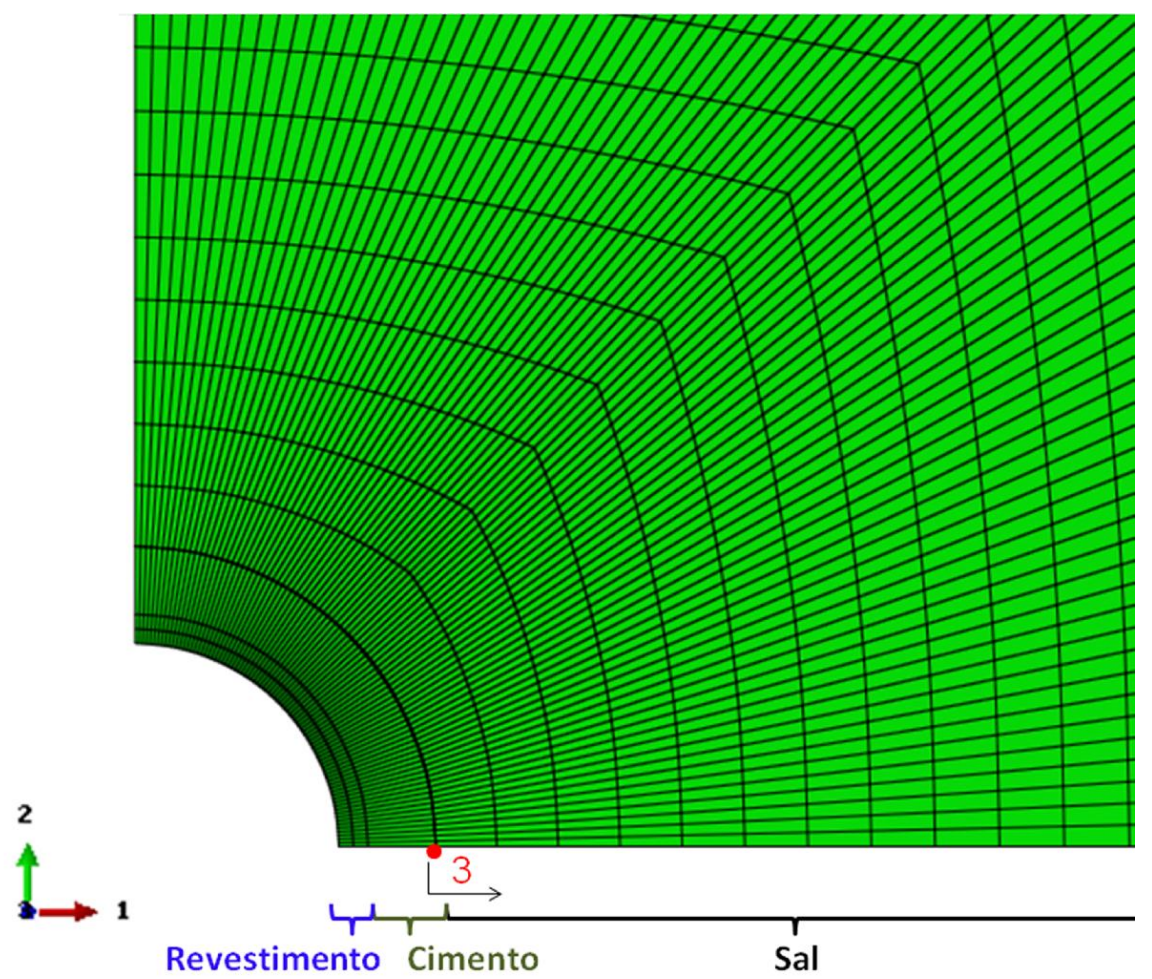

Figura 4-11 - Representação do nó de análise na parede do poço.

\subsubsection{Deslocamentos}

As análises dos deslocamentos radiais foram realizadas considerando os dados do nó na parede do poço (Figura 4-11). Inicialmente, verificam-se os deslocamentos radiais quando utilizado o peso do fluido de perfuração de 9 ppg em um período de fluência de 30 dias após a escavação do poço (etapa 3), estando representados na Figura 4-12. 


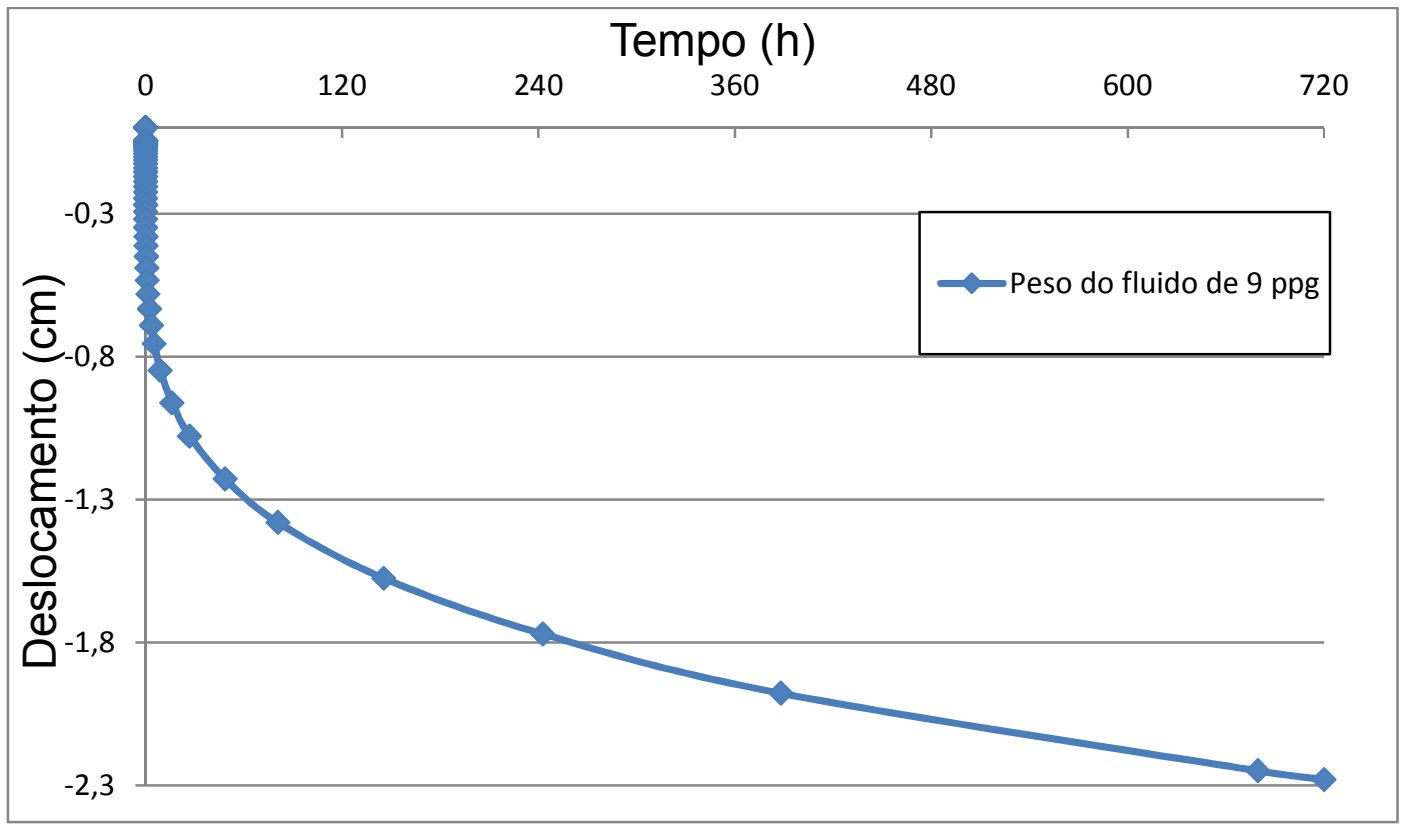

Figura 4-12 - Deslocamento radial na parede do poço em um período de um mês de fluência após a escavação, para um fluido de perfuração com peso de 9 ppg - etapa 3.

A Figura 4-12 mostra que após um período de um mês de fluência com a utilização de um fluido de perfuração com peso de 9 ppg, ocorreu um fechamento no poço de $2,28 \mathrm{~cm}$. Percebe-se que em um dia após a perfuração, o poço sofreu cerca de $47 \%$ do fechamento total, no período de 30 dias, como mostrado na Figura 4-13.

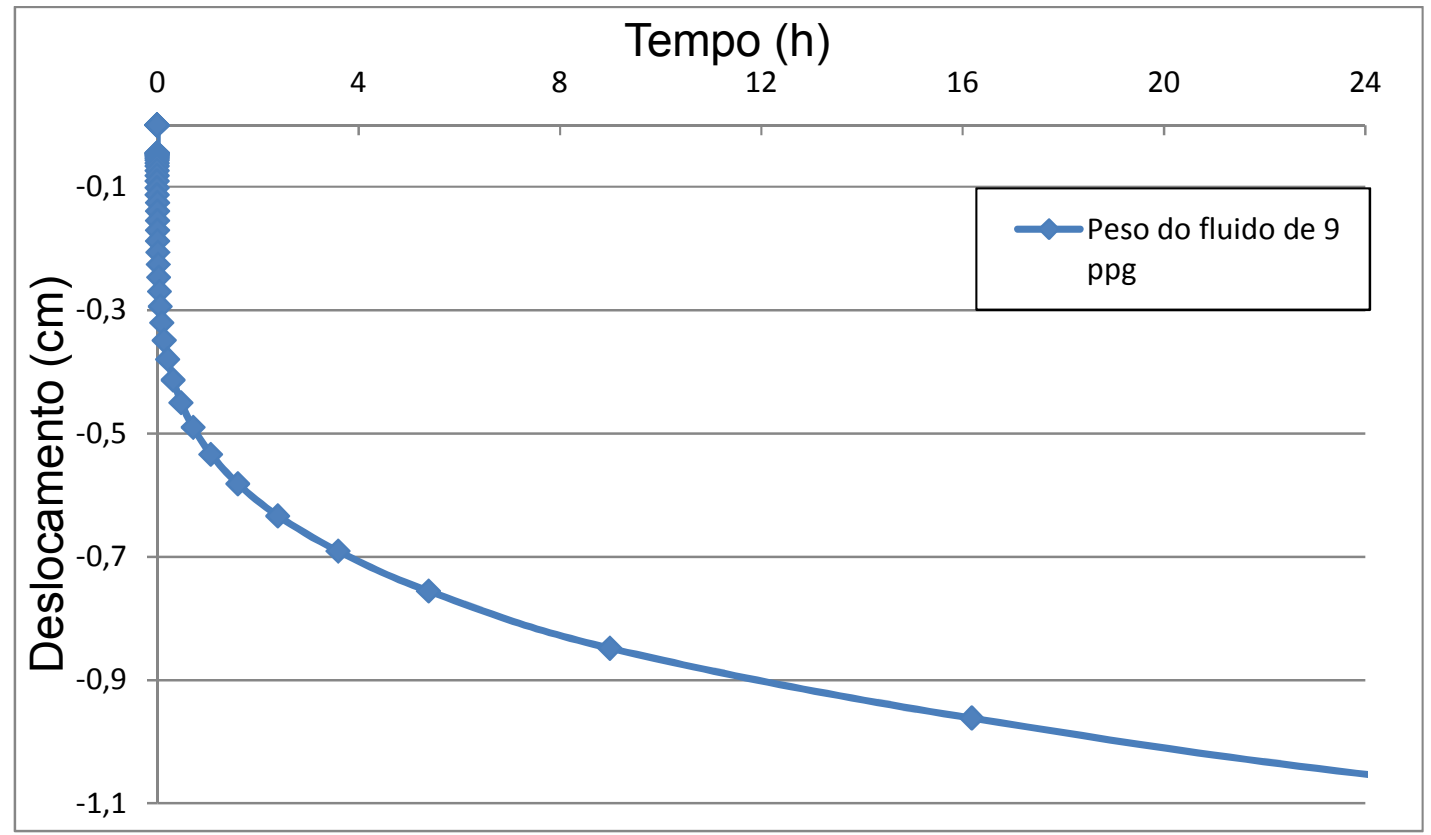

Figura 4-13 - Deslocamento radial na parede do poço em um período de um dia de fluência após a escavação, para um fluido de perfuração com peso de 9 ppg - etapa 3 . 
Após a instalação do revestimento e aplicação do cimento no estado líquido, deu-se início ao processo de endurecimento do cimento. Antes, porém, fez-se a verificação do comportamento do estrato salino aplicando-se diferentes condições de rigidez: nula, infinita e intermediária.

A Figura 4-14 apresenta três curvas para a análise do comportamento do poço quando utilizado cimento no estado líquido $\left(P_{w c}=111,5 \mathrm{MPa}\right)$, cimento com rigidez infinita $(E=1,5 \mathrm{E} 08+\mathrm{MPa})$ e com um valor de rigidez intermediário $(E=1,5 \mathrm{E}+03 \mathrm{MPa}) . \mathrm{O}$ gráfico mostra o deslocamento radial na parede do poço após a perfuração, fluência do sal e endurecimento do cimento em um período de 11 dias nos casos de rigidez infinita e intermediária. Na aplicação do cimento em estado líquido, o mesmo foi aplicado na parte externa do revestimento e na parede do poço. Nos três casos, na parte interna do revestimento, o fluido de perfuração é continuamente aplicado com uma pressão de 63,8 MPa.

O eixo das abscissas da Figura 4-14 representa o tempo após a fluência do sal decorrente da escavação do poço até os 11 dias de análise da aplicação e endurecimento do cimento. O deslocamento decorrente da fluência do sal foi de $2,28 \mathrm{~cm}$ no sentido do fechamento do poço. Com a aplicação da pressão do fluido de cimento na parte externa do revestimento e na parede do poço, o deslocamento na parede do poço passou a ser de 2,24 cm. Ao utilizar um material com rigidez infinita preenchendo o espaço anular entre a coluna de revestimento e as paredes do poço, percebe-se que as paredes do poço não mais se deslocam, enquanto que no caso da aplicação contínua da pressão do fluido de cimento esse deslocamento é máximo para aquele tempo de análise, sendo de 2,20 cm após 11 dias. A curva com rigidez intermediária provoca um deslocamento na parede do poço entre os dois valores obtidos quando se utiliza a análise com rigidez máxima e nula. 


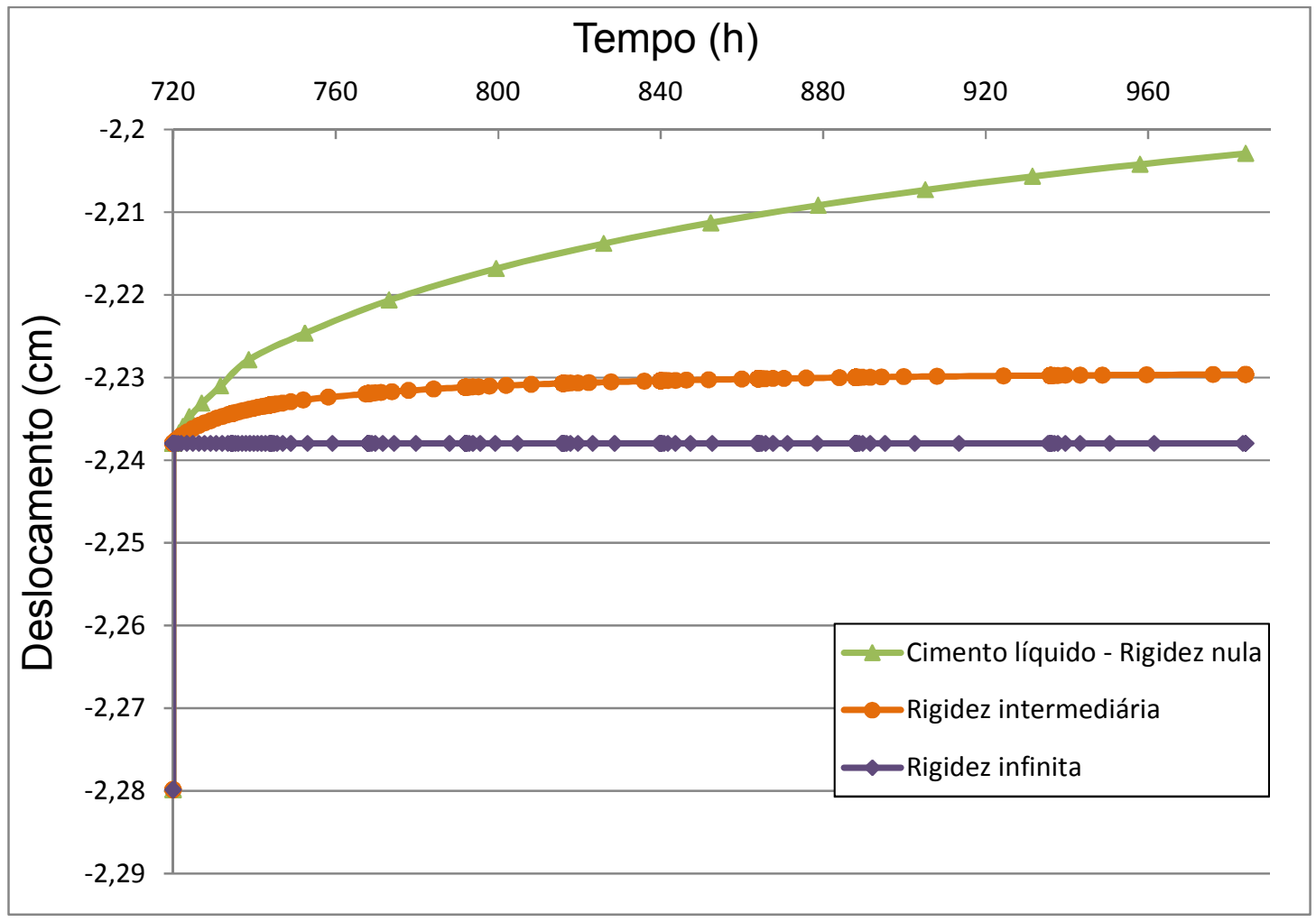

Figura 4-14 - Deslocamento radial na parede do poço em um período de 11 dias com o cimento líquido, cimento de rigidez infinita e rigidez intermediária, para um fluido de perfuração com peso de 9 ppg.

O aumento progressivo da rigidez do cimento durante esse processo ocorre no decorrer das 21 etapas da simulação (etapa 7- etapa 27), desde a ativação da malha do cimento, e são intercaladas em uma simulação elástica e outra simulação de fluência do sal. Ainda, o fluido de perfuração aplicado na parte interna do revestimento atua durante todo o processo de endurecimento do cimento. Este processo ocorre em um período de tempo, conforme mostrado na Tabela 4-4. Na última etapa, vigésima sétima, o cimento atinge seu valor final de rigidez.

Ao observar os deslocamentos em um nó da fronteira cimento-sal (nó 3) por meio da curva em vermelho apresentada na Figura 4-15, percebe-se que com o aumento do módulo de elasticidade o cimento apresenta uma maior rigidez e, com isso faz com que ocorra uma diminuição na evolução dos deslocamentos na parede do poço no sentido do fechamento do mesmo. Ao comparar a curva em vermelho com a curva em verde, em que foi utilizado ao longo dos 11 dias de análise cimento líquido na parte externa do revestimento e na parede do poço, percebe-se que com a evolução da rigidez do cimento esse deslocamento é inferior ao aplicar apenas o cimento em sua fase líquida. Tal fato está condizente ao explicado anteriormente na Figura 4-14. Quando a análise é realizada sem a correta consideração das 
tensões iniciais ao se passar de uma fase a outra no ganho de rigidez do cimento, curva em azul, o deslocamento na parede do poço é superior ao deslocamento quando a rigidez é nula (cimento em sua fase líquida). Isto ocorre porque em cada fase acrescenta-se o deslocamento elástico decorrente da aplicação da tensão sobre o anel de cimento. Não é correto este procedimento porque não existe acréscimo de tensão quando aumenta o módulo de elasticidade do anel de cimento.

Para que se obtenha os deslocamentos com a correta consideração das tensões, algumas modificações foram feitas no arquivo de entrada do programa (input), de modo que a cada nova fase em que os parâmetros elásticos do cimento variam, as tensões e deformações inicias desta nova etapa correspondem as finais decorrentes das etapas anteriores. Sem essa consideração no input, obtém-se a situação explicada para a curva em azul apresentada na Figura 4-15.

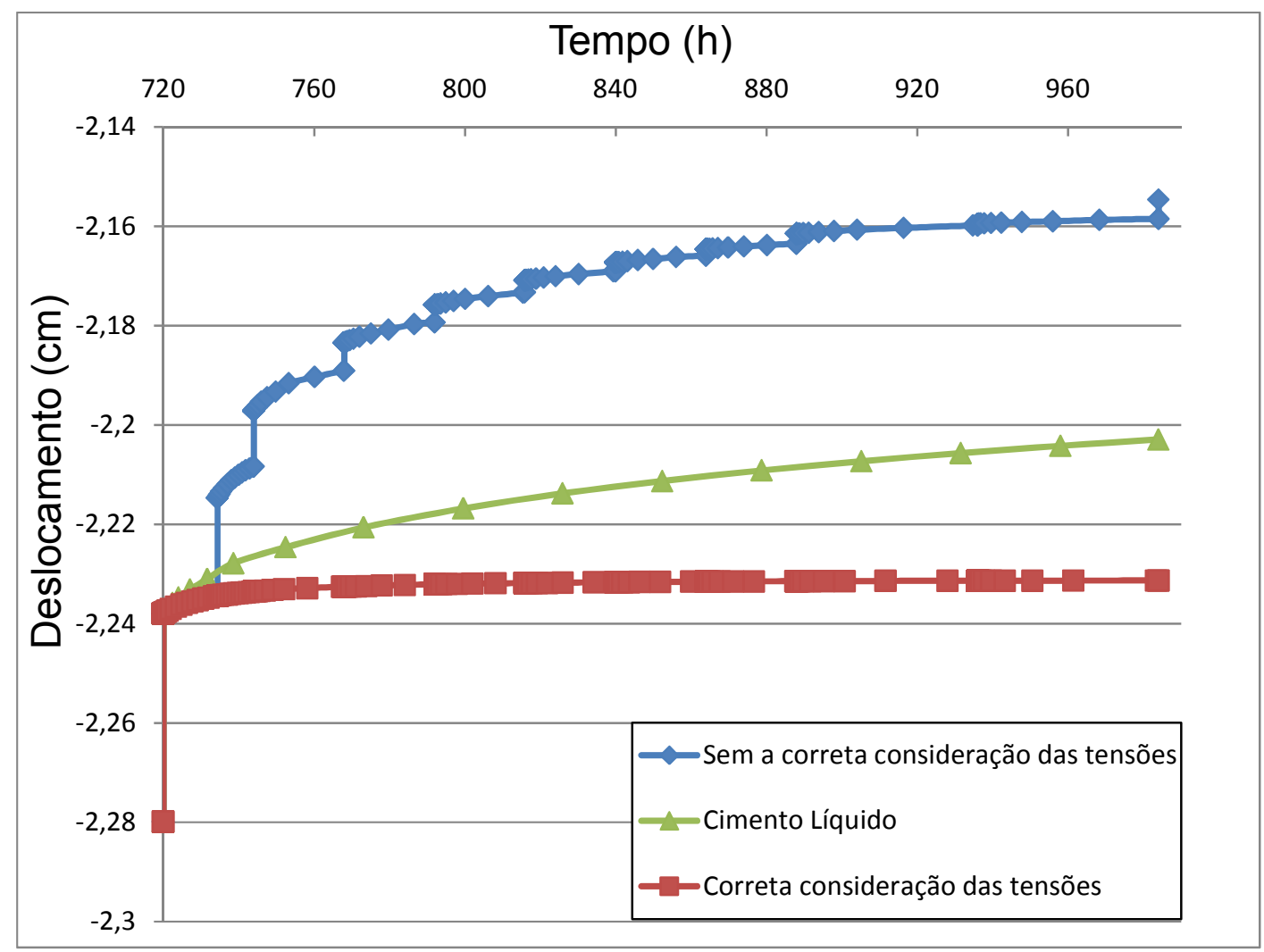

Figura 4-15 - Deslocamento radial na parede do poço em um período de 11 dias de endurecimento do cimento com aumento da rigidez no tempo, com e sem a correta consideração das tensões (seguindo a Tabela 4-4). Análise da aplicação do cimento na fase líquida. Fluido de perfuração com peso de 9 ppg. 
Analisando o gráfico da Figura 4-15 em que é utilizada a correta consideração das tensões e um fluido de perfuração com peso de 9 ppg $(63,8 \mathrm{MPa})$, percebe-se que o deslocamento na parede do poço decorrente da fluência do sal após a escavação foi de $2,28 \mathrm{~cm}$ no sentido do fechamento do poço, passa a ter um valor de $2,23 \mathrm{~cm}$ após o ganho total de rigidez do cimento. Ou seja, com a utilização do revestimento e sua posterior cimentação, pode-se conter o deslocamento por fluência do sal, evitando a continuidade do fechamento do poço.

Ao verificar os deslocamentos na parede do poço para os fluidos de perfuração com maiores pesos, apresentados na Tabela 4-5, percebe-se que o mesmo fato é evidenciado em relação ao deslocamento por fluência no sentido do fechamento do poço ser contido. A Figura 4-16 apresenta o deslocamento em um nó na parede do poço (nó 3) para o peso do fluido de perfuração de 11 ppg. O deslocamento provocado por um período de um mês de fluência após a escavação do poço, para este fluido utilizado, é de aproximadamente $0,94 \mathrm{~cm}$. Após o processo de endurecimento do cimento em 11 dias, esse deslocamento foi de $0,90 \mathrm{~cm}$.

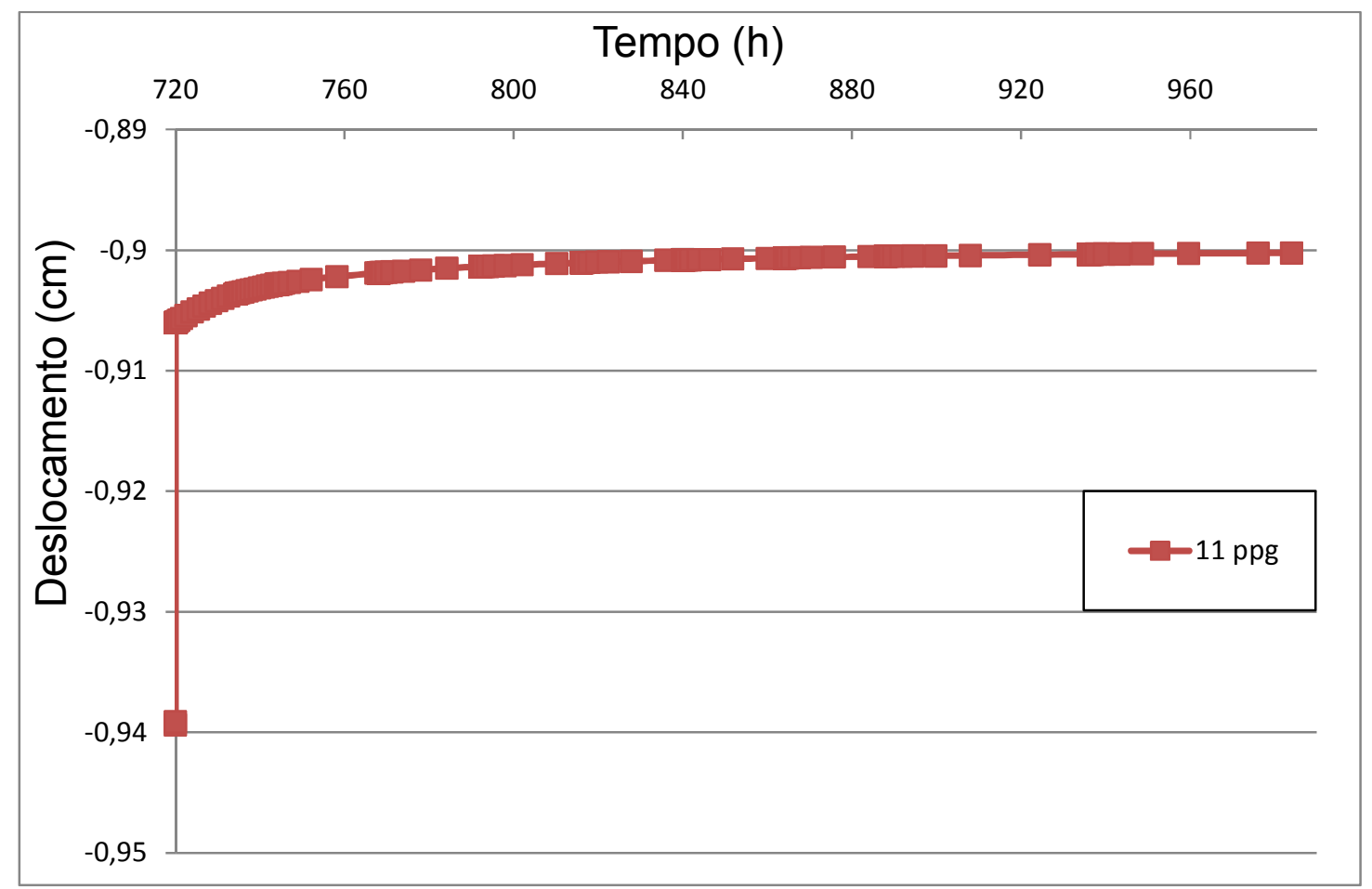

Figura 4-16 - Deslocamento radial na parede do poço em um período de 11 dias de endurecimento do cimento com aumento da rigidez no tempo, para um fluido de perfuração com peso de 11 ppg (seguindo a Tabela 4-4). 
A Figura 4-17, ilustra a situação em que é utilizado o fluido de perfuração de maior peso, $13 \mathrm{ppg}$, obtendo-se um fechamento do poço de $0,24 \mathrm{~cm}$ em um período de 30 dias de fluência após a escavação e, com o aumento da rigidez do cimento esse deslocamento passa a ser de $0,22 \mathrm{~cm}$.

Como já bastante discutido no Capítulo 3, é importante a escolha do fluido de perfuração a ser aplicado durante a perfuração de poços de petróleo, para que se tenha um menor fechamento do poço, evitando problemas durante a perfuração ou, até mesmo, em sua produção. Percebe-se ainda que quando aplicado um maior peso de fluido de perfuração, o fechamento do poço é menor, e este fechamento diminui ainda mais com o ganho de rigidez do cimento, evidenciando a importância da execução das etapas de revestimento e cimentação para manter a integridade do poço e permitir, posteriormente, a sua produção de forma segura.

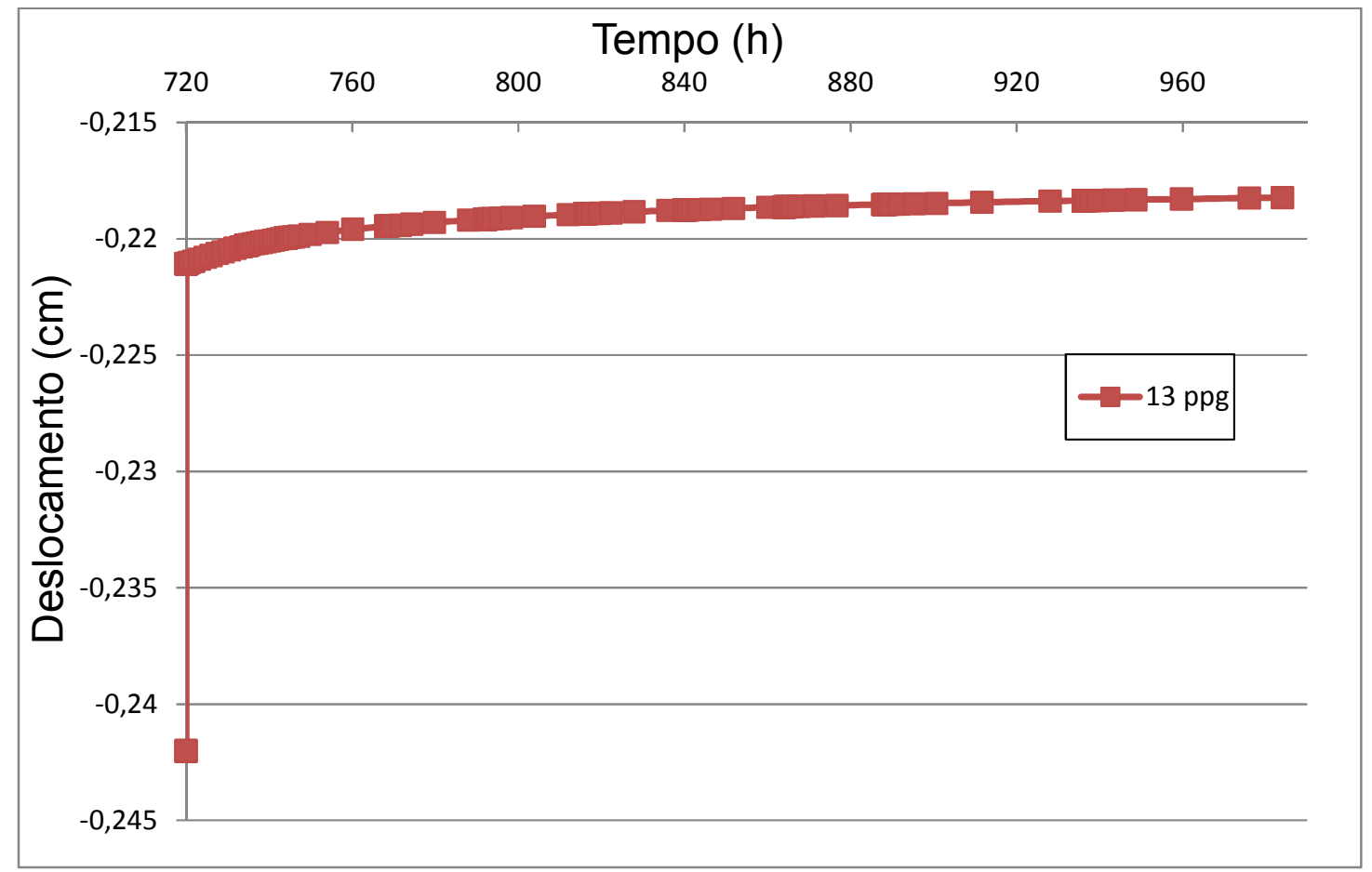

Figura 4-17 - Deslocamento radial na parede do poço em um período de 11 dias de endurecimento do cimento com aumento da rigidez no tempo, para um fluido de perfuração com peso de 13 ppg (seguindo a Tabela 4-4).

A Figura 4-18 apresenta os deslocamentos no sentido do eixo 1, por meio de uma escala de cores no Abaqus ${ }^{\circledR}$, para o modelo plano de deformação com peso do fluido de perfuração de 13 ppg, em um período de um mês de fluência após a escavação do poço. A Figura 4-19 apresenta os deslocamentos após a instalação do revestimento e aplicação do fluido de cimento em estado líquido. Os deslocamentos decorrentes do processo de 
endurecimento do cimento estão representados na Figura 4-20.

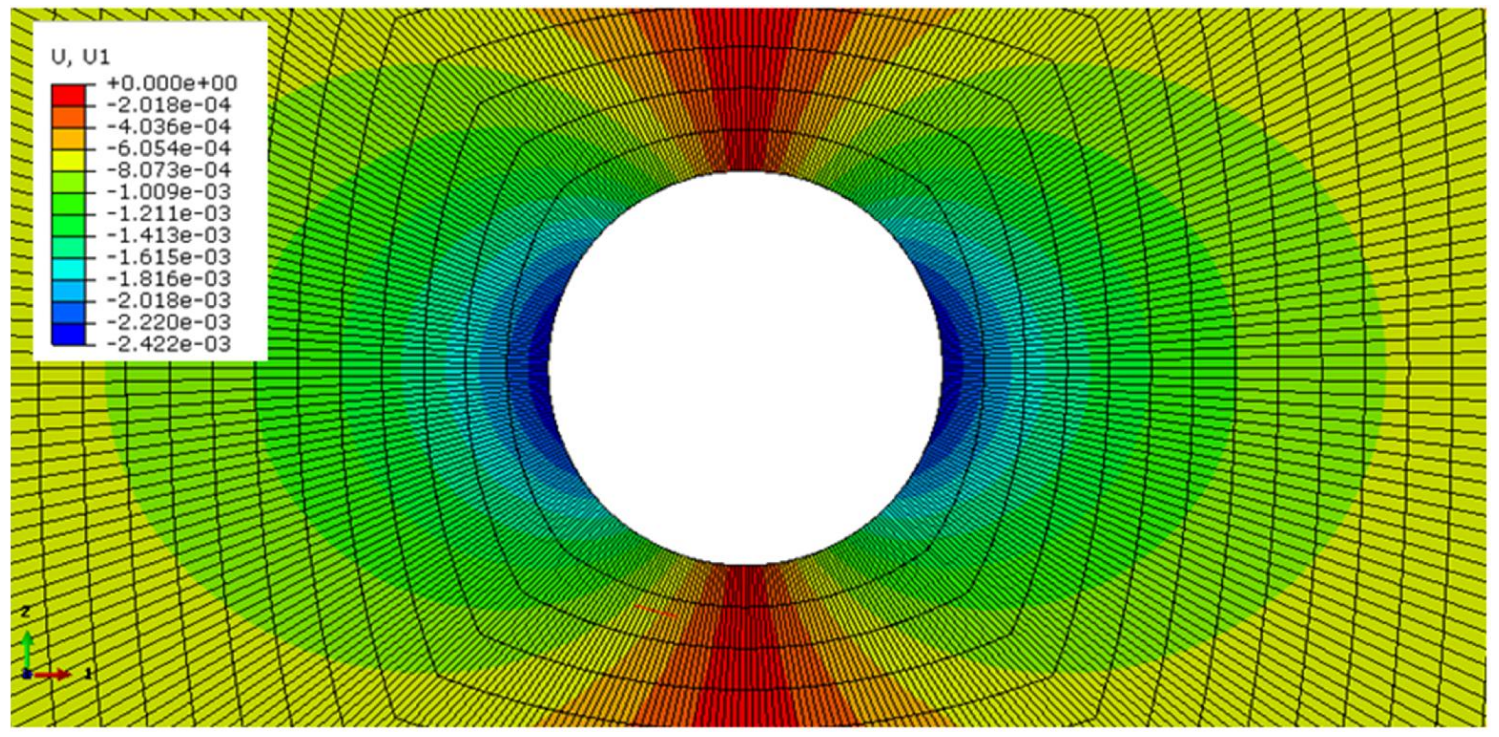

Figura 4-18 - Deslocamento em metros no sentido do eixo 1 em um período de um mês de fluência após a escavação (etapa 3).

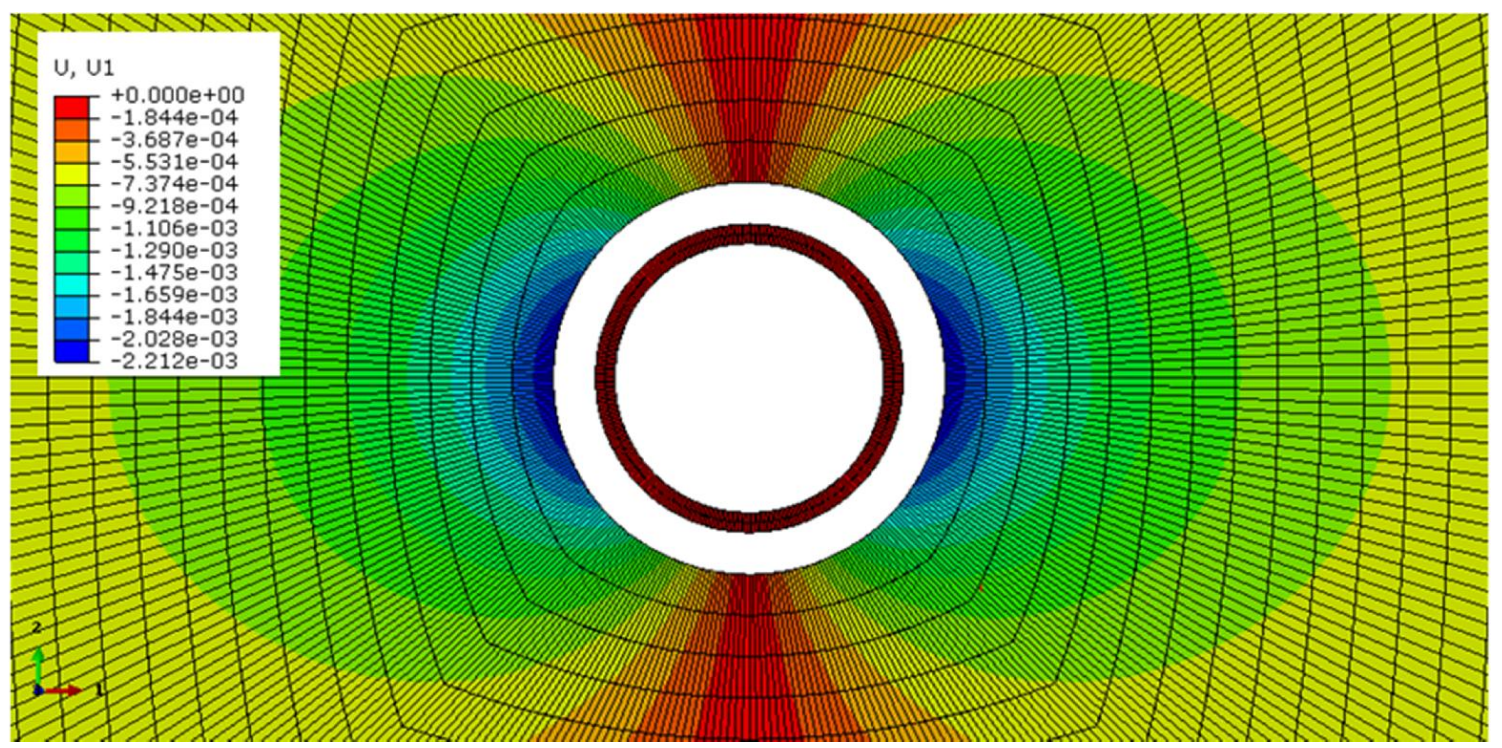

Figura 4-19 - Deslocamento em metros no sentido do eixo 1 após a instalação do revestimento e aplicação do cimento em estado líquido (etapa 6). 


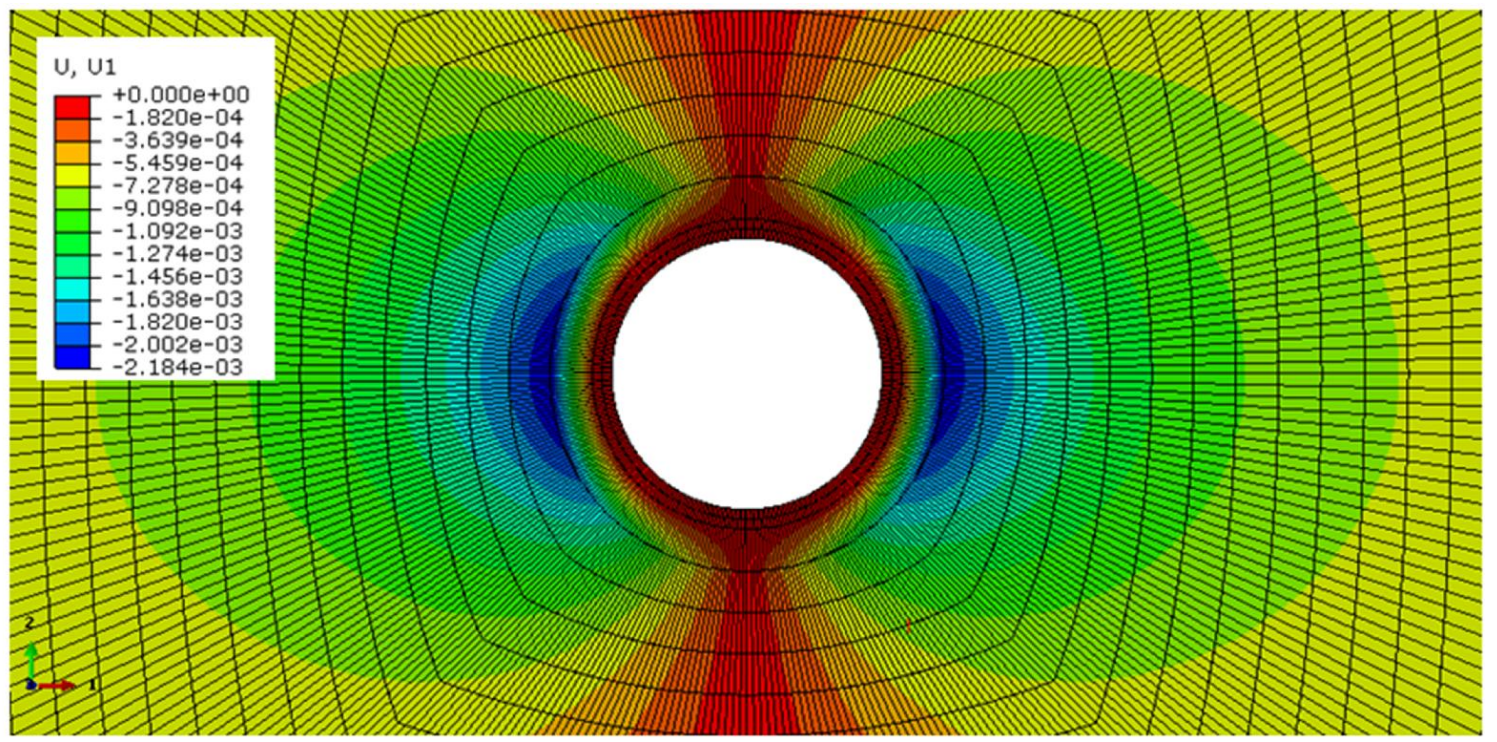

Figura 4-20 - Deslocamento em metros no sentido do eixo 1 após o processo de endurecimento do cimento (etapa 27).

\subsubsection{Deformações}

As análises de deformações radiais na parede do poço, apresentadas na Figura 4-21, foram realizadas considerando a utilização dos diferentes pesos de fluido de perfuração, mostrados na Tabela 4-5, para um período de fluência de um mês após a escavação do poço (etapa 3) e após o completo processo de endurecimento do cimento (etapa 27). Os cálculos de deformações foram feitos em um nó na parede do poço (nó 3) mostrado na Figura 4-11.

Analisando as deformações após a terceira etapa da simulação, tem-se que para o peso de fluido de perfuração de 9 ppg a deformação na parede do poço foi de $14,7 \%$, enquanto que para o fluido de maior peso, 13 ppg, essa deformação foi de 1,4\%. Observa-se que quanto menor o peso do fluido de perfuração aplicado durante a escavação, maiores as deformações radiais.

Ao instalar o revestimento e aplicar o cimento em estado líquido, inicia-se o processo de endurecimento do cimento e este adquire o seu valor final de rigidez. Com a aplicação da pressão do fluido do cimento ocorre uma pequena diminuição da deformação na parede do poço. Durante o processo de endurecimento do cimento essa deformação diminui discretamente, mantendo-se praticamente constante até o seu completo ganho de rigidez. Desta forma, com a instalação do revestimento e cimentação do poço, as deformações podem ser estabilizadas no tempo. Como exemplo, tem-se que para um peso de fluido de perfuração de 11 ppg a deformação após um período de um mês da escavação do poço foi de 5,8\%. Após 
o processo de endurecimento do cimento, a deformação na parede do poço passou a ser de $5,5 \%$.

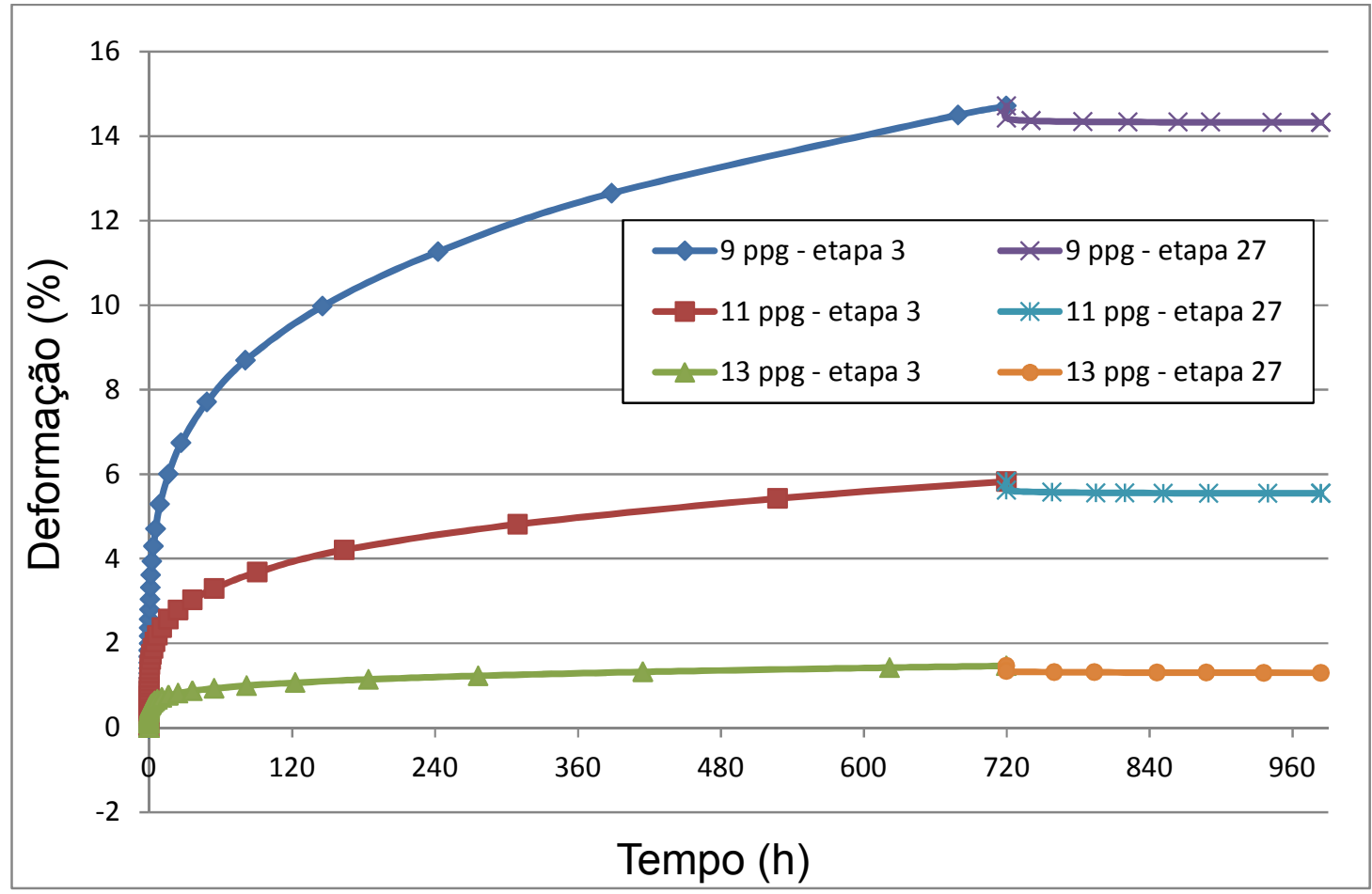

Figura 4-21 - Deformações radiais na parede do poço em um período de um mês de fluência após a escavação (etapa 3) e após o completo processo de endurecimento do cimento (etapa 27), para os diferentes pesos do fluido de perfuração.

A Figura 4-22 apresenta as deformações no sentido do eixo 1, por uma escala de cores no Abaqus ${ }^{\circledR}$, com peso do fluido de perfuração de 11 ppg, em um período de um mês de fluência após a escavação do poço (Figura 4-22a) e após o completo endurecimento do cimento (Figura 4-22b). 

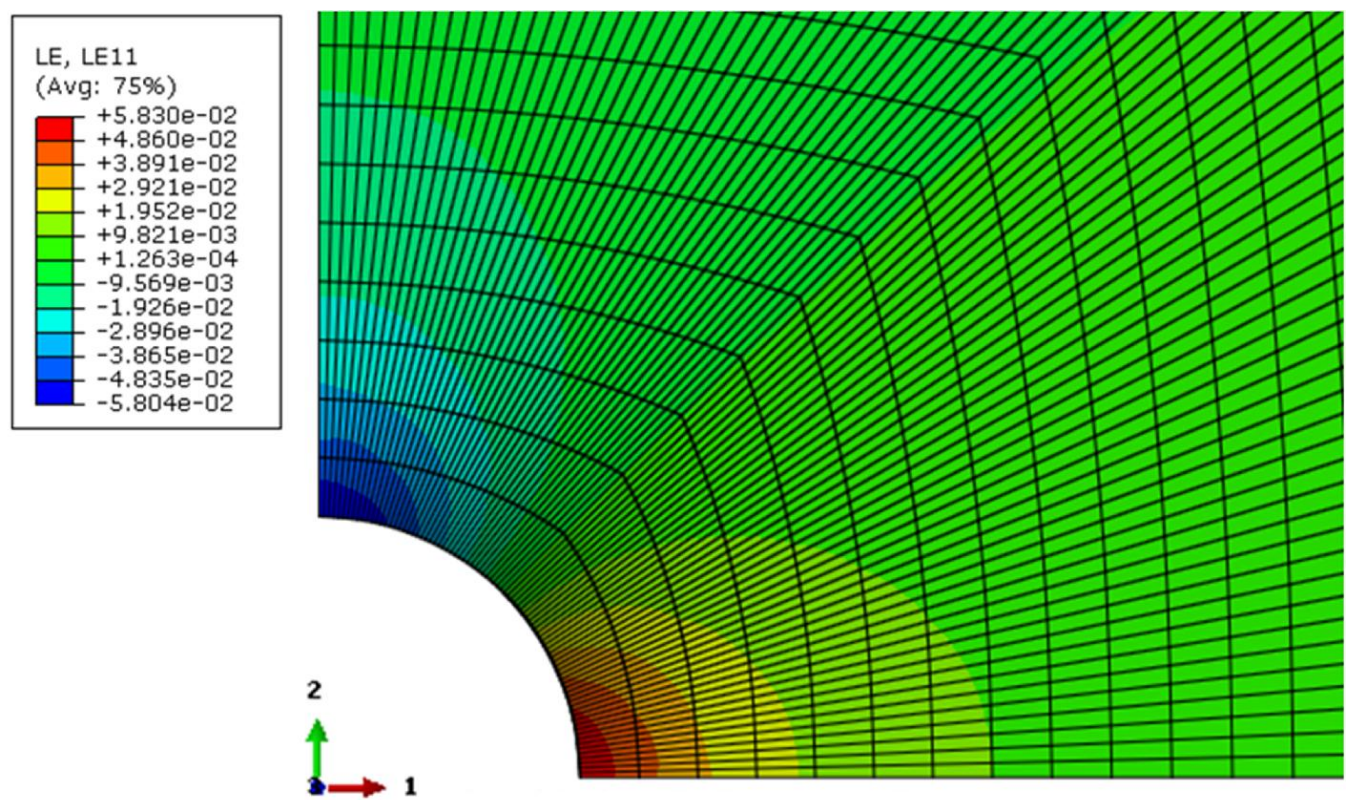

(a)
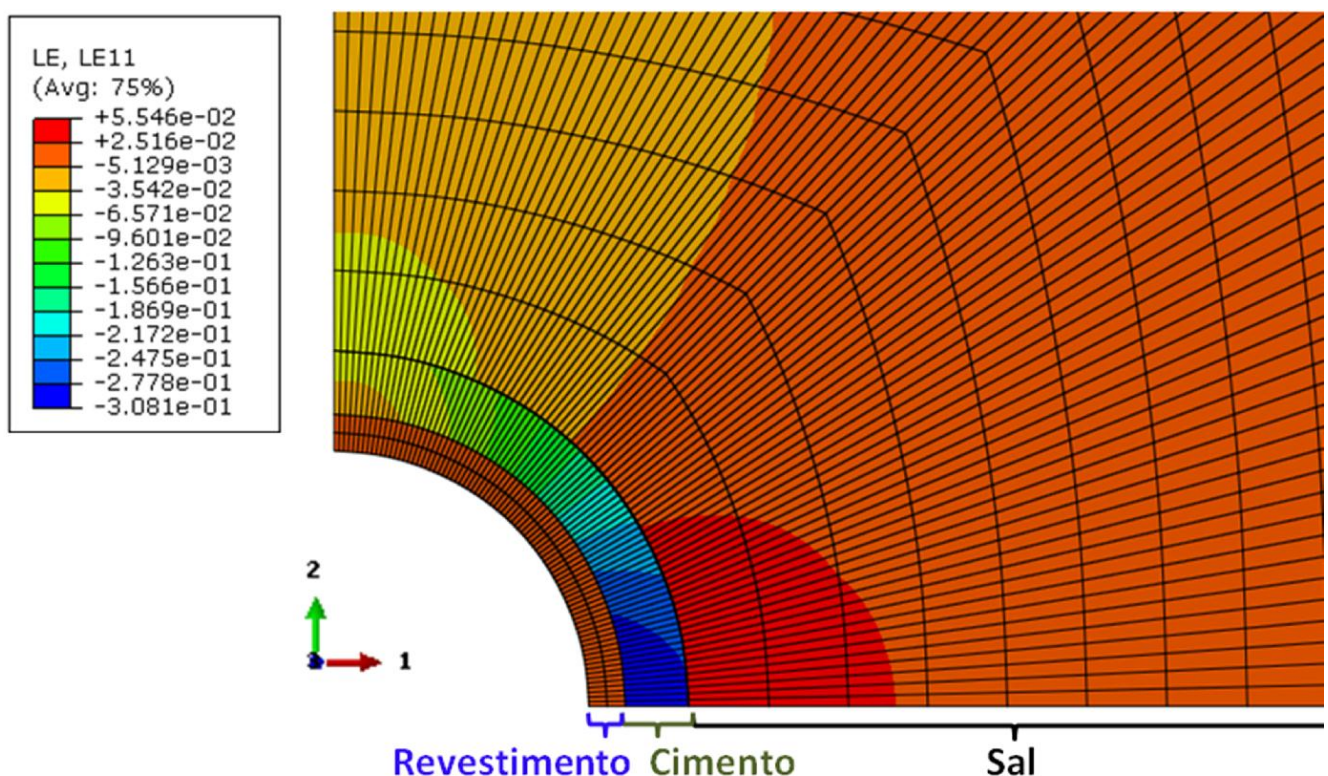

(b)

Figura 4-22 - Deformações radiais na parede do poço: (a) em um período de um mês de fluência após a escavação - etapa 3 e; (b) após o completo processo de endurecimento do cimento - etapa 27. Para obter os valores em porcentagem, deve-se multiplicar os resultados apresentados pelo Abaqus ${ }^{\circledR}$ por 100.

\subsubsection{Tensões}

As análises das tensões são realizadas para a aplicação do fluido de perfuração com peso de 13 ppg. A Figura 4-23 apresenta as tensões radiais e tangenciais ao redor do poço 
considerando um período de fluência de um mês após a escavação. A análise é realizada a partir do centro do poço até uma distância de 20 vezes o raio do poço $(3,10 \mathrm{~m})$. O valor negativo das tensões indica que está havendo esforço de compressão, conforme a convenção do Abaqus ${ }^{\circledR}$. Observando a Figura 4-23, percebe-se que as tensões radiais igualam-se às tensões in situ nas regiões mais remotas ao poço.

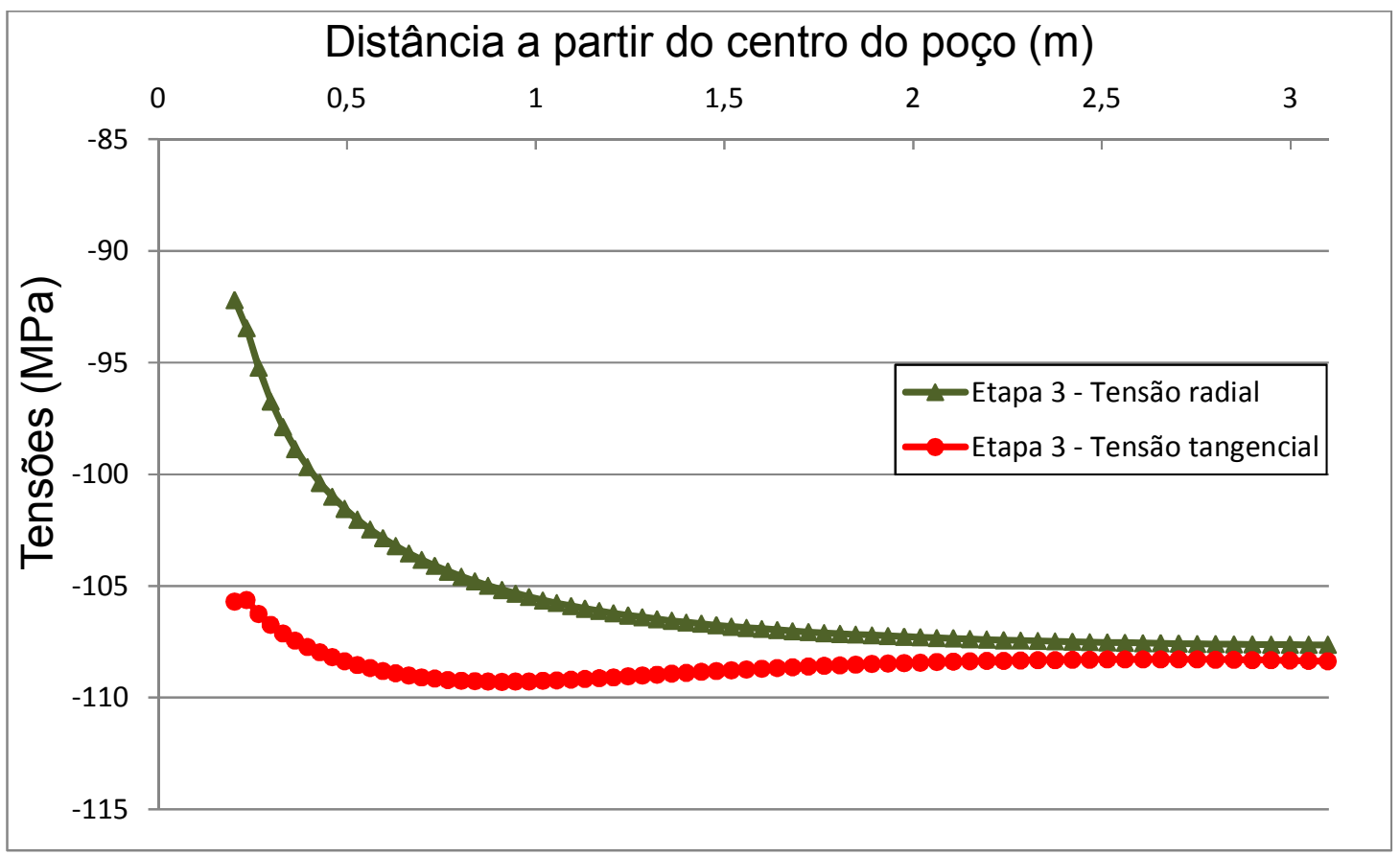

Figura 4-23 - Tensões ao redor do poço em um período de 30 dias de fluência após a escavação, para um peso de fluido de perfuração de 13 ppg.

Ainda, analisam-se as tensões durante o processo de endurecimento do cimento, cujo ganho de rigidez foi simulado em 11 etapas. O gráfico da Figura 4-24 mostra o comportamento da tensão radial no início do processo de endurecimento do cimento (etapa 7) e no momento em que o cimento adquiriu a sua rigidez final (etapa 27). A Figura 4-25 apresenta o comportamento da tensão tangencial durante a etapa 7 e etapa 27. Para esses gráficos, o eixo das abscissas representa a distância a partir do centro do poço até $0,525 \mathrm{~m}$. Essa distância foi escolhida para que seja possível observar as tensões nas regiões próximas ao poço. Ainda, nessa distância as tensões seguem praticamente constantes até as regiões mais remotas ao poço, sendo igualadas às tensões in situ. 


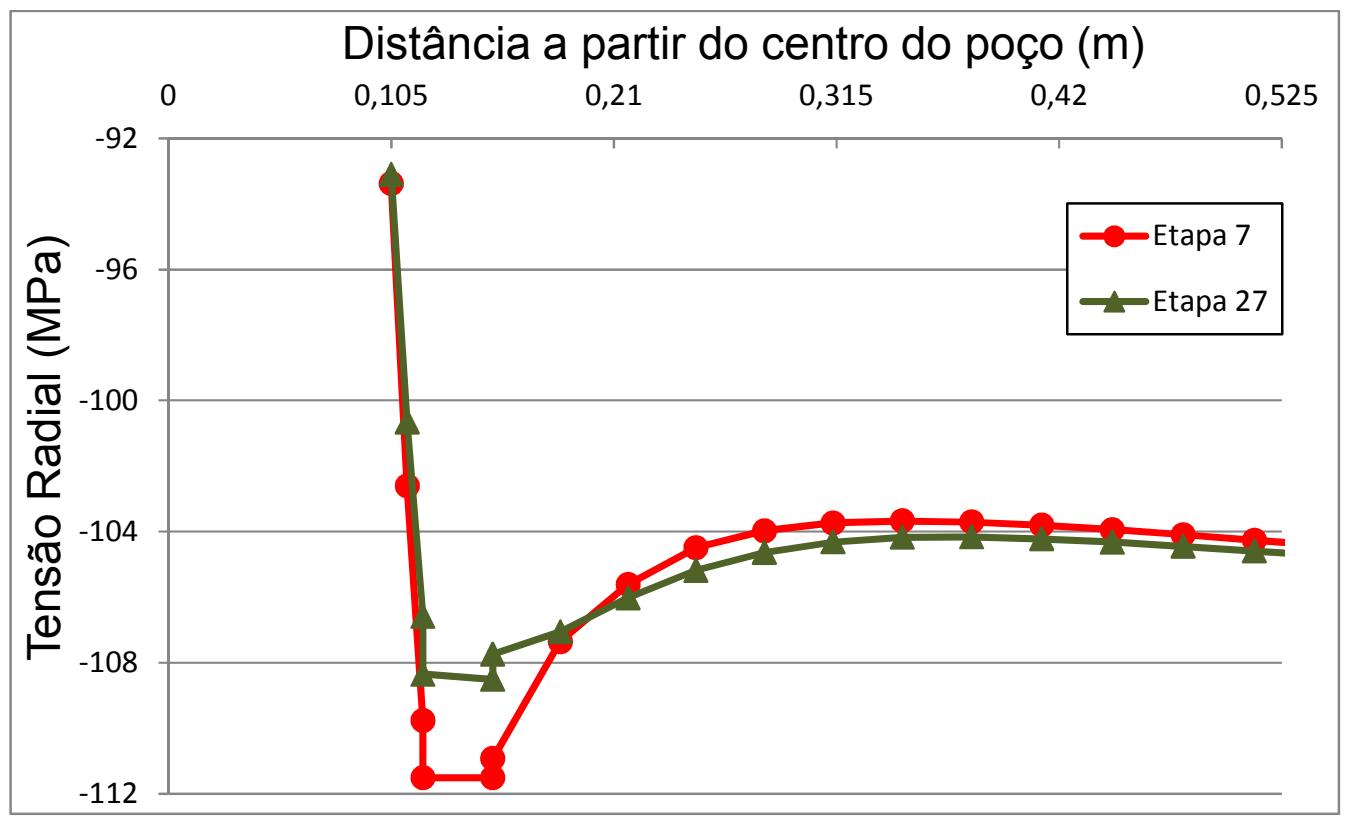

Figura 4-24 - Tensão radial ao redor do poço na etapa 7 e na etapa 27.

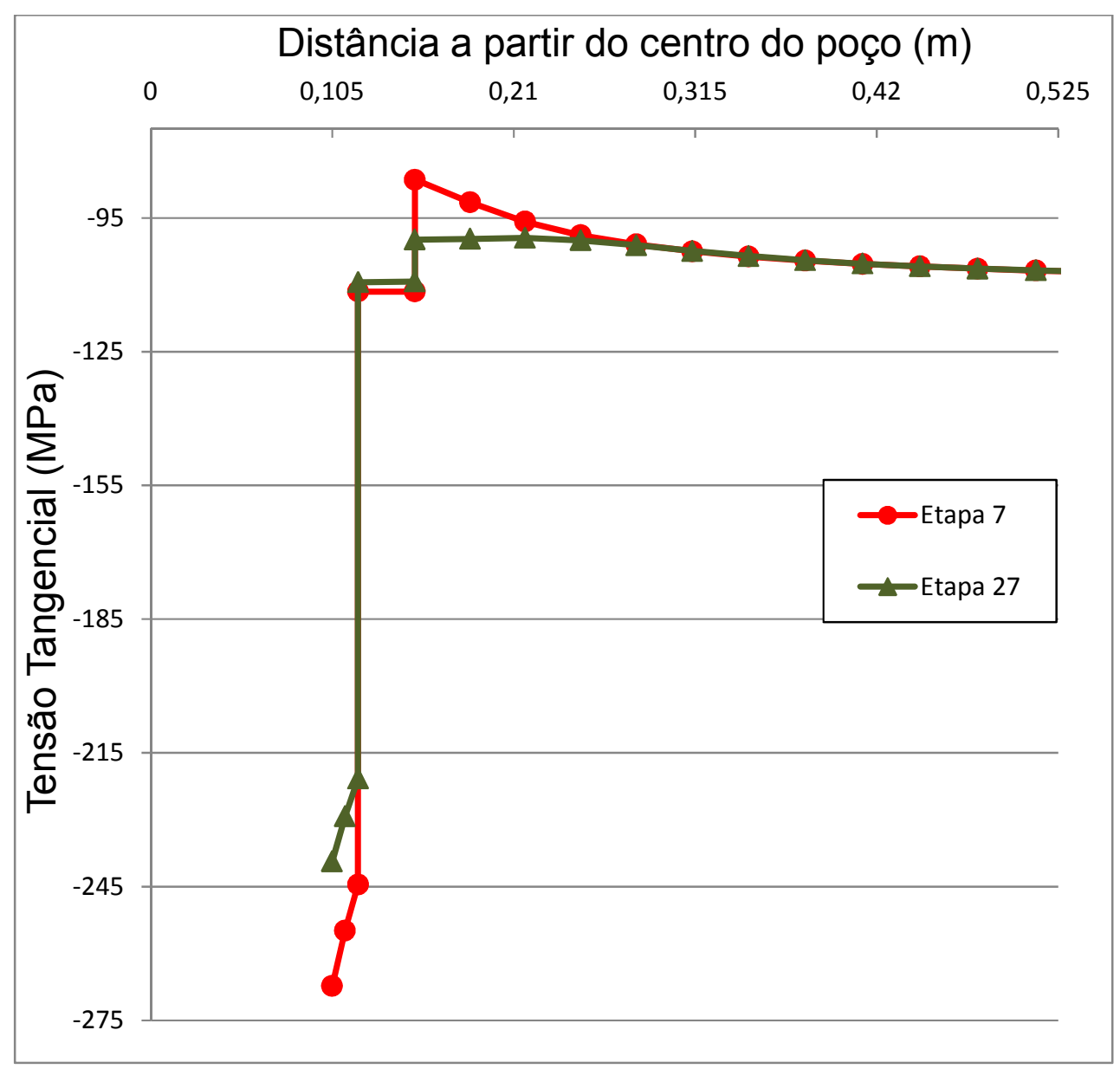

Figura 4-25 - Tensão tangencial ao redor do poço na etapa 7 e na etapa 27. 
$\mathrm{Na}$ parte interna do revestimento o fluido de perfuração é continuamente aplicado, com isso a tensão radial se mantém constante nessa região. Na interface revestimento-cimento ocorre uma discreta redução da tensão radial. Com o ganho de rigidez do cimento, a tensão tangencial no revestimento diminui.

Observando o cimento, percebe-se que ocorre uma discreta redução da tensão tangencial e radial, mantendo-se em estado de compressão durante toda a análise. Na interface cimento-sal, tem-se uma redução na tensão radial durante o processo do ganho de rigidez do cimento. Em relação à tensão tangencial, observa-se um aumento em sua magnitude ao longo das etapas de simulação (etapa 7- etapa 27). Essa pequena diferença entre as tensões em cada passo da análise determina o deslocamento na parede do poço, no sentido de conter o seu fechamento, decorrente do endurecimento do cimento.

No revestimento foi analisada a tensão de von Mises após o processo de endurecimento do cimento. Analisando o gráfico da Figura 4-26, percebe-se que o revestimento não apresentou comportamento plástico, pois as tensões atuantes não geraram uma tensão equivalente de von Mises superior a tensão de escoamento.

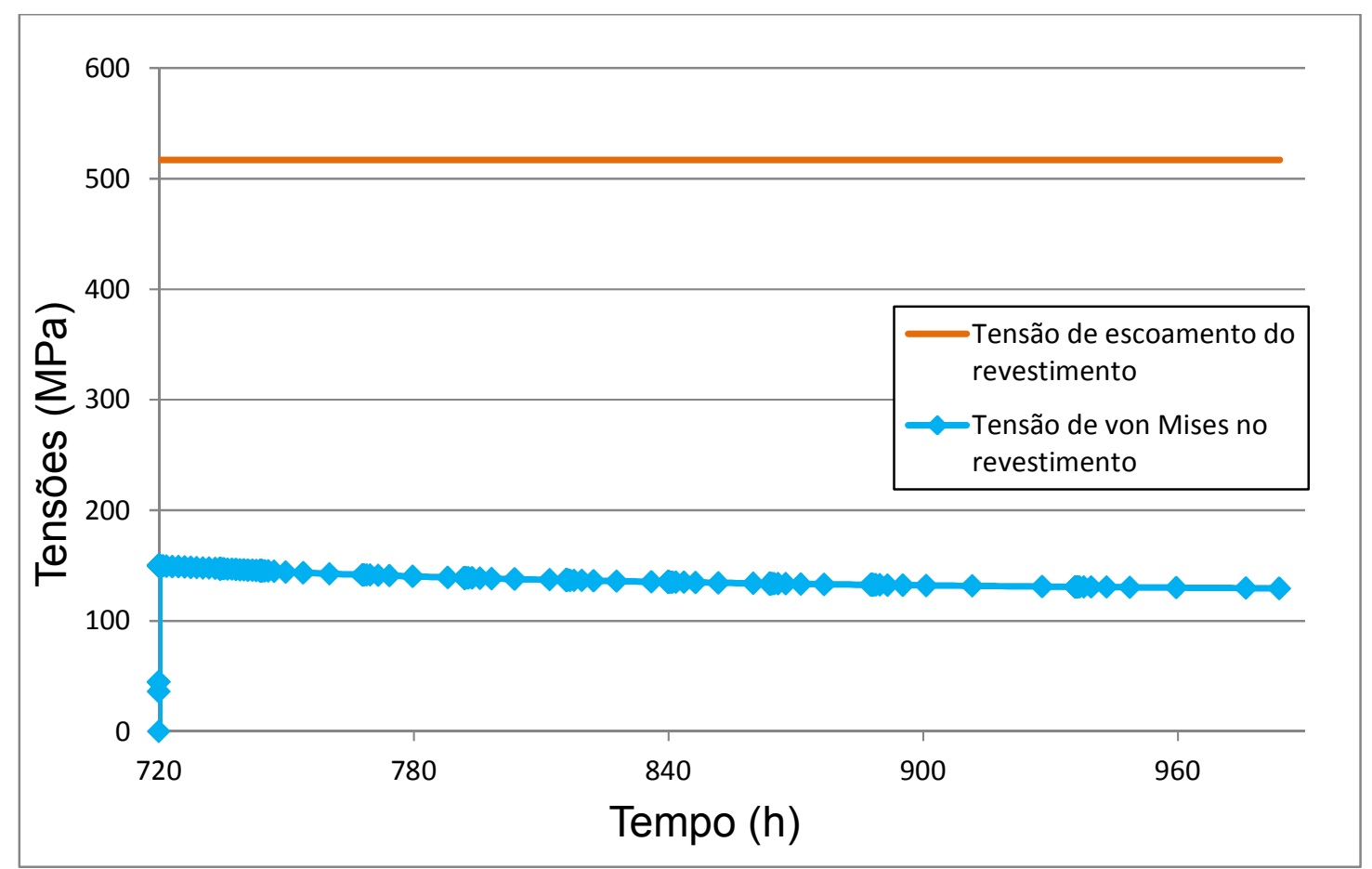

Figura 4-26 - Tensão de von Mises no revestimento. 


\subsubsection{Validação do resultado para o revestimento}

Para verificar o comportamento do revestimento quando aplicadas as pressões do fluido do cimento e do fluido de perfuração (etapas 5, 6 e 7), compara-se a solução numérica com a solução analítica. Esta solução analítica, baseada na teoria da elasticidade, considera a seção transversal de um tubo de revestimento, submetido à pressão interna e pressão externa, como representada na Figura 4-27.

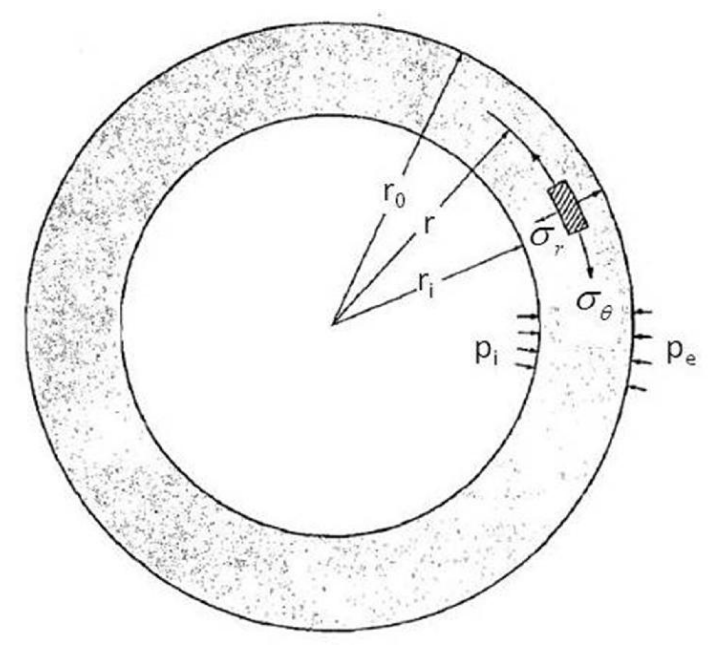

Figura 4-27 - Seção transversal de um tudo de revestimento submetido às pressões interna e externa.

A tensão radial $\left(\sigma_{r}\right)$ e a tensão tangencial $\left(\sigma_{\theta}\right)$ da solução analítica, em qualquer raio $(r)$ entre o raio interno $\left(r_{i}\right)$ e o raio externo $\left(r_{0}\right)$, são dadas por (Bourgoyne Júnior et al., 1986):

$$
\begin{aligned}
& \sigma_{r}=\frac{-p_{i} \cdot r_{i}^{2} \cdot\left(r_{0}^{2}-r^{2}\right)-p_{e} \cdot r_{0}^{2} \cdot\left(r^{2}-r_{i}^{2}\right)}{r^{2} \cdot\left(r_{0}^{2}-r_{i}^{2}\right)} \\
& \sigma_{\theta}=\frac{p_{i} \cdot r_{i}^{2} \cdot\left(r_{0}^{2}+r^{2}\right)-p_{e} \cdot r_{0}^{2} \cdot\left(r^{2}+r_{i}^{2}\right)}{r^{2} \cdot\left(r_{0}^{2}-r_{i}^{2}\right)}
\end{aligned}
$$

onde,

$\sigma_{r}$ é a tensão radial;

$\sigma_{\theta}$ é a tensão tangencial;

$p_{i}$ é a pressão do fluido na região interna do revestimento;

$p_{e}$ é a pressão do fluido na região externa do revestimento;

$r_{i}$ é o raio interno do revestimento; 
$r_{0}$ é o raio externo do revestimento; e

$r$ é a distância medida entre o raio interno $\left(r_{i}\right)$ e o raio externo $\left(r_{0}\right)$.

$\mathrm{Na}$ quarta etapa da simulação, tem-se a representação da execução do revestimento, o qual recebe a pressão do fluido de perfuração atuando nas partes externa e interna do revestimento, como representado na Figura 4-28. Para esta análise, considera-se a aplicação do peso do fluido de perfuração de 13 ppg (90,9 MPa).

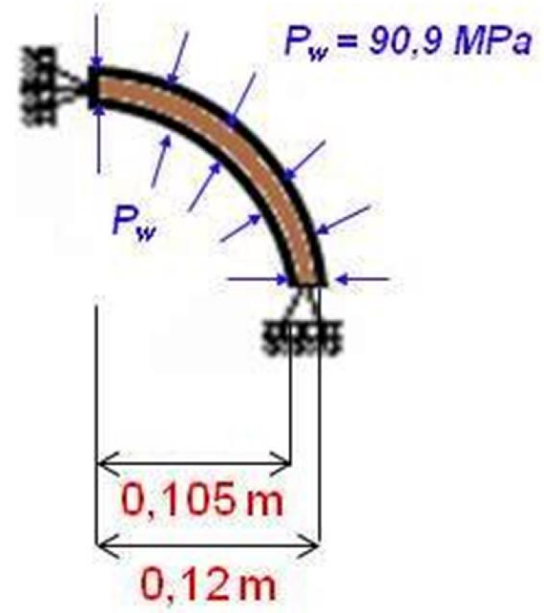

Figura 4-28 - Detalhe da pressão do fluido de perfuração aplicada ao revestimento na etapa 4.

Comparando os resultados numéricos com as respostas analíticas para esta etapa, obtém-se o gráfico da Figura 4-29. Pode-se observar que os resultados numéricos coincidem com os resultados obtidos com a solução analítica, apresentando um erro de 0,01\%.

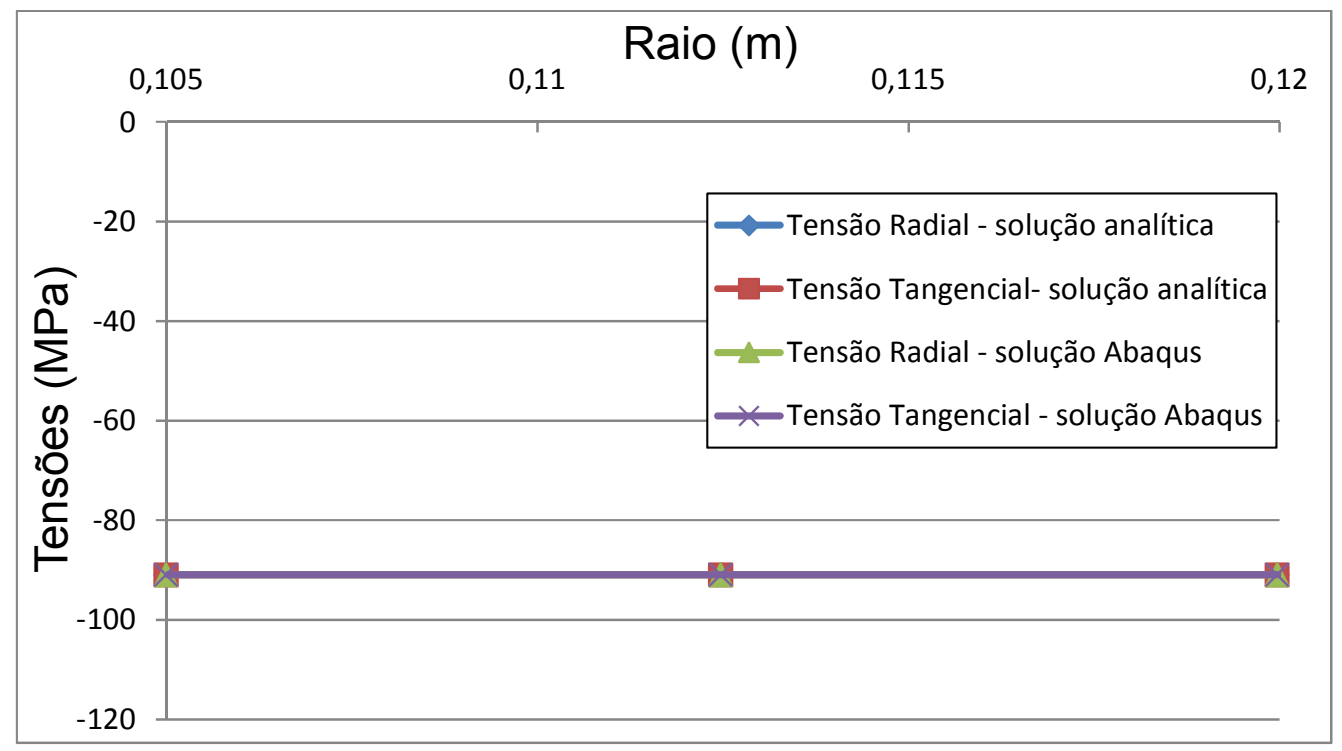

Figura 4-29 - Solução analítica versus Abaqus ${ }^{\circledR}$ : etapa $4-p_{i}=P_{w}=90,9 \mathrm{MPa} ; p_{e}=P_{w}=90,9 \mathrm{MPa}$. 
Após a execução do revestimento, o cimento é inserido no estado líquido, ocasionando uma pressão do fluido do cimento na parte externa e interna do revestimento, como apresentado na Figura 4-30.

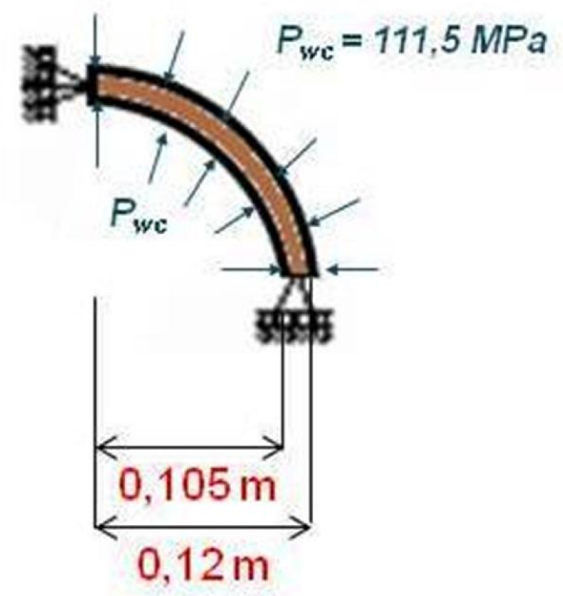

Figura 4-30 - Detalhe da pressão do fluido de cimento aplicada ao revestimento na etapa 5.

Ao comparar os resultados numéricos com os resultados analíticos, na etapa 5, apresentados na Figura 4-31, percebe-se que as respostas numéricas e analíticas são coincidentes, com erro percentual praticamente nulo.

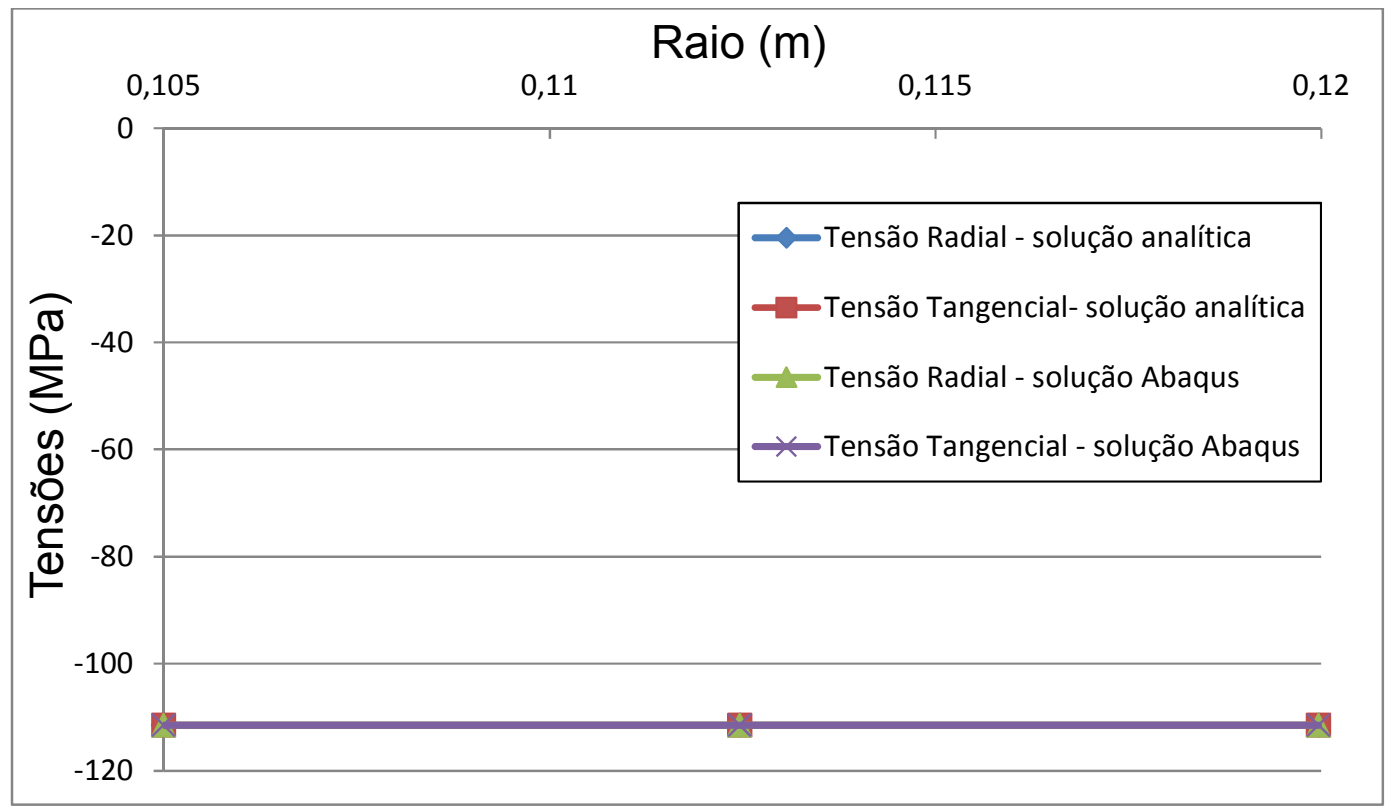

Figura 4-31 - Solução analítica versus Abaqus ${ }^{\circledR}$ : etapa $5-p_{i}=P_{w c}=111,5 \mathrm{MPa} ; p_{e}=P_{w c}=111,5 \mathrm{MPa}$. 
$\mathrm{Na}$ etapa 6, tem-se a aplicação da pressão do fluido de perfuração no interior do revestimento e a pressão do fluido de cimento na região externa do revestimento (Figura 4$32)$.

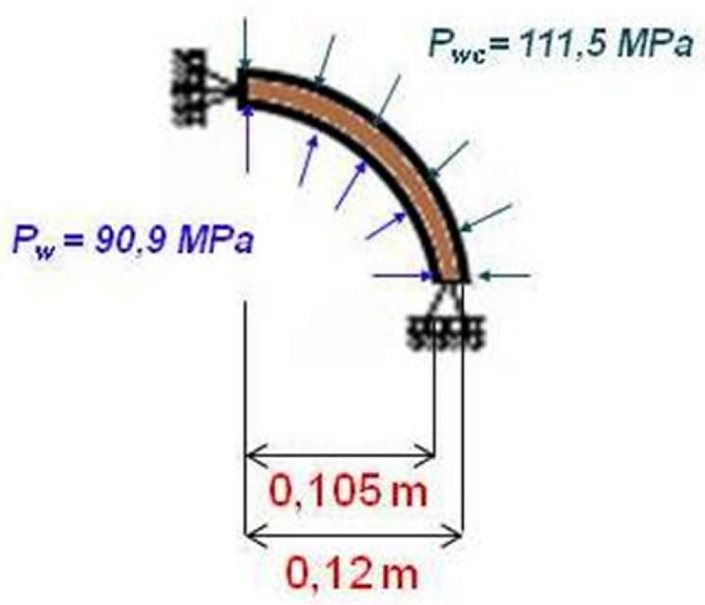

Figura 4-32 - Detalhe das pressões dos fluidos de perfuração e cimento aplicadas ao revestimento na etapa 6.

Para esta etapa, as soluções numérica e analítica são confrontadas na Figura 4-33 e é verificado que praticamente os mesmos valores são obtidos, com erro de 1,5\% nas tensões radiais e $0,6 \%$ nas tensões tangenciais.

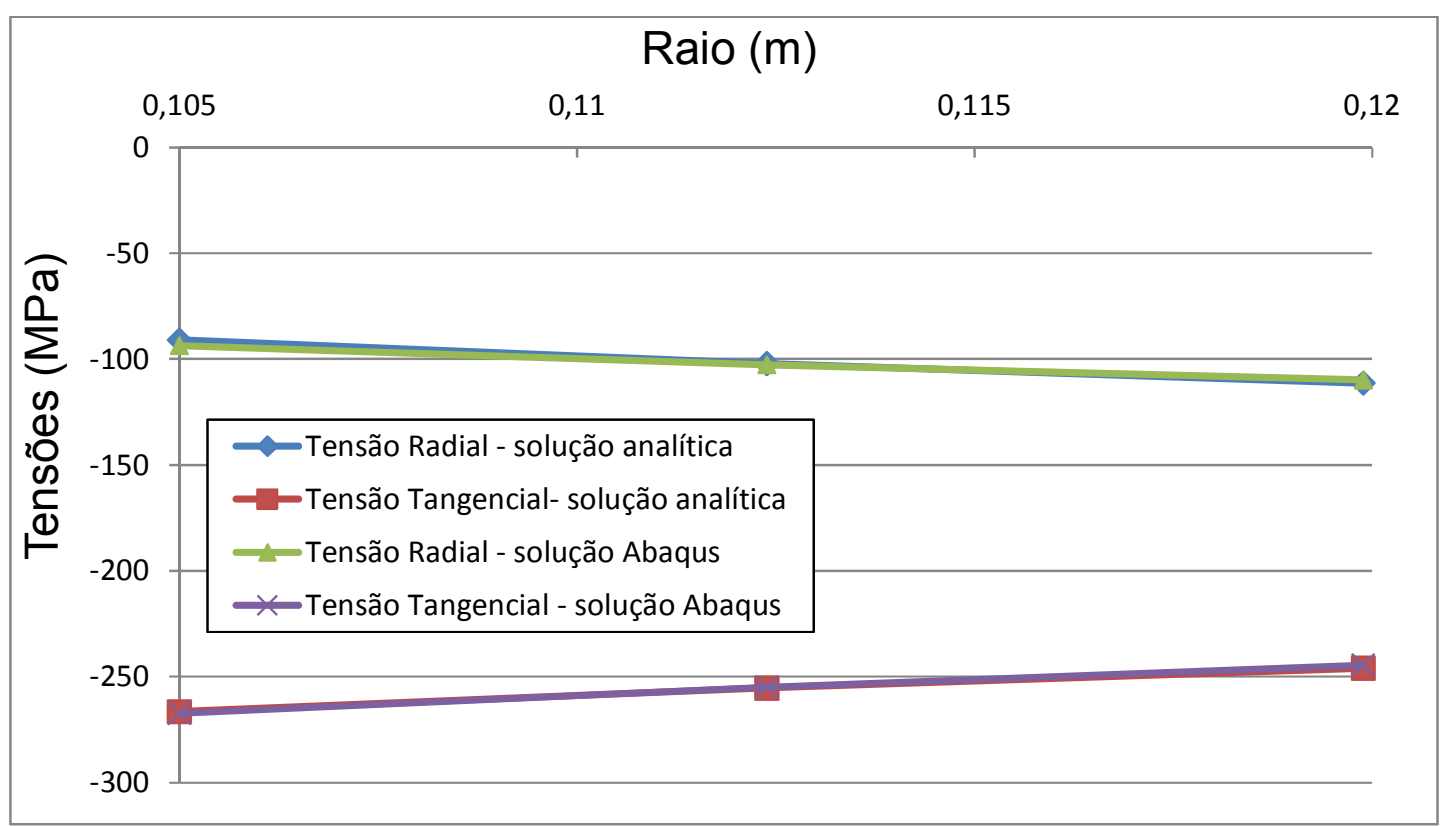

Figura 4-33 - Solução analítica versus Abaqus®: etapa $6-p_{i}=P_{w}=90,9 \mathrm{MPa} ; p_{e}=P_{w c}=111,5 \mathrm{MPa}$. 
Com os resultados apresentados na Figura 4-29, Figura 4-31 e Figura 4-33, tem-se a validação dos resultados numéricos obtidos para as etapas 4, 5 e 6, respectivamente, para o revestimento submetido à pressão nas regiões interna e externa. Desta forma $o$ comportamento do revestimento devido às pressões a que é exposto está condizente com os resultados obtidos analiticamente. 
Capítulo 5

CONCLUSÕES E SUGESTÕES DE TRABALHOS FUTUROS 


\section{CONCLUSÕES E SUGESTÕES DE TRABALHOS FUTUROS}

As modelagens computacionais das etapas de perfuração, revestimento e cimentação de um poço de petróleo em zona salina foram realizadas com o programa comercial de elementos finitos Abaqus ${ }^{\circledR}$ e possibilitaram os estudos sobre o comportamento de fluência do sal e o processo de endurecimento do cimento.

Os estudos sobre o comportamento da perfuração de um poço de petróleo em evaporito permitiram, em uma etapa inicial, um entendimento do processo de redistribuição do estado de tensões com o tempo. As análises através do modelo plano de deformação e modelo axissimétrico demonstraram que a estabilidade do poço em relação ao seu fechamento devido à fluência do sal é mais crítica nos primeiros instantes após a perfuração, para rochas com as características do modelo analisado. Visando a garantir a segurança na escavação e posterior produção do poço, simularam-se as etapas de revestimento e cimentação. Ainda, foi analisada a importância da escolha do fluido de perfuração a ser aplicado.

No modelo plano de deformação foi simulada numericamente a perfuração de um poço em uma seção horizontal a $6000 \mathrm{~m}$ de profundidade abaixo do nível do mar. Analisou-se o comportamento do sal até a etapa de fluência após a escavação do poço para diferentes pesos de fluido de perfuração. Para este modelo, buscou-se a verificação da dimensão da geometria utilizada para a análise, bem como a sua validação por meio da comparação com as soluções analíticas de Kirsch (1898) e Bradley (1979). Esta comparação mostrou um bom ajuste dos resultados para a geometria adotada no modelo plano de deformação.

No estudo do modelo axissimétrico foi realizada a escavação por estágios desde uma profundidade de $6000 \mathrm{~m}$ até $6020 \mathrm{~m}$ abaixo do nível do mar. O acompanhamento deste avanço na escavação também permitiu verificar a influência da perfuração no comportamento do sal. A definição da dimensão lateral deste modelo e o estudo da sensibilidade no refinamento da malha foram realizados e comparados com a solução analítica de Panet (1979). Ainda, foi realizada a modelagem numérica do modelo axissimétrico considerando a variação da tensão de sobrecarga com a profundidade, o que ocasionou um aumento das tensões horizontais. A pressão exercida pelo fluido de perfuração na parede do poço escavado também foi simulada variando com a profundidade em que está sendo aplicada.

Os deslocamentos radiais decorrentes da perfuração do poço na camada salina para estes dois modelos de análise, após um período de fluência do sal de um mês antes da instalação do revestimento, foram maiores quanto menores os pesos de fluidos de perfuração 
utilizados. O mesmo fato foi evidenciado nas análises de deformações. Isso ocorreu devido a maior diferença entre as tensões in situ e as pressões provocadas pelo fluido de perfuração de menor peso. Os deslocamentos e as deformações foram analisadas levando em consideração a solução elástica e a solução por fluência do sal. Percebeu-se que os deslocamentos e deformações gerados apenas pela solução elástica do sal são pequenos quando comparados com os deslocamentos e deformações causados por fluência.

O estudo do comportamento dos deslocamentos nas regiões mais remotas ao poço foi realizado com a análise de deformação plana, a qual permitiu observar que independentemente do peso de fluido de perfuração utilizado na simulação, os deslocamentos foram maiores na parede do poço e decresceram à medida que se afastavam dele. Como na região próxima à parede do poço acorre uma maior perturbação nas tensões devido à escavação, quanto mais afastado do poço, menores perturbações de tensões ocorrem e, consequentemente, menores deslocamentos por fluência.

Outra análise importante realizada com o modelo plano de deformação e modelo axissimétrico foi em relação ao comportamento das tensões na parede do poço e nas regiões mais remotas a ela, em um período de um mês de fluência do sal após a escavação do poço. Com a análise plana, pôde-se perceber que as grandes redistribuições de tensões ocorreram no primeiro dia de fluência após a escavação e se mantiveram praticamente constantes até trinta dias de análise. Tal fato confirmou a necessidade da consideração de fluência nos primeiros instantes após a escavação do poço. Ainda, observou-se que tanto na análise de deformação plana quanto na análise axissimétrica, ao utilizar maiores pesos do fluido de perfuração, menores foram as diferenças entre as tensões próximas ao poço, tensões radiais e tangenciais, e a tensão inicial antes da perfuração. Tal fato ocasionou uma menor fluência devido ao menor relaxamento das tensões.

Posteriormente a escavação do poço e um período de fluência de trinta dias que antecederam a descida do revestimento, o mesmo foi instalado e o espaço anular entre o revestimento e as paredes do poço foi preenchido com cimento. Inicialmente, o cimento foi inserido no estado líquido e durante seu processo de endurecimento adquiriu o valor da sua rigidez final após um período de onze dias. A modelagem numérica da perfuração do poço de petróleo em evaporito, com a realização das etapas de revestimento e cimentação, foi realizada levando em consideração o modelo plano de deformação. As análises das etapas de revestimento e cimentação do poço englobaram tanto o processo de endurecimento do cimento quanto a resposta de fluência do sal. No processo de endurecimento do cimento os parâmetros elásticos variaram a cada passo da simulação. 
Antes da simulação com o ganho de rigidez do cimento no tempo foi verificado o comportamento na parede do poço ao aplicar diferentes condições de rigidez para o cimento (infinita, nula e intermediária). Esses valores foram mantidos constantes durante os onze dias desde a sua aplicação. Para a condição do cimento com rigidez intermediária o deslocamento na parede do poço foi um valor entre os obtidos quando realizadas as análises com rigidez nula e infinita. Assim, o deslocamento na parede do poço quando o cimento adquiriu maior rigidez ao longo do tempo foi inferior ao deslocamento causado pela aplicação do cimento em sua fase líquida (rigidez nula).

O ganho de rigidez do cimento aconteceu no decorrer das 21 etapas da simulação, desde a ativação da malha do cimento, sendo intercaladas em uma simulação elástica e outra simulação de fluência do sal. Ainda, foi aplicado o fluido de perfuração na parte interna do revestimento que atuou durante todo o processo de endurecimento do cimento. Foram realizadas análises dos deslocamentos na parede do poço durante o processo de endurecimento do cimento para os diferentes pesos do fluido de perfuração, bem como o comportamento das tensões no revestimento, cimento e formação circundante ao poço. As deformações por fluência do sal foram analisadas antes da instalação do revestimento e depois do ganho de rigidez do cimento.

Após o cimento adquirir seu valor final de rigidez, percebeu-se que foi possível conter o deslocamento por fluência do sal, evitando a continuidade do fechamento do poço e garantindo a sua integridade, independentemente do peso do fluido de perfuração utilizado. A deformação na parede do poço diminuiu discretamente e se manteve praticamente constante até o completo ganho de rigidez do cimento, estabilizando as deformações no tempo.

As tensões radiais e tangenciais no sal convergiram para os valores das tensões no meio contínuo nas regiões mais remotas ao poço. No entanto, perto da fronteira cimento - sal, com o ganho de rigidez do cimento, ocorreu uma pequena redução da tensão radial e um aumento na tensão tangencial ao longo das etapas de simulação. No cimento, percebeu-se uma discreta redução da tensão tangencial e radial. Na interface revestimento-cimento ocorreu uma discreta redução da tensão radial e uma diminuição da tensão tangencial. No revestimento as tensões atuantes não geraram uma tensão equivalente de von Mises superior à tensão de escoamento e, desta forma, não se apresentou comportamento plástico.

Ainda, para verificar o comportamento do revestimento quando aplicadas as pressões do fluido do cimento e do fluido de perfuração, comparou-se a solução numérica com a solução analítica. Esta solução analítica foi baseada na teoria da elasticidade considerando uma seção transversal de um tubo de revestimento, submetido à pressão interna e pressão 
externa. Ao confrontar os resultados, pôde-se notar que o comportamento numérico do revestimento devido às pressões o qual foi exposto está condizente com os resultados obtidos analiticamente.

Com todas as análises discutidas, conclui-se que no comportamento de fluência do sal existe uma interdependência do processo de redistribuição e relaxação do estado de tensões com as deformações. Ainda, verificou-se a importância da escolha adequada do peso do fluido de perfuração e da consideração da fluência nos primeiros instantes após a escavação do poço. Os valores de deslocamentos e deformações por fluência dependem intrinsecamente da lei de fluência e dos parâmetros adotados na modelagem numérica. Uma vez alterados estes parâmetros, ocorrem diferentes deformações. Assim, os parâmetros elásticos e as constantes empíricas de fluência devem ser bem definidos para que se tenha a simulação o mais próximo possível da realidade.

Com a execução das etapas de revestimento e cimentação do poço, pôde-se observar a sua importância para conservar a segurança do poço durante a perfuração e posterior produção. O processo do endurecimento do cimento permitiu que houvesse um menor deslocamento do sal no sentido do fechamento do poço.

Este trabalho serviu como contribuição para o estudo do comportamento do evaporito durante as etapas de escavação, revestimento e cimentação do poço de petróleo. A simulação foi realizada com a lei de fluência disponibilizada pelo Abaqus ${ }^{\circledR}$. Uma recomendação para um trabalho futuro seria utilizar uma lei constitutiva de fluência que melhor represente este problema em evaporitos, reproduzindo a deformação instantânea, deformação na fase de fluência primária e fluência secundária. Ainda, analisar o processo sugerindo uma cimentação primária deficiente, de forma a necessitar da execução da cimentação secundária. 


\section{REFERÊNCIAS}

Abaqus ${ }^{\circledR}-6.12$ : documentation. 2012. Disponível em: $<$ http://www.maths.cam.ac.uk/computing/software/abaqus_docs/docs/v6.12/>. Acesso em: 10 Jan. 2013.

ALVES, I. A. S. et al. Well construction learning curve acceleration. In: OFFSHORE TECHNOLOGY CONFERENCE, 2009, Houston. Proceedings... [S.1.:s.n.], 2009. (Paper OTC 20177).

AMARAL, C. S. et al. Reavaliação do comportamento do poço 1-RJS-480 por ocasião do fechamento do revestimento de 9 5/8" no trecho de travessia da zona de sal. Rio de Janeiro: PETROBRÁS, 1999. (Relatório PETROBRAS/CENPES/DIPREX/SEDEM-013).

BATHE, K. J. Finite element procedures. New Jersey: Prentice-Hall International, 1996.

BELTRÃO, R. L. C. et al. Challenges and new technologies for the development of the presalt cluster, Santos Basin, Brazil. In: OFFSHORE TECHNOLOGY CONFERENCE, 2009, Houston. Proceedings... [S.1.:s.n.], 2009. (Paper OTC 19880).

BENGALY, A. P. Modelagem geométrica e termal tridimensional de corpos salíferos em bacias sedimentares. 2003. Dissertação (Mestrado) - Universidade Federal do Rio de Janeiro, Rio de Janeiro, 2003.

BORGES, R. G. Avaliação numérica de perturbações de tensões associadas a estruturas salíferas e suas influências na estabilidade de poços. 2008. Dissertação (Mestrado) Universidade Federal do Rio de Janeiro / COPPE, Rio de Janeiro, 2008.

BOTELHO, F. V. C. Análise numérica do comportamento mecânico do sal em poços de petróleo. 2008. Dissertação (Mestrado) - Pontifícia Universidade Católica, Rio de Janeiro, 2008 .

BOURGOYNE JÚNIOR, A. T. et al. Casing design. In: _ . Applied drilling engineering. Richardson: Society Petroleum Engineers, 1986. p.300-350. (SPE Textbook Series, 2).

BRADLEY, W. B. Failure of inclined boreholes. Journal of Energy Resources Technology, v. 101, n. 4, p. 232-239, 1979.

CAENN, R.; CHILlingaR, G. V. Drilling fluids: state of the art. Journal of Petroleum Science and Engineering, v. 14, p. 221-230, 1996.

CAVALCANTE, A. D. S. Modelagem numérica de escavações de túneis em maciços evaporíticos. 2012. Dissertação (Mestrado) - Escola de Engenharia de São Carlos, Universidade de São Paulo, São Carlos, 2012.

CELESTINO, T. B.; TAGLiATELLA, E. P.; CUSTÓDIO, P. S. D. O Método dos elementos finitos aplicado a escavações profundas em rochas. In: SEMINÁRIO BRASILEIRO DO 
MÉTODO DOS ELEMENTOS FINITOS APLICADO À MECÂNICA DOS SOLOS, 10., 1974, Rio de Janeiro. Anais... Rio de Janeiro: UFRJ/COPPE, 1974. p.229-245.

CHEATHAM JÚNIOR, J. B.; MCEVER, J. W. Behavior of casing subjected to salt loading. Journal of Petroleum Technology, v.16, p.1069-1075, 1964.

CHEN, F. et al. Investigation on creep behavior of salt rock and creep pressure on oil casing in deep stratum. In: ISRM INTERNATIONAL SYMPOSIUM, 3., 2004. Kyoto.

Proceedings... [S.1.:s.n.], 2004.

CHILINGARIAN, G. V.; VORABUTR, P. Drilling and drilling fluids, developments in petroleum science 11. New York: Elsevier Science, 1981.

CHRISTANTE, L. Pré-sal: desafios científicos e ambientais. Unesp Ciência. São Paulo, 2009. Disponível em: $<$ http://www.unesp.br/aci_ses/revista_unespciencia/acervo/03/pre-saldesafios-cientificos-e-ambientais $>$. Acesso em: 20 jan. 2014.

COSTA, A. M. Uma Aplicação de métodos computacionais e princípios de mecânica das rochas no projeto e análise de escavações subterrâneas destinadas à mineração subterrânea. 1984. Tese (Doutorado) - Universidade Federal do Rio de Janeiro / Coppe, Rio de Janeiro, 1984.

COSTA, A. M.; GONÇALVES, C. J. C.; AMARAL, C.S. Simulação do comportamento do poço 6-RJS-457-RJ no trecho perfurado em zona de sal e dimensionamento dos revestimentos. Rio de Janeiro: PETROBRÁS, 1997. (Relatório PETROBRAS/CENPES/DIPREX/SEDEM-017).

COSTA, A. M.; POIATE JÚNIOR, E.; FALCÃO, J. L. Triaxial creep tests in salt - applied in drilling through thick salt layers in Campos basin - Brazil. International Society for Rock mechanics, v.9, n.1, p.14-24, 2005.

COSTI, F. Metodologia numérica aplicada a viscoelasticidade em polímeros. 2006. Dissertação (Mestrado) - Pontifícia Universidade Católica do Paraná, Curitiba, 2006.

CURTIS, R. Association of dolomite and anhydrite in the recent sediments of the Persian Gulf. Nature, v.197, p.6779-6800, 1963.

DARLEY, H. C. H.; GRAY, G. R. Composition and properties of drilling and completion fluids. $5^{\text {th }}$ ed. Hounston: Gulf, 1988.

FALCÃO, J. L. et al. Perfuração em formações salinas. Boletim Técnico da Produção de Petróleo, v.1, n.2, p.293-307, 2007.

FARMER, P. et al Exploring the subsalt. Oilfield Review, v.8, n.1, p.50-64, 1996.

FJAR, E. et al. Petroleum related rock mechanics. $2^{\text {nd }}$ ed. New York: Elsevier, 2008.

FRAYNE, M. A; MRAZ, D. Z. Calibration of a numerical model for different potash ores. In: INTERNATIONAL CONGRESS ON ROCK MECHANICS, 7., 1991, Aachen.

Proceedings... New York: CRC Press, 1991. 
FREITAS, J. T. R. Ciclos deposicionais evaporíticos da bacia de santos: uma análise cicloestratigráfica a partir de dados de 2 poços e de traços de sismica. 2006. Dissertação (Mestrado) - Universidade Federal do Rio Grande do Sul, Porto Alegre, 2006.

FREITAS, J. J. Validação de uma metodologia de ensaio de resistência ao cisalhamento para avaliação da aderência de interfaces revestimento metálico-bainha de cimento aplicada a poços de petróleo. 2007. Dissertação (Mestrado) - Universidade Federal do rio Grande do Norte, Natal, 2007.

GIAMBASTIANI, M. Comportamento dependente do tempo de rochas sulfáticas de anidrita e gipso. 2005. Tese (Doutorado) - Escola de Engenharia de São Carlos, Universidade de São Paulo, São Carlos, 2005.

GOODMAN, E. R. Introduction to rock mechanics. $2^{\text {nd }}$ ed. New York: Jonh Wiley, 1989.

GRAVINA, C. C. Simulação numérica do comportamento mecânico do sal em poços de petróleo. 1997. Dissertação (Mestrado) - Universidade Estadual de Campinas, Campinas, 1997.

GRAY, K. E.; PODNOS, E.; BECKER, E. Finite element studies of near-wellbore region during cementing operations: part I. In: SPE PRODUCTION AND OPERATIONS SYMPOSIUM HELD IN OKLAHOMA CITY, 2007, Oklahoma. Proceedings... [S.1.:s.n.], 2007. (Paper SPE 106998).

HAAS JÚNIOR, J. L. et al. Geology, mineralogy, and some geophysical and geomechanical properties of salt deposits. In: GEVANTMAN, 1.h. (Ed.) Physical properties data for rock salt. Washington: National Bureau of Standards, 1981. Cap. 1, p.3-44. (National Bureau of Standat Monography, 167).

JASTRZEBSKI, Z. D. The Nature and properties of engineering materials. $2^{\text {nd }}$ ed. New York: John Wiley, 1976.

JEREMIC, M. L. Rock mechanics in salt mining. Rotterdam: A.A. Balkema, 1994.

JIN, J.; CRISTESCU, N. D. An Elastic/viscoplastic model for transient creep of rock salt. International Journal of Plasticity, v.14, n.1-3, p.85-107, 1998.

KIRSCH, G. Die theorie der elastizität und die bedürfnisse der festigkeitslehre. Zeitschrift des Vereines Deutscher Ingenieure, v.42, n.29, p.797-807, 1898.

LOMENICK, T. F. Project salt vault: a demonstration of the disposal of high- activity solidified wastes in underground salt mines. [S.1.:s.n.], 1971. (ORNL-4555).

MACHADO, J. C. V. Reologia e escoamento de fluidos. Rio de Janeiro: Interciência, 2002.

MACKAY, F. Análise geomecânica na perfuração e cimentação de poços de petróleo em zonas de sal. 2011. Tese (Doutorado) - Pontifícia Universidade Católica, Rio de Janeiro, 2011. 
MACKAY, F. et al. Análise do comportamento de evaporitos. In: PDPETRO, 4., 2007, Campinas. Anais... [S.1.]: ABPG, 2007. (4PDPETRO_2_2_0332-1-1).

MACKAY, F.; INOUE, N.; BOTELHO, F. Analyzing geomechanical effects while drilling sub salt wells through numerical modeling. In: SOCIETY OF PETROLEUM ENGINEERS, INDIAN OIL AND GAS TECHNICAL CONFERENCE AND EXHIBITION, 2008, Mumbai. Proceedings... [S.1.:s.n.], 2008.

MARCUSSO, J. L. et al. Extended well-test and production pilot in the Tupi area: the planning phase. In: OFFSHORE TECHNOLOGY CONFERENCE, 2009, Houston. Proceedings... [S.1.:s.n.], 2009. (Paper OTC 19886).

MEDEIROS, F. A. S. Análise do comportamento de colunas de revestimento frente à movimentação do sal em poços de petróleo. 1999. Dissertação (Mestrado) - Pontíficia universidade Católica, Rio de Janeiro, 1999.

MELO, P. R. C; CARVALHO, R. S.; PINTO, D. C. Rochas minerais industriais: uso e especificações. parte 2 - rochas e minerais industriais:usos e especificações. Rio de Janeiro: Centro de Tecnologia Mineral; Ministério da Ciência e Tecnologia, 2008. Cap.25: Halita.

MILANI, E. J. et al. Petróleo na margem continental brasileira: geologia, exploração, resultados e perspectivas. Brazilian Journal of Geophysics, v.18, n.3, p.351-396, 2000.

MOHRIAK, W.; SZATMAN, P.; ANJOS, S. M. C. Sal: geologia e tectônica. exemplos de bacias brasileiras. São Paulo: Beca, 2008.

MORAIS, J. M. Petróleo em águas profundas : uma história tecnológica da Petrobras na exploração e produção offshore. Brasília: Ipea; Petrobras, 2013.

MUNSON, D. E.; DEVRIES, K. L. Development and validation of a predictive technology for creep closure of underground rooms in salt. In: INTERNATIONAL CONGRESS ON ROCK MECHANICS, 7., 1991, Aachen. Proceedings... New York: CRC Press, 1991. v.1, p.127-134.

NELSON, E. B. Well cementing. $2^{\text {nd }}$ ed. Sugar Land: Schlumberger Educational, 1990.

OLIVEIRA, P. R. L. Análise não linear de deformação lenta utilizando o método dos elementos finitos. 2004. Dissertação (Mestrado) - Universidade Federal do Paraná, Curitiba, 2004.

OLIVEIRA, M. Novos desafios marinhos: a exploração de petróleo e gás abaixo da camada de sal no mar gera demanda de conhecimento e tecnologia. Pesquisa FAPESP, Edição Impressa 152, 2008.

PANET, M. Time dependent deformations in underground works. In: ISRM CONGRESS, 4., 1979, Monteux. Proceedings... Rotterdam: A. A. Balkema; Swiss Society for Soil and Rock Mechanics, 1979. v.3, p.279-289.

PETROBRAS. 2009. Disponível em:<http://www.petrobras.com.br/pt/energia-etecnologia/fontes-de-energia/petroleo/presal>. Acesso em: 28 fev. 2012. 
POIATE JÚNIOR, E.; COSTA, A. M.; FALCÃO, J. L. Well design for drilling through thick evaporite layers in Santos Basin - Brazil. In: SPE ANNUAL DRILLING CONGERENCE, 2006, Miami. Proceedings... [S.1.:s.n.], 2006. (Paper SPE 99161).

POIATE JÚNIOR, E. Mecânica das rochas e mecânica computacional para projeto de poços de petróleo em zonas de sal. 2012. Tese (Doutorado) - Pontifícia Universidade Católica, Rio de Janeiro, 2012.

ROCHA, L. A. S.; AVEZEDO, C. T. Projetos de poços de petróleo: geopressões e assentamento de colunas de revestimento. Rio de Janeiro. Interciência; Petrobras, 2007.

SCHREIBER, B. C.; EL TABAKH, M. Deposition and early alteration of evaporates. International Association of Sedimentologists, Sedimentalogy, v.47, s.1, p.215-238, 2000.

SILVA, M. A. M.; SCHREIBER, B. C.; SANTOS, C. L. Evaporitos como recursos minerais. Brazilian Journal of Geophysics, v.18, n.3, p.337-350, 2000.

THOMAS, J. E. et al. Fundamentos de engenharia de petróleo. 2.ed. Rio de Janeiro: Interciência; Petrobras, 2004.

VLACHOU, P.; PIAU, J. The Influence of the shear field on the microstrutural and chemical evolution of an oil well cement slurry its rheometric impact. Cement and Concrete Research, v.27, n.6, p.869-881, 1997.

WARPINSKI, N. R.; SMIYH, M. B. Rock mechanics and fracture geometry. In: GUDLEY, J.L. et al. (Ed.). Recent advances in hydraulic fracturing. Richardson: Society of Petroleum Engineers, 1989. v.12, p. 57-80.

WARREN, J. K. Evaporites: sediments, resources and hydrocarbons. Berlin: Springer Verlag, 2006.

WEATHERBY, J. R.; MUNSON, D. E.; ARGÜELLO, J. G. Three-dimensional finite element simulation of creep deformation in rock salt. Engineering Computations, v.13, n.8, p.82-105, 1996. 